\title{
Crystal forensics of historical lava flows from Mt Ngauruhoe
}

Sophie Jan Barton

A thesis submitted in partial fulfilment of the degree of Masters of Science with Honours in Geology.

Victoria University of Wellington

2011 


\begin{abstract}
$\underline{\text { Abstract }}$
Mt Ngauruhoe is a $900 \mathrm{~m}$ high andesitic cone constructed over the last $2500 \mathrm{yr}$, and is the youngest cone of the Tongariro Massif. It was previously one of the most continuously active volcanoes in New Zealand, with ash eruptions having occurred every few years since written records for the volcano began in 1839. However, it has now been more than $30 \mathrm{yr}$ since the last eruption. Eruptions in 1870, 1949, 1954 and 1974-1975 were accompanied by lava and block-and-ash flows. Detailed sampling of these historical lava and block-and-ash flows was conducted, including sampling from seven different lava flows erupted over the period June-September 1954 to investigate changes in magma geochemistry and crystal populations over short timescales, and to enable observed changes to be related back to known eruption dates.

Mineral major and trace element chemistry highlights the importance of mixing between distinct basaltic and dacitic melts to generate the basaltic andesite whole rock compositions erupted. The basaltic end member can be identified from the presence of olivine crystals with Mg\# 75-87, clinopyroxene cores with Mg\# 82-92, and plagioclase cores of $\mathrm{An}_{80-90}$. The dacitic melt is identified by $\mathrm{SiO}_{2}$-rich clinopyroxene melt inclusions, clinopyroxene zoning with $\mathrm{Mg} \#$ 68-76 and plagioclase rims of $\mathrm{An}_{60-70}$. Textural evidence from complex mineral zoning and large variability in the widths of reaction rims on olivine crystals suggests that mafic recharge of the more evolved system is frequent, and modelling of Fe-Mg inter-diffusion applied to the outermost rims of the clinopyroxene crystal population indicates that such recharge events have occurred weeks to months or even shorter prior to each of the historical eruptions, and thus likely trigger the eruptions.
\end{abstract}




\section{TABLE OF CONTENTS}

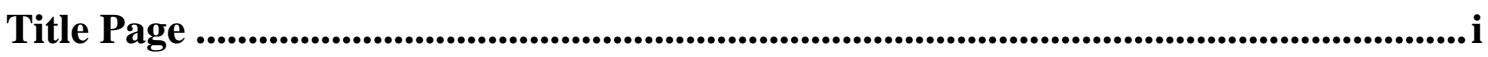

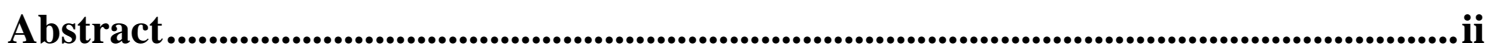

Table of Contents ............................................................................................................ii

List of Figures ................................................................................................................... vi

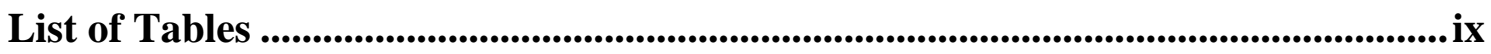

Acknowledgements...............................................................................................................

CHAPTER ONE: Introduction ........................................................................1

CHAPTER TWO: Fieldwork and Petrology...................................................... 22

CHAPTER THREE: Mineral chemistry and diffusion modelling results ..............54

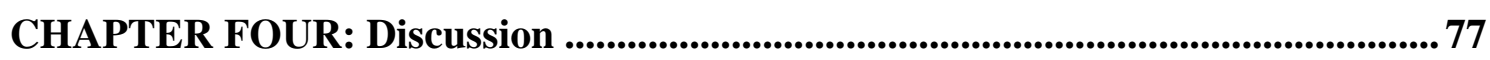

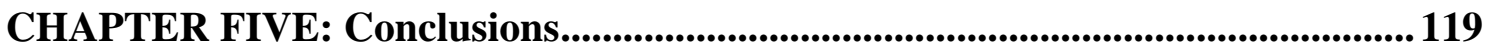

References ................................................................................................................ 12

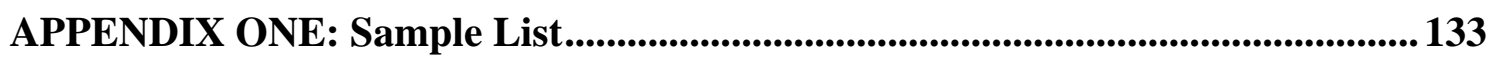

APPENDIX TWO: Analytical Methods .................................................................. 135

APPENDIX THREE: EPMA and LA-ICP-MS Data ........................................ CD

APPENDIX FOUR: Geothermometry _........................................................ 151

APPENDIX FIVE: Diffusion Modelling ................................................................ 159 


\section{CHAPTER ONE: INTRODUCTION}

1.1 Objectives of this thesis............................................................................... 2

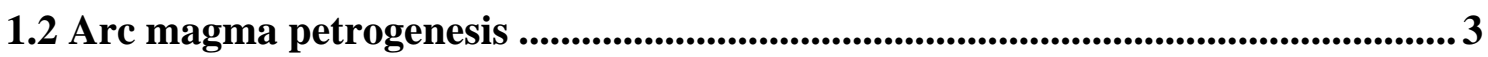

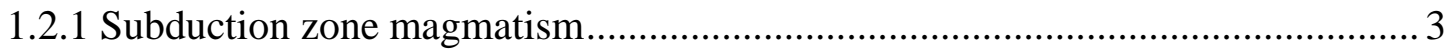

1.2.2 Crystals as archives of magmatic processes ............................................... 6

1.2.3 Constraining the timescales of magmatic processes using diffusion modelling .. 8

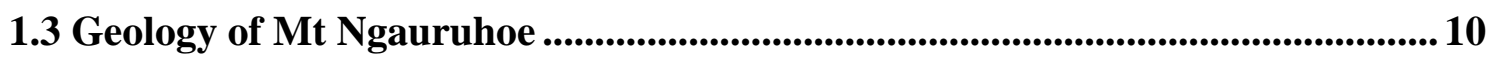

1.3.1 The Taupo Volcanic Zone and the Tongariro Massif ...................................... 10

1.3.2 Early eruptive history of Ngauruhoe ........................................................... 14

1.3.3 Historical eruptions and current understanding of Ngauruhoe......................... 17

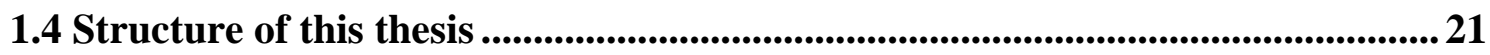

\section{CHAPTER TWO: FIELDWORK AND PETROLOGY}

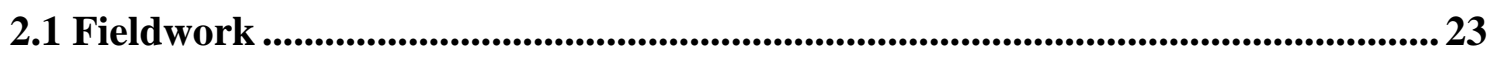

2.2 General petrology of the historical lava flows ........................................................... 24

2.3 Petrological features of the mineral populations....................................................... 29

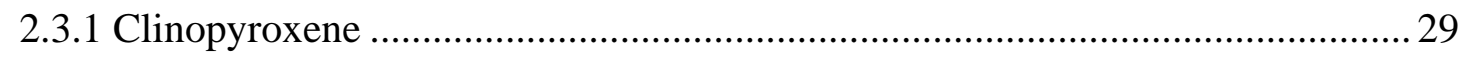

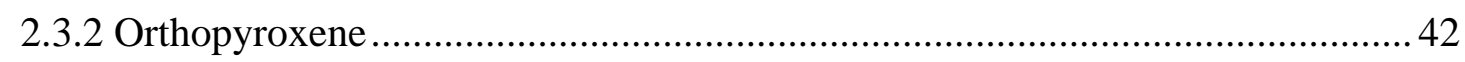

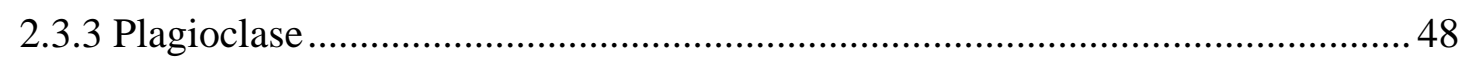

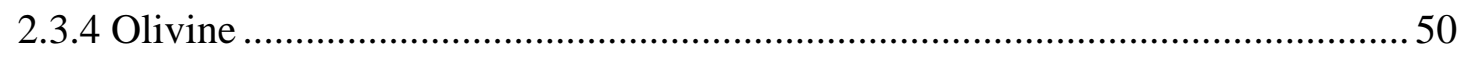

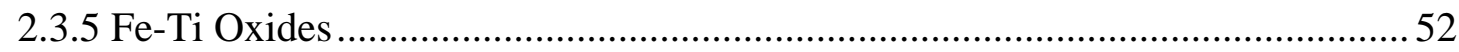

\section{CHAPTER THREE: MINERAL CHEMISTRY}

3.1 Mineral major element chemistry .................................................................................... 55

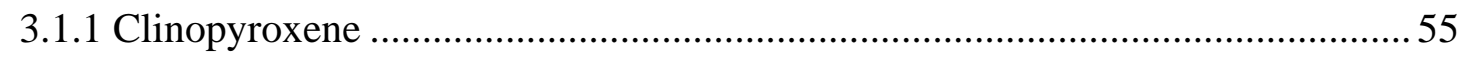

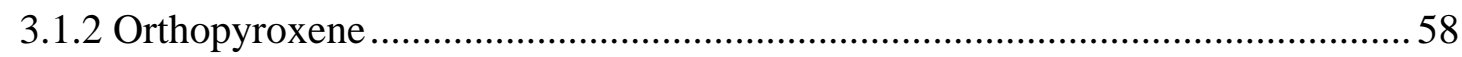

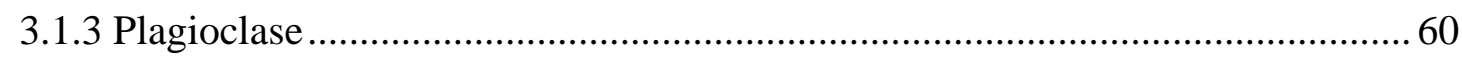

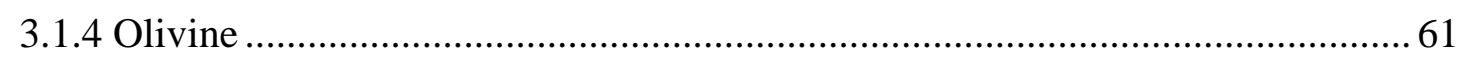

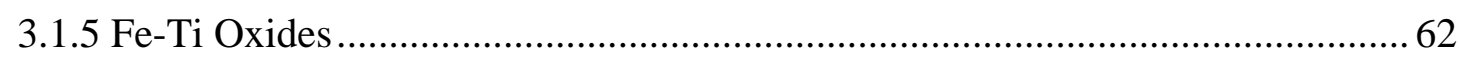

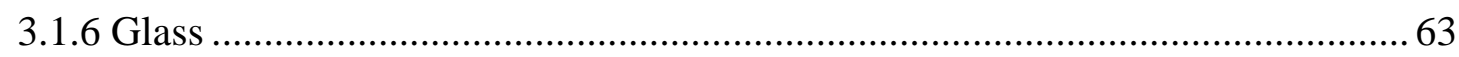

3.2 Mineral minor and trace element chemistry ............................................................... 68

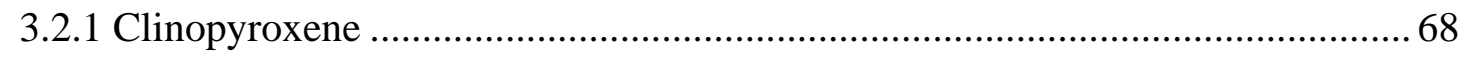

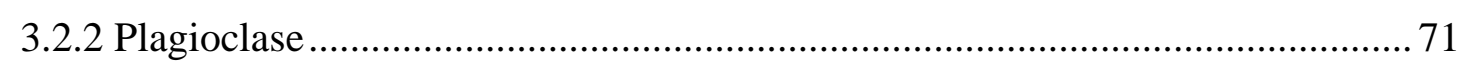

3.3 Diffusion modelling results...................................................................... 72 


\section{CHAPTER FOUR: DISCUSSION}

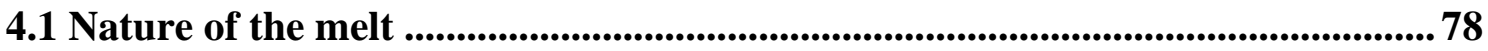

4.2 Origins of the crystal population ........................................................................................ 85

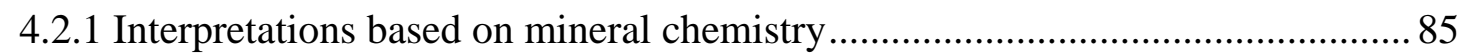

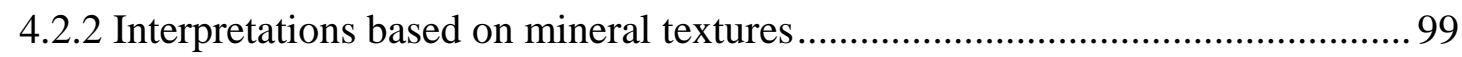

4.3 Temporal variability in the magma system .......................................................... 114

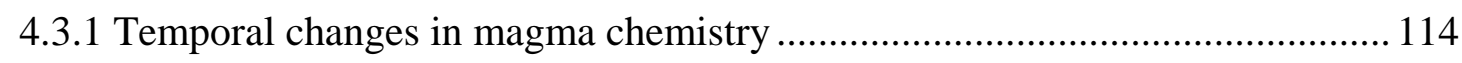

4.3.2 Temporal information from diffusion modelling ........................................ 115

\section{CHAPTER FIVE: CONCLUSIONS}

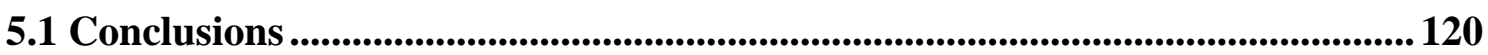

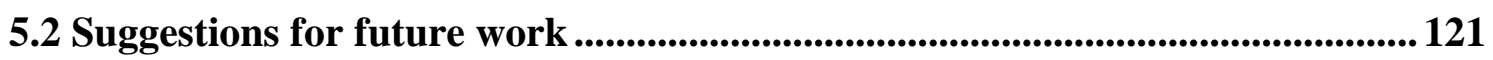

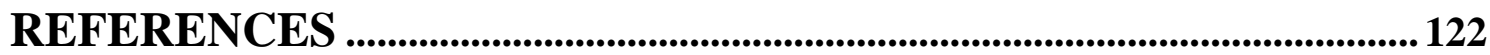

\section{SUPPLEMENTARY INFORMATION}

APPENDIX ONE: SAMPLE LIST ............................................................................... 133

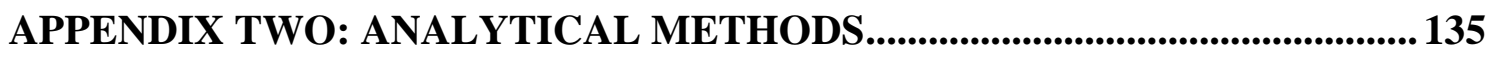

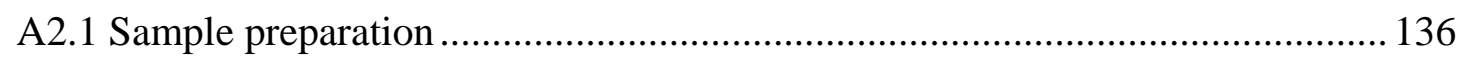

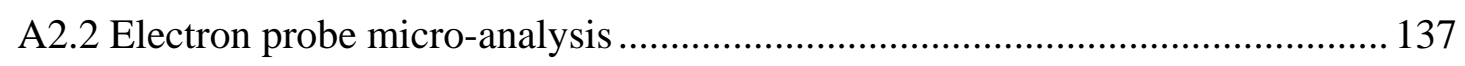

A2.3 Laser ablation inductively coupled plasma mass spectrometry........................ 141

APPENDIX THREE: EPMA AND LA-ICP-MS DATA ...................................... CD

APPENDIX FOUR: GEOTHERMOMETRY ...................................................... 151

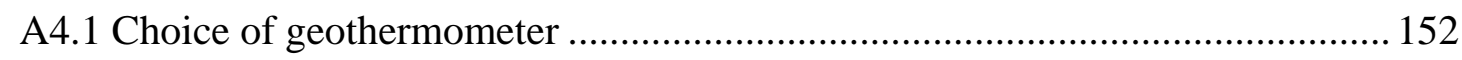

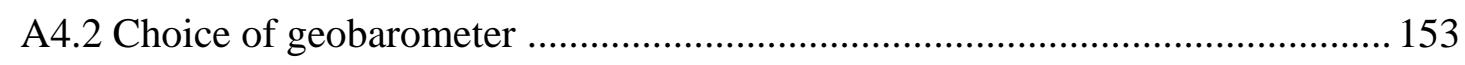

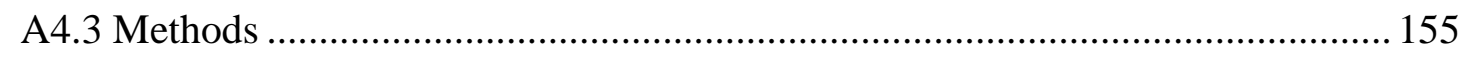

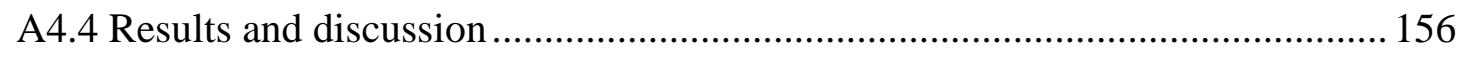

APPENDIX FIVE: DIFFUSION MODELLING .................................................... 159

A5.1 Diffusion in crystals and its value for obtaining timescales ............................ 160

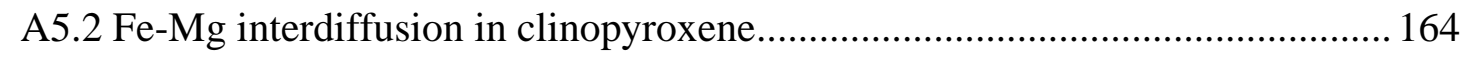

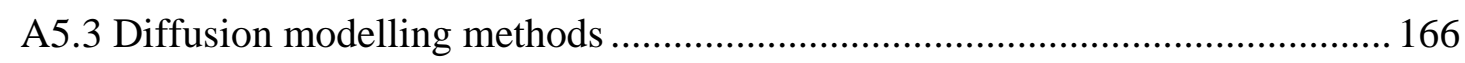




\section{LIST OF FIGURES}

\section{CHAPTER ONE: INTRODUCTION}

1.1: Simplified diagram of the Pacific-Australian subduction zone beneath New Zealand 4

1.2: Total alkalis silica diagram of arc volcanism 5

1.3: Back-scattered electron image of a polished section of sample SB48 7

1.4: Schematic diagram illustrating how an originally sharp compositional boundary in a crystal degrades over time due to diffusion.

1.5: Map of the North Island of New Zealand showing the location of Mt Ngauruhoe, the Taupo Volcanic Zone, and the locations and relative motions of the Pacific and Australian Plates.

1.6: Simplified geological map of the Tongariro Volcanic Centre. 13

1.7: Photographs showing the Mangatwai Tephra (Ngauruhoe)

1.8: Diagram showing changes in whole rock $\mathrm{MgO},{ }^{87} \mathrm{Sr} /{ }^{86} \mathrm{Sr}$ and $\mathrm{SiO}_{2}$ through time for the exposed Ngauruhoe lava flows

1.9: Total alkalis silica classification diagram for whole rock analyses of Tongariro and Ngauruhoe lava flows

1.10: Map of the Ngauruhoe lava flows from Battey (1949) with accompanying photograph of the 1870 lava flows as seen from the Mangatepopo Valley....

1.11: Photographs from Cloud (1951) of the 1949 lava flow shortly after its emplacement

1.12: Map from Hobden et al. (2002) showing the locations and dates of eruption of the historical Ngauruhoe lava and block-and-ash flows, in particular the different extents and locations of the 1954 flows

\section{CHAPTER TWO: FIELDWORK AND PETROLOGY}

2.1 Simplified map of the Ngauruhoe lava flows to show the locations of samples used in this study.....

2.2 Photomicrographs of xenoliths from the historical lava flows

2.3 Back-scattered electron (BSE) images of groundmass of the historical lava flows

2.4 Plane light images of thin sections to show the difference in average crystal size between the pre-historical and historical lava flows. 28

2.5 BSE images of clinopyroxene crystals from the 1870 lava flow 30

2.6 BSE images of clinopyroxene crystals from the 1949 lava flow 31

2.7 BSE images of clinopyroxene crystals from the $4^{\text {th }}$ June 1954 lava flow................. 32

2.8 BSE images of clinopyroxene crystals from the $30^{\text {th }}$ June 1954 lava flow................ 34

2.9 BSE images of clinopyroxene crystals from the $14^{\text {th }}$ July 1954 lava flow ............... 35 
2.10 BSE images of clinopyroxene crystals from the $29^{\text {th }}$ July 1954 lava flow 36

2.11 BSE images of clinopyroxene crystals from the $18^{\text {th }}$ August 1954 lava flow ........ 37

2.12 BSE images of clinopyroxene crystals from the $16^{\text {th }}$ September 1954 lava flow ... 39

2.13 BSE images of clinopyroxene crystals from the $18^{\text {th }}$ September lava flow ............ 40

2.14 BSE images of clinopyroxene crystals from the 1975 block-and-ash flow ............ 41

2.15 BSE images of orthopyroxene crystals that exhibit a relatively simple zoning pattern common in the lava flows

2.16 BSE images of orthopyroxene crystals that have thin, particularly Fe-rich rims ... 45

2.17 BSE images of orthopyroxene crystals that show a dissolution texture at the rim.46

2.18 BSE images of orthopyroxene crystals that have restricted Mg\# ......................... 47

2.19 BSE images of orthopyroxene crystals showing anomalous Fe-rich cores ............ 47

2.20 BSE images of plagioclase crystals to illustrate the range of textures that occur... 49

2.21 BSE images and cross-polarised photomicrographs of olivine crystals 51

2.22 BSE images of opaque minerals (titanomagnetite, iron sulphide, chromium spinel, ilmenite, magnetite and hercynitic spinel) 53

\section{CHAPTER THREE: GEOCHEMISTRY AND DIFFUSION MODELLING RESULTS}

3.1: Pyroxene quadrilateral diagram showing the range in chemistry of clinopyroxene and orthopyroxene phenocrysts and antecrysts

3.2: Histogram showing the maximum range in $\mathrm{Mg} \#$ for individual clinopyroxene crystals

3.3: Histograms of clinopyroxene Mg\# separated by lava flow

3.4: Histograms of orthopyroxene Mg\# separated by lava flow 59

3.5: Histogram of plagioclase anorthite content for all historical lava flows, showing differences between cores, rims, and other zoning

3.6: Graph comparing anorthite content of plagioclase cores and rims between the historical lava flows

3.7: Graph comparing Mg\# of olivine cores between the historical lava flows

3.8: Graphs showing weight percent $\mathrm{MgO}$ and $\mathrm{Al}_{2} \mathrm{O}_{3}$ versus. $\mathrm{X}^{\prime} \mathrm{Usp}$ of the Fe-Ti oxide crystal population

3.9: Total alkalis silica diagrams of analyses of groundmass glass and clinopyroxene melt inclusions

3.10: Graphs of element oxides versus $\mathrm{SiO}_{2} \mathrm{wt} \%$ for analyses of groundmass glass .... 66

3.11: Graphs of element oxides versus $\mathrm{SiO}_{2} \mathrm{wt} \%$ for analyses of clinopyroxene melt inclusions

3.12: Graphs of clinopyroxene minor and trace element data 
3.13: Chondrite-normalised rare earth element plots of clinopyroxene analyses .70

3.14: Graphs of selected plagioclase trace element data.

3.15: Probability density function curves for the ages obtained by diffusion modelling for the outermost rims of the clinopyroxene crystal population .....

3.16: Probability density function curves for the ages obtained by diffusion modelling for cores of the clinopyroxene crystal population 76

\section{CHAPTER FOUR: DISCUSSION}

4.1 Back-scattered electron images comparing the groundmass of the 1870 and $30^{\text {th }}$ June 1954 lava flows

4.2 Graph of melt inclusion $\mathrm{SiO} 2$ versus whole-rock SiO2 for North, Central and South American volcanic arc rocks, with Ngauruhoe data added. 84

4.3 Diagram from Reubi and Blundy (2009) showing experimental liquid lines of descent of melts for different pressures and starting compositions

4.4 Diagram comparing the range in Mg\# and anorthite of the Ngauruhoe crystal populations with those of basalts and rhyolites from the Taupo Volcanic Zone .87

4.5 Histogram of Mg\# of all Ngauruhoe clinopyroxene analyses

4.6 Fractional crystallisation modelling using $\mathrm{Cr}$ measured in clinopyroxene. 88

4.7 Fractional crystallisation and mixing modelling using $\mathrm{Sr} / \mathrm{Nd}$ measured in clinopyroxene..... 91

4.8 Images of thin, calcic outermost rims on plagioclase crystals 96

4.9 Comparison of Ngauruhoe orthopyroxene texture to one from Whaleback Volcano, California 102

4.10 Back-scattered electron images of plagioclase crystals showing patchy and sieved cores and zoning...... 106

4.11 Back-scattered electron images of plagioclase oscillatory zoning and resorption features in rims 108

4.12 Back-scattered electron images of plagioclase crystals showing oscillatory zoning of the calcic cores.

4.13 Back-scattered electron images of olivine crystals from the 1949 lava flow 115

4.14 Images of two Mg-rich rims that were modelled, with diffusion profiles and ages for the boundaries.

\section{APPENDIX FOUR: GEOTHERMOMETRY}

A4.1 Diagrams from Putirka (2008) comparing the differences between experimentally measured temperatures/pressures and those returned from three different geothermometers and one geobarometer 155 


\section{APPENDIX FIVE: DIFFUSION MODELLING}

A5.1 Diagram from Watson and Baxter (2007) to show some of the ways in which diffusion of atoms may take place through a solid crystal lattice

A5.2 Diagram showing a set of error function curves to demonstrate their use for diffusion modelling

\section{LIST OF TABLES}

\section{CHAPTER ONE: INTRODUCTION}

1.1: Summary of the main historical eruptions from Mt Ngauruhoe.

\section{CHAPTER FOUR: DISCUSSION}

4.1 Mixing modelling of mineral populations and groundmass glass 79,80

4.2 Mixing modelling of groundmass glass and microlites to estimate the composition of the final melt

\section{APPENDIX TWO: ANALYTICAL METHODS}

A2.1 Standards used for secondary normalisation of EPMA data.

A2.2 EPMA precision and accuracy of major element analyses (wt \%) of international glass and mineral standards. 139, 140

A2.3 Details of LA-ICP-MS conditions for clinopyroxene and plagioclase analysis .. 143

A2.4 Concentrations and standard errors calculated for analyses of the standard BCR$2 \mathrm{G}$ that were treated as unknowns

A2.5 Table showing the differences in concentrations of $\mathrm{Mg}$ and $\mathrm{Ba}$ obtained when measuring two different isotopes of the elements during the same spot analysis of a plagioclase sample

A2.6 GeoRem preferred values for element concentrations in standards used for calculation of trace element concentrations in samples following LA-ICP-MS analysis

\section{APPENDIX THREE: EPMA AND LA-ICP-MS DATA TABLES}

A3.1 Clinopyroxene major element data

A3.2 Orthopyroxene major element data

A3.3 Plagioclase major element data

A3.4 Olivine major element data

A3.5 Fe-Ti oxide major element data

A3.6 Groundmass glass major element data

A3.7 Clinopyroxene melt inclusion major element data.

A3. Clinopyroxene trace element data 


\section{APPENDIX FOUR: GEOTHERMOMETRY}

A4.1 Results obtained from the two-pyroxene geothermometers of Putirka (2008) and Brey \& Kohler (1990) for the historical Ngauruhoe lava flows

A4.2 Results obtained from pyroxene-melt geothermometers and one clinopyroxene only geothermometer for those lava flows for which major element groundmass glass data was obtained

A4.3 Results obtained from plagioclase-melt geothermometers for those lava flows for which major element groundmass glass data was obtained

\section{APPENDIX FIVE: DIFFUSION MODELLING}

A5.1 Comparison of timescales obtained for different sections of the same boundary 167

A5.2 Comparison of timescales obtained for models of the same boundary using images taken on the JEOL-733 Superprobe with those taken on the JEOL-JXA 8230

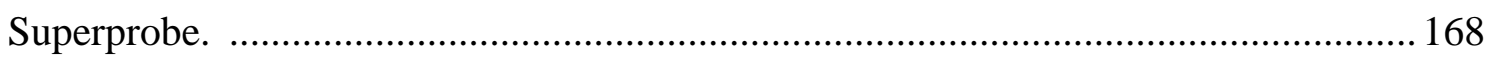

A5.3 Calculations of the effects of image convolution at different magnifications ..... 170

\section{LIST OF PLATES}

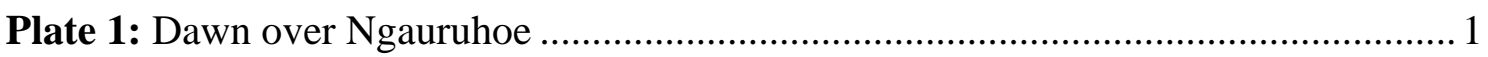

Plate 2: The $18^{\text {th }}$ August 1954 lava flow viewed from Pukekaikiore ............................. 22

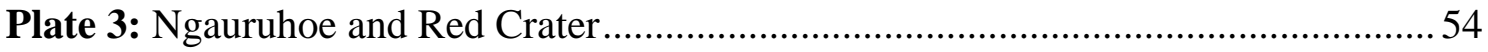

Plate 4: View of Mt Ngauruhoe from the Mangatepopo Valley .................................. 77

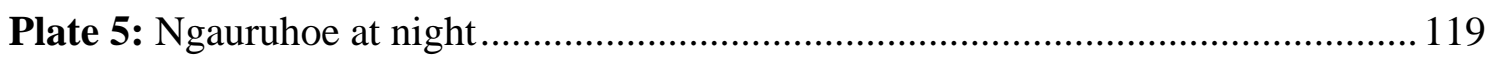

List of Figures $\quad$ X 


\section{ACKNOWLEDGEMENTS}

I would like to especially thank my supervisor, Joel Baker, for his patient guidance and assistance throughout this project, and for the speed with which he provided edits and feedback during the final stages. Also Kate Saunders for helping to set up the project and proof-reading and providing thoughtful feedback, ideas and encouragement, and Dan Morgan, who ran workshops on diffusion modelling, provided spreadsheets to use, and was always willing to help with any issues, going out of his way to provide additional assistance and encouragement.

Many thanks also to my fieldwork team: Richard Wysoczanski, Joel Baker, Alex McCoy-West, Sarah Martin, Nicole Semple and Marc-Alban Millet, who drove long distances and hiked a mountain carrying rocks and sledge-hammers to allow this project to happen.

My sincere thanks to the many people who helped with the data gathering and interpretation stages: Stewart Bush, who prepared all thin and thick sections and assisted with use of the rock saws. John Patterson and John Creech who patiently trained me up on how use the two different probes, and came in at odd hours and weekends to fix problems and change filaments. MarcAlban Millet for help with use of the LA-ICP-MS, and with data processing and analytical techniques in general. Julie Vry for assisting with use of the rock crusher, microscopy, and for always being happy to help with a question or lend out a book. Jill Ruthven, our geology department librarian who was always willing to assist with locating journals, using new software, and even promptly answered any questions following retirement! To the many other who have given help and advice with interpretations of data, including Colin Wilson, Monica Handler, Aidan Allan, and Richard Wysoczanski.

I am grateful for the financial support provided by a Victoria University of Wellington graduate award, and also to the Department of Conservation for allowing the collection of samples without which this project could not have taken place.

I would also like to especially thank Sarah Martin, who was beside me to offer advice and support throughout all stages of this thesis: problem-solving issues with lab-work and spreadsheets, working together to understand concepts and interpret findings, suggesting papers, and commiserating with me over the less enjoyable tasks! I cannot thank her enough for her friendship and support. But a huge thank you also to the many who have provided much friendship, assistance and support along the way: Chelsea, Jess, Lou, Nicole, Kirsty, George, Andy, Jai, Alex, Melissa, Alexa, Susan, Caitlin, Sarah Ramsay, and many more. Also to my workmates Adele Hogan, Melissa Lacascade, \& Mel White who covered extra shifts for me during the final stages, often at short notice.

My parents, Hez \& John, are thanked for not only their love, friendship and financial support, but for proof-reading most of the thesis for me, along with my aunty Ellie. My siblings, Amy, Ralph, \& Richard, and niece Ana, are thanked for their endless love \& support, and for providing much needed down time. And lastly I would like to thank Gareth, whose selflessness, friendship, love, support and encouragement I simply could not have done without. 


\section{CHAPTER ONE: INTRODUCTION}

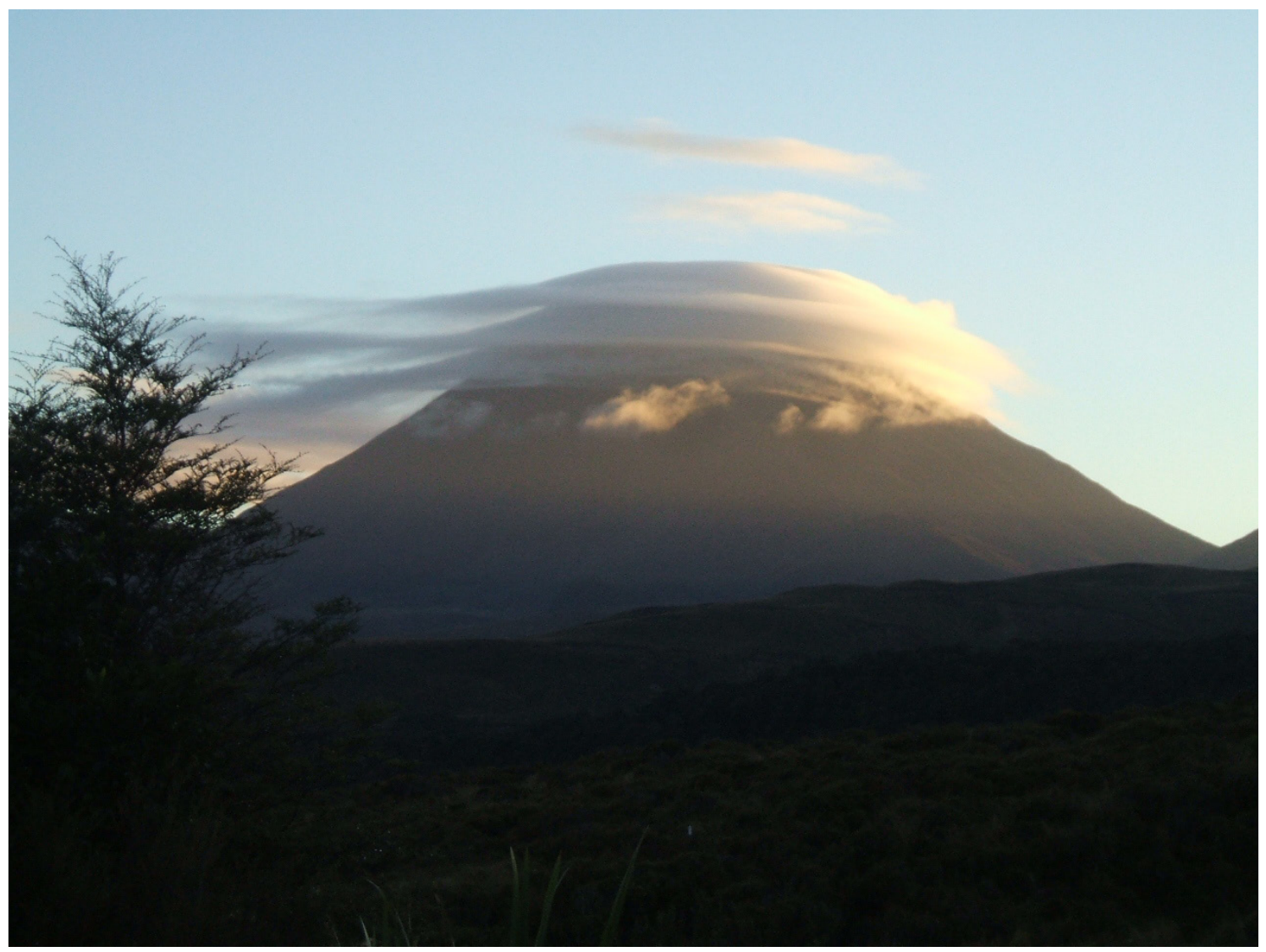

Plate 1: Dawn over Mt Ngauruhoe 


\subsection{Objectives of this thesis}

The objectives of this thesis are to combine detailed petrographic investigations with crystal-specific in situ geochemical measurements of the historical Ngauruhoe lava flows in order to gain insight into the magma system and pre-eruptive processes occurring at the volcano. Diffusion modelling of compositional boundaries in the crystal population is applied to obtain timescales of magmatic processes occurring in the lead up to eruptions where appropriate.

Specifically this study seeks to:

1) Investigate and interpret in detail the petrology of the historical Ngauruhoe lava flows.

2) Use electron probe microanalysis (EPMA) to measure the major element geochemistry of the crystal population (clinopyroxene, orthopyroxene, plagioclase, olivine, Fe-Ti oxides) and clinopyroxene-hosted melt inclusions to better understand the plumbing system and magmatic processes beneath Ngauruhoe.

3) Couple clinopyroxene and plagioclase major element measurements with trace element data obtained via laser ablation inductively coupled plasma mass spectrometry (LA-ICP-MS) to place further constraint on the processes leading to the observed zoning.

4) Apply two-pyroxene geothermometry to each of the historic lava flows to calculate the temperature of the final batch of magma prior to eruption.

5) Constrain timescales for the most recent magmatic events recorded in the crystal population of the historical lava flows prior to their eruption.

6) Relate findings back to the known eruption dates for the lava flows to gain insight into the short-timescale processes occurring beneath the volcano. 


\subsection{Arc magma petrogenesis}

\subsubsection{Subduction zone magmatism}

Arc magmatism occurs at convergent plate margins where the oceanic lithosphere of one plate is being subducted beneath the continental or oceanic lithosphere of another plate (Figure 1.1). With the possible exception of adakites, primary magmas are considered to be generated from partial melting within the mantle wedge, the region of upper mantle beneath the overriding plate and overlying the oceanic lithosphere of the subducting plate (Gill, 1981). Partial melting results from lowering of the solidus by the addition of volatiles released from the subducting slab as it undergoes dehydration reactions during blueschist-eclogite facies metamorphism, although decompression melting from subduction-induced corner flow has also been suggested to be a possible mechanism for triggering melting (Wilson, 1989; Turner et al., 2000; Annen et al., 2006).

Typically, the volcanic arc forms $\sim 100-125 \mathrm{~km}$ above the top of the subducting plate (Gill, 1981; Tatsumi, 1986; England et al., 2004; Syracuse \& Abers, 2006). Previously it has been suggested that this distance to the top of the slab is relatively constant and is due to the depth at which hydrous minerals in the subducting slab break down and release volatiles (Tatsumi et al., 1983). Recent studies, however, indicate substantial variation in slab depth and suggest that other factors such as wedge thermal structure may be more important in determining the location of the volcanic arc than the depth at which the dehydration of hydrous phases takes place (Schmidt \& Poli, 1998; Kerrick \& Connolly, 2001, England et al., 2004; Syracuse \& Abers, 2006). 


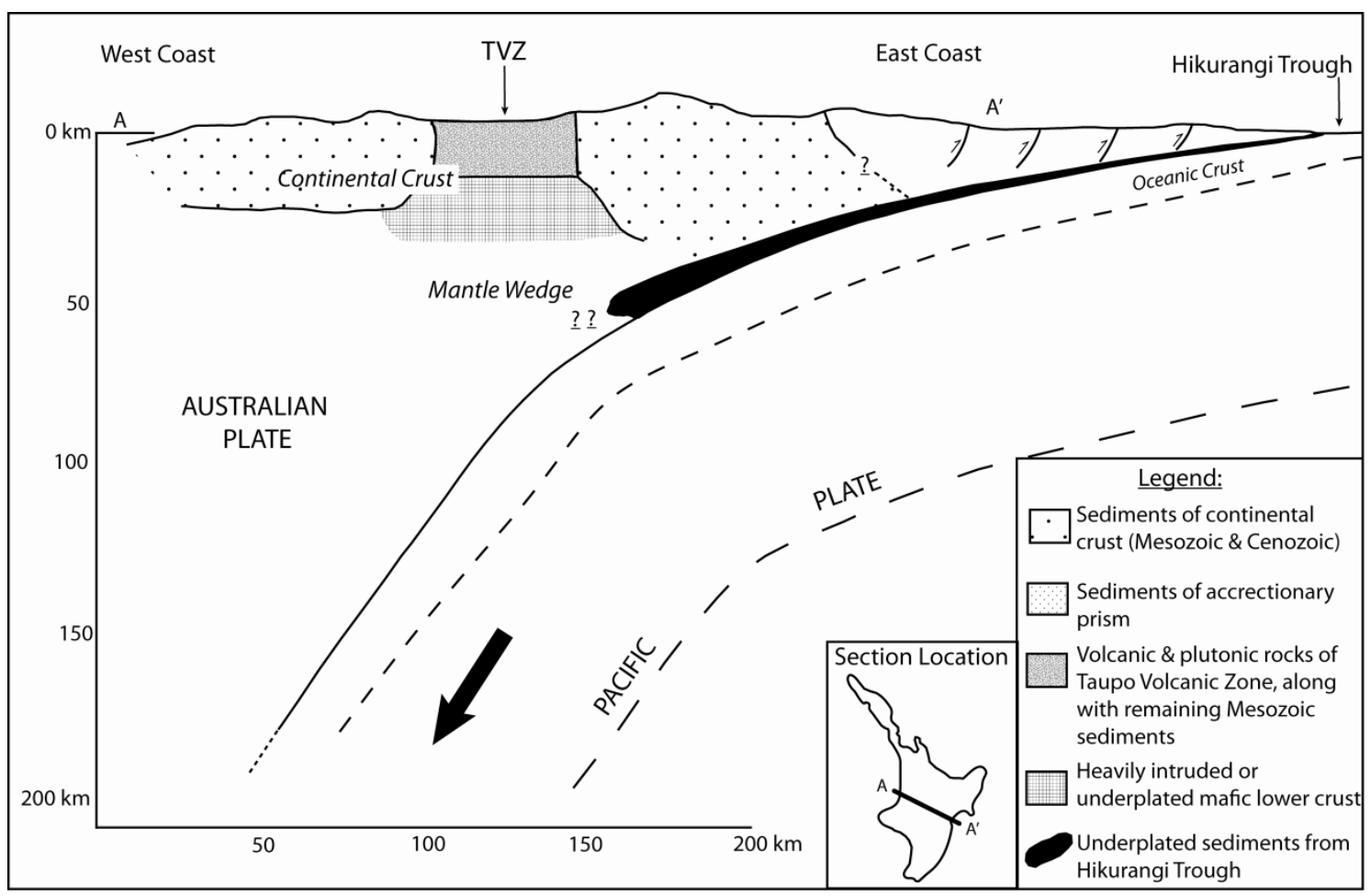

Figure 1.1: Simplified diagram of the Pacific-Australian subduction zone beneath New Zealand showing subduction of Pacific Plate and locations of mantle wedge, fore-arc region and Taupo Volcanic Zone (which encompasses both arc and back-arc volcanism). Modified from Cole (1990) and using interpretation of underplated or heavily intruded mafic lower crust from Harrison and White $(2004,2006)$.

Prior to eruption at the surface, magma in continental arc settings must ascend through the continental lithosphere. The low density of the continental crust may retard ascent of the magma, allowing it to be modified by a range of physical and chemical processes including decompression, heat transfer from igneous underplating, fractional crystallisation, crustal assimilation, mafic recharge, degassing, and magma mixing (Ruprecht \& Wörner, 2007; Streck, 2008). Mixing may occur between magmas which have differentiated/resided in different parts of the magmatic plumbing system or between different parts of the same magma chamber which have different temperatures and/or chemistry (Streck, 2008).

Whilst basaltic andesite to andesitic volcanism is dominant in volcanic arcs, in many cases it is associated with equal or greater quantities of basalt, rhyolite, or dacite (Carmichael et al., 1974; Figure 1.2). Young oceanic arcs tend to be associated with tholeiitic magmas, whereas calc-alkaline magmas are dominant in mature oceanic arcs and continental arc settings (Miyashiro, 1974). Arc rocks typically show enrichment in 
the large ion lithophile elements, which has been attributed to metasomatism of the source mantle by fluids released from the subducting slab, and are characterised by flat chondrite-normalised middle to heavy rare earth element profiles implying a shallow (spinel lherzolite) mantle source (Wilson, 1989; McCulloch \& Gamble, 1991; Murphy, 2007). Variations in chemistry, temperature and dissolved $\mathrm{H}_{2} \mathrm{O}$ contents can occur along an arc. For example, Annen et al. (2006) noted how there may be a range from dry and hot magmas to wet and cool magmas within the one arc, and Philpotts (1990) noted a change in the Lesser Antilles from tholeiitic magmatism in the north to alkaline in the south.

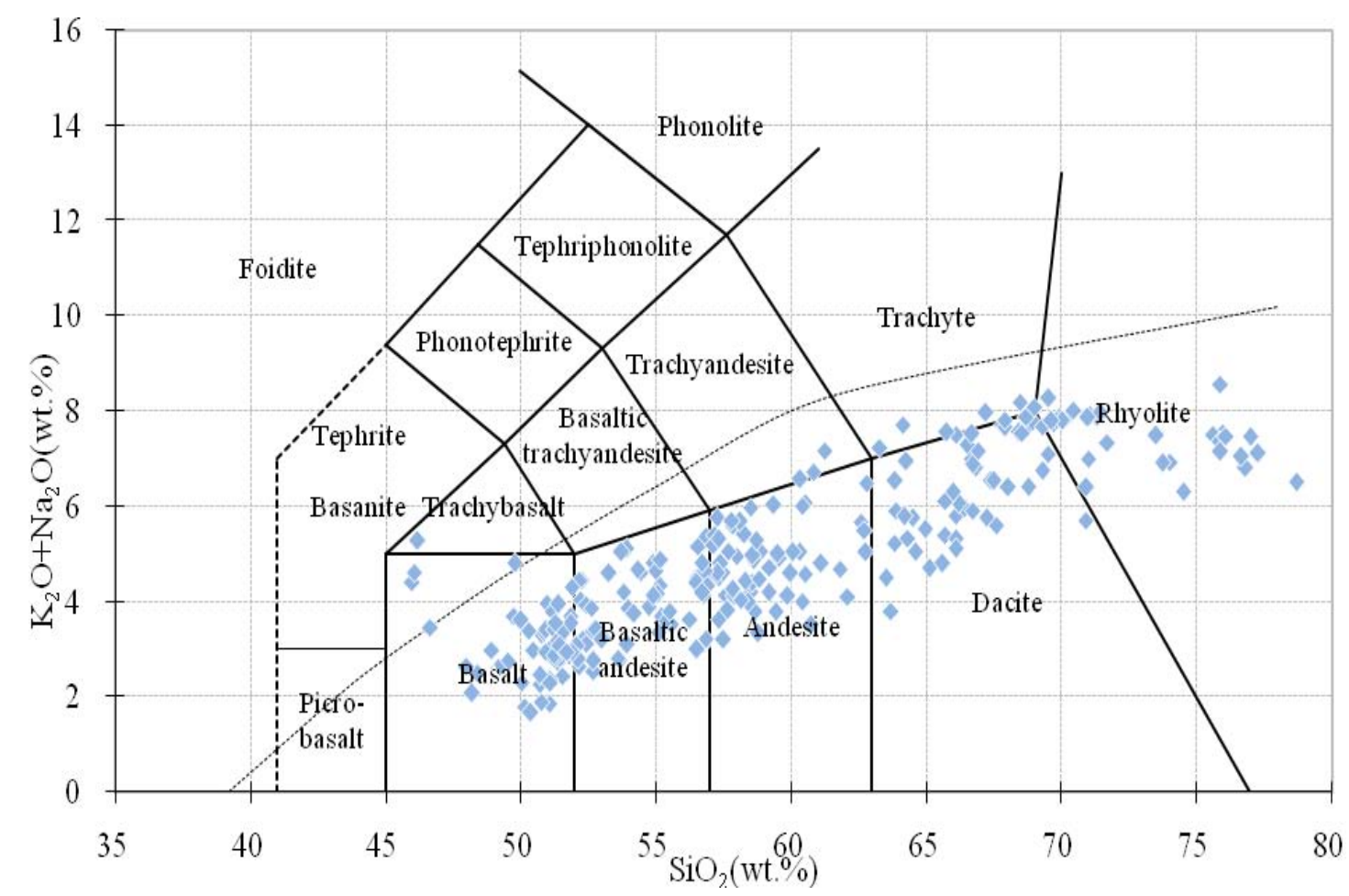

Figure 1.2: TAS diagram of arc volcanism compiled using subsets of whole-rock data sourced from the GEOROC database for the Cascadian, New Zealand, Honshu, Andean, and Aleutian arcs.

Despite the abundance of andesitic bulk rock compositions in arc settings, recent studies suggest a pronounced lack of corresponding melts of andesitic composition. Experimental crystallisation work by Reubi and Blundy (2009) combined with melt inclusion and whole-rock geochemical data suggests a compositional bimodality of melts reaching the upper crust, possibly resulting from the phase relations of hydrous basalts in the mid- to lower crust. Rocks with andesitic whole rock chemistry are therefore commonly highly porphyritic rocks composed of predominantly mafic crystal 
cargoes hosted within dacitic to rhyolitic melts, rather than rocks which have crystallised from melts of true andesitic composition. This observation highlights the need to study porphyritic arc rocks by analysing the crystal population in more detail rather than focusing on whole rock geochemical studies.

\subsubsection{Crystals as archives of magmatic processes}

Despite the complexity of arc systems and the range of processes which may occur prior to eruption of these magmas, they are particularly important to understand. In addition to their association with ore deposits (e.g. Beckinsale \& Mitchell, 1981), importance for models of the growth of continental crust (e.g. Taylor, 1967) and role as being the only site where surficial material is recycled back into the mantle, arc volcanoes are the second largest site of magma production globally (Wilson, 1989). Eruptions from arc volcanoes can be particularly hazardous. For example, the eruptions of Krakatau in 1883 and Mt Pelée in 1902 resulted in thousands of fatalities due to the associated tsunami and pyroclastic flows (Symons, 1888; Heilprin, 1903). It is hoped that improved understanding of the processes involved in subduction zone volcanism will lead to improved monitoring systems and risk assessment of active volcanoes.

Textural characteristics of volcanic rocks and their crystal populations such as crystal size and abundance, crystal zoning patterns, dissolution features and reaction rims can provide information about the magmatic history and pre-eruptive conditions (Davidson et al., 2001; Ginibre et al., 2007; Streck, 2008). Linking these textural features with in situ major and trace element chemistry can place further constraints on the magmatic environment prior to eruption and aid in the identification of different crystal populations present within a single lava flow (Streck, 2008). Along with the phenocrysts and microlites which have crystallised directly from the magma and are in equilibrium with the surrounding glass, the crystal population of a volcanic rock may include abundant antecrysts and xenocrysts (Figure 1.3). Antecrysts are crystals that have formed within the same magma system but been stored in crystal accumulations or recycled through multiple recharge events prior to their eventual eruption, whilst 
xenocrysts are those foreign to the magma system that have been incorporated from country or wall rock (Jerram \& Martin, 2008).

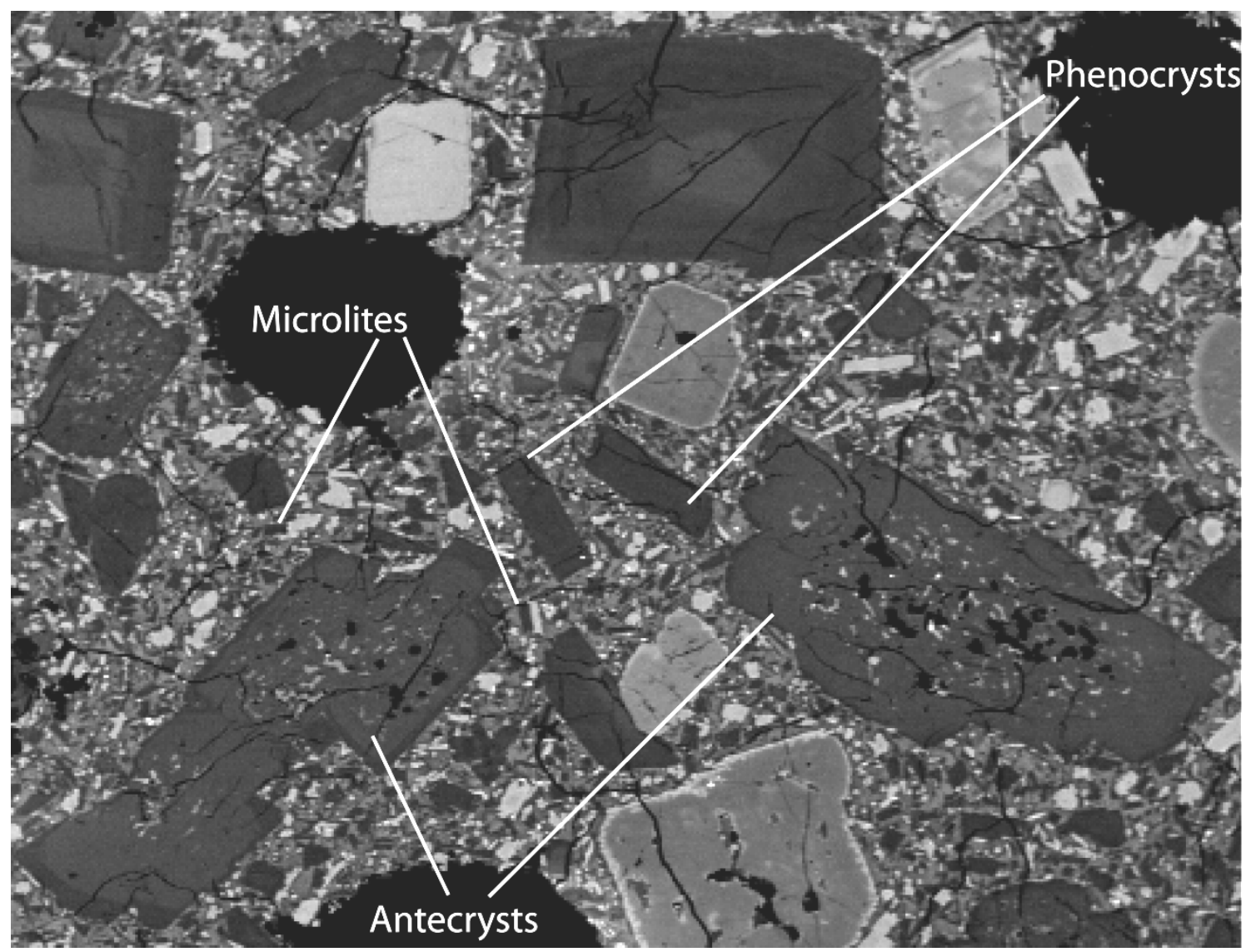

Figure 1.3: Back-scattered electron image of a polished section of sample SB48 (the $18^{\text {th }}$ September 1954 lava flow from Ngauruhoe), showing plagioclase microlites in the groundmass, possible phenocrysts with near-uniform composition similar to that of the microlites, and antecrysts (or possibly xenocrysts) with distinctly more anorthitic core compositions and sieve texturing. Light grey crystals are pyroxenes.

Since the outermost portion of a crystal is in equilibrium with the surrounding melt from which it is crystallized, the compositional zoning in minerals will reflect temporal changes in the evolution of the magmatic environment. These may be chemical changes such as magma recharge, mixing or assimilation, or changes in physical parameters such as temperature, pressure or oxygen fugacity (Ginibre et al., 2007; Streck, 2008). Correlating major element zoning with trace element measurements aids in distinguishing from within this range of possible causes. For example higher $\mathrm{Cr}$ concentrations coinciding with higher Mg regions of a pyroxene may indicate that the higher $\mathrm{Mg}$ regions are the result of growth from a more mafic melt as opposed to a higher oxygen fugacity (Streck, 2008). Textural zoning in antecrysts has the potential to 
preserve a record of events in the evolution of the magma system as a whole, whereas phenocrysts record the history of only the last major batch of magma (Jerram \& Martin, 2008). Melt inclusions trapped during crystal growth may also act as a useful archive of changes in melt chemistry and volatile content during magma evolution, potentially providing a direct snapshot of the melt composition at the time of entrapment. However, melt inclusion analyses should be approached with caution due to the possibility of post-entrapment processes which may alter the chemistry, such as growth of the host crystal from the trapped melt, leakage of the inclusion, or diffusive exchange between the host and melt (Lowenstern, 2003). In addition, recent work indicates that water exchange may occur between melt inclusions and the host magma and that they are therefore not a reliable record of the volatile content at the time of entrapment (Portnyagin et al., 2008).

In situ geochemical techniques applied to crystal zoning and textures, melt inclusions and interstitial glass can thus provide information that cannot be obtained from wholerock analyses alone, which average and obscure this finer-scale detail of the petrological history of the rock to give only a bulk composition. The chemical and textural information preserved within the crystal population has the ability to record the major magmatic events that occur in the lead up to eruption, providing evidence to allow reconstruction of aspects of the sub-volcanic magmatic plumbing system.

\subsubsection{Constraining the timescales of magmatic processes using diffusion modelling}

Our understanding of the timing of processes that occur between partial melting of the mantle and the eruption of lavas at the surface is limited. Uranium-series disequilibrium dating has been applied to magmatic systems to calculate timescales for a range of magmatic processes, including magma storage, differentiation, crystallisation and degassing (Condomines et al., 2003). However, uranium-series techniques can be somewhat problematic, often relying on the assumption of closed-system evolution or assumptions about initial isotopic ratios. Recently, the experimental determination of diffusion coefficients for a range of elements in different minerals has allowed the modelling of diffusion across compositional boundaries in igneous crystals to be used as 
a new tool to investigate the timescales of magmatic processes (Chakraborty, 2008; Costa et al., 2008). Diffusion modelling has a number of advantages over uraniumseries techniques such as: (1) being unaffected by crustal assimilation and open system processes, (2) there not being a limit on the sample age that it is possible to calculate a timescale from (it is theoretically possible to obtain a timescale for a month-long event from a million year old rock), and (3) not necessarily requiring the process it dates to be one that resulted in the significant fractionation of isotopes.

Diffusion modelling is based on the fact that at magmatic temperatures diffusion of elements will smooth out an initially sharp compositional boundary at a rate dependent on the temperature and the diffusion coefficients of the elements of interest in that mineral (Zellmer et al., 1999; Costa et al., 2008; Figure 1.4). Thus, using experimentally determined diffusion coefficients coupled with temperatures obtained from geothermometry, profiles of element concentrations obtained perpendicular to compositional boundaries can be used to calculate the timescale over which the zones have existed at magmatic temperatures. For example, if mafic recharge causes a preexisting crystal to grow a more mafic rim, then the timescale calculated for the boundary between those two zones would represent the amount of time prior to eruption that renewed crystal growth occurred following the recharge event. Diffusion modelling therefore provides a tool to investigate the timescales of magmatic processes occurring in the lead up to a volcanic eruption. 
Schematic back-scattered electron image of crystal
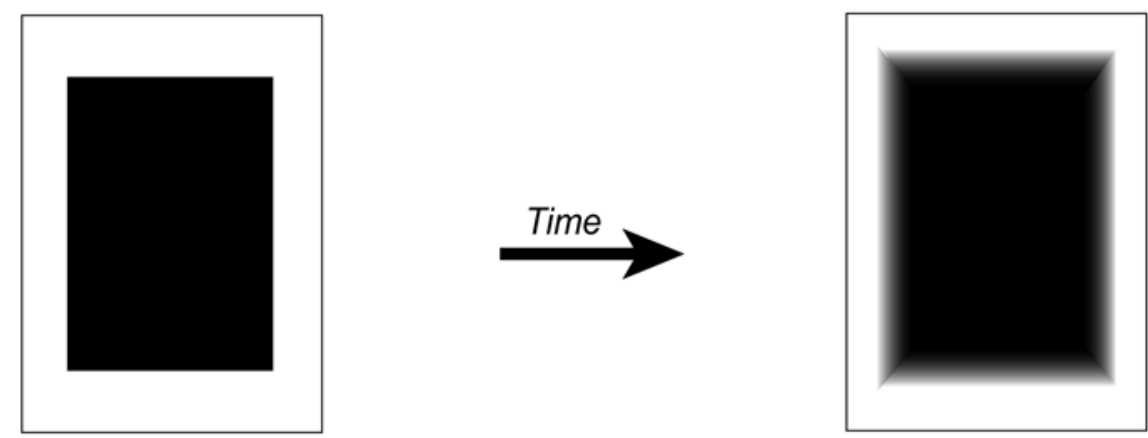

Graphs showing concentration of an element (e.g. Fe in clinopyroxene) across a transect of the crystal
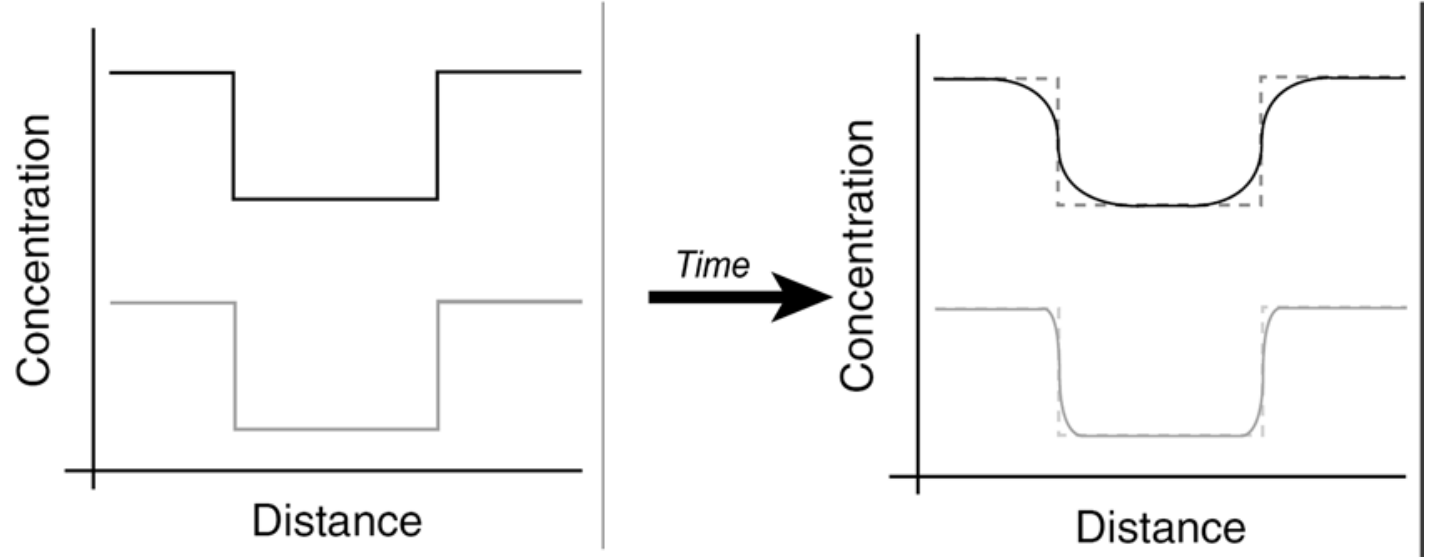

Figure 1.4: Diagram modified from Morgan and Blake (2006) to illustrate how an originally sharp compositional boundary in a crystal (left) degrades over time due to diffusion (right). Black line represents the concentration curve for an element that diffuses more quickly in the crystal and lower (grey) curve for one that diffuses more slowly. Dashed lines in the right-hand graph show overlain initial concentrations from the left-hand graph. With knowledge of the magmatic temperature and the speed at which diffusion of the element of interest occurs in the crystal at that temperature, the extent to which diffusion has occurred (e.g. the shape of the top vs. bottom line on the right-hand graph) can be used to calculate the time for which the zones have been adjacent at magmatic temperatures.

\subsection{Geology of Mt Ngauruhoe}

\subsubsection{The Taupo Volcanic Zone and the Tongariro Massif}

The Taupo Volcanic Zone (TVZ) in New Zealand is a region of volcanism and intracontinental back-arc extension associated with the north-westward oblique subduction of the oceanic Pacific Plate beneath the Australian Plate at the Hikurangi Trough (Cole, 1990; Figure 1.5). It has had an average eruption rate of $0.28 \mathrm{~m}^{3} \mathrm{~s}^{-1}$ over the last 0.3 Myr determined from the exposed eruptives, making it one of the most frequently active and productive rhyolitic systems on Earth (Wilson et al., 1995). The crustal basement comprises Paleozoic-Mesozoic indurated sandstones and mudstones of the Torlesse terrane, originally derived from erosion of the continental margin of Gondwana (Mortimer, 1994). Seismic reflection and refraction data from active and passive 
sources indicate that the original TVZ crustal basement has been thinned to up to half of its pre-deformation thickness (Stratford \& Stern, 2004; Harrison \& White, 2004). This extension has been largely accommodated by a set of densely distributed NE-SW striking normal faults known as the Taupo Fault Belt, combined with dyke intrusion and the opening of vertical extension fractures (Rowland and Sibson, 2001).

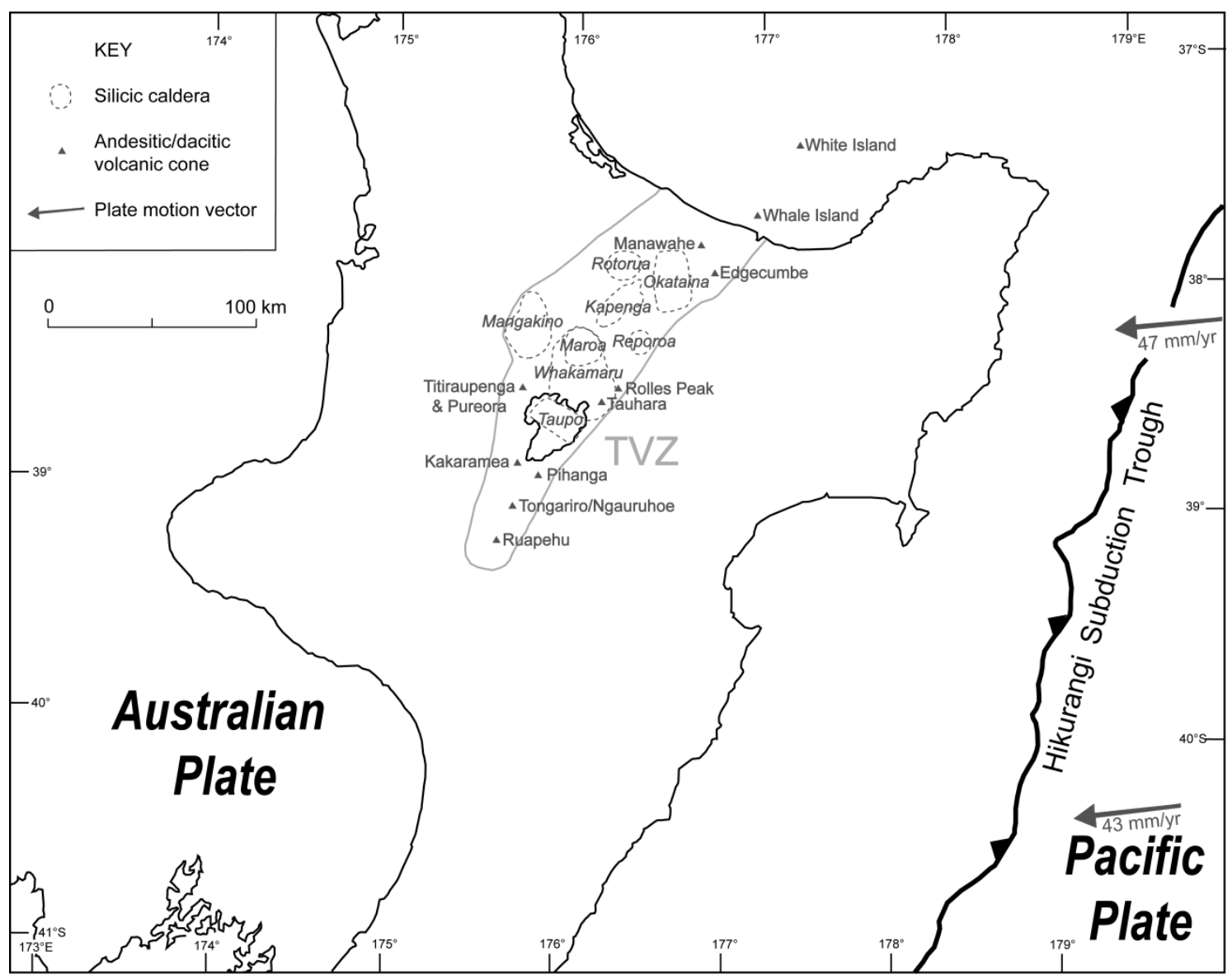

Figure 1.5: North Island of New Zealand showing the location of the subduction trench, relative motion of the Pacific Plate relative to the Australian Plate, and the location of the TVZ with some of the rhyolitic-andesitic volcanism associated with it. Figure is modified after Browne et al. (1992), Spinks et al. (2005) and Nicol and Wallace (2007).

Volcanism in the TVZ began around 2 Ma with andesitic activity preceding the $\sim 1.6 \mathrm{Ma}$ onset of rhyolitic activity (Houghton et al., 1995; Wilson et al., 1995). Erupted material has included rhyolite, andesite, and high alumina basalt along with minor amounts of dacite arising from the mixing of rhyolitic and andesitic magmas (Graham et al., 1995). Rhyolitic volcanism is dominant, representing $>90 \%$ of the eruptives by volume whilst high-alumina basalts represent only $\sim 0.1 \%$ of the total volume of exposed volcanic rocks (Graham et al., 1995). There is some spatial separation evident with regard to the 
nature of volcanism. Basalts are relatively evenly, but sparsely, distributed across the entire TVZ, whereas rhyolites dominate the central portion, and the northeast and southwest segments are dominated by andesitic volcanoes, with an absence of rhyolitic calderas (Wilson et al., 1995; Houghton et al., 1995).

Located in the southwest segment of the TVZ is Ngauruhoe, the youngest cone of the Tongariro Massif (Figure 1.6). The Tongariro Massif is a dominantly andesitic cone complex comprising ca. 17 compositionally diverse nested and overlapping cones, which show no apparent systematic trends in location or geochemistry through time (Hobden et al., 1999). It is part of a larger set of andesitic volcanoes in the southern TVZ referred to as the Tongariro Volcanic Centre, which comprises three other major andesitic massifs in addition to Tongariro/Ngauruhoe. These are Ruapehu, Kakaramea and Pihanga. Along with these larger centres, the Tongariro Volcanic Centre encompasses the four smaller cones and flows of Mangakatote, Hauhangatahi, Pukeonake and Ohakune (Cole, 1978; Figure 1.6). The majority of the Tongariro Volcanic Centre andesites are medium-K, and all are quartz-hypersthene normative (Cole et al., 1986; Graham et al., 1995). Most can be grouped as being plagioclase-twopyroxene, plagioclase phyric, or olivine-pyroxene phyric. However, clinopyroxenephyric andesites are also widespread, and there are rare occurrences of hornblendebearing andesites (Graham et al., 1995). K-Ar dating by Hobden et al. (1996) indicates that growth of the visible portion of the Tongariro Massif has taken place since 275 ka, with intervals of rapid cone growth occurring at 210-200 ka, 170-130 ka, and 25 ka to the present. 


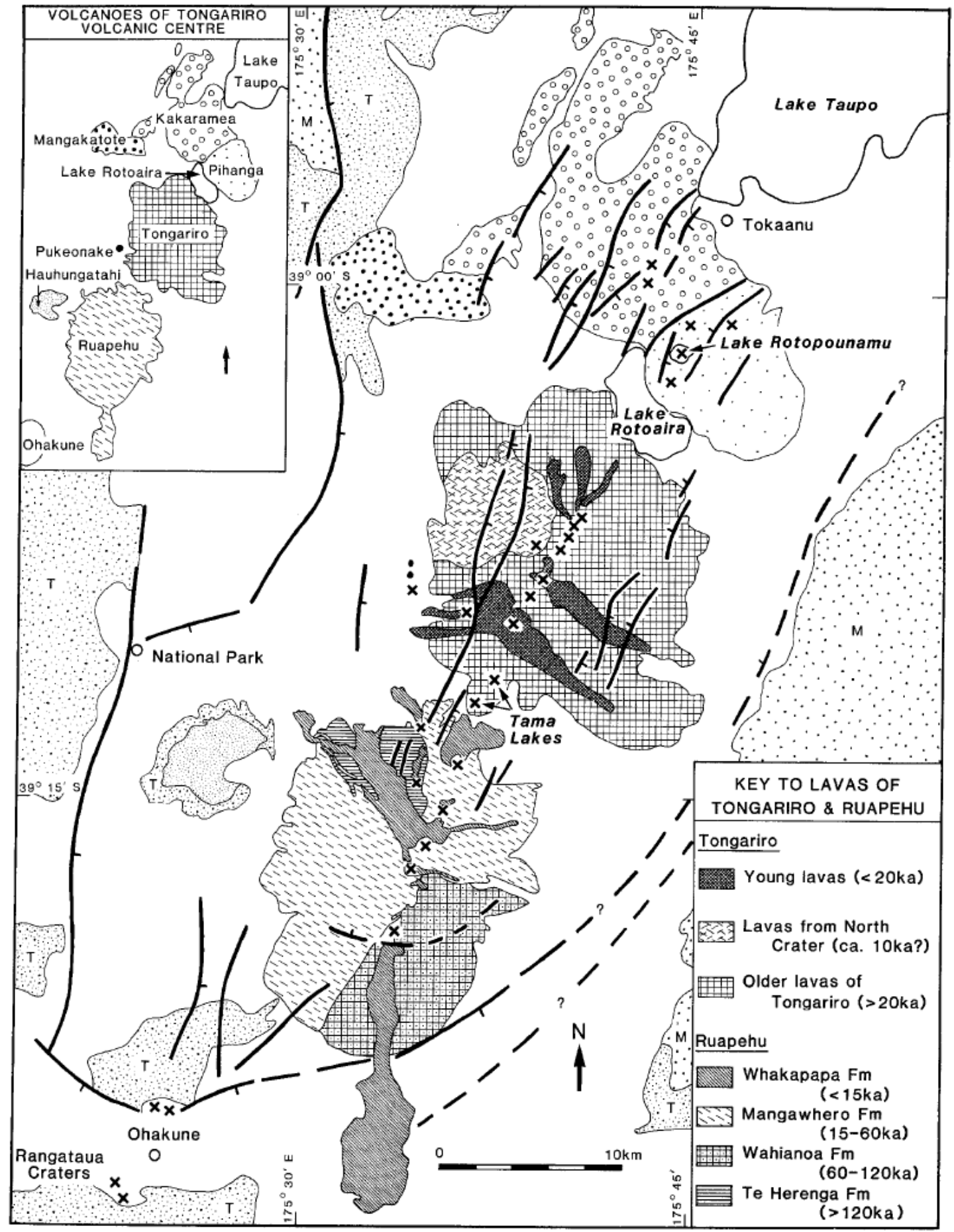

Figure 1.6: Simplified geological map from Cole (1990) showing the volcanoes within the Tongariro Volcanic Centre, along with some of the associated faulting. Key in bottom right gives approximate ages for the Tongariro and Ruapehu eruptives. Main ( $<50 \mathrm{ka}$ ) vents are marked by crosses. $M$ denotes Mesozoic greywacke-argillite and $T$ denotes Tertiary sediments. 


\subsubsection{Early eruptive history of Ngauruhoe}

Information on the cone building phase and early eruptive history of Ngauruhoe is provided largely by the Mangatawai Tephra (Figure 1.7), a set of andesitic ash beds conformably underlying the Taupo Tephra and overlying the Papakai Formation (Donoghue et al., 1995). Isopachs by Gregg (1960) and Donoghue et al. (1995) show that the Mangatawai Tephra was erupted from the Tongariro Volcanic Centre, with the majority erupted from Ngauruhoe. The type section is on the Desert Road just south of the Mangatawai Stream ([T19/489238] based on the NZMS 260 1:50,000 map series). At the type section the Mangatawai Tephra is $0.79 \mathrm{~m}$ thick; the upper $0.29 \mathrm{~m}$ being a dark brown fine ash and the lower $0.50 \mathrm{~m}$ consisting of interbedded dark grey and very dark grey medium ash containing Nothofagus sp. leaves (Topping, 1973). Plant material from the lower $7.5 \mathrm{~cm}$ of the leaf-bearing ash was originally radiocarbon dated at $2500 \pm 200$ yrs BP (Fergusson and Rafter, 1959; NZ186). However, recent re-dating of a layer near the base of the Mangatawai Tephra using pollen gives an age of $3470 \pm$ 20 yrs BP (Möbis et al., 2008). Tephras of Ngauruhoe and Tongariro that overlie the 1850 yr B.P. Taupo Tephra are termed the Ngauruhoe Formation, and are interbedded with the Tufa Trig Formation tephras originating from Ruapehu (Donoghue et al., 1995). Tephrochronological studies using geochemical analyses of volcanic glass to distinguish between Ruapehu and Ngauruhoe tephras reveal a continual decrease in the volcanic explosivity indices of eruptions over Ngauruhoe’s history (Möbis et al., 2008). 

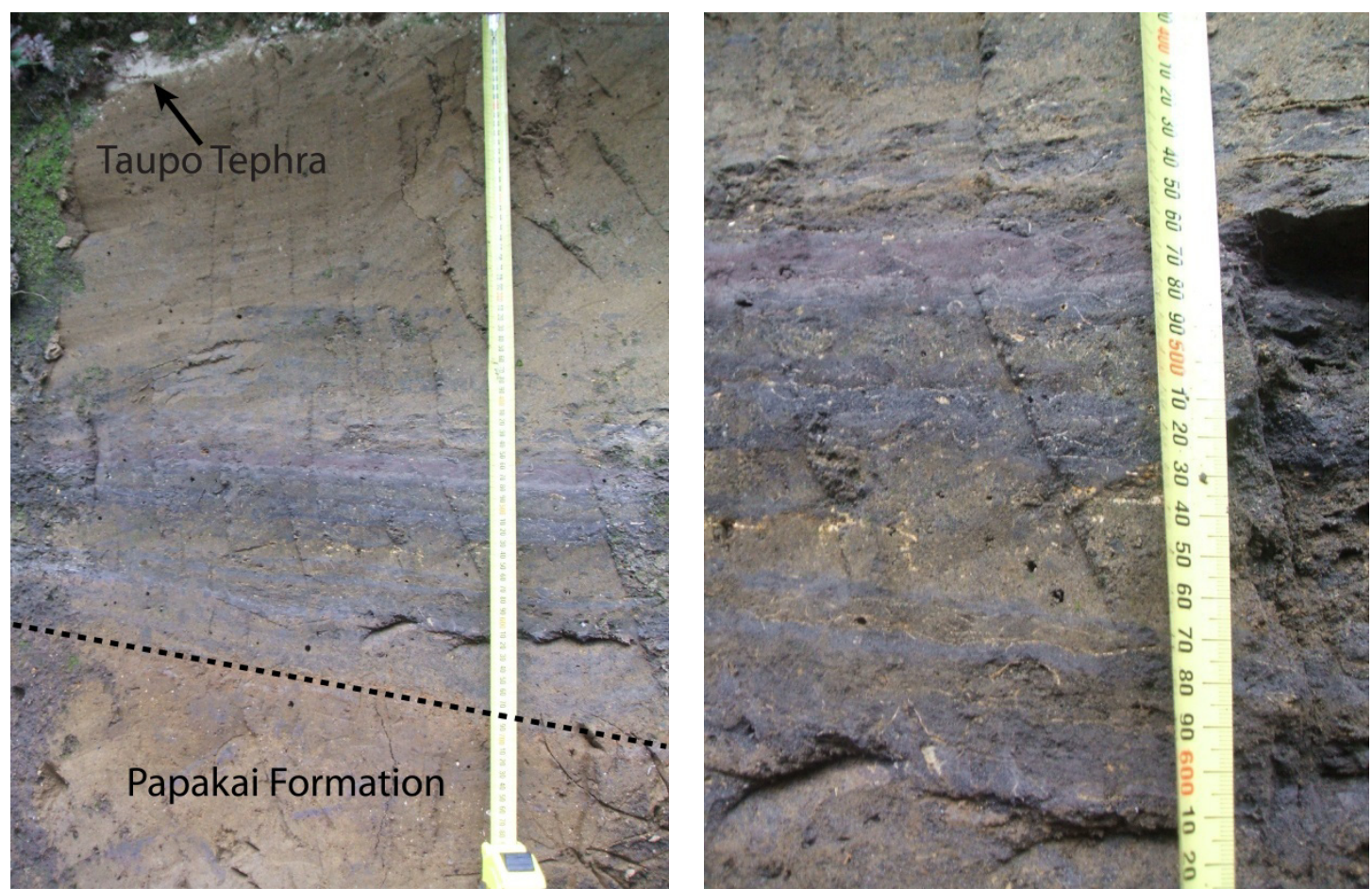

Figure 1.7: Photographs of the Mangatawai Tephra near the type section [T19/489238]. In the image on the left the white of the overlying Taupo Tephra is visible in the top-left corner of the photograph, and the more orange-brown colours of the Papakai Formation beneath the darker layers of the Mangatawai Tephra. The tape measure is $780 \mathrm{~mm}$ from top to bottom. The image on the right is a close-up of the lower section of the Mangatawai Tephra.

Hobden et al. (2002) divided the exposed Ngauruhoe lava flows into 5 groups based on age and chemical composition (Figure 1.8), with stratigraphic relationships suggesting that cone growth has occurred in a sectorial manner controlled largely by summit morphology. The lavas comprise porphyritic to glomeroporphyritic olivine-bearing basaltic andesites, andesites, and olivine-andesites, with $\mathrm{SiO}_{2}=54-59$ wt\% (Hobden, 1997; Hobden et al., 2002; Figure 1.9). Whole-rock geochemistry suggests that magma batches at Ngauruhoe are generally small and short-lived, and show no single geochemical trend or simple evolutionary trend throughout time (Hobden et al., 1999). In addition, there is some evidence for magma mixing shown by the textural features and chemical zoning of the crystal population. Sieve-textured plagioclase phenocrysts, which suggest mixing and/or rapid decompression, are abundant throughout the Ngauruhoe lavas. A number of lavas also contain orthopyroxene reaction rims around olivine, augite rims around orthopyroxene, phenocrysts with strong reverse zoning, and olivine phenocrysts more forsteritic than would be expected given their host rock $\mathrm{Mg}$ number (Hobden, 1997; Hobden et al., 2002). 

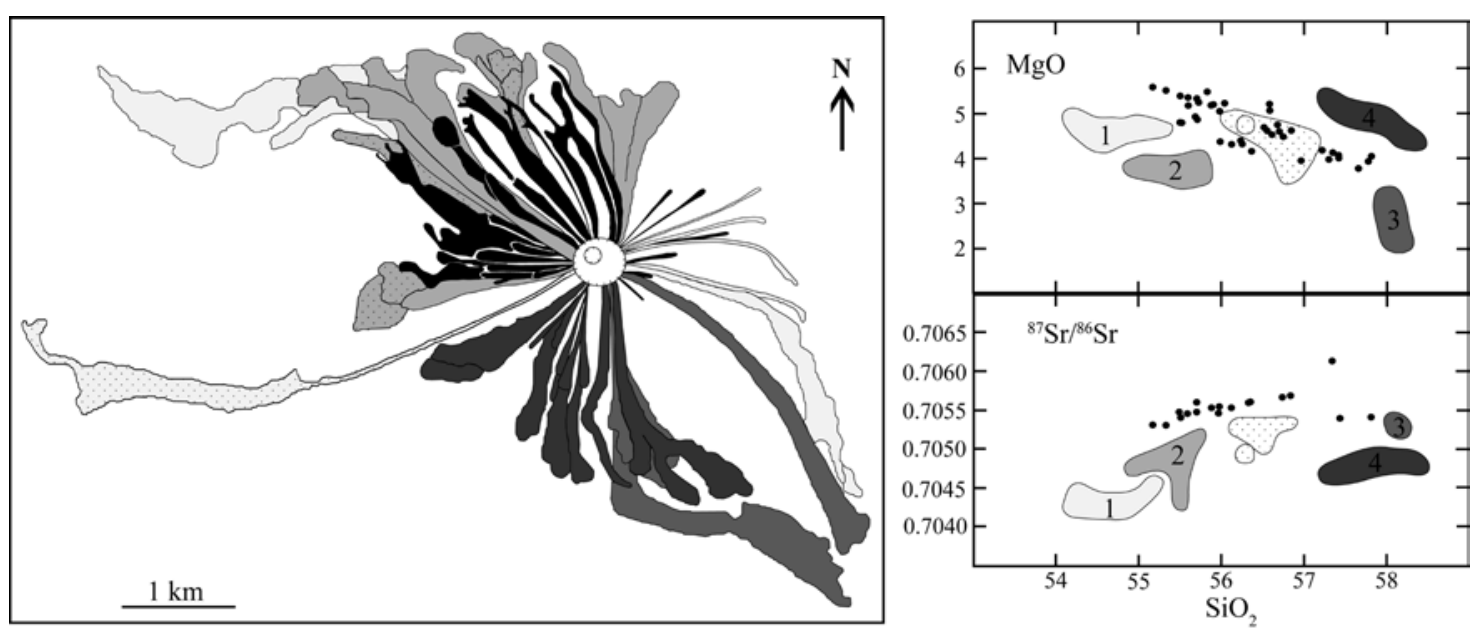

Figure 1.8: Diagram modified from Hobden et al. (2002) showing the grouping of the exposed Ngauruhoe lava flows based on age and chemical composition, with group 1 being the oldest flows and group 5, shown in black, being the most recent (historical) flows. Stippled lava flows are those which have unique chemistry from the other flows in their group (plotted in stippled grouping on the bivariate plots).

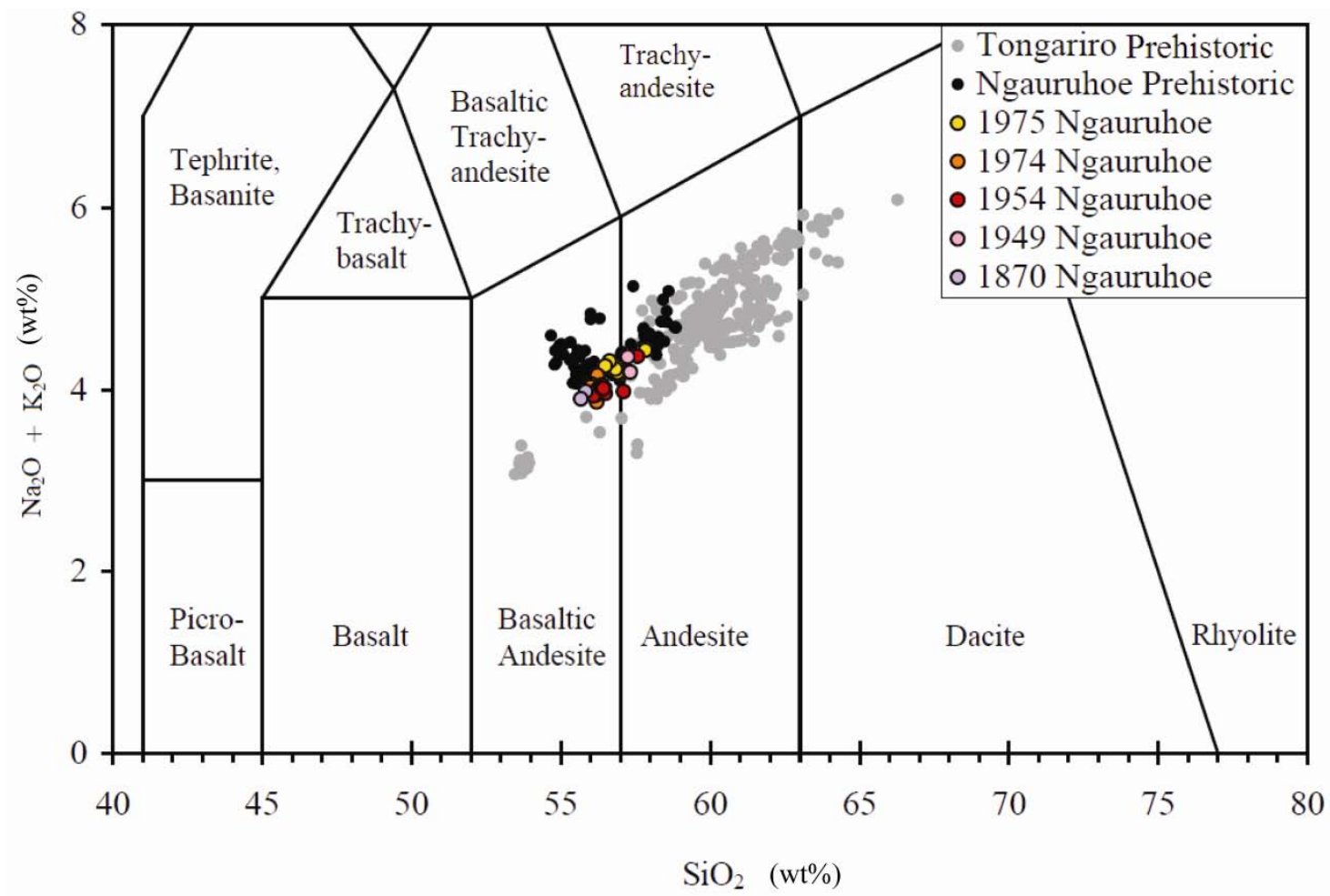

Figure 1.9: Total alkalis silica classification diagram for samples from Ngauruhoe and Tongariro lava flows from Hora (2003), using whole rock geochemical data taken from Hobden (1997). 


\subsubsection{Historical eruptions and current understanding of Ngauruhoe}

Until 1975, Ngauruhoe was one of the most continuously active volcanoes in New Zealand, having produced ash eruptions every few years since records began for the volcano in 1839. A complete list of these eruptions excluding steam-only events can be found in Gregg (1960). Most notably, lava and block-and-ash flows involving the eruption of fresh magmatic material accompanied the eruptions of 1870, 1949, 1954-55 and 1974-75. These eruptions are summarised in Table 1.1.

Table 1.1: Summary of the main historical eruptions from Mt Ngauruhoe.

\begin{tabular}{|c|c|c|c|c|}
\hline & 1870 & 1949 & 1954 & 1974-1975 \\
\hline Eruptive Period & $\begin{array}{l}\text { April-August } \\
1870\end{array}$ & $\begin{array}{c}9^{\text {th }}-12^{\text {th }} \text { February } \\
1949\end{array}$ & $\begin{array}{c}13 \text { May- } 26 \\
\text { September } 1954 \\
\text { (-March 1955) }\end{array}$ & $\begin{array}{c}19^{\text {th }} \text { February } \\
1975 \\
(\sim \text { Dec } 1973-F e b \\
1975)\end{array}$ \\
\hline Eruption Style & & $\begin{array}{l}\text { Strombolian, } \\
\text { Effusive, } \\
\text { Vulcanian }\end{array}$ & $\begin{array}{l}\text { Strombolian, } \\
\text { Effusive }\end{array}$ & Vulcanian \\
\hline $\begin{array}{l}\text { Approximate } \\
\text { volume of } \\
\text { material erupted }\end{array}$ & $\sim 870,000 \mathrm{~m}^{3}$ & $915,000 \mathrm{~m}^{3}$ & $6,500,000 \mathrm{~m}^{3}$ & $2,000,000 \mathrm{~m}^{3}$ \\
\hline $\begin{array}{l}\text { Eruption } \\
\text { Products }\end{array}$ & Two lava flows & $\begin{array}{l}\text { Block-and-ash } \\
\text { flow, lava flow }\end{array}$ & $\begin{array}{c}>10 \text { aa lava } \\
\text { flows, scoria } \\
\text { cone }\end{array}$ & $\begin{array}{l}\text { Block-and-ash } \\
\text { flows, ash fall }\end{array}$ \\
\hline
\end{tabular}

Sources: Hector (1870), Cloud (1951), Gregg (1960), Nairn and Self (1978), Hobden et al. (2002). Approximate volumes are for the eruption products listed (i.e. the 1954 and 1975 eruption volumes are inclusive of the scoria cone and ash fall, respectively).

There has been some uncertainty as to the dates and locations of the lava flows that took place around 1870, as is discussed by Gregg (1960). However, an account by Hector (1870) indicates that the eruption began shortly after an earthquake in the area on the evening of the 5th April 1870, with lava flow(s) occurring around the 7th-10th July: "a broad stream of red hot lava is distinctly visible flowing down the side of the mountain in a wavy, irregular mass”. Whilst the exact location of the lava flows is not described, Gregg (1960) suggests that the flows mapped by Battey (1949) as IX and X in the Mangatepopo valley and labelled by Cloud (1951) as possibly being from 1869 or 1881 were likely to have been those erupted in 1870 (Figure 1.10), and they have been treated as such since (Hobden, 1997; Hobden et al., 1999, 2002; Hora, 2003). 

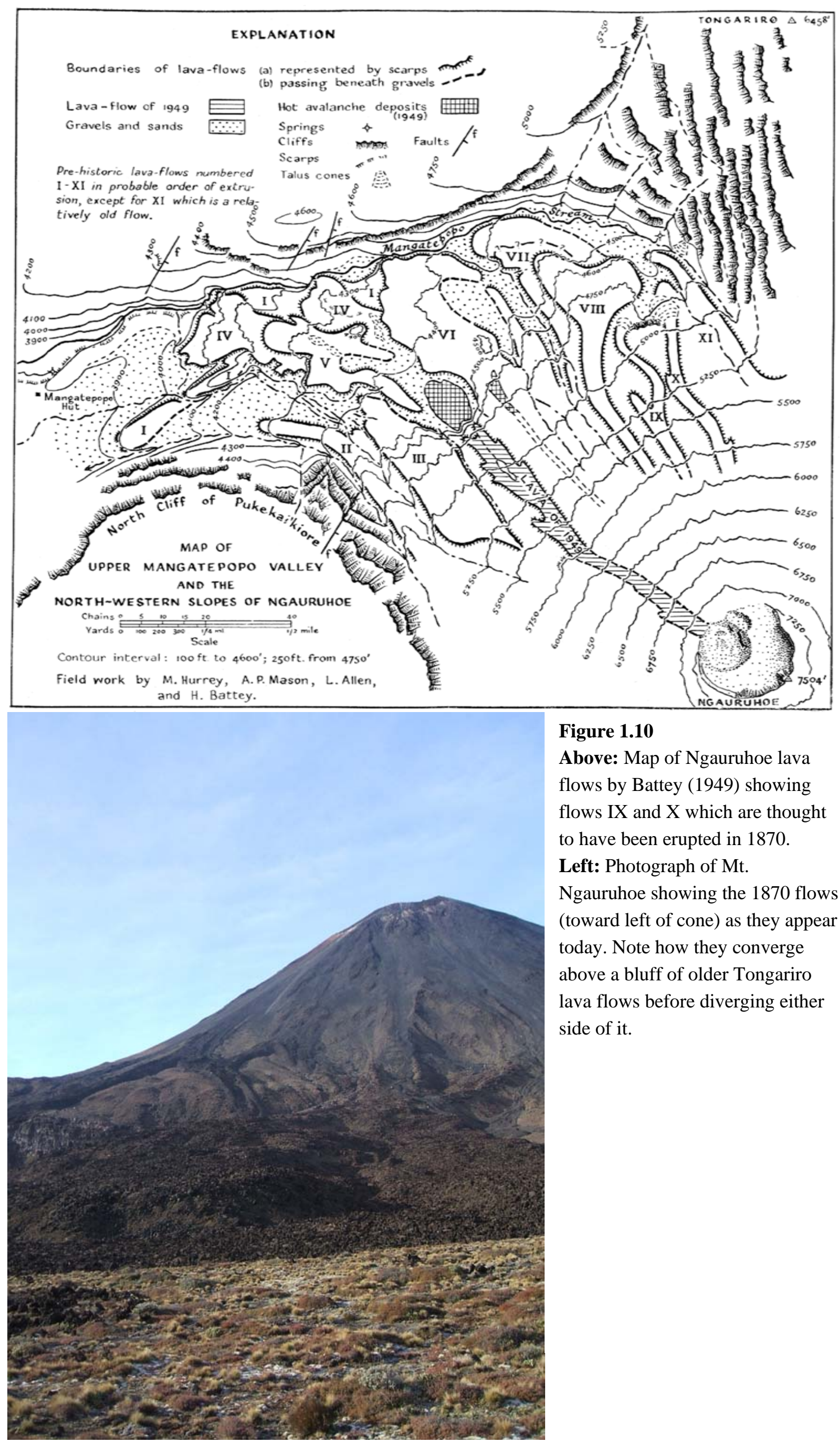

Figure 1.10

Above: Map of Ngauruhoe lava flows by Battey (1949) showing flows IX and $\mathrm{X}$ which are thought to have been erupted in 1870 .

Left: Photograph of Mt.

Ngauruhoe showing the 1870 flows (toward left of cone) as they appear today. Note how they converge above a bluff of older Tongariro lava flows before diverging either side of it. 
The 1949 eruption was a relatively short-lived strombolian eruption that commenced on the morning of the 9th February with the ejection of plug material from one of the crater's two vents resulting in block-and-ash flows (Cloud, 1951). The crater then filled with lava which overflowed the lowest part of the rim on the north-west side of the cone that night, and had essentially stopped moving by February 12th (Battey, 1949; Cloud, 1951; Figure 1.11).
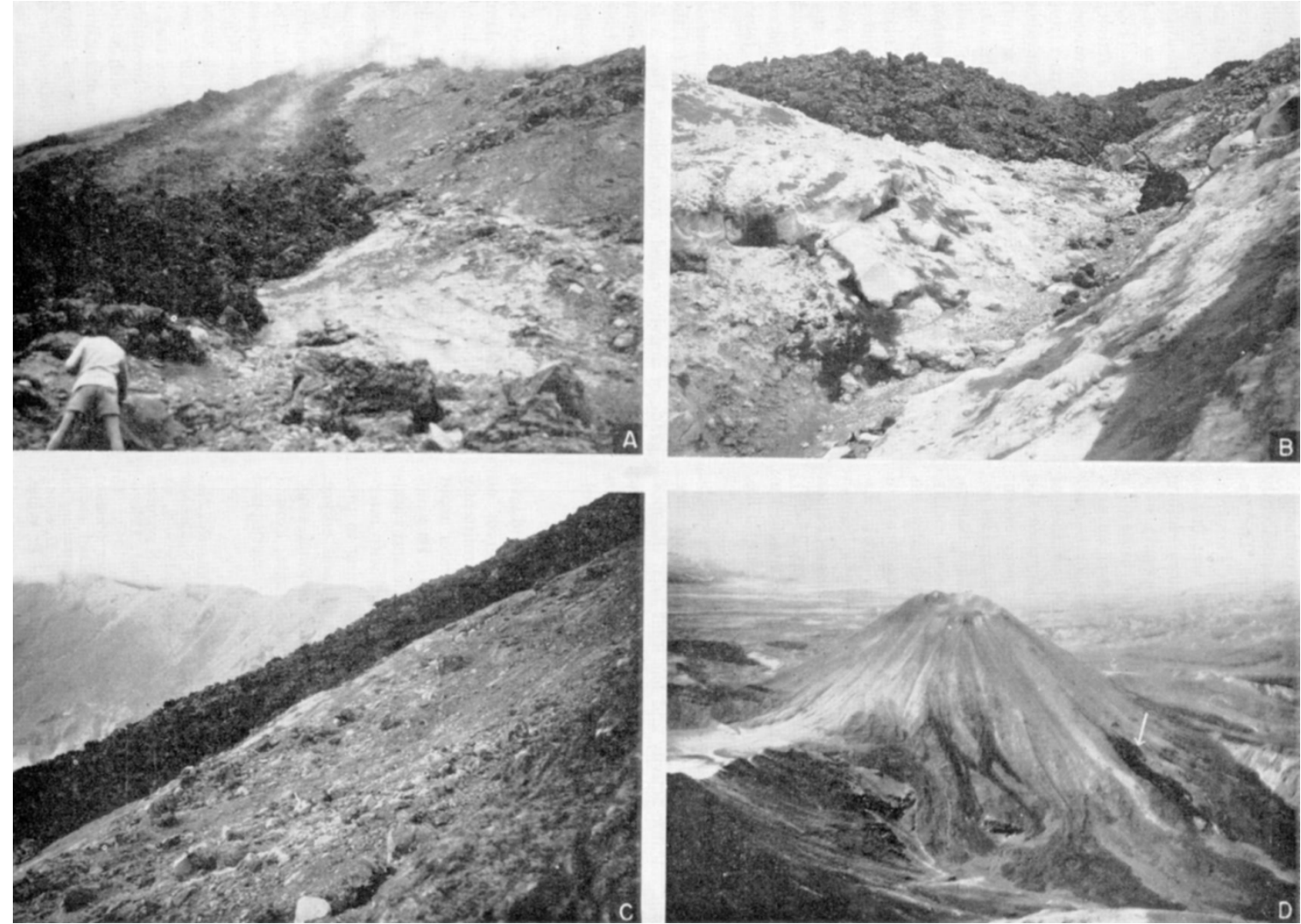

Figure 1.11: Photographs of the 1949 lava flow shortly after its emplacement (Cloud, 1951). (A) View looking up the flow from near its termination, showing median and lateral ridges. Part of the track of the preceding hot avalanche is visible toward the right of the image. (B) One of the terminal lobes of the 1949 lava flow, avalanche track in foreground. (C) Side view of the lava flow. (D) Aerial photograph showing the location of the 1949 lava flow (white arrow near right), with the 1870 lava flows also clearly visible in the centre of the image.

The eruptions of 1954 commenced with ash explosions on 13th May 1954, although lava had been observed in the crater 5 months previously (Gregg, 1956). During the eruption period, at least 10 , and possibly up to 17 , 'a a $\bar{a}$ lava flows occurred along with the build up of a scoria cone in the crater which together amounted to a volume of $\sim 6,500,000 \mathrm{~m}^{3}$ of extruded material, with several block-and-ash flows occurring in addition to this (Gregg, 1960; Hobden et al., 2002). A map by Hobden et al. (2002) indicating the locations and dates of some of these 1954 lava flows is shown in Figure 
1.12. Lava remained in the crater until June 1955, despite the last ash explosion having taken place on 10th March 1955 (Gregg, 1956).

In January 1974 and February 1975, sub-plinian and vulcanian eruptions resulted in a series of pyroclastic avalanches which were funnelled by low points on the summit down the north-western sector of the cone. Avalanches resulted from both the collapse of piles of agglutinate that were accumulating during the eruption and collapse of the dense central part of the eruption cloud during the vulcanian phase (Nairn and Self, 1978; Lube et al., 2007). Despite its former high eruption frequency, Ngauruhoe has not erupted since 1975.

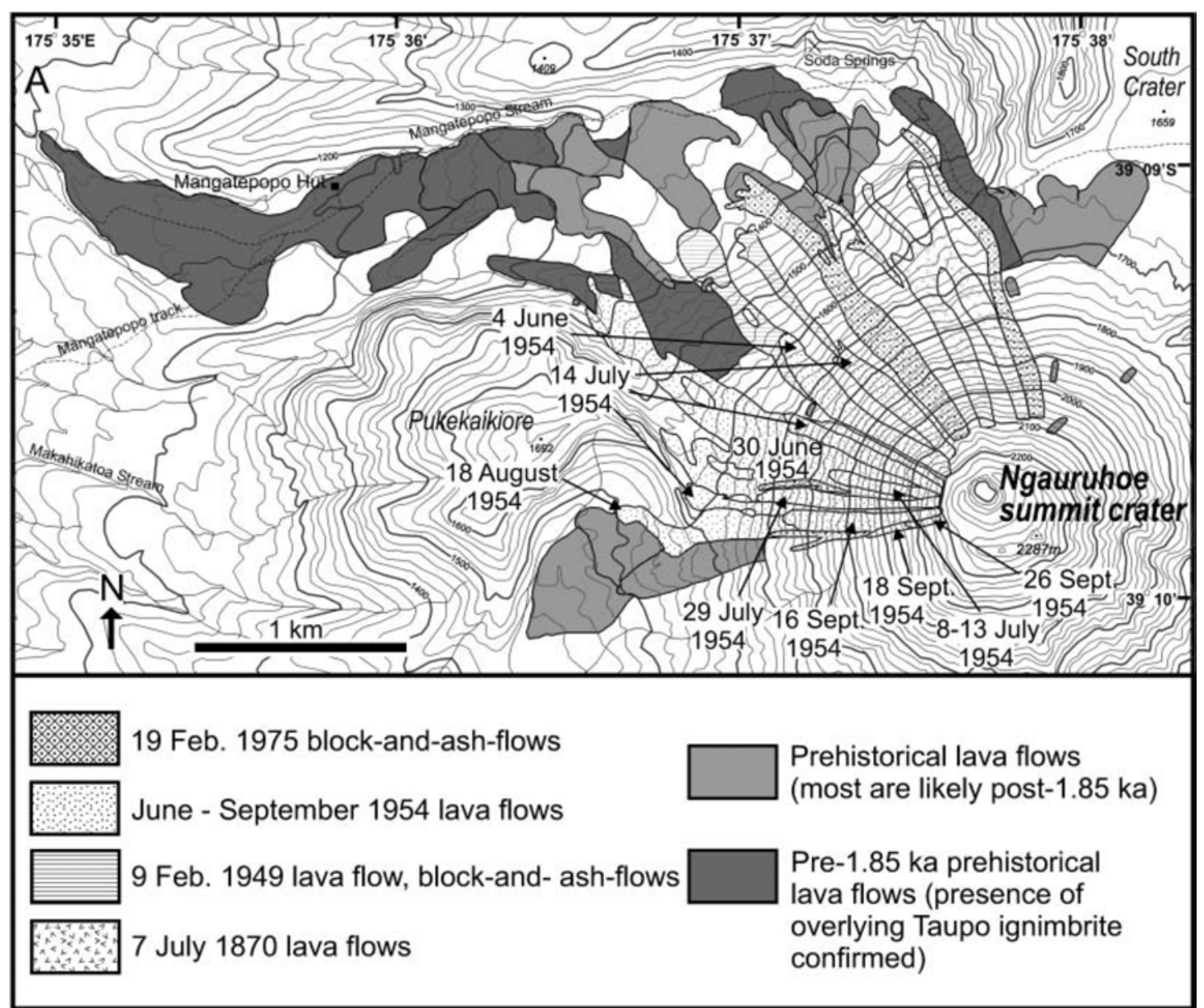

Figure 1.12: Map from Hobden et al. (2002) showing the locations and dates of the historical Ngauruhoe lava and block-and-ash flows. 


\subsection{Structure of this thesis}

This thesis is structured in the following way:

Chapter 1: An introductory chapter describing the nature and petrogenesis of subduction volcanism with specific reference to the Taupo Volcanic Zone. This chapter also provides a geological background to Ngauruhoe and describes the objectives and structure of this thesis.

Chapter 2: A chapter describing the Ngauruhoe lava flows that were sampled along with detailed petrographic descriptions.

Chapter 3: A chapter that presents the results obtained from analyses of mineral major and trace element chemistry for all phases within the Ngauruhoe lava flows and from diffusion modelling of zoning within the clinopyroxene crystal population.

Chapter 4: A chapter that interprets and expands upon the results of the previous two chapters, placing them in the context of other literature and presenting the major results and implications of this study.

Chapter 5: A final chapter that synthesises the main conclusions of this thesis. This chapter also makes suggestions as to potential future work.

A series of appendices as follows:

A1 Sample list

A2 Analytical methods

A3 EPMA and LA-ICP-MS data tables

A4 Geothermometry

A5 Diffusion modelling background, methods and data 


\section{CHAPTER TWO: FIELDWORK AND PETROLOGY}

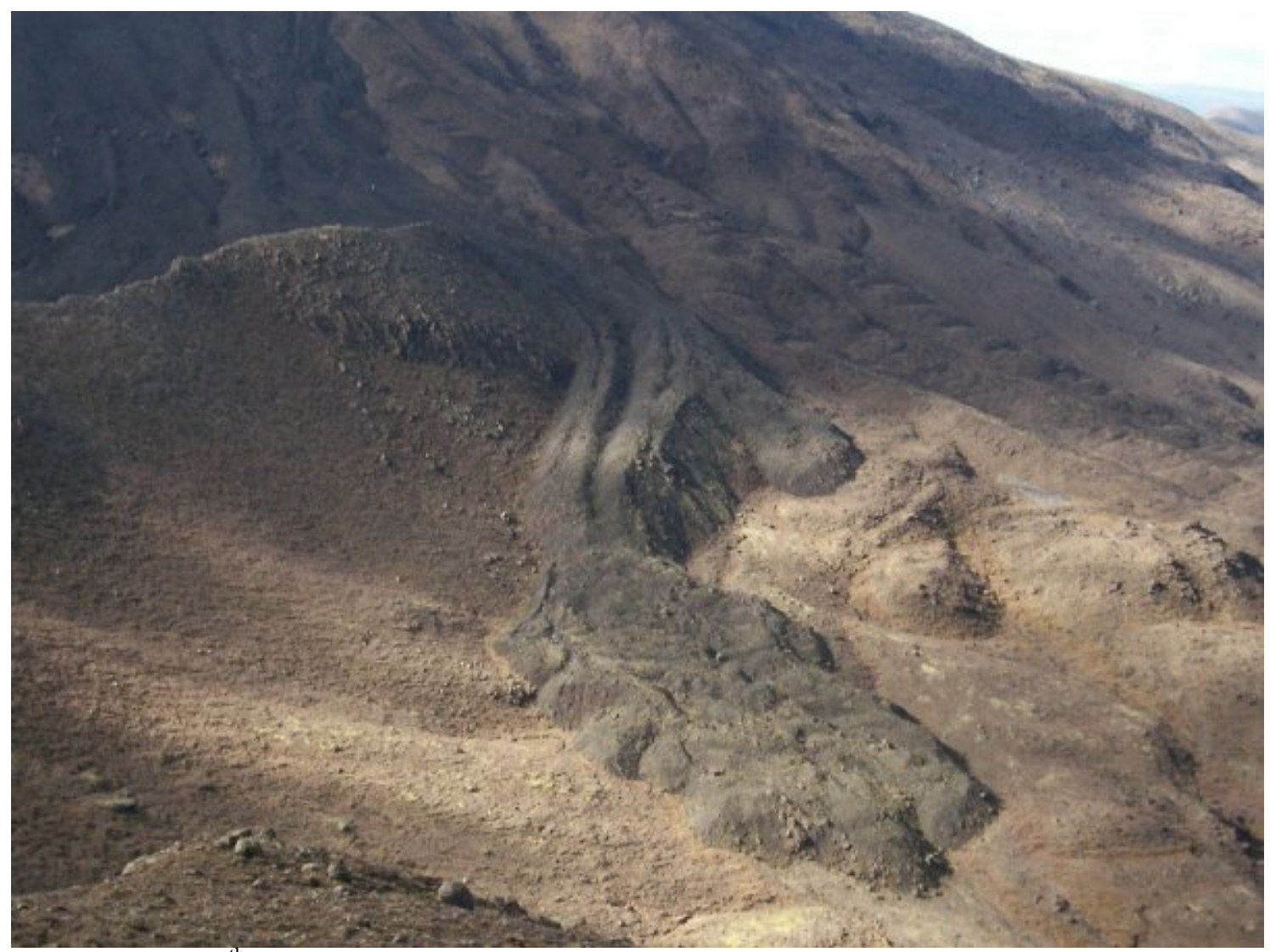

Plate 2: The $18^{\text {th }}$ August 1954 lava flow viewed from Pukekaikiore. Photograph by Chelsea Tutt. 


\subsection{Fieldwork}

Fieldwork was carried out in January 2008, using aerial photographs from New Zealand Aerial Mapping Ltd (photographs SN 8440 F/20 and G/21) along with a geological map of the lava flows from Hobden et al. (2002) to plan sampling and to confirm locations in the field. Samples were taken from lava flows in the Mangatepopo Valley both beneath and above the $1.8 \mathrm{ka}$ Taupo Ignimbrite, and on the north-western flanks of $\mathrm{Mt}$ Ngauruhoe with the aim of collecting a sample suite encompassing a wide time-span of Ngauruhoe's eruptive history. There was a particular focus on the historical lava flows in order to allow the crystal residence times, petrology and geochemistry of the flows to be linked to known eruption dates. A map showing the lava flows and sample locations is given in Figure 2.1, and a full sample list with GPS co-ordinates is provided in Appendix 1.

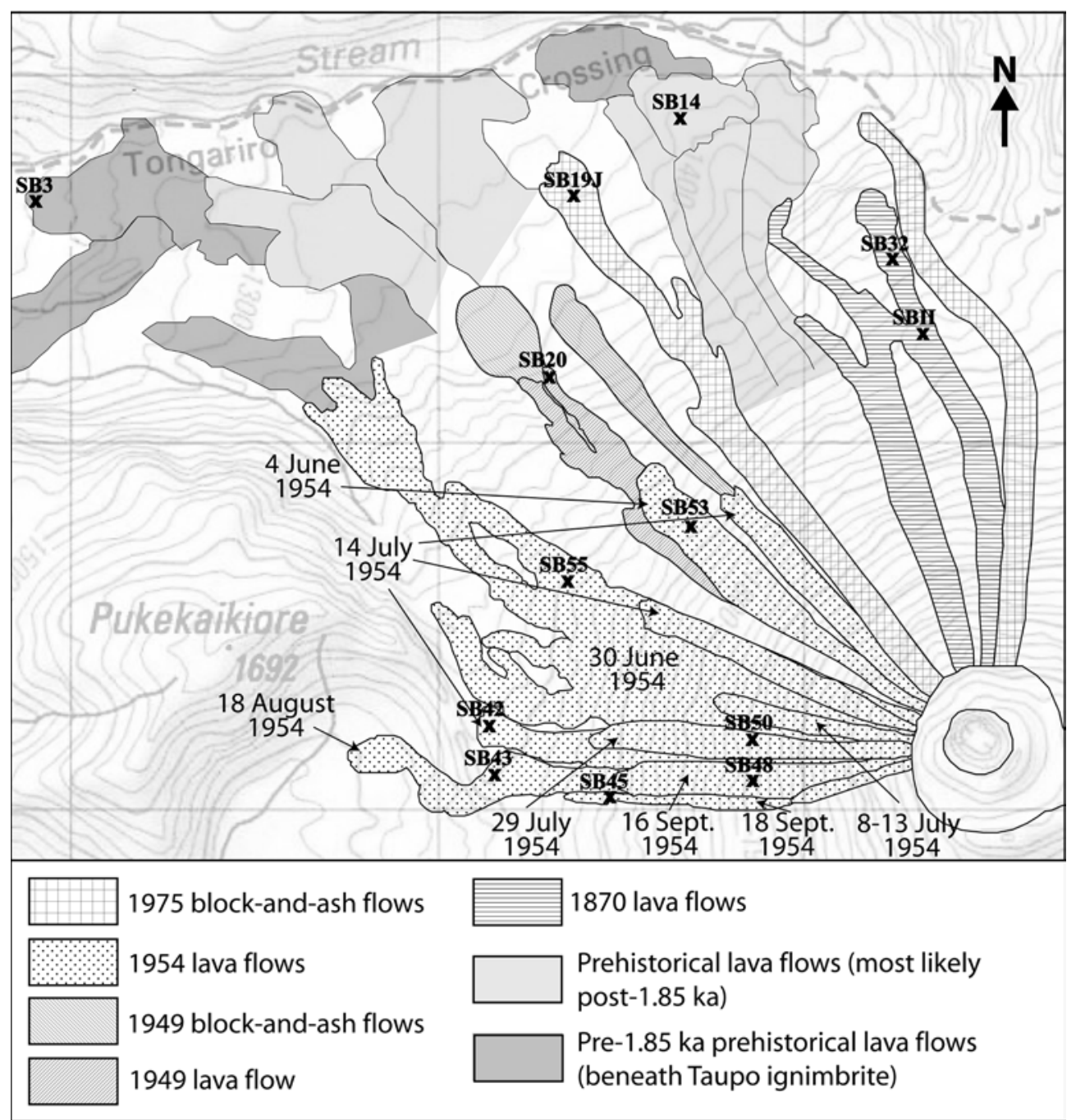

Figure 2.1: Map of the Ngauruhoe lava flows modified from Hobden et al. (2002) to show the locations of samples used in this study. Topographic underlay is sourced from Topo50 Map BH34 Raurimu, Crown Copyright Reserved. 


\subsection{General petrology of the historical lava flows}

Whole rock data for the historical Ngauruhoe lava flows places them in the basaltic andesite to andesite field (Hobden, 1997). All samples are predominantly plagioclase and pyroxene phyric, with minor olivine. Plagioclase is the most abundant phenocryst phase, and orthopyroxene is generally more abundant than clinopyroxene. Small grains of highly altered amphibole can sometimes be found, but are rare. Feldspathic and quartzose xenoliths and micro-xenoliths (Figure 2.2) are a common feature throughout the flows. In-depth work on the xenoliths from the 1954 lava flows by Steiner (1958) suggests an acid gneiss as the origin, but later work by Hobden (1997) argues for a cognate (hypabyssal crystallisation) origin for feldspathic xenoliths and a quartz vein origin for quartzose xenoliths.

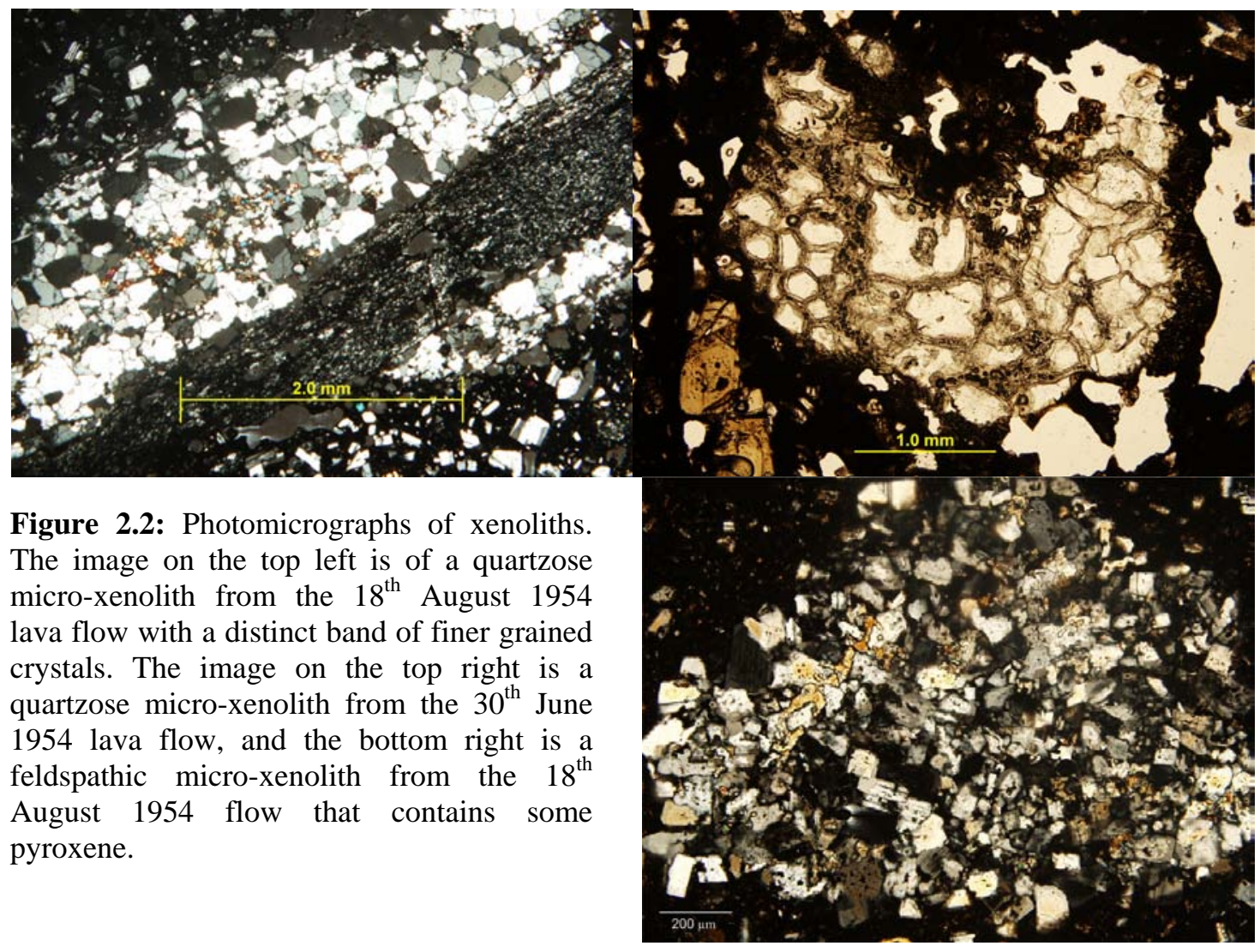

The groundmass texture of the lava flows is hyalopilitic, consisting of acicular microlites of plagioclase and orthopyroxene \pm titanomagnetite set in interstitial glass. Contrary to the suggestion of Steiner (1958) that plagioclase microlites do not always occur in the groundmass, plagioclase microlites were present in all samples analysed in this study and were equally abundant as pyroxene. This can be observed in Figure 2.3, 
where the darker acicular crystals are plagioclase microlites. The groundmass is very microlite rich, and as a result areas of groundmass glass large enough to analyse by electron microprobe were difficult to find. Comparative images of the groundmass to show differing textures between the historical lava flows are shown in Figure 2.3. Whilst the groundmass texture may largely relate to how quickly the lava flow cooled and perhaps the part of the lava flow that was sampled, as these are the polished thick sections that were worked on, the images have been included so that any way they could influence or relate to the results of the study can be assessed.

The historical lava flows generally have a smaller average crystal size than the prehistorical flows, although the overall size range is about the same. This is illustrated in Figure 2.4. The 1870 lava flow also has the largest average crystal size out of the historical flows, with more of the crystal population in the $700 \mu \mathrm{m}$ to $2 \mathrm{~mm}$ size range than is the case for the later flows, for which by far the majority of crystals are $<1 \mathrm{~mm}$ across. 


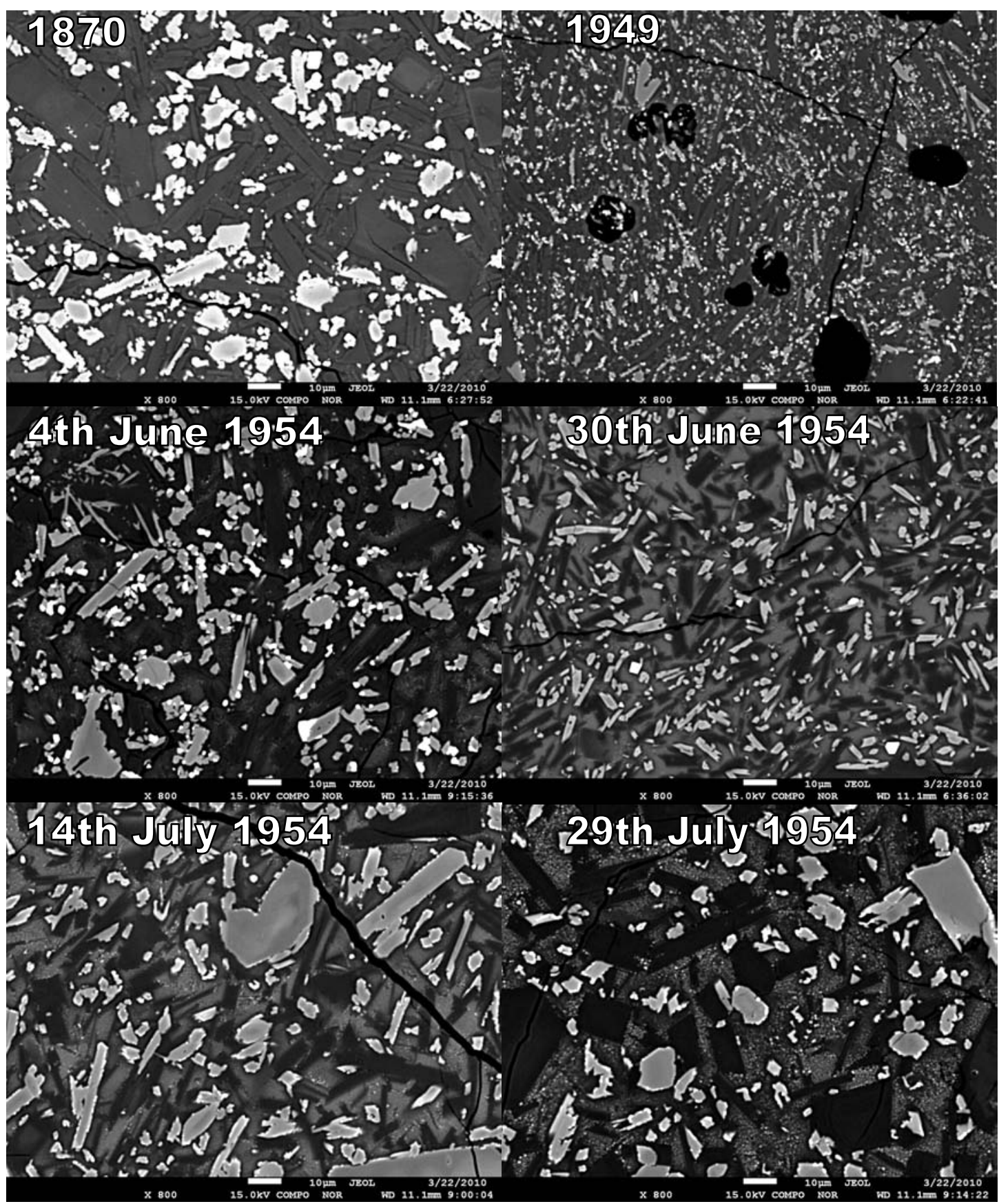




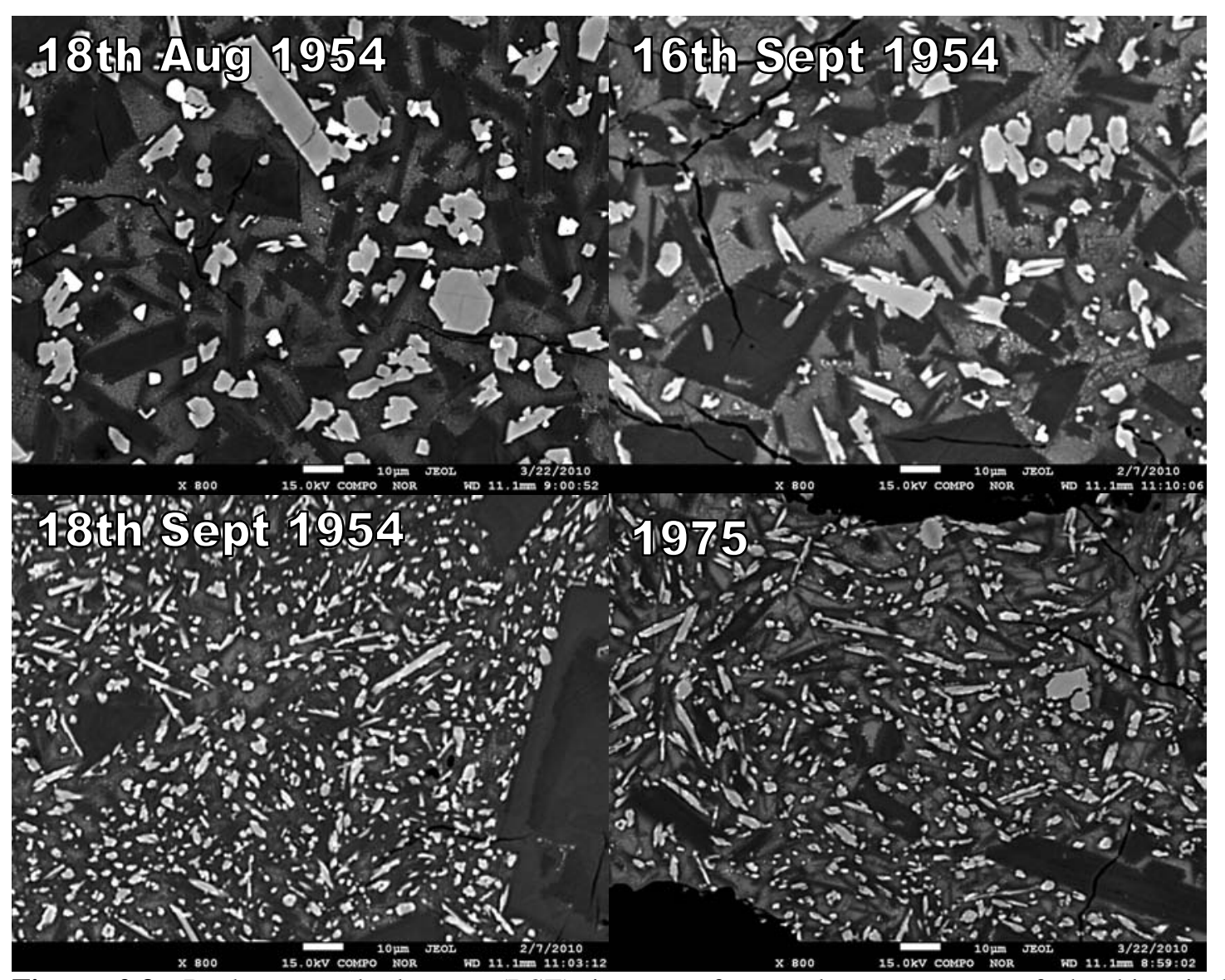

Figure 2.3: Back-scattered electron (BSE) images of groundmass textures of the historical Ngauruhoe lava flows in the polished thick sections used for analyses. All images are taken on the JEOL JXA-8230 Superprobe at $800 \times$ magnification. 


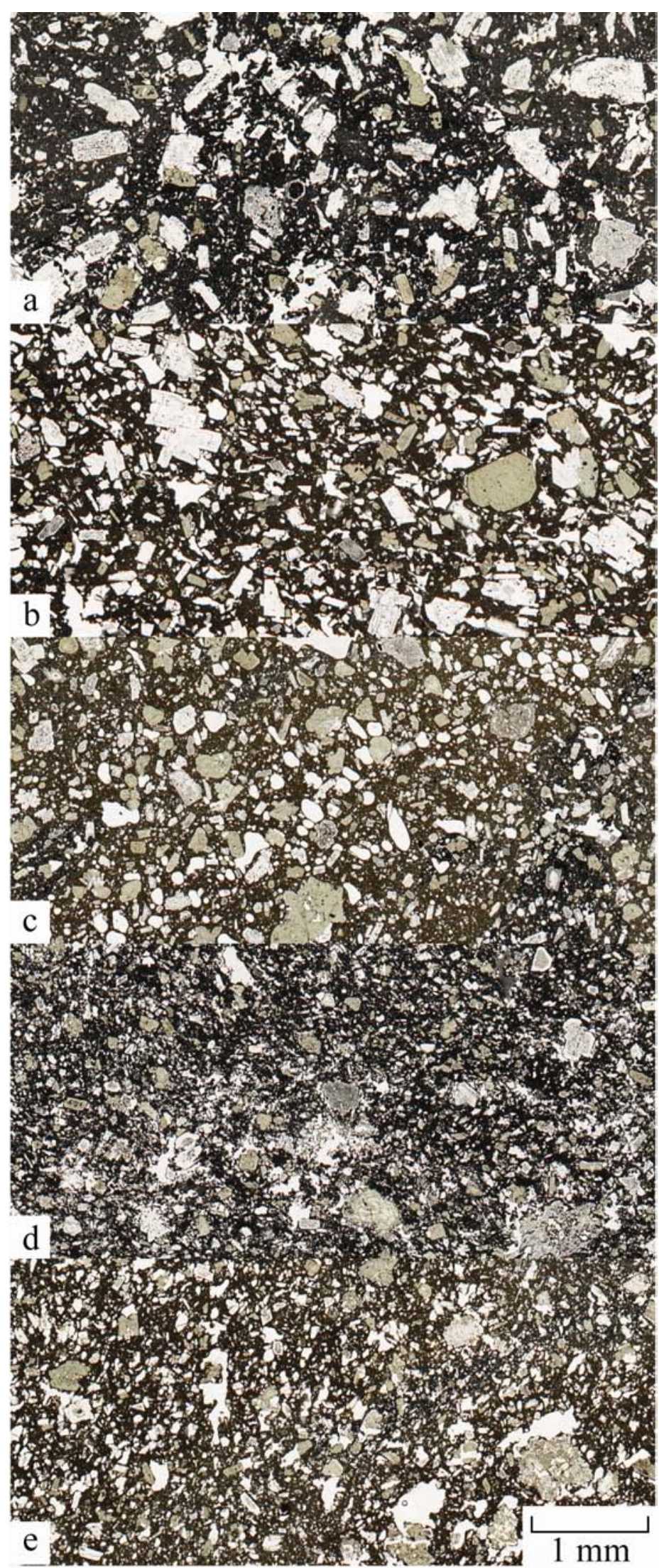

Figure 2.4: Plane light images of thin sections to show the difference in average crystal size between the prehistorical and historical lava flows. a: SB3, a prehistorical lava flow erupted prior to the 1.8 ka Taupo Ignimbrite. b: SB14, a prehistorical lava emplaced some time after the Taupo Ignimbrite. c: SBIII, 1870 lava flow. d: SB20, 1949 lava flow. e: SB55, 30th June 1954 lava flow. 


\subsection{Petrological features of the mineral populations}

\subsubsection{Clinopyroxene}

Clinopyroxene occurs both as individual crystals and as glomerocrysts ( \pm opx). Crystals generally range from $<100 \mu \mathrm{m}$ across up to about $2 \mathrm{~mm}$, with rare crystals as large as $2.7 \mathrm{~mm}$ across. A wide range of zoning patterns can be observed in the clinopyroxene crystals of the historical lava flows, with great variation both within and between the lava flows. A flow-by-flow description of the crystal zoning and textures observed is given below.

1870: Clinopyroxenes from the 1870 lava flow (Figure 2.5) generally have distinct Mgrich cores (Mg\# 83-85) surrounded by more Fe-rich zones (Mg\# 66-79) with another relatively Mg-rich outermost rim (Mg\# 74-82). Core chemistry has frequently been affected by dissolution or chemical re-equilibration with melt inclusions. Inner zoning of the crystals appears to be more diffuse than is observed in the later historical flows, perhaps indicative of longer timescales in the plumbing system prior to eruption.

1949: Like the 1870 lava flow, clinopyroxenes from the 1949 lava flow (Figure 2.6) generally possess a distinct Mg-rich core (Mg\# 85-90), which makes up a larger proportion of the crystal than for the 1870 flow, and has a sharper compositional contrast against surrounding Fe-rich material (Mg\# 68-76). Sometimes a more Mg-rich outermost zone is observable, but the Mg\# of this zone varies greatly between crystals, from Mg\# 73-87 for those that were analysed.

4th June 1954: The clinopyroxene crystal population of the 4th June 1954 lava flow is dominated by crystals that have a rim of Mg\# 73.5-77 adjacent to an inner zone of Mg\# 78-83 (Figure 2.7a-b). Further in is usually a zone, which in some cases is the core, of Mg\# 85-90. In other crystals, core composition is more Fe-rich (Figure 2.7c) or zoning is more complex (Figure 2.7d-e). A separate crystal type has a series of diffuse zones bound by a sharp more Mg-rich rim (Figure 2.7f). Melt inclusions are frequently concentrated into particular zones, sometimes more Fe-rich zones and sometimes in the mafic core (Figure 2.7g-h). 


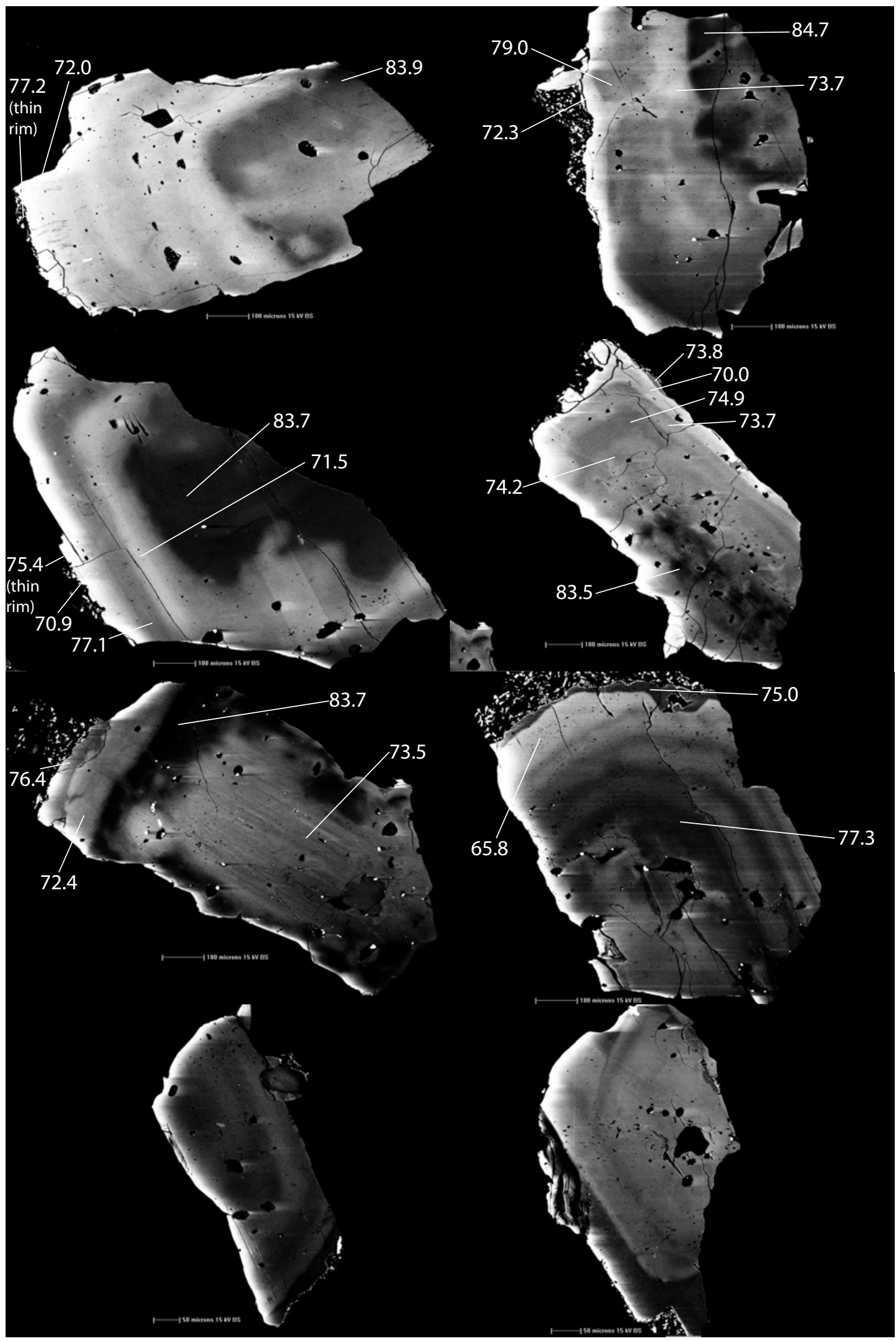

Figure 2.5: BSE images of clinopyroxene crystals from the 1870 lava flow, showing some of the range in zoning and textures. Numbers indicate $\mathrm{Mg} \#$ of analysed zones, with lines directing to where the measurement was made. 


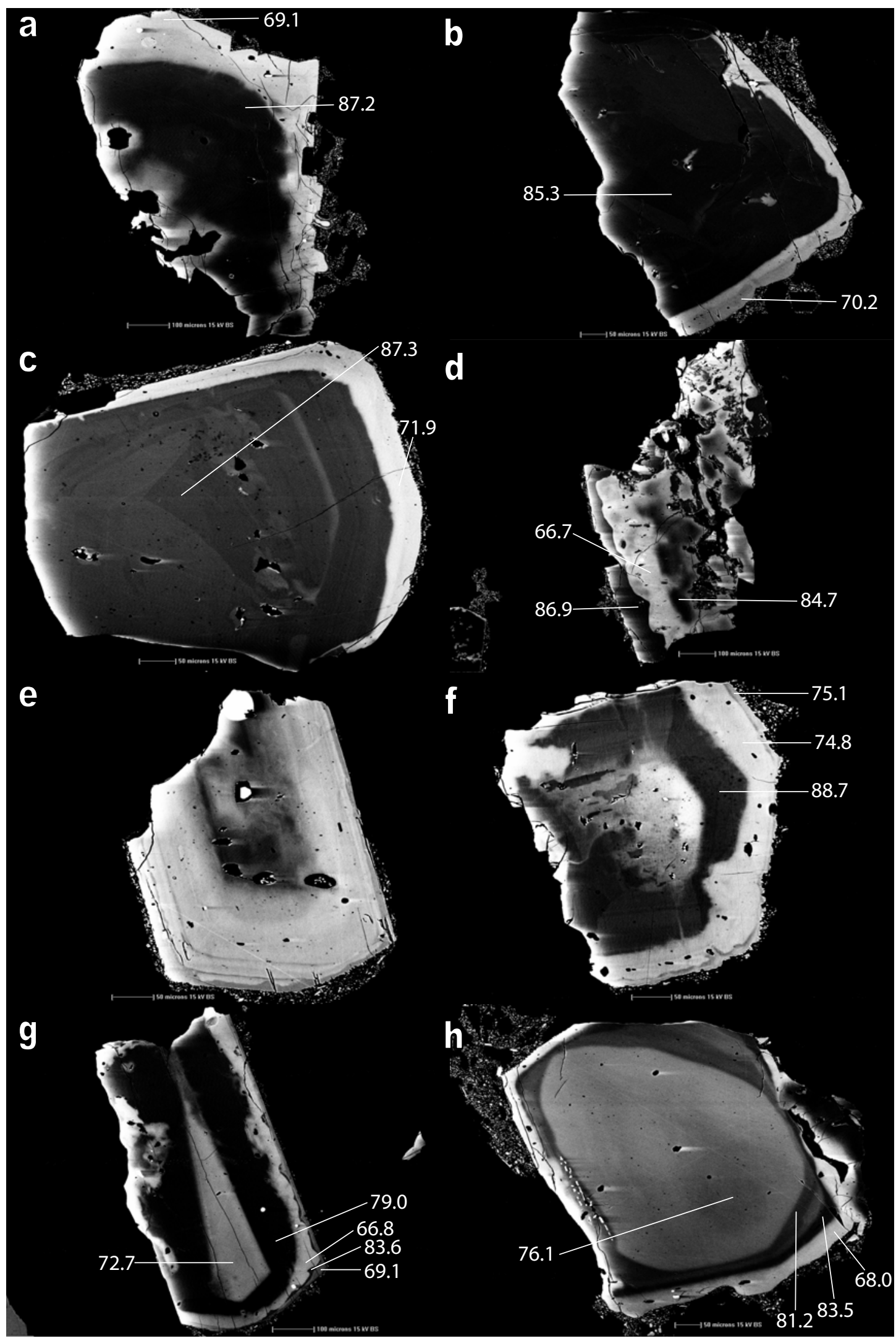

Figure 2.6: BSE images of clinopyroxene crystals from the 1949 lava flow, with Mg numbers given where measured. Crystals with zoning patterns similar to those of $\mathrm{a}, \mathrm{b}$ and $\mathrm{c}$ appear to be the most common, however, many varieties occur as demonstrated by the remaining images. 


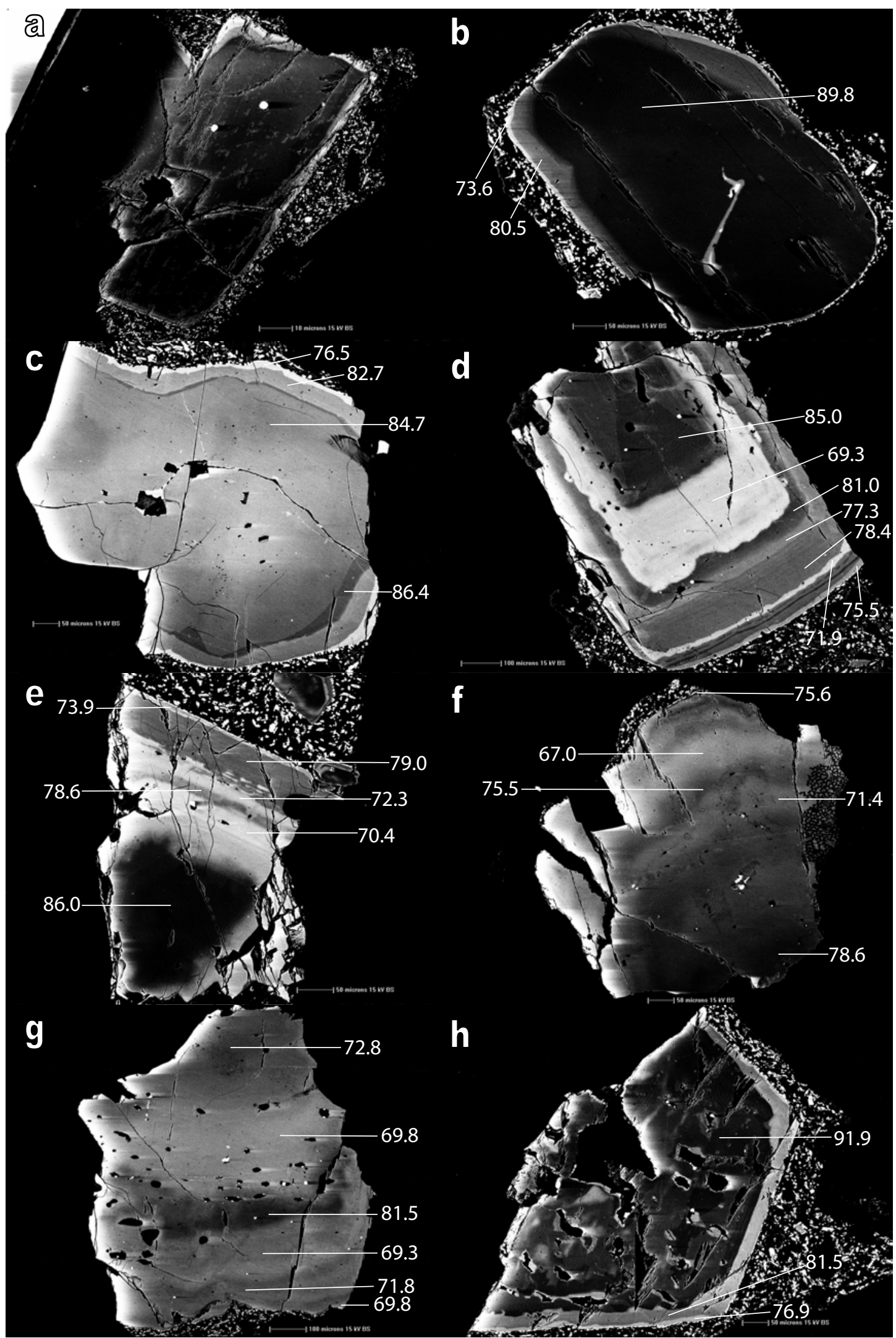

Figure 2.7: BSE images of clinopyroxene crystals from the 4th June 1954 lava flow, with Mg\# given where measured. Particular features are discussed in the text.

CHAPTER 2: Fieldwork and Petrology 
30th June 1954: Zoning examined in the clinopyroxenes from this lava flow (Figure 2.8) was relatively simple. Crystals generally have a Mg-rich core or inner zone of Mg\# 8088 followed by a zone or several zones of more Fe-rich composition (Mg\# 65-73), with a final thin rim returning to a more Mg-rich composition (Mg\# 75-82). In some crystals there is a core within the Mg-rich inner zone that is of a more Fe-rich composition, and in other crystals an originally Mg-rich core has been altered to more Fe-rich compositions by abundant melt inclusions.

14th July 1954: The most common zoning pattern of those 14th July 1954 clinopyroxenes examined was relatively simple (Figure 2.9a), consisting of a Mg-rich core (Mg\# 85-87) surrounded by a zone of Mg\# 81-83, sometimes with a further more Fe-rich rim of Mg\# 75-78. In some crystals there is a zone adjacent to the core that has a more magnesian composition than the core material. Another common crystal population (Figure 2.9b) is defined by a distinct Mg-rich core (Mg\# 80-82) against considerably more Fe-rich material (Mg\# 65-69), with a very thin magnesian rim of similar composition to the previous population (Mg\# 73-79). Other crystals show more complex zoning patterns (Figure 2.9c-d). One of the particularly distinctive features of the 14th July lava flow is that it also contains a population of clinopyroxene crystals which have experienced a marked rapid dissolution event near the rim (Figure 2.9e-f). This texture occurs against an inner zone of Mg\# 71-72 with patches of crystal on the outer edge of the zone that have $\mathrm{Mg \#}$ as high as 85-87, indicating that after growing quite an evolved zone the clinopyroxene was then immersed into a particularly mafic melt. Crystallisation of a clean outermost rim of Mg\# 82-85 has then occurred. A separate set of 14th July 1954 crystals show a more saw-toothed texture to a distinct Ferich zone (Figure 2.9g-h), which has Mg\# 66-72 against a zone of Mg\# 79-84. 


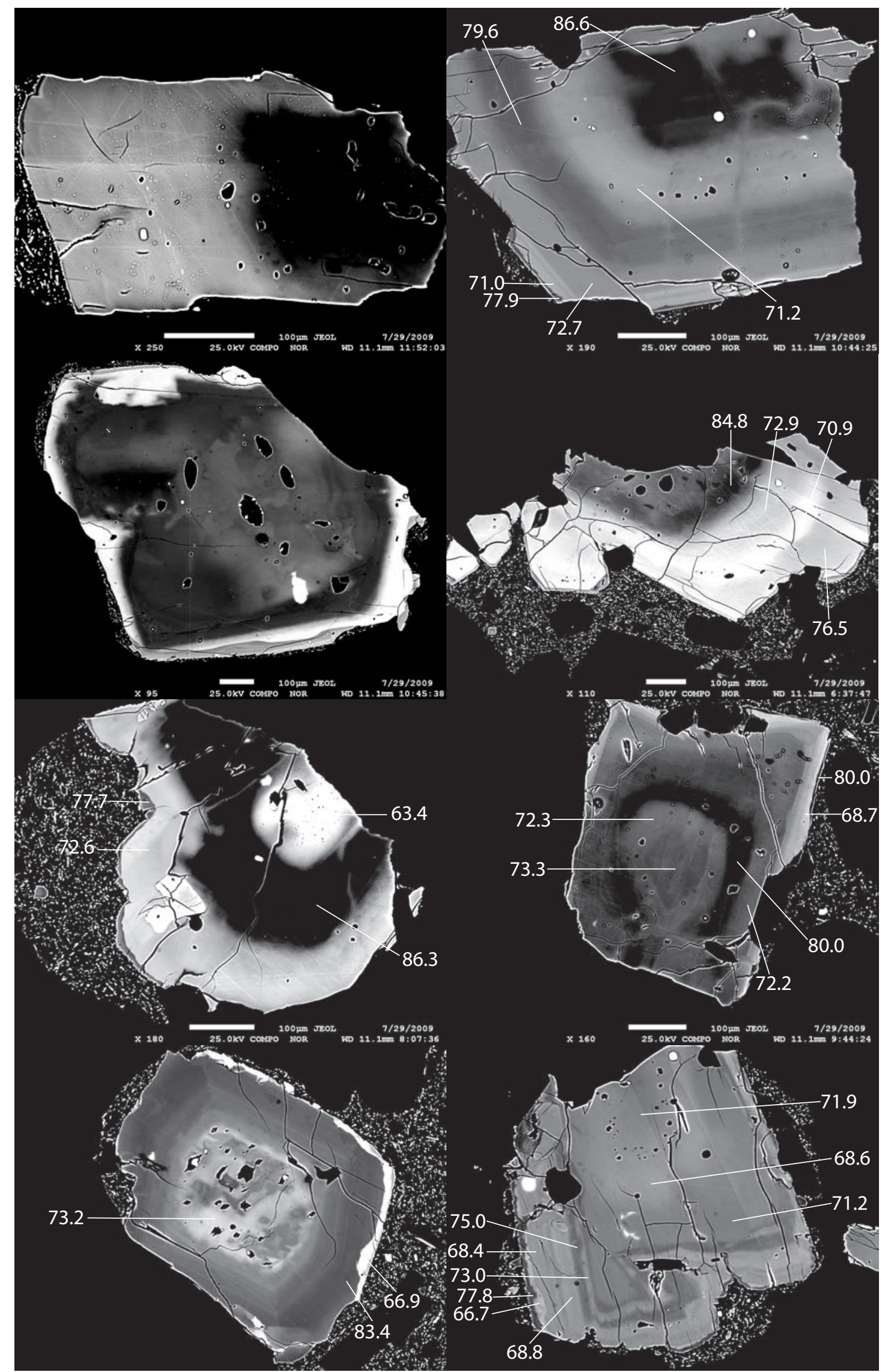

Figure 2.8: BSE images of clinopyroxene crystals from the 30th June 1954 lava flow, with Mg\# calculated for zones given where measured. 


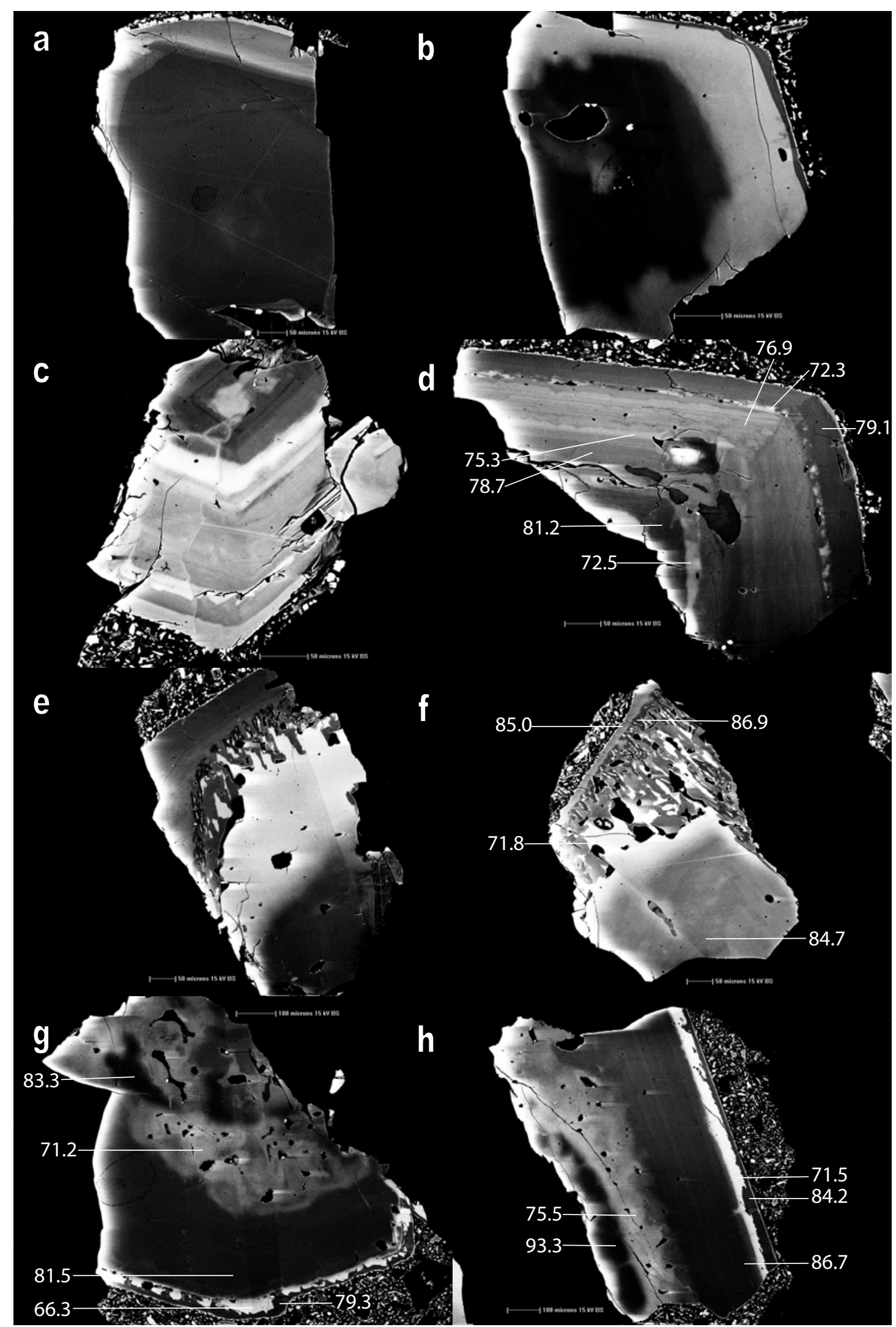

Figure 2.9: BSE images of clinopyroxene crystals from the 14th July 1954 lava flow, with Mg\# labelled where measured. 
29th July 1954: Clinopyroxenes from the 29th July 1954 lava flow often possess a Mgrich core (Mg\# 84-87) containing abundant melt inclusions which have altered the chemistry of the area around them. This core is then followed by a more Fe-rich zone (Mg\# 69-73). Some crystals then have a wide zone (which in some cases is the rim) of Mg\# 83-86. A population of crystals also have cores of orthopyroxene (Figure 2.10) that are relatively Fe-rich (Mg\# 72-75).

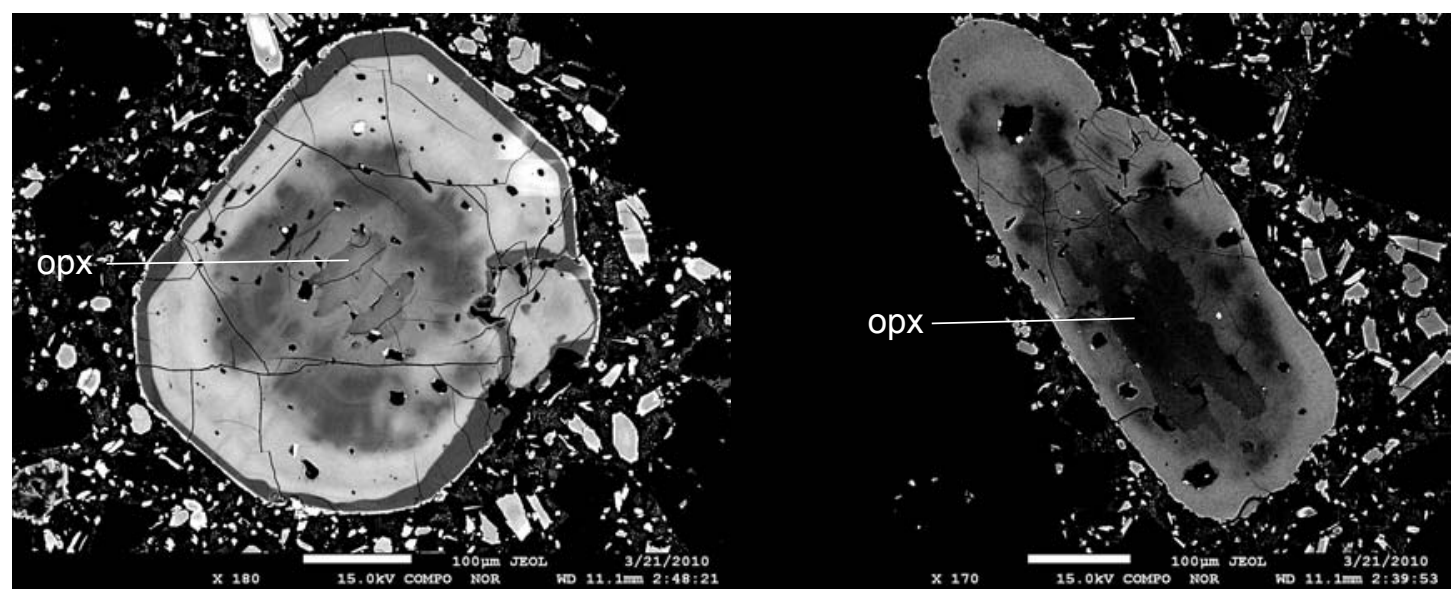

Figure 2.10: BSE images of clinopyroxenes from the 29th July 1954 lava flow with inclusions of orthopyroxene in the cores. In the picture on the left there are two patches of orthopyroxene which lie within a more Fe-rich zone of the Mg-rich core, probably due to diffusive exchange between the Fe-rich orthopyroxene crystals and the originally Mg-rich core.

18th August 1954: The 18th August lava flow clinopyroxenes that were examined predominantly display quite simple zoning similar to the first population described for the 14th July lava flow, that have spent the majority of their growth in relatively mafic melt (Figure 2.11). Cores have Mg\# 84-91, sometimes followed by a zone (which, when it occurs, is more mafic than the core) of Mg\# 88-90, mantled by a wide rim or zone of material with Mg\# 82-86. Sometimes this is followed by a thinner rim of Mg\# 76. The 18th August flow also contains a population of crystals that have experienced rapid dissolution at the edge similar to the 14th July crystals, however the texture is slightly different and the original Fe-rich zone appears to have been even more Fe-rich, with material of Mg\# $\sim 83$ forming a rim on material of Mg\# 65 . 


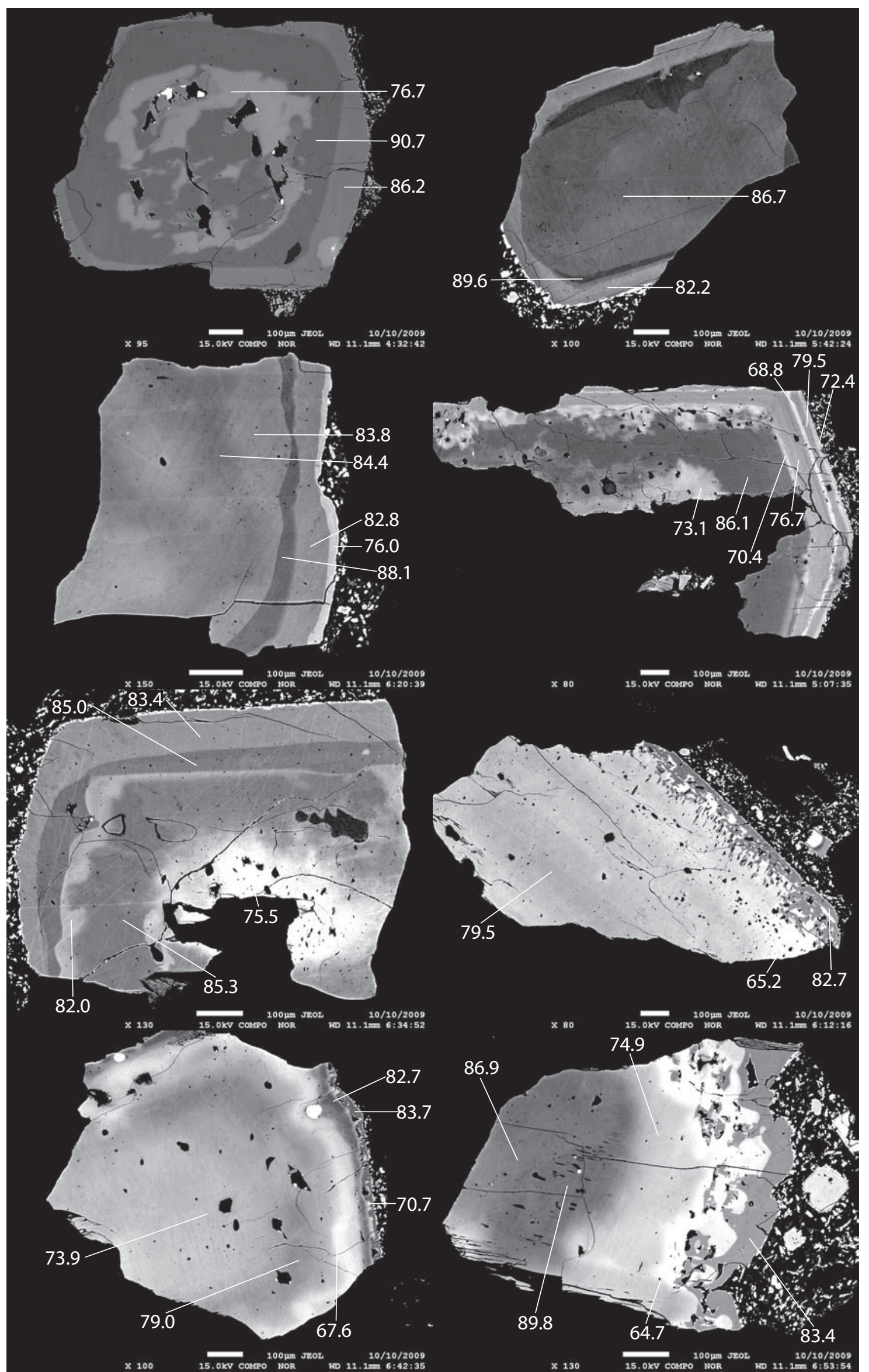

Figure 2.11: BSE images of clinopyroxene crystals from the 18th August 1954 lava flow, with Mg\# labelled where measured. 
16th September 1954: Clinopyroxenes examined from this lava flow generally have cores of Mg\# 81-87 followed by an Fe-rich zone of Mg\# 65-69, and a further Mg-rich zone/s of Mg\# 82-85 and/or Mg\# 72-77 before the rim (Figure 2.12a-d). The outermost rims are too thin to analyse on many crystals, but where analysed were Fe-rich (Mg\# 65-69) and occasionally composed of orthopyroxene rather than clinopyroxene. Some crystals also exhibit a dissolution texture near the rim similar to that observed in the 14th July and 18th August flows, with an outer zone of Mg\# 83-85 against an inner zone of Mg\# 68-70 (Figure 2.12e-f). The outermost rim of these crystals is also Fe-rich, although too thin to analyse.

18th September 1954: The most common clinopyroxene crystal zoning pattern of those examined from the 18th September 1954 lava flow consists of cores of Mg\# 82-90 surrounded by a more Fe-rich zone or zones that drop as low as Mg\# 67-69 before a thin final rim of Mg\# 73-80 (Figure 2.13a-f). In many cases, the core chemistry has been affected in places by abundant melt inclusions. There is also a less common population of crystals (Figure 2.13g) that are almost entirely of mafic composition (Mg\# 89-92) with a very thin rim of Fe-rich material (Mg\# 67-68). A further population of crystals (Figure 2.13h) is characterised by a core of $\mathrm{Mg \#} \sim 87$, followed by a series of very fine zones ranging from $\mathrm{Mg \#} \mathrm{80-86.}$

1975: Clinopyroxene crystals from juvenile material erupted in 1975 generally have cores of Mg\# 84-91. This core is often mantled by more Fe-rich zoning (Mg\# 67-72) before another band of Mg\# 81-87. Further Fe-rich zoning (Mg\# 66-73) then occurs prior to the rim. Rim composition appears to be highly variable, although this may partly be due to sectioning effects, with some crystals having rims with Mg\# 65 (Figure 2.14a-b), others Mg\# 73-75 (Figure 2.14c-d), and yet other crystals having rims of Mg\# $\sim 80$ (Figure 2.14e-f). In addition, some 1975 clinopyroxenes show a dissolution texture toward the rim not unlike that seen in the 14th July, 18th August and 16th September 1954 lava flows, with the difference that the rim that has formed on the texture is 
considerably more Fe-rich than the material that forms the texture (Figure 2.14g). A small subset of the clinopyroxenes also have a highly altered core (Figure 2.14h).

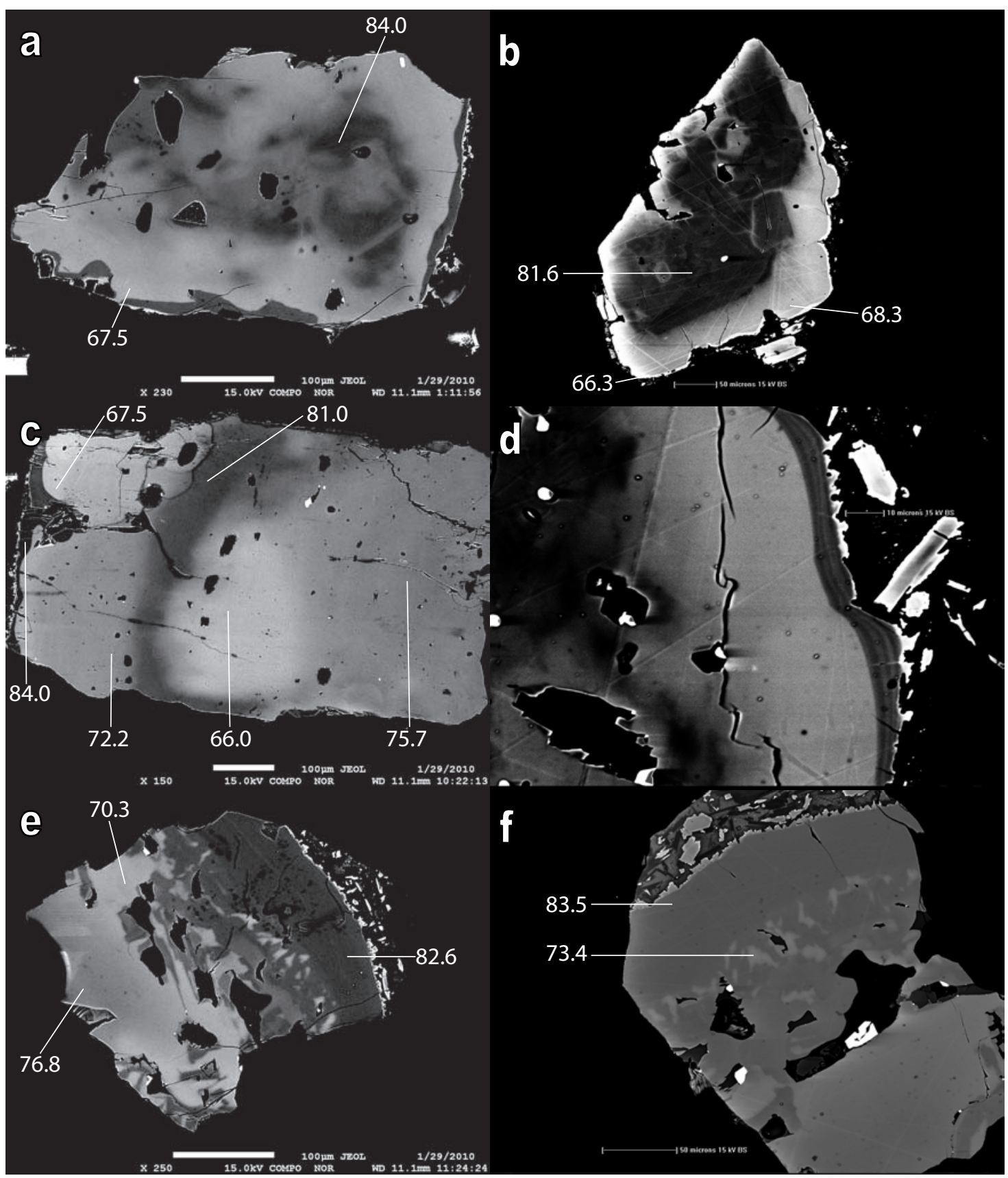

Figure 2.12: BSE images of clinopyroxene crystals from the 16th September 1954 lava flow, with $\mathrm{Mg} \#$ given where measured. 


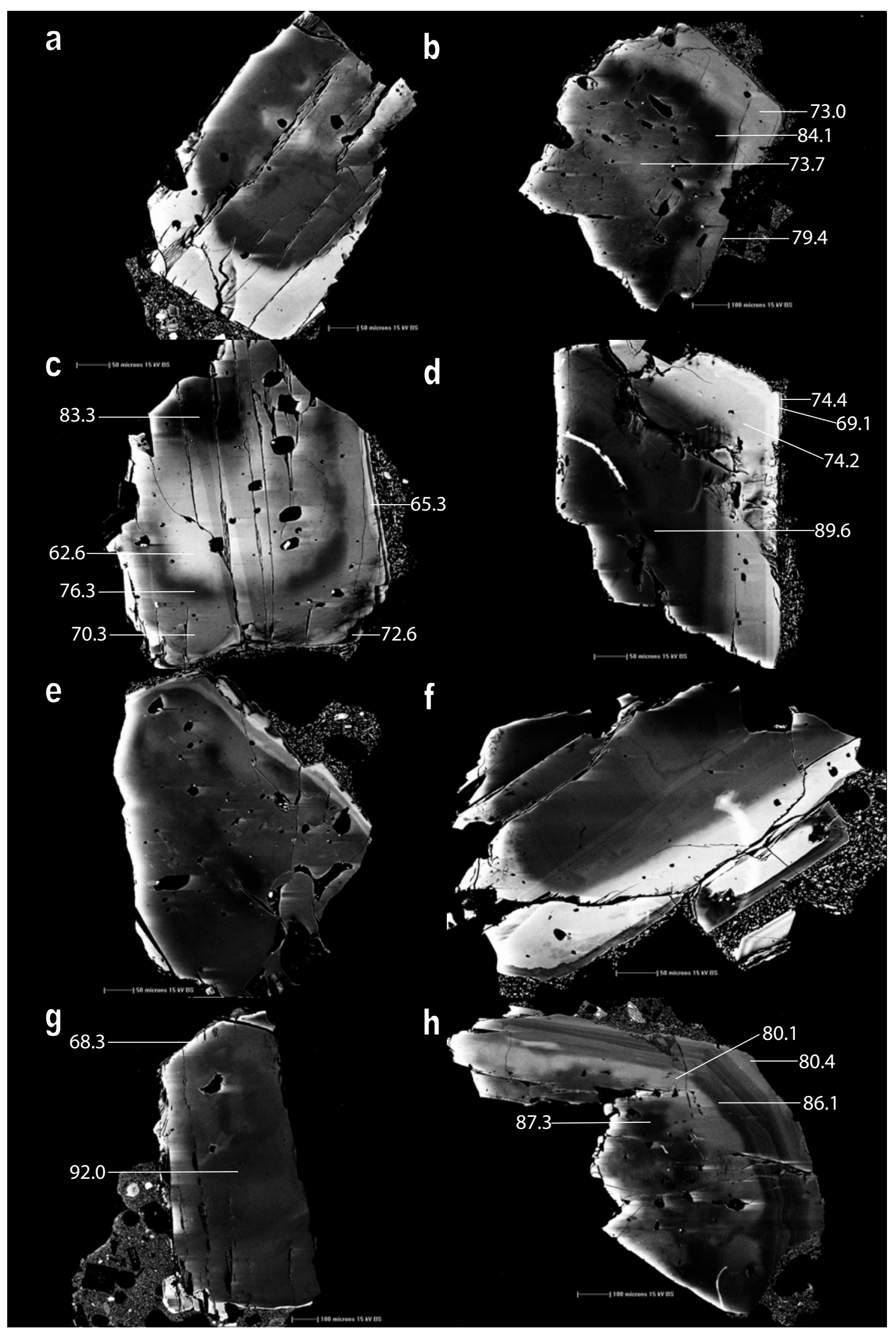

Figure 2.13: BSE images of clinopyroxene crystals from the 18th September 1954 lava flow, with $\mathrm{Mg} \#$ given where measured. 

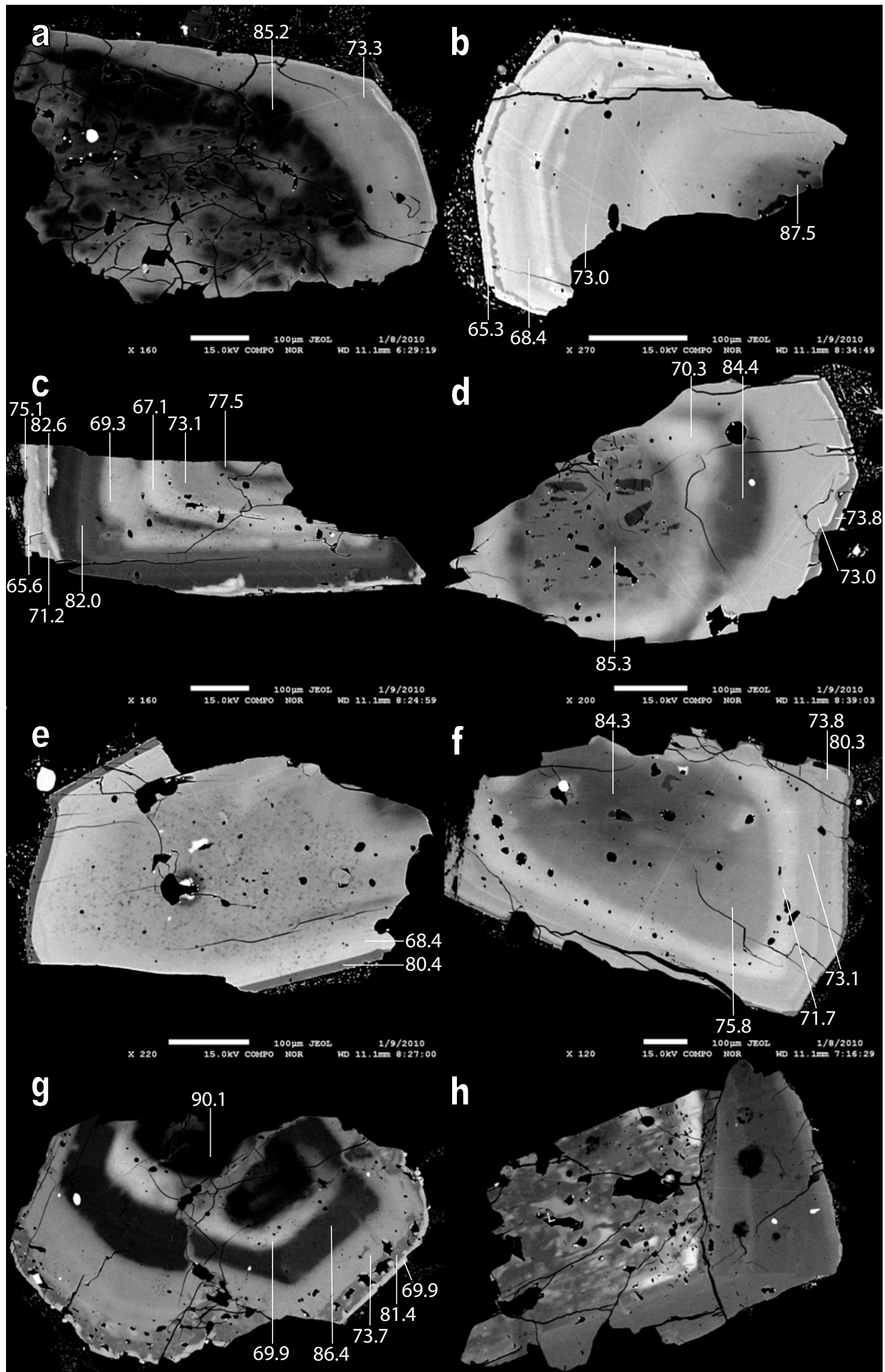

$100 \mathrm{pm}$ JEOL $1 / \mathrm{B} / 2010$

15. OKV COMPO 100 MOR TEOL $11 / 8 / 2010$

Figure 2.14: BSE images of clinopyroxene crystals from juvenile material erupted in the 1975 block-and-ash flow, with Mg\# given where measured. 


\subsubsection{Orthopyroxene}

Orthopyroxene occurs as individual crystals up to $2.4 \mathrm{~mm}$ long, glomerocrysts, microlites, reaction rims on olivine and occasionally as rims on some clinopyroxene crystals. It also occurs as secondary inclusions in the cores of some clinopyroxene crystals, as shown in Figure 2.10.

Those crystals that occur as reaction rims around olivine show a gradational increase in magnesium toward the contact with the olivine, where they are generally quite Mg-rich (Mg\# 75-85), relating to the core chemistry of the host olivine. Further from the olivine, Mg\# of the orthopyroxene can drop to as low as Mg\# 66. There is then often further zoning at the edges of the reaction rim, suggesting there have been further changes in the magmatic conditions following the formation of the reaction rim (Figure 2.21).

Individual orthopyroxene crystals in each lava flow show a wide variety of zoning patterns and textures, but many of these crystal-types were found to recur in similar forms throughout the suite of historical lava flows. One of the most common zoning patterns observed (Figure 2.15) consists of a very diffuse Mg-rich core (Mg\# 76-82) surrounded by a zone of Fe-rich material (Mg\# 61-68), followed by a sharp thin rim of an intermediary composition (Mg\# 67-76). The core is frequently riddled with abundant melt inclusions that have altered the surrounding chemistry.

Another common orthopyroxene zoning pattern observed throughout the historical lava flows is an almost entirely Mg-rich crystal with a sharp contrast to a very thin Fe-rich rim (Figure 2.16). Cores analysed were of Mg\# 77-83, and Fe-rich rims were Mg\# 6164 with the exception of the 1949 analysis, which had Mg\# 68.

A large number of the orthopyroxenes also exhibit a dissolution texture similar to that described for the clinopyroxenes (Figure 2.17). The Mg-rich outer part of the texture generally has Mg\# 78-81 and is against an inner Fe-rich zone of Mg\# 64-67. However, in the 1975 crystal that was analysed (Figure 2.17h), the Mg-rich rim is only Mg\# 74 and is against an Fe-rich zone of only Mg\# 60. In the 16th September 1954 sample, a 
rim of Mg\# 70-71 has formed outside the dissolution texture of these crystals (Figure 2.17g).

A further population of crystals has compositions that lie entirely within the range Mg\# 68-76 for all zoning (Figure 2.18). This is the same range shown just in the rims of the first population described. However, there is no clear size difference between this population of crystals and the first population to suggest that they may have grown in the short interval during which the first population acquired their rims.

Three orthopyroxenes with anomalously Fe-rich (Mg\# 45-54) cores were found, one from the 1870 lava flow and two from the 18th September 1954 lava flow (Figure 2.19). It is probable that crystals like this occur in the other historical lava flows, but were not identified due to their scarcity and the small number of crystals investigated from each flow. These cores also have anomalously low Ca contents and follow different geochemical trends to the rest of the data (see Chapter 3), indicating that they are most likely to be xenocrysts that have then been used as a base for further crystal growth in the magma system. 


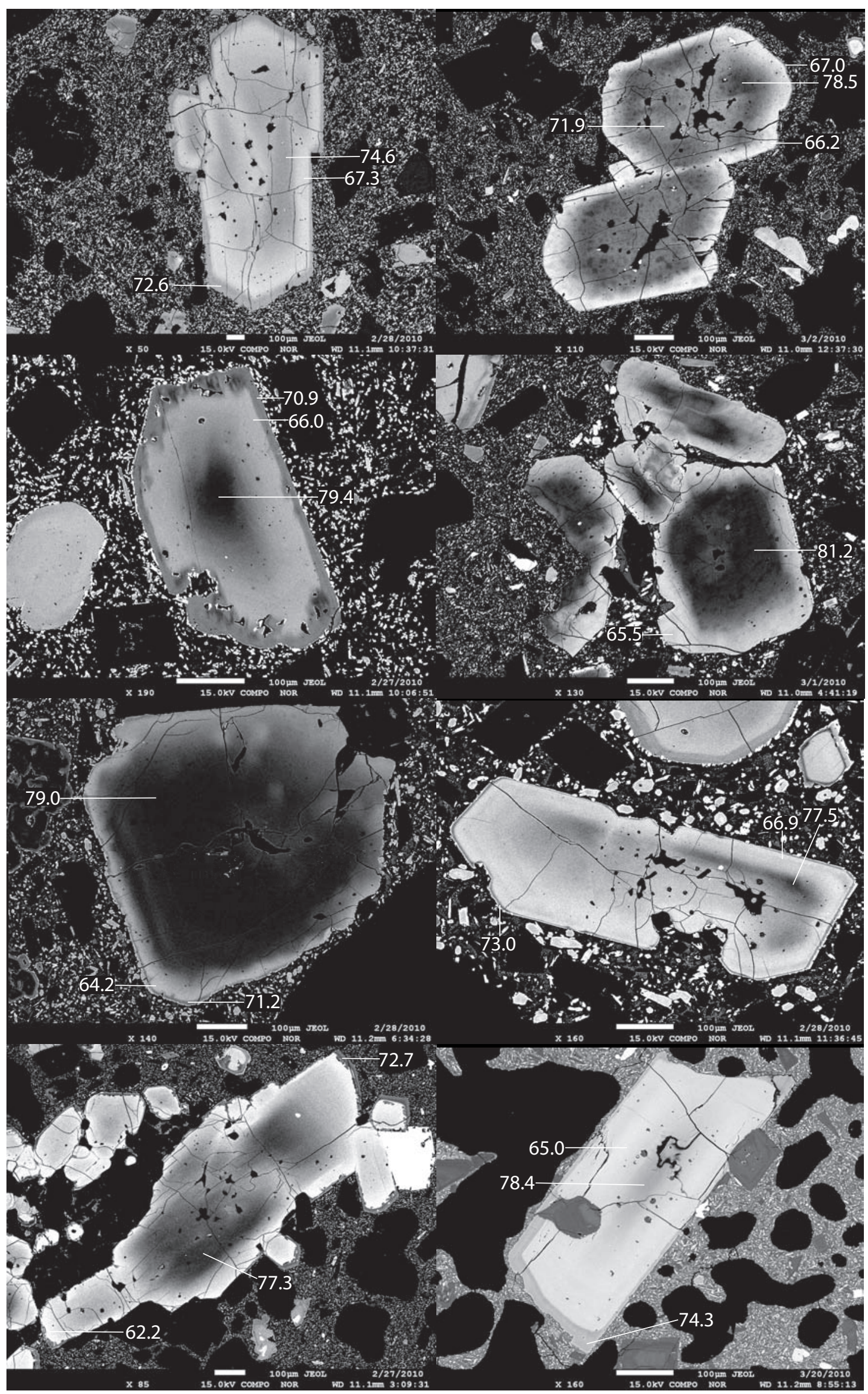

Figure 2.15: BSE images of orthopyroxene crystals showing relatively simple zoning with a diffuse Mg-rich core mantled by an Fe-rich zone, with a further sharp rim of intermediary composition. Mg\# is labelled where measured. 


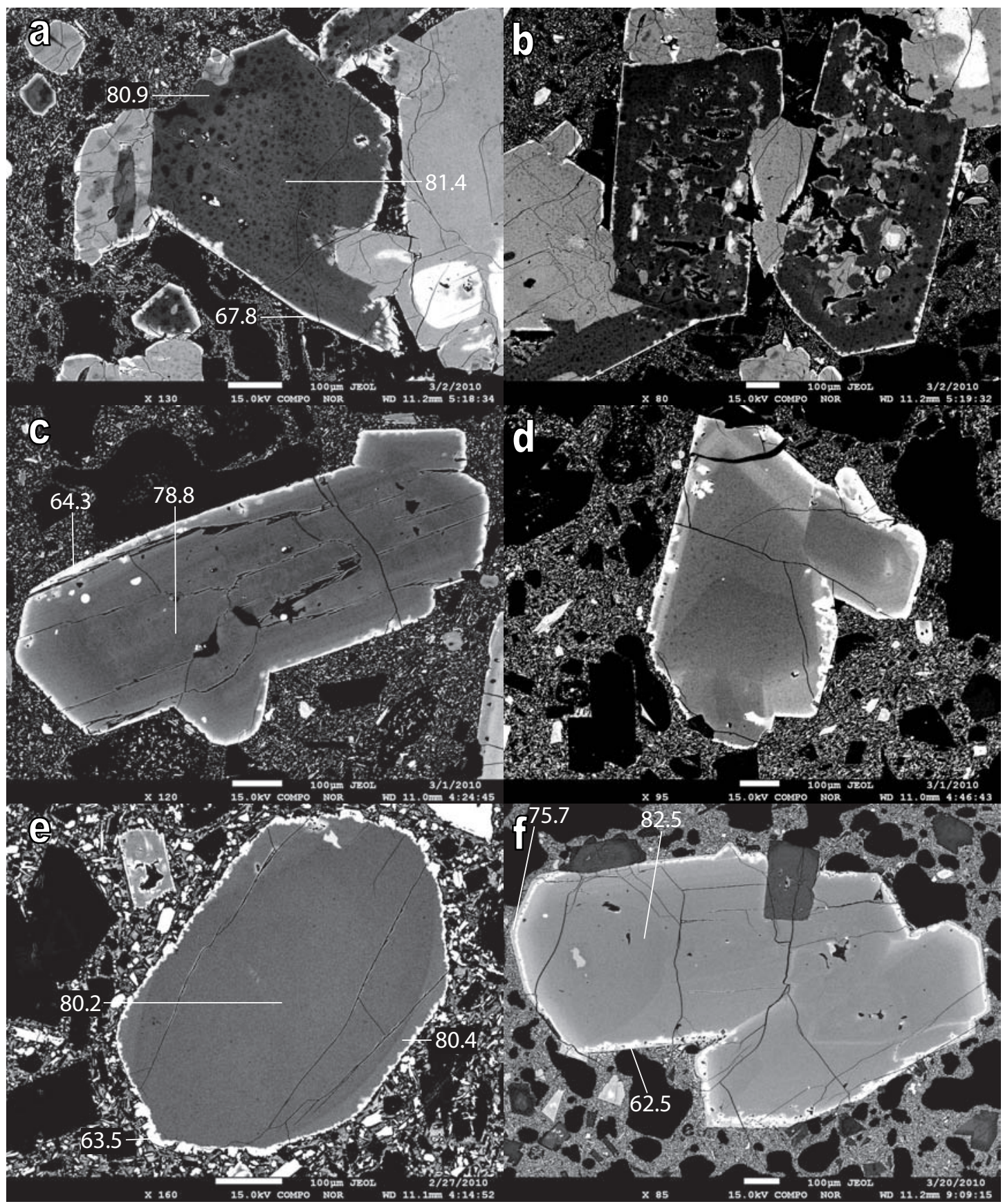

Figure 2.16: Orthopyroxene crystals with Mg-rich cores surrounded by very thin Fe-rich (Mg\# 61-68) rims. a-b: 1949 lava flow, c-d: 30th June 1954, e: 16th September 1954, f: 1975. Mg\# is labelled where measured. 


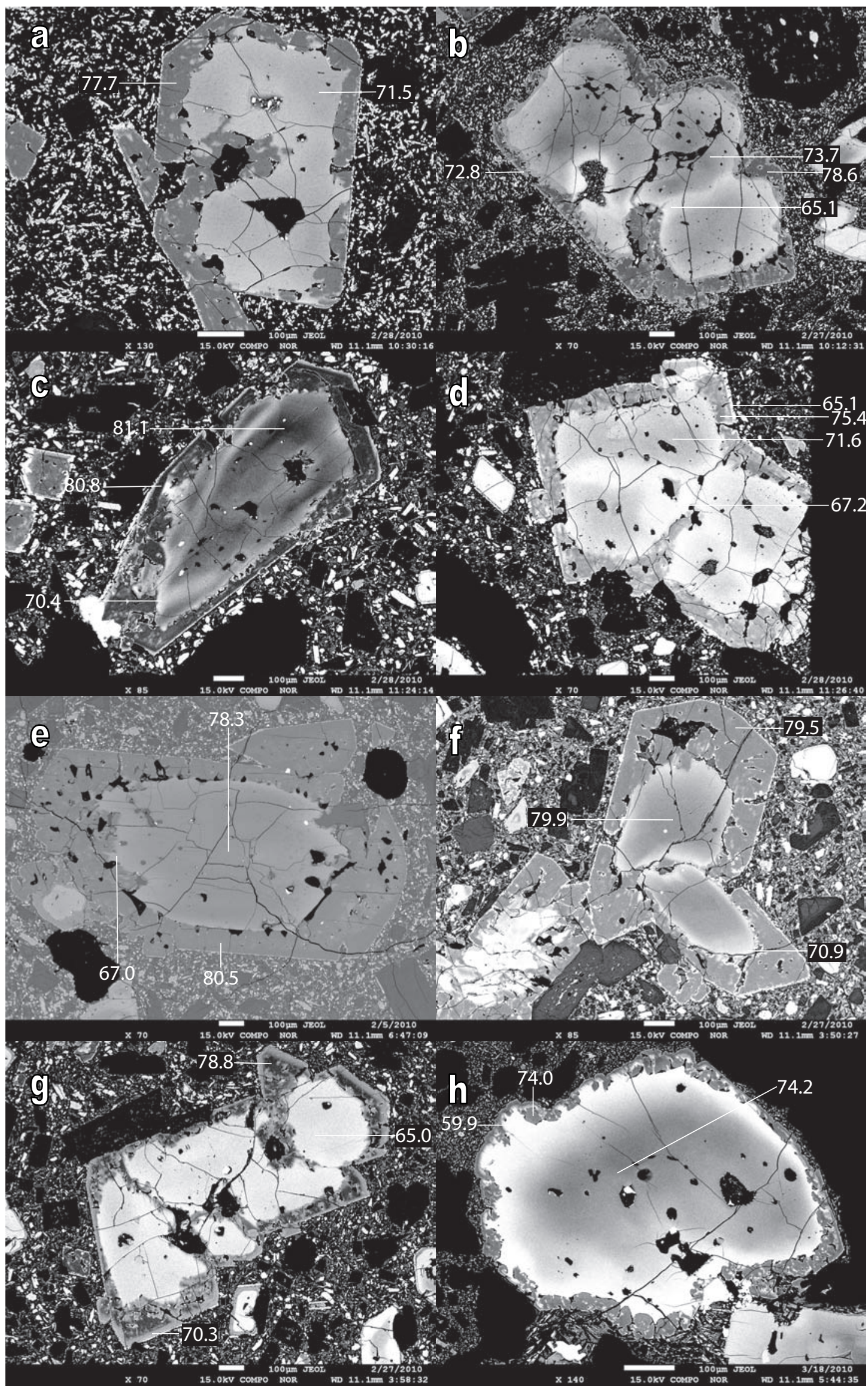

Figure 2.17: BSE images of orthopyroxene crystals exhibiting a dissolution texture near the rim. a: 1870, b: 4th June 1954, c-d: 29th July 1954, e: 18th August 1954, f-g: 16th September 1954, h: 1975. Mg\# is labelled where measured. 


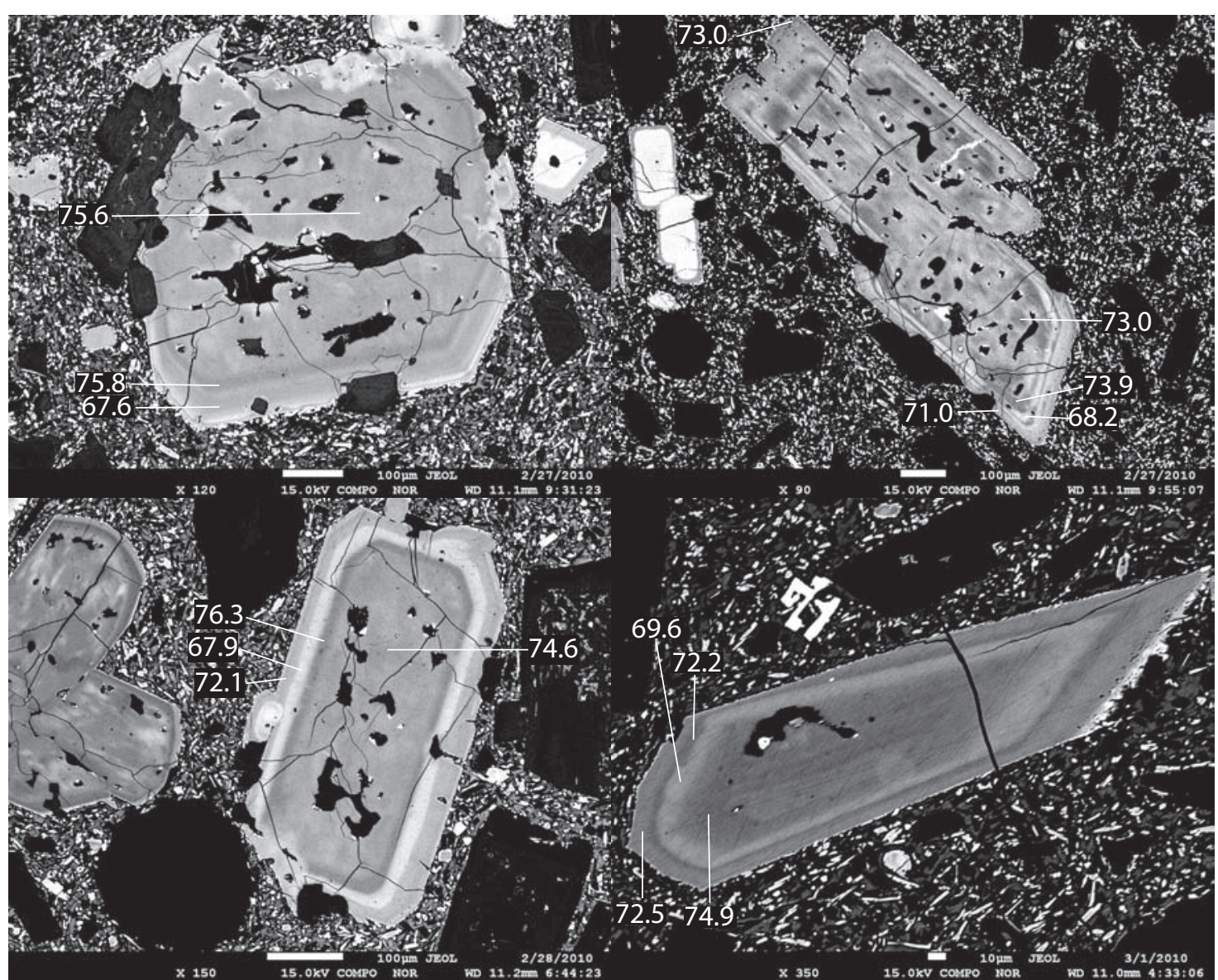

Figure 2.18: BSE images of orthopyroxene crystals that have all zoning within Mg\# 68-76. Mg\# is

labelled where measured.

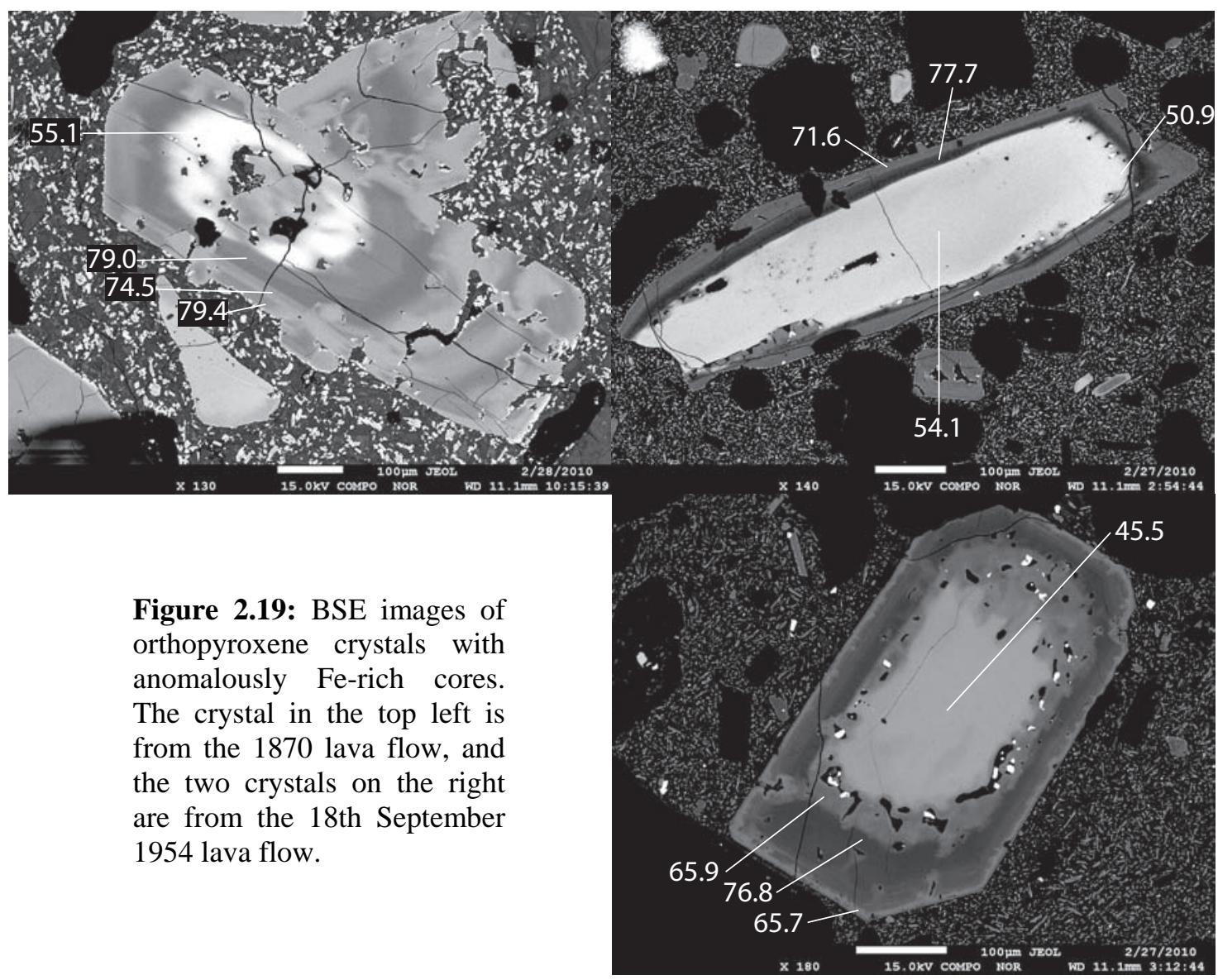




\subsubsection{Plagioclase}

Plagioclase is ubiquitous and abundant throughout both the historical and pre-historical lava flows, occurring as antecrysts, phenocrysts, microlites, and in crystal clots and quartzo-feldspathic xenoliths. Crystals are generally euhedral and range from $\sim 10 \mu \mathrm{m}$ (microlites) up to $2.6 \mathrm{~mm}$ in length, although rare particularly large crystals up to 4.5 $\mathrm{mm}$ can be found. The crystal population is dominated by distinct calcic cores $\left(\mathrm{An}_{80-92}\right)$ mantled by oscillatory zoned sodic rims $\left(\mathrm{An}_{53-74}\right)$. However, crystals that are entirely sodic, have sodic cores or possess multiple distinct (non-oscillatory) zones are not uncommon (Figure 2.20), and some crystals with rims that are more calcic (up to $\mathrm{An}_{81}$ ) than adjacent sodic material also occur. Sodic cores vary as widely in anorthite content as do sodic rims, with no clear relationship to rim composition.

Sieve texturing occurs in $\sim 40-90 \%$ of the plagioclase crystals within any one lava flow. The 1870 lava flow appears to have a higher percentage of sieved crystals than the later historical flows, although no clear pattern is discernible over the course of the historical eruption period. Sieving is only seen in calcic regions of the crystals, but it is unclear whether the region was originally calcic or has been recrystallised during the event which caused the sieving. Anhedral titanomagnetite and Fe-sulfide inclusions in plagioclase are common, but the titanomagnetite occurs only as a secondary feature which has crystallised from melt inclusions in sieve textured regions of the crystals.

Figure 2.20 (over leaf): BSE images of plagioclase crystals from the historical Ngauruhoe lava flows to illustrate the range in textures that occur. Crystals similar to $\mathbf{a}$ and $\mathbf{b}$, with sieved calcic cores and sodic rims, are the most common. a: Crystal from 18th August 1954 flow with a distinct calcic core that is sieved with sodic plagioclase and melt inclusions in its centre, surrounded by a wide oscillatory zoned sodic rim b: Almost entirely calcic and heavily sieve textured plagioclase from 1870 lava flow with thin sodic rim. c: Crystal from 1870 lava flow that is entirely oscillatory zoned, with transition from core to rim that is gradual rather than the abrupt change seen in most crystals. d: Crystal from the 1949 lava flow showing small rounded calcic core in a predominantly sodic crystal. e: Crystal from 14th July 1954 lava flow showing evidence of at least four distinct environments, changing from a calcic core to a sodic zone, followed by another calcic zone that is highly sieve-textured, before a final sodic rim. f: Crystal from 29th July 1954 lava flow with entirely sodic composition excepting a relatively thin sieved calcic zone adjacent to the rim g: Crystal from 16th September 1954 lava flow that is un-sieved and of entirely sodic composition, despite being just as large as crystals with more complex zoning. h: Crystal from 18th September 1954 lava flow showing trails of calcic material behind melt inclusions that have transgressed into sodic inner zone. Labels on images indicate anorthite contents. 


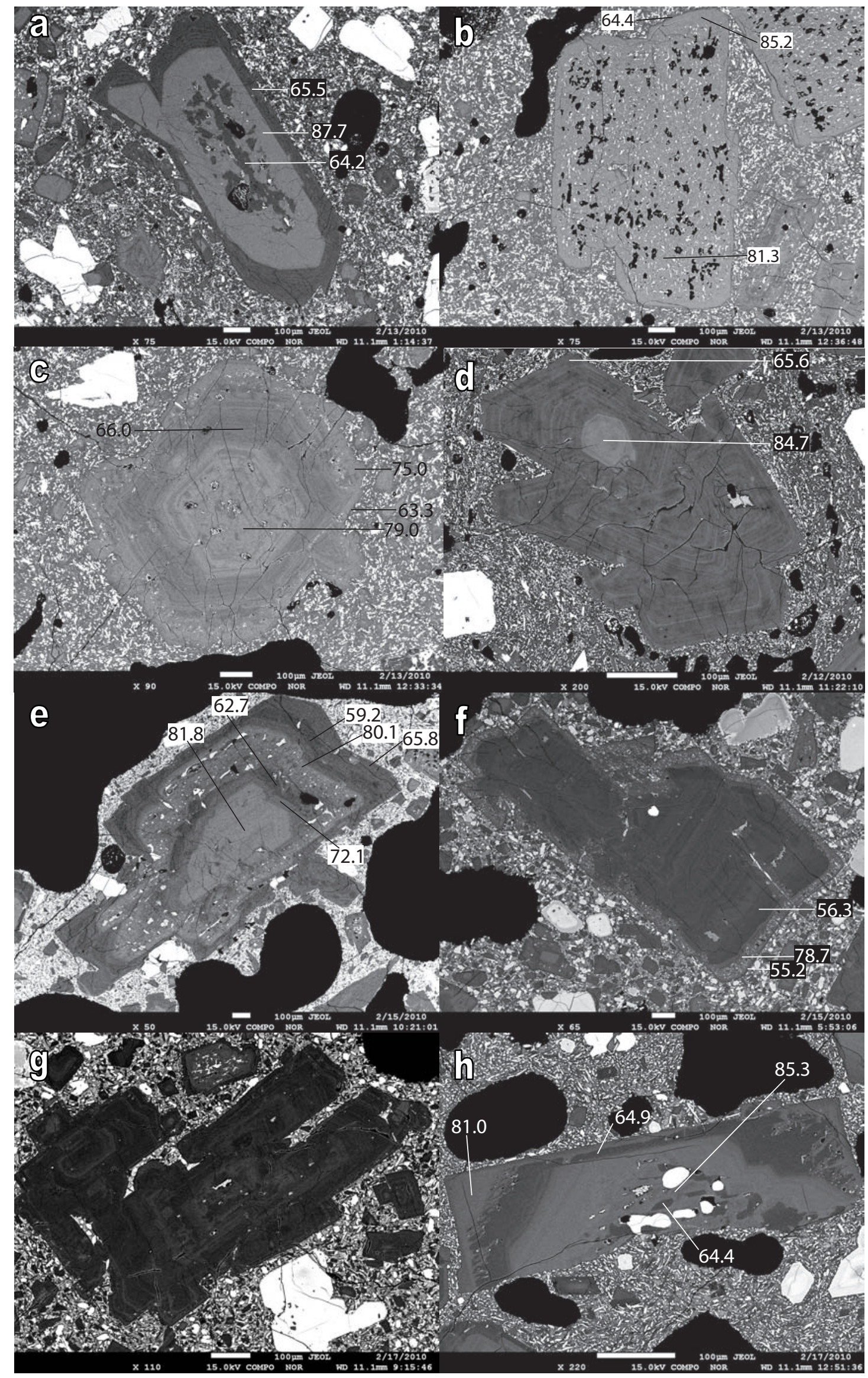




\subsubsection{Olivine}

Olivine crystals are present in minor amounts in all lava flows, but show significant evidence of disequilibrium with the final melt (Figure 2.21). They occur both as individual crystals and as glomerocrysts, and are nearly always highly resorbed and encased in a symplectitic reaction rim of orthopyroxene \pm titanomagnetite. A number of olivines also have plagioclase and occasionally clinopyroxene adhered to the reaction rim, forming a small crystal clot. In addition, some crystals show evidence of diffusive re-equilibration of $\mathrm{Fe}$ and $\mathrm{Mg}$ with both the surrounding melt and melt inclusions. Where present, titanomagnetite occurs as a vermicular formation that is coarser further away from the olivine and finer where directly adjacent to the crystal edge, sometimes extending into the crystal along fractures. Reaction rims vary greatly in size both within and between samples. In the three most Mg-rich olivines $\left(\mathrm{Fo}_{76-77}\right)$ analysed from the 1975 lava flow, no reaction rim is present whatsoever, despite other olivines in the same thin section having particularly large reaction rims. This may indicate that the crystals have been introduced into more silicic melt at different times. Orthopyroxene reaction rims that mantle more Fe-rich olivines $\left(\mathrm{Fo}_{60-72}\right)$ are often zoned, with a distinct Mg-rich outermost rim, or in some cases multiple zones, present. This zoning only occurs at the outermost parts of the reaction rim where it would be able to interact with new melts, indicating that following formation of the reaction rim the olivine has experienced one or more further episodes of melt disequilibrium prior to its eventual eruption. Mineral inclusions hosted within olivine include chrome spinel, titanomagnetite, Fe-sulfides, and rare ilmenite. 


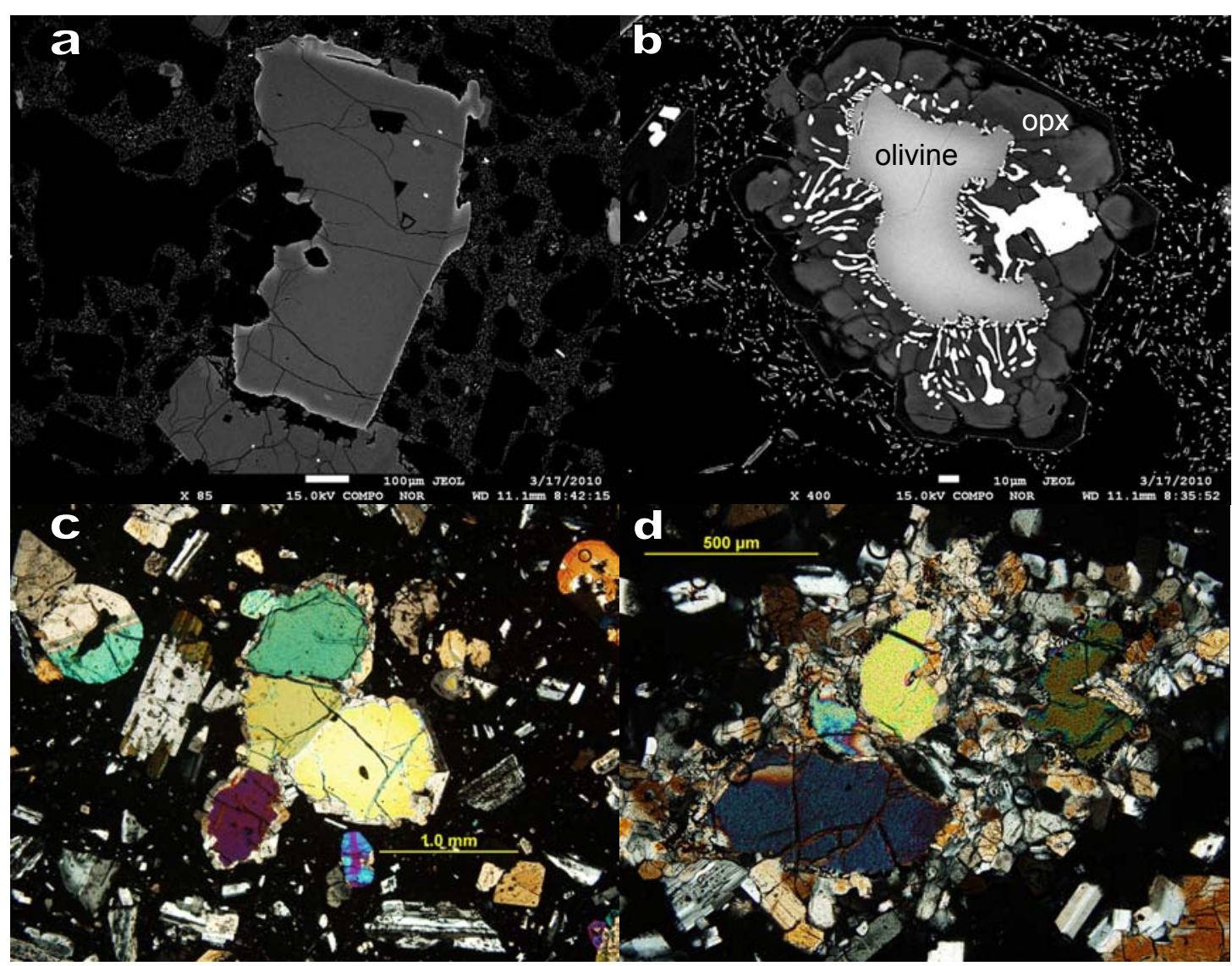

Figure 2.21: Images of olivine crystals from the historical Ngauruhoe lava flows to illustrate some of the range in textures observed. a: BSE image of an olivine with no reaction rim from the 1975 lava flow. b: BSE image of a more Fe-rich olivine from the 1975 lava flow, showing a large reaction rim of vermicular titanomagnetite and orthopyroxene, with the orthopyroxene possessing a distinct Mg-rich outermost zone. c: Thin section image of glomerocryst from the 1870 lava flow. d: Olivine crystals from the 1949 lava flow with large reaction rim of vermicular titanomagnetite, orthopyroxene and plagioclase. 


\subsubsection{Fe-Ti oxides}

Inclusions of titanomagnetite and iron sulfides are found throughout all mineral phases. However, titanomagnetite inclusions are anhedral and show evidence of having crystallised from melt inclusions, rather than being primary mineral inclusions (Figure 2.22a). Iron sulfides occur as small round blebs (Figure 2.22b) and suggest that sulfur saturation of the magma system occurred throughout the crystallisation of all mineral phases. The chemical composition of the sulfides was not measured. As well as anhedral titanomagnetite, olivine crystals have inclusions of chrome spinel (Figure 2.22c) and rare ilmenite (Figure 2.22d), and often have a vermicular titanomagnetite growth at their edges as described in the above section.

Equant titanomagnetite crystals are present as a groundmass phase in many of the lava flows, and also occur as a crystal phase with individual crystals $\sim 20-100 \mu \mathrm{m}$ across. The individual crystals are not particularly common, only a few grains were found under the microprobe per $20 \times 40 \mathrm{~mm}$ thick section. Rare crystals of anhedral low-Ti magnetite (Figure 2.22e) and hercynitic spinel (Figure 2.22f) can also be found, as discussed in Chapter 3. Where hercynitic spinel occurs it is surrounded by a plagioclase reaction rim and shows a significant ( 30 wt\%) decrease in $\mathrm{Al}_{2} \mathrm{O}_{3}$ and corresponding increase in FeO adjacent to the reaction rim, accompanied by a minor increase in $\mathrm{TiO}_{2}$ and decrease in MgO. The hercynite is possibly sourced from gneissic xenoliths: similar observations of metasedimentary hercynite reacting with silicic melt to form anorthitic plagioclase have been described (van Bergen and Barton, 1984), and earlier authors (Steiner, 1958) have suggested a gneissic origin for the abundant xenoliths found in the Ngauruhoe lavas. 


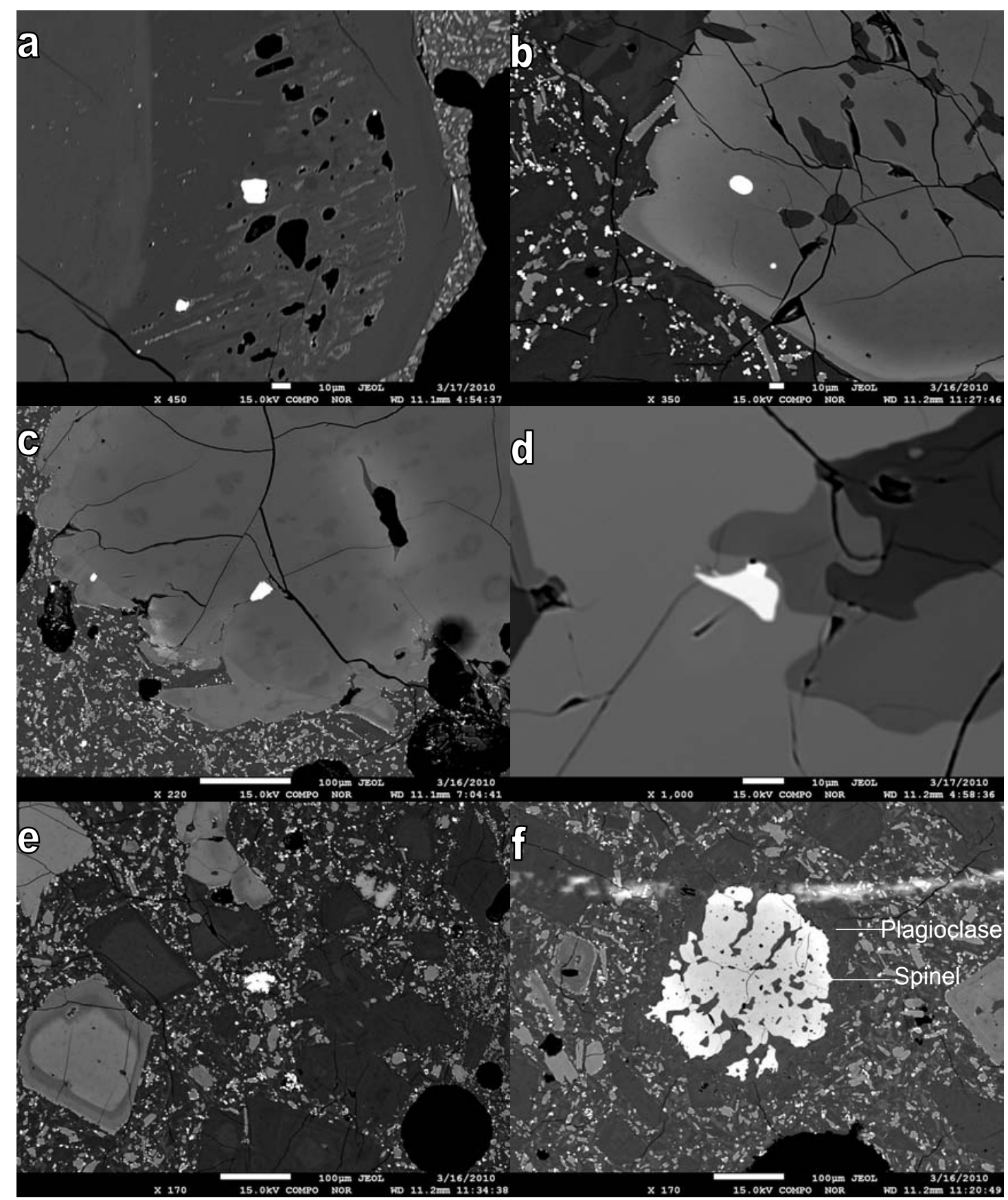

Figure 2.22: BSE images of opaque minerals. a: Titanomagnetite inclusion in a plagioclase crystal from the 1975 eruption. b: Iron sulfide bleb inclusion in an orthopyroxene crystal from the 18th August 1954 flow. c: Chrome spinel inclusion in an olivine crystal from the 1870 lava flow. d: Ilmenite inclusion in an olivine crystal from the 29th July 1954 flow. e: Magnetite (low-Ti) from the 18th August 1954 flow f: Hercynitic spinel with plagioclase reaction rim from the 18th August 1954 lava flow. 


\section{CHAPTER THREE:}

\section{MINERAL CHEMISTRY AND}

\section{DIFFUSION MODELLING RESULTS}

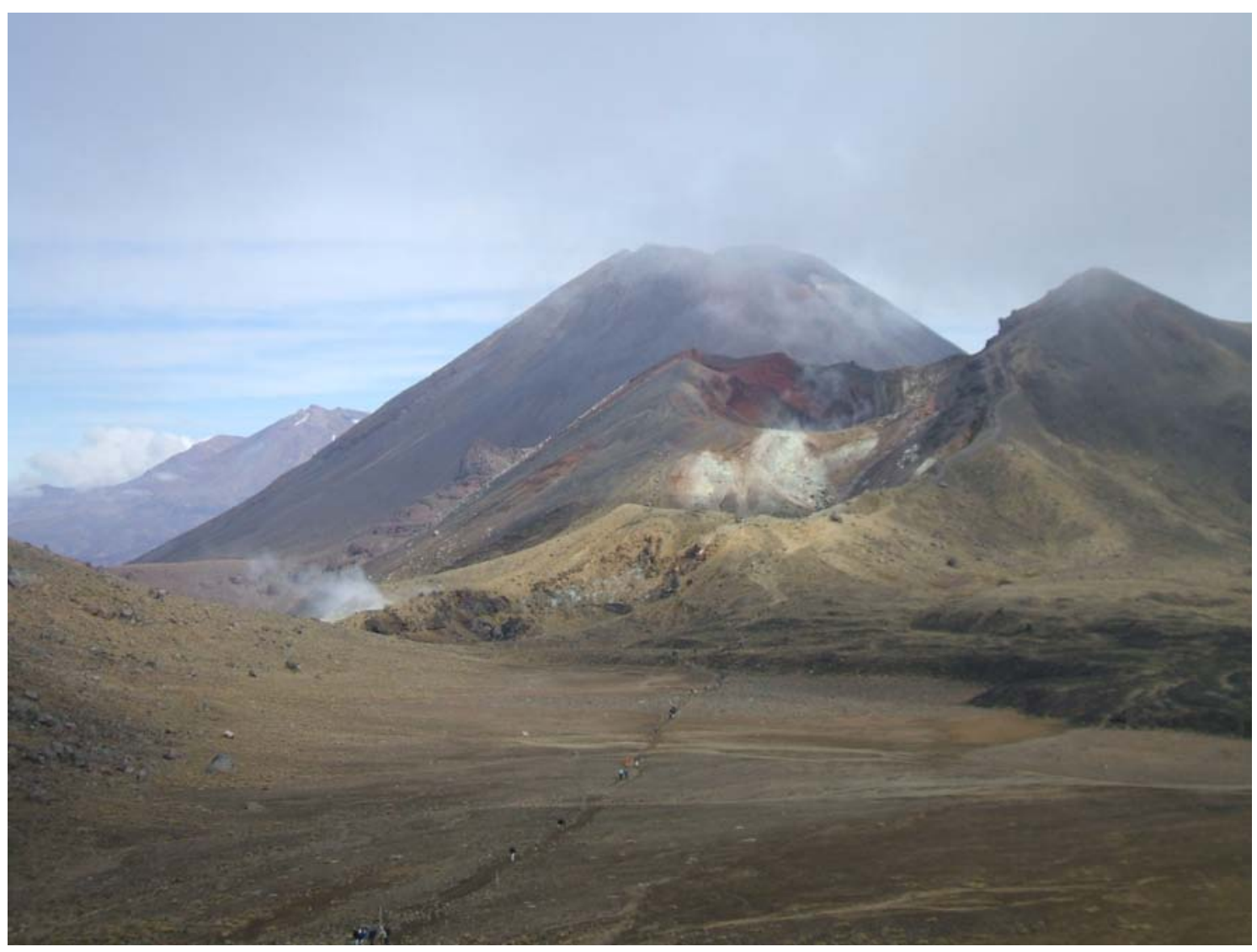

Plate 3: Mt Ngauruhoe (centre) behind the adjacent basaltic cone of Red Crater (foreground), with Mt Ruapehu in the background at the left of the image. 


\subsection{Mineral major element chemistry}

\subsubsection{Clinopyroxene}

Clinopyroxene crystals range from diopside to augite compositions, as shown in Figure 3.1. The distinct zoning patterns described in Chapter 2 are reflected in the Mg\# of the clinopyroxenes, which range from 58-93 (where $\mathrm{Mg \#}=100 \times \mathrm{Mg} /\left(\mathrm{Mg}^{2} \mathrm{Fe}^{2+}\right)$ ) with individual crystals showing variations in $\mathrm{Mg} \#$ as high as 30 (Figure 3.2). Cores are generally more Mg-rich than rims (Figure 3.3), with zones that occur between the core and rim spanning the same range and sometimes extending to even lower $\mathrm{Mg \#}$ than exhibited by either the cores or rims, as exhibited clearly in the 14th July and 18th August 1954 flows.

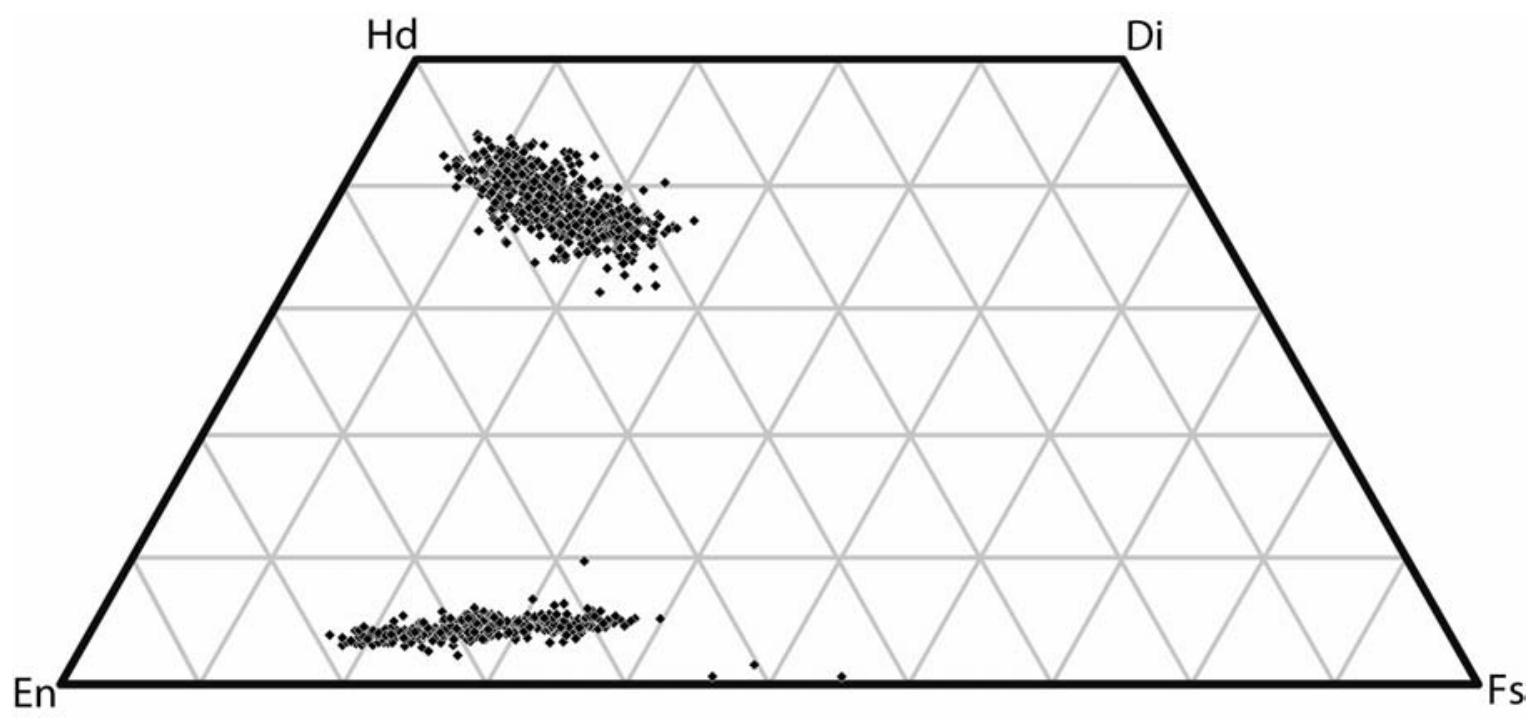

Figure 3.1: Pyroxene quadrilateral diagram showing the range in chemistry shown by the zoning of clinopyroxene and orthopyroxene phenocrysts and antecrysts from the historical Ngauruhoe lava flows. 


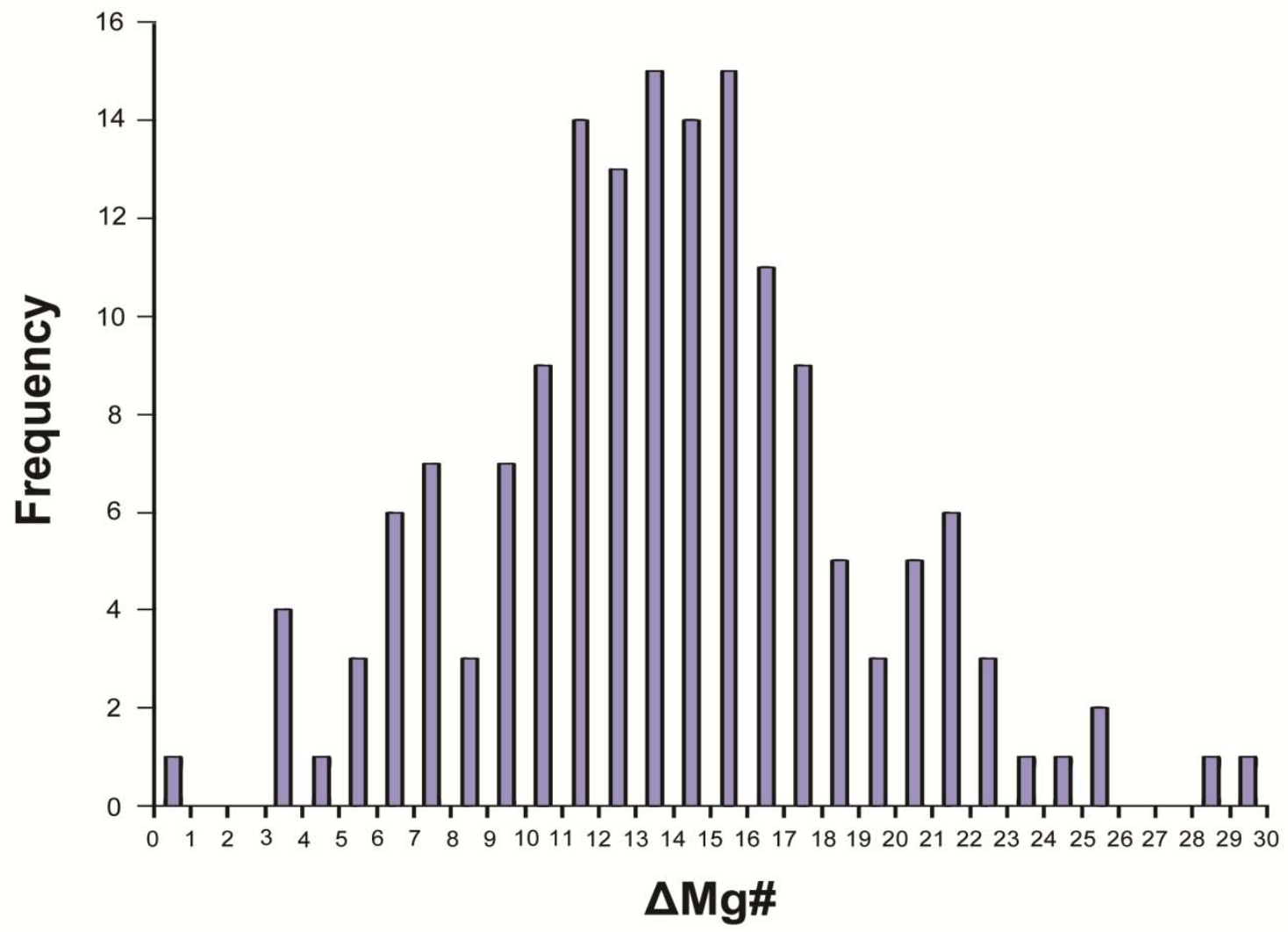

Figure 3.2: Histogram showing the range in $\mathrm{Mg} \#$ present in individual clinopyroxenes. Each analysis contributing toward the frequency is a single clinopyroxene crystal. $\Delta \mathrm{Mg} \#$ is obtained by subtracting the lowest Mg\# of any of the zones within the crystal from the highest Mg\# found within that crystal. 

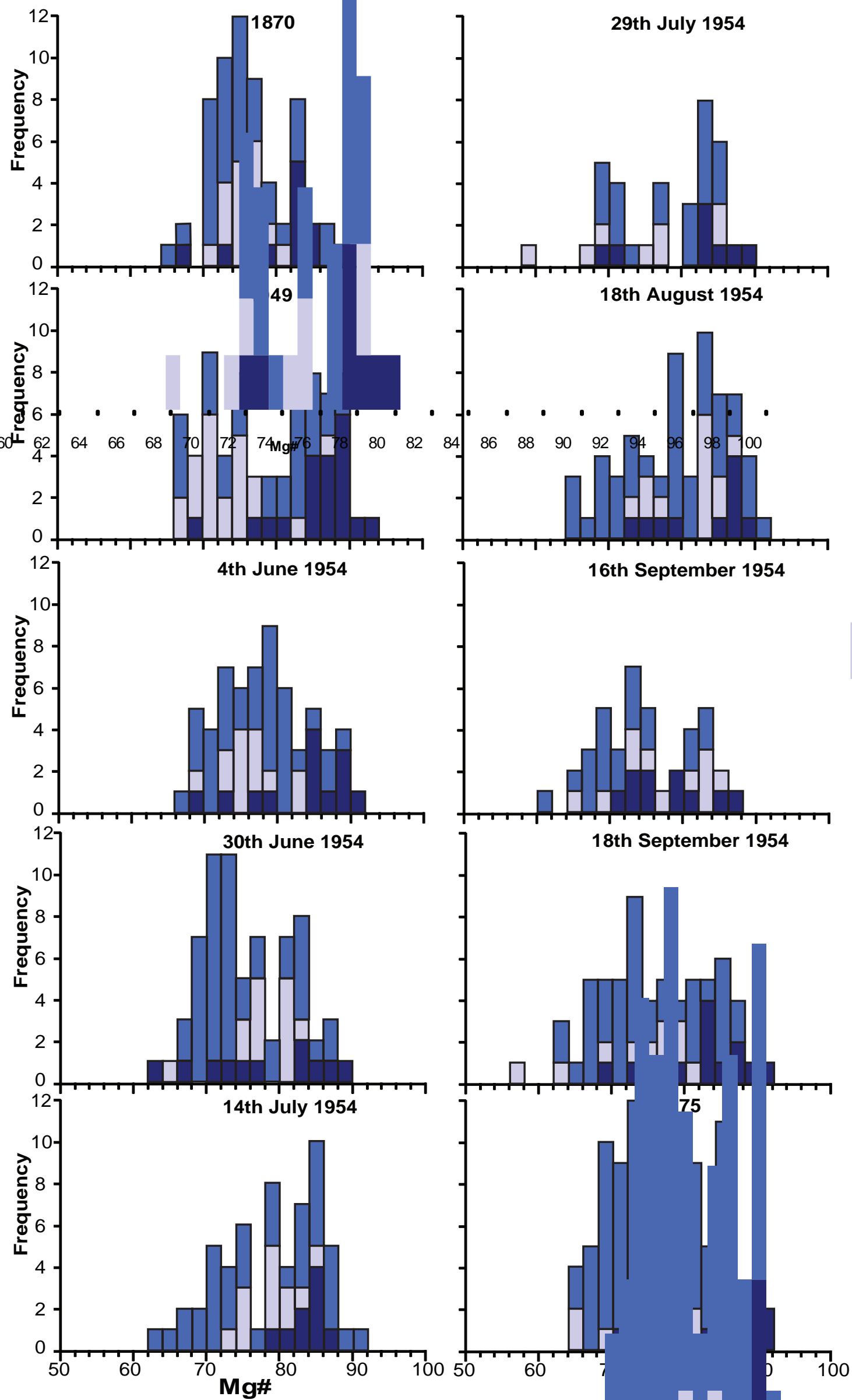

Figure 3.3: Histograms ordered chronologically by date of eruption showing the Mg\# of analyses of clinopyroxene crystal cores (dark blue), rims (light blue), and other parts of the crystals (medium blue). 


\subsubsection{Orthopyroxene}

Orthopyroxene is abundant throughout the historical lava flows, as discussed in Chapter 2. It shows strong zoning patterns similar to the clinopyroxene crystal population, although without the distinct Mg-rich cores; whilst some crystals possess Mg-rich cores, much of the crystal population has rims or other zoning with equal or greater $\mathrm{Mg \#}$ than the core (Figure 3.4). Overall, Mg\# is lower than for clinopyroxene, ranging from Mg\# 51-85. $\mathrm{SiO}_{2}, \mathrm{Al}_{2} \mathrm{O}_{3}$ and $\mathrm{Cr}_{2} \mathrm{O}_{3}$ decrease with decreasing $\mathrm{Mg \#}$ whilst $\mathrm{TiO}_{2}$ and $\mathrm{CaO}$ are negatively correlated with Mg\#. There are small differences between the different samples, for example the 1975 orthopyroxene analyses have lower $\mathrm{Cr}_{2} \mathrm{O}_{3}$ and higher $\mathrm{CaO}$ than the other samples, whereas the 1949 sample has lower $\mathrm{CaO}$ than both the 1975 and 1870 orthopyroxenes. The three orthopyroxene analyses with particularly low Mg\# (45-55) do not follow many of the trends exhibited by the rest of the data and are a population of Ferich low-Ca cores. Despite being relatively rare, these cores occur in samples erupted almost 85 yr apart: SB32 (1870) and SB45 (18th September 1954). 

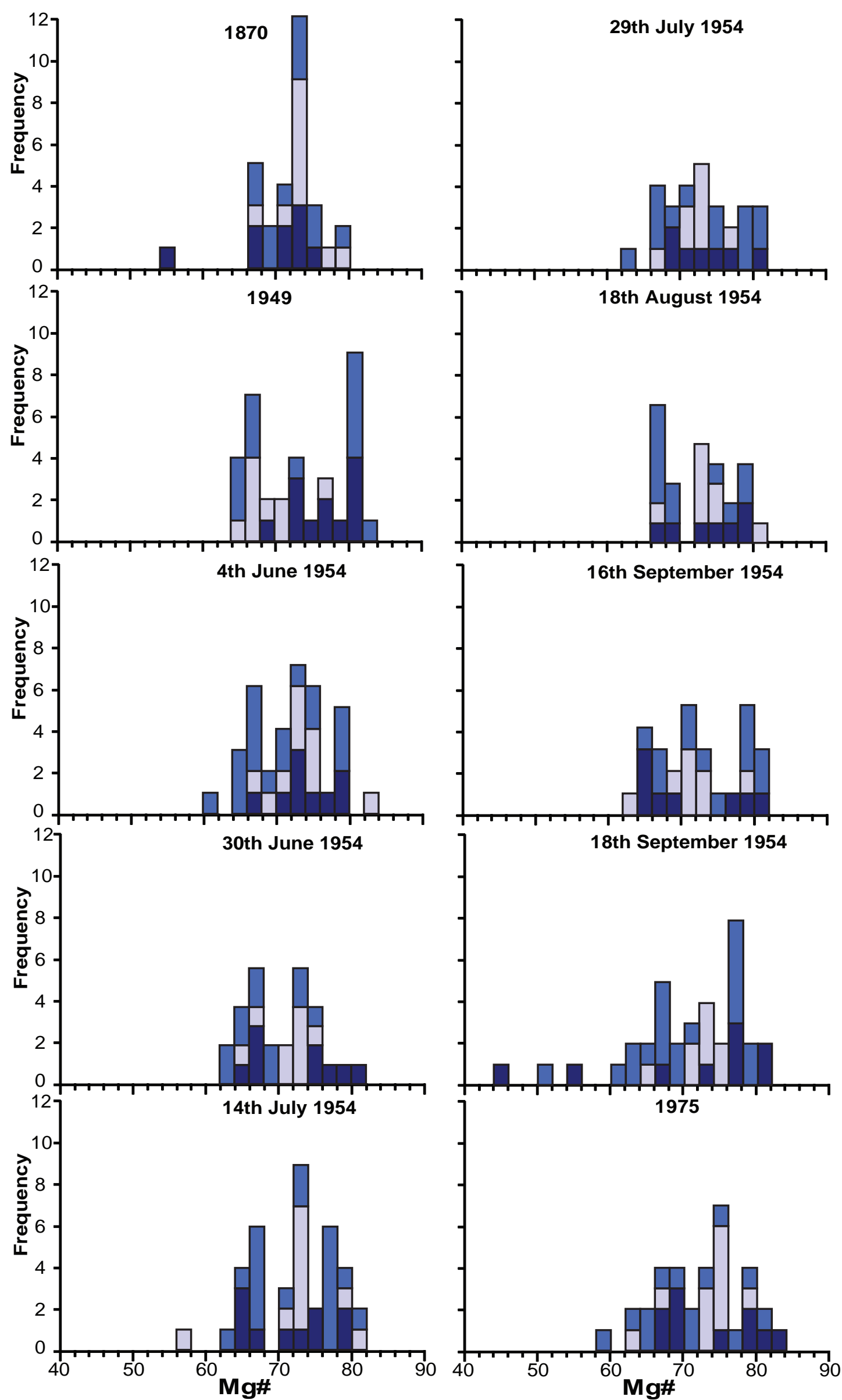

Figure 3.4: Histograms ordered chronologically by date of eruption showing the Mg\# of analyses of orthopyroxene crystal cores (dark blue), rims (light blue), and other parts of the crystals (medium blue). 


\subsubsection{Plagioclase}

Plagioclase crystals extend from anorthite through to labradorite compositions ( $\left.\mathrm{An}_{92}{ }^{-51}\right)$, although the distribution is bimodal (Figure 3.5). The crystal population consists largely of Ca-rich cores and more sodic rims, but more complex zoning patterns and sodic cores are also common. There appear to be small differences in the anorthite content of plagioclase rims between lava flows (Figure 3.6), but more analyses would be required to confirm this. Core composition does not appear to change throughout the historical lava flows.

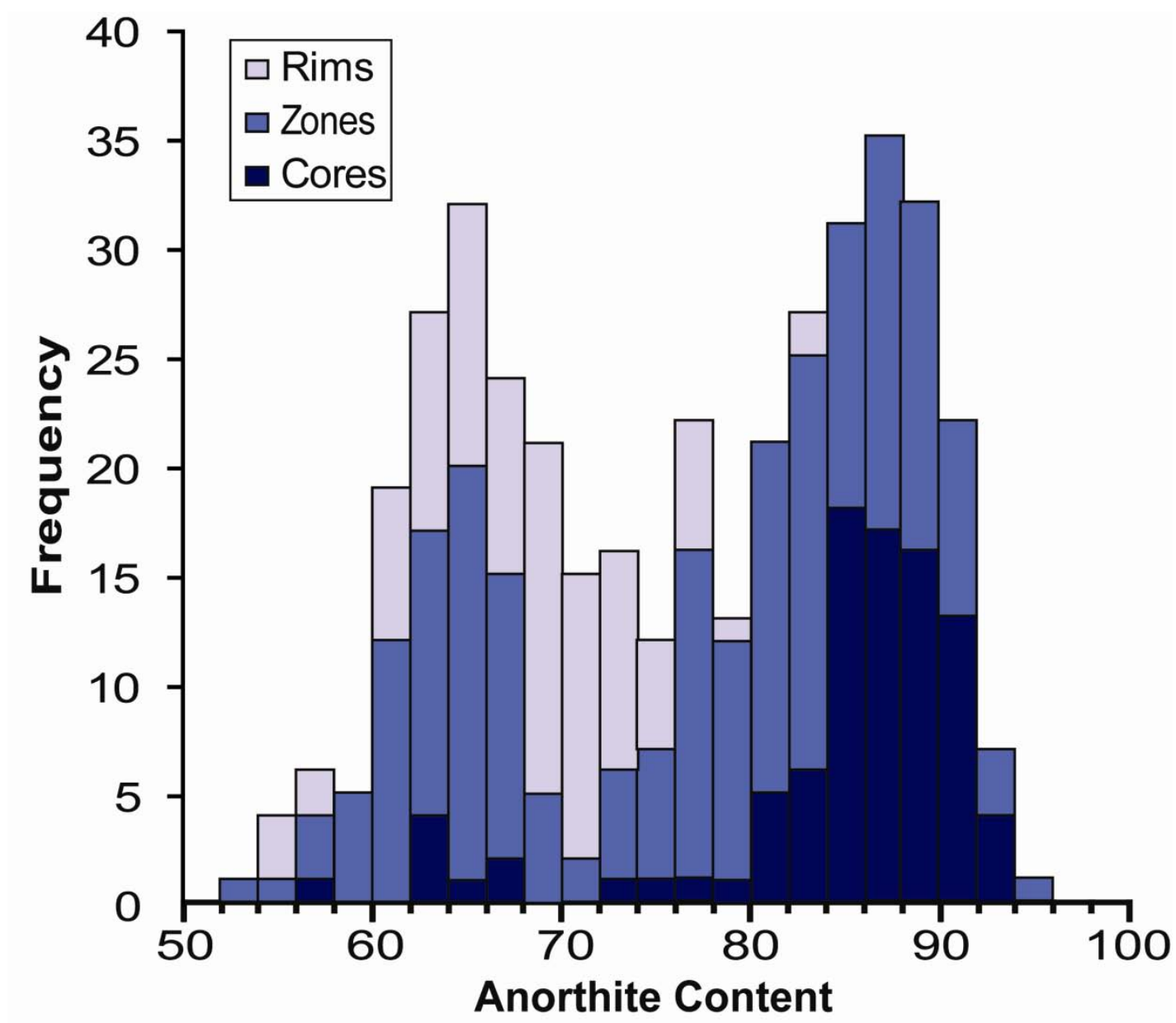

Figure 3.5: Histogram of anorthite content of plagioclase analyses for all samples, showing the anorthite content of cores, rims, and other zoning that lies between the core and rim. 


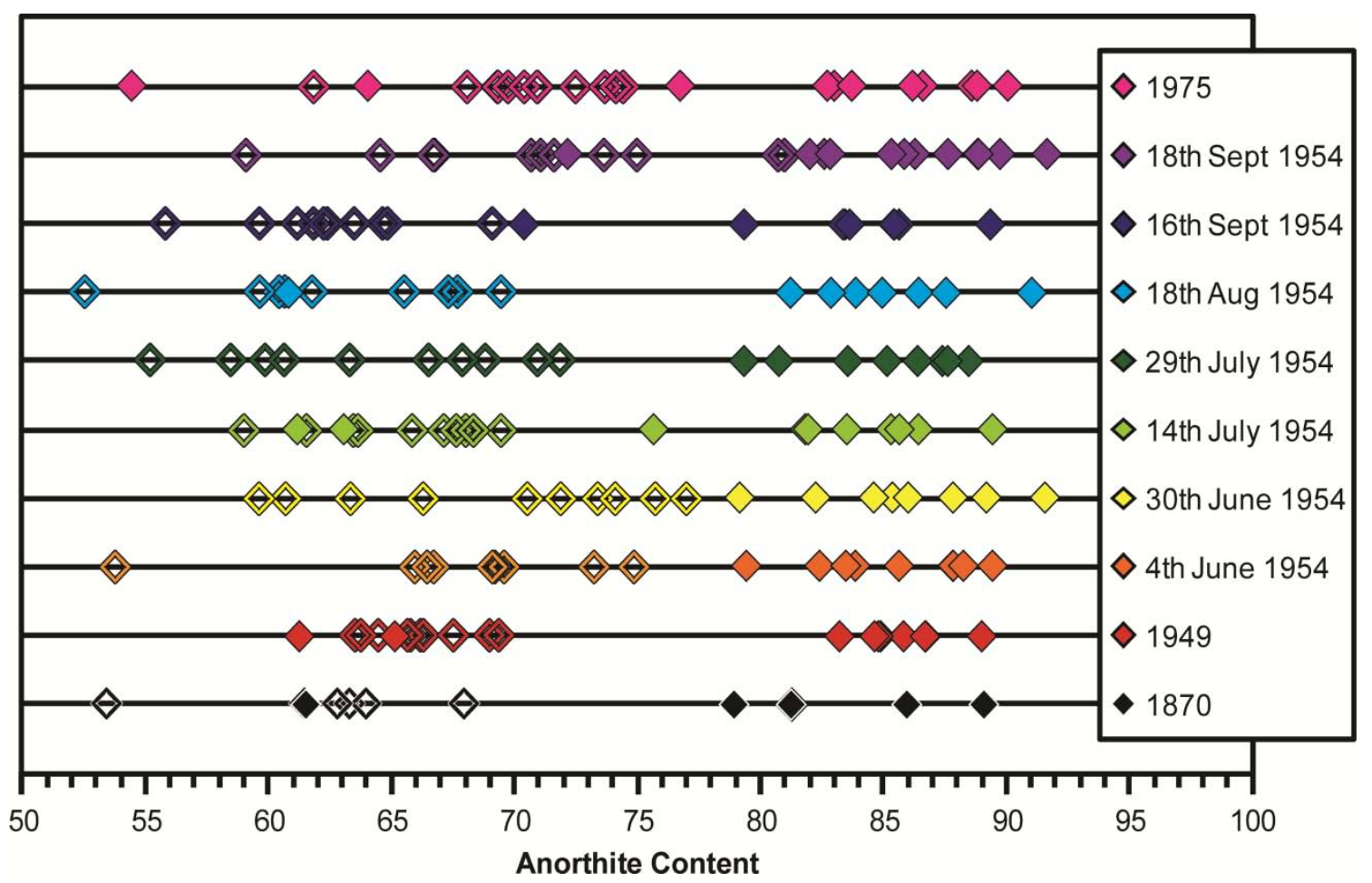

Figure 3.6: Graph showing the anorthite content of cores (filled diamonds) and rims (hollow diamonds) of plagioclase crystals, ordered by lava flow.

\subsubsection{Olivine}

Olivine crystals occur in all flows but are rare, as discussed in Chapter 2. Occasionally rims with more Fe-rich chemistry than the cores are observed, however, similar zoning is also frequently present around melt inclusions, indicating that the more Fe-rich chemistry is the result of diffusive re-equilibration with the surrounding melt or reaction rim rather than a primary crystallisation feature. Because of this, only results from analyses of olivine cores are presented here. However, the high degree of alteration of the olivine crystals means that in some cases these apparent cores may not be the true crystal core, as the more silicic melt may have infiltrated cracks in the crystals meaning they have not experienced equal resorption from all sides. In addition it is possible that some crystals which have resided in the melt for longer periods of time have experienced complete reequilibration with a new melt. A plot of olivine Mg\# by lava flow (Fig 3.7) shows a bimodal distribution for the majority of the lava flows, although this is possibly influenced by the small sample size. 


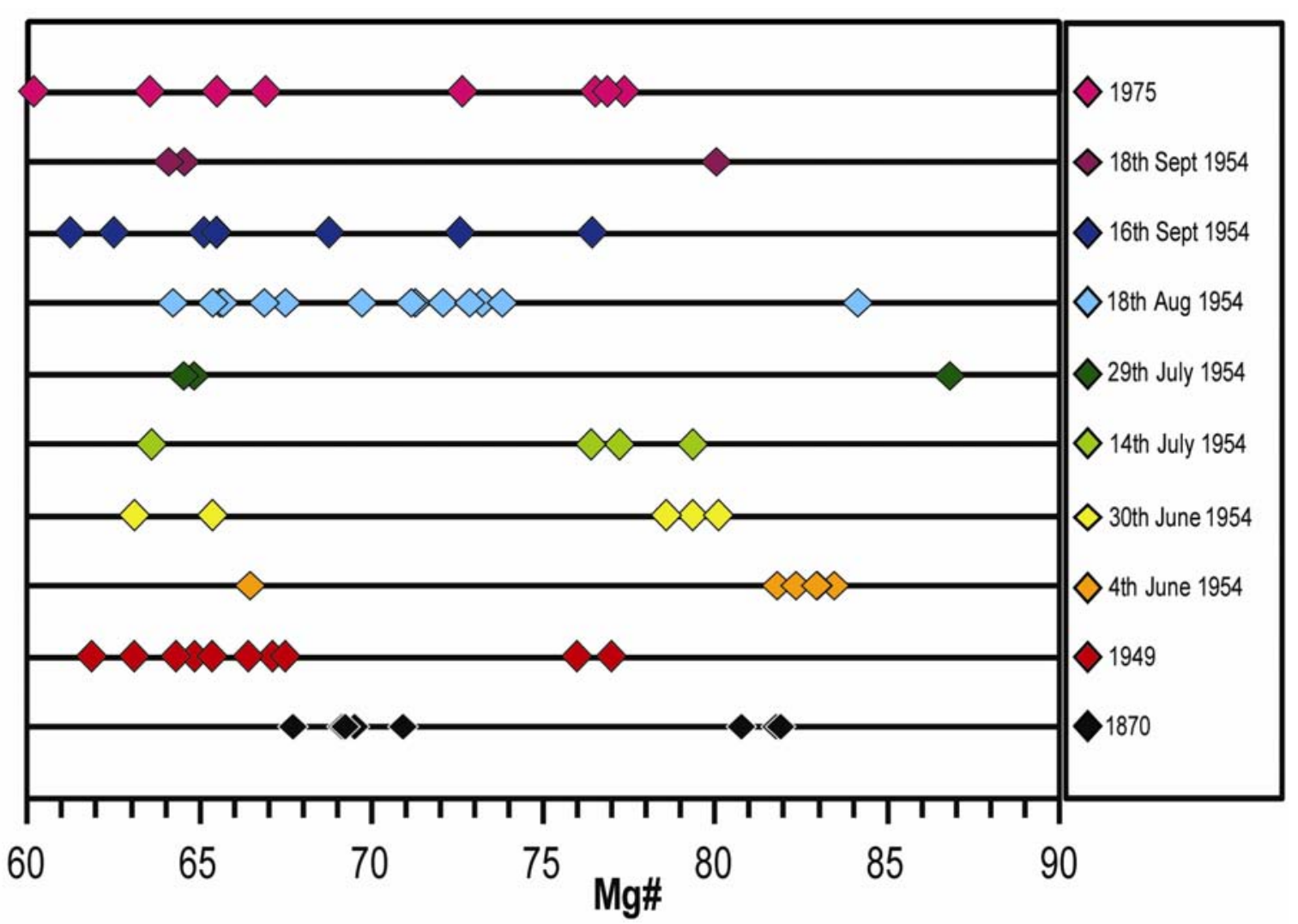

Figure 3.7: Graph showing the Mg\# of olivine cores ordered chronologically by the date of eruption of the lava flows, with the oldest sample analysed (1870) at the bottom.

\subsubsection{Fe-Ti oxides}

The groundmass of several samples $\left(1870,1949,4^{\text {th }}\right.$ June $1954,18^{\text {th }}$ August 1954) contains abundant Fe-Ti oxides, but their small size precludes geochemical analysis. Fe-Ti oxides large enough to analyse occur both as separate equant crystals $\sim 20-100 \mu \mathrm{m}$ across, and as inclusions in the other crystal phases (olivine, clinopyroxene, orthopyroxene, plagioclase). However, those which occur as inclusions appear to almost always have crystallised from melt inclusions. Vermicular Fe-Ti oxides also form part of the reaction rim surrounding many olivine crystals, and in some cases these oxides and orthopyroxene are all that remain of a former olivine. Fe-Ti oxides which occur as separate crystals are all titanomagnetite with the exception of rare low Ti magnetite and hercynite. Only two of the 23 Fe-Ti oxides analysed that occur as separate crystals are low Ti magnetite, with both occurring in the 18th August 1954 lava flow. Only two crystals of hercynite were found as well, one in the 18th August 1954 lava flow and one in the 29th July 1954 lava flow; in both cases the crystals were surrounded by an orthopyroxene reaction rim. However, a number of oxides with the same appearance were observed in thin section. Fe- 
Ti oxide inclusions in crystal phases are also titanomagnetite, although titanomagnetite crystals which occur as inclusions generally have lower $\mathrm{TiO}_{2}$, and higher $\mathrm{MgO}$ and $\mathrm{Al}_{2} \mathrm{O}_{3}$ than those which occur as separate crystals (Figure 3.8). In addition, Cr-spinel and rare ilmenite occur as inclusions in the olivine crystals, and anhedral blebs of iron sulphide crystals occur as inclusions throughout all crystal phases. The Cr-spinel analysed is of two types, one which has only 22-23 wt\% Cr, and one which has 44-45 wt\% Cr, with no apparent relationship to the $\mathrm{Mg \#}$ of the olivine with which they are associated.
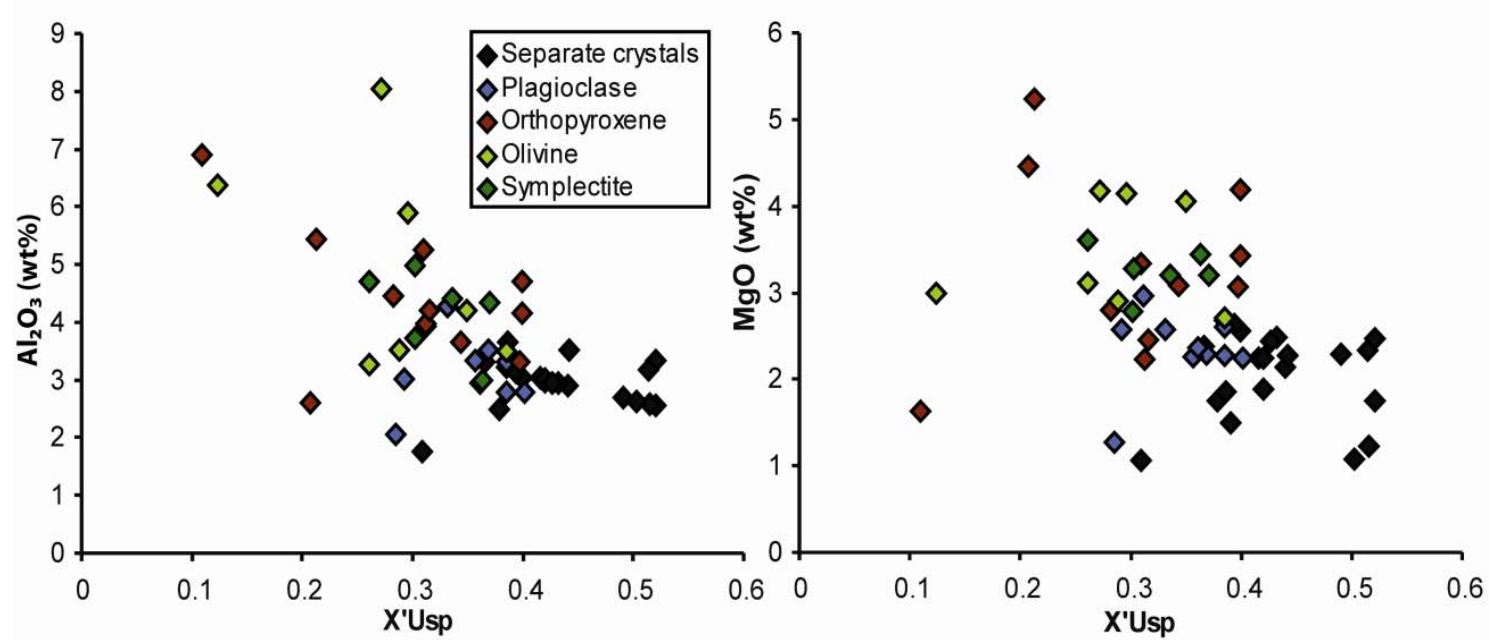

Figure 3.8: Graphs showing weight percent $\mathrm{MgO}$ and $\mathrm{Al}_{2} \mathrm{O}_{3}$ versus $\mathrm{X}$ 'Usp of the Fe-Ti oxide crystal population, where X'Usp is the apparent mole fraction of ulvöspinel relative to magnetite using the calculation of Stormer (1983). Lower X'Usp values therefore indicate lower Ti contents. Oxide analyses have been divided into groups depending on whether the oxide occurs as a separate crystal, an inclusion in another crystal phase, or as part of a reaction rim around an olivine crystal (symplectite).

\subsubsection{Glass}

The results from major element analyses of groundmass glass and clinopyroxene melt inclusions are presented below. The number of analyses and number of flows that groundmass glass data are presented for is limited by the microlite-rich nature of the groundmass and the necessity of using a defocused $(10 \mu \mathrm{m})$ electron microprobe beam to avoid volatile loss. Plotting the groundmass glass data on a total alkalis silica plot (Figure 3.9a) shows it to be considerably more silicic than whole rock data (Hobden, 1997), lying in the dacitic to rhyolitic fields despite the rocks being classed as basaltic andesites. Clinopyroxene melt inclusion data (Figure 3.9b) are in agreement with this, varying from 60-72 wt\% $\mathrm{SiO}_{2}$ with no apparent relationship to the Mg\# of the zones in which they 
occur. Groundmass glass data show decreasing $\mathrm{TiO}_{2}, \mathrm{FeO}, \mathrm{MgO}$ and $\mathrm{CaO}$ with increasing $\mathrm{SiO}_{2}$, and increasing $\mathrm{Na}_{2} \mathrm{O}$ and $\mathrm{Al}_{2} \mathrm{O}_{3}$ with the exception of the 1870 and 1949 lava flows (Figure 3.10). This may be due to the crystallisation of titanomagnetite in the groundmass of the 1870 and 1949 lava flows, which is considerably more abundant than in the later flows as can be seen in Figure 2.3. Melt inclusion data differs from groundmass glass data primarily in the lack of a trend in $\mathrm{TiO}_{2}$, which for the clinopyroxene melt inclusions is below 1.5 wt\% (Figure 3.11). Groundmass glass data with $\mathrm{TiO}_{2}$ below 1.5\% (the 1870 and 1949 lava flows) similarly shows no variation with increasing $\mathrm{SiO}_{2}$. A particularly notable feature of the melt inclusion data is that the 1975 clinopyroxenes appear to contain two distinct populations of melt inclusions: one population that follows the same trends as the other lava flows and another population that lies on quite separate trends. The separate population of 1975 melt inclusions contains double the Fe concentrations of the other inclusions and shows no correlation between $\mathrm{SiO}_{2}$ and $\mathrm{Al}_{2} \mathrm{O}_{3}$, whereas the other melt inclusions exhibit a negative correlation. 

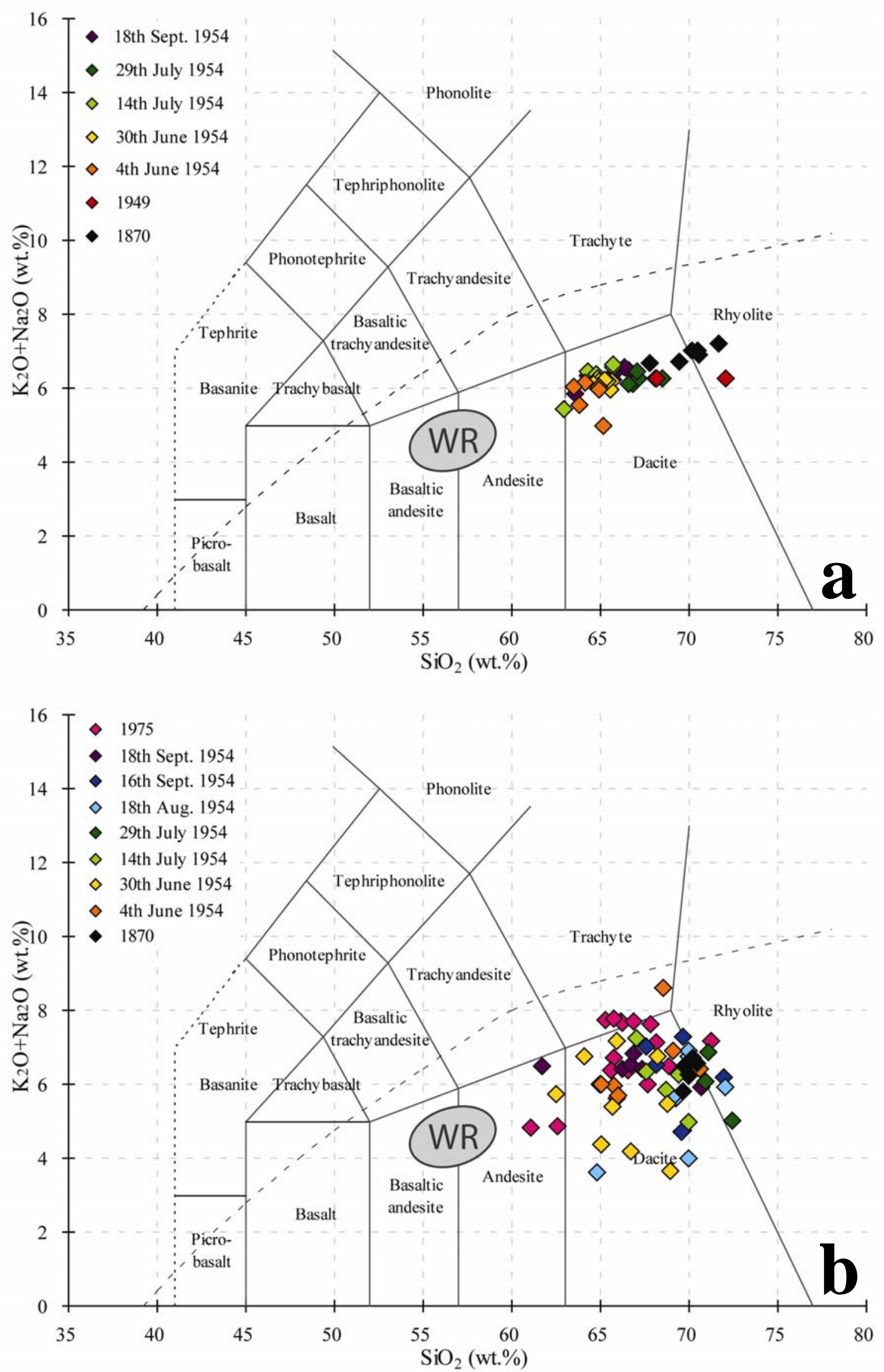

Figure 3.9: Total alkalis silica diagrams of EPMA analyses of (a) groundmass glass and (b) clinopyroxene melt inclusions. Whole-rock data for the historical Ngauruhoe lava flows is marked by the grey area labelled 'WR', and uses data from Hobden (1997). 

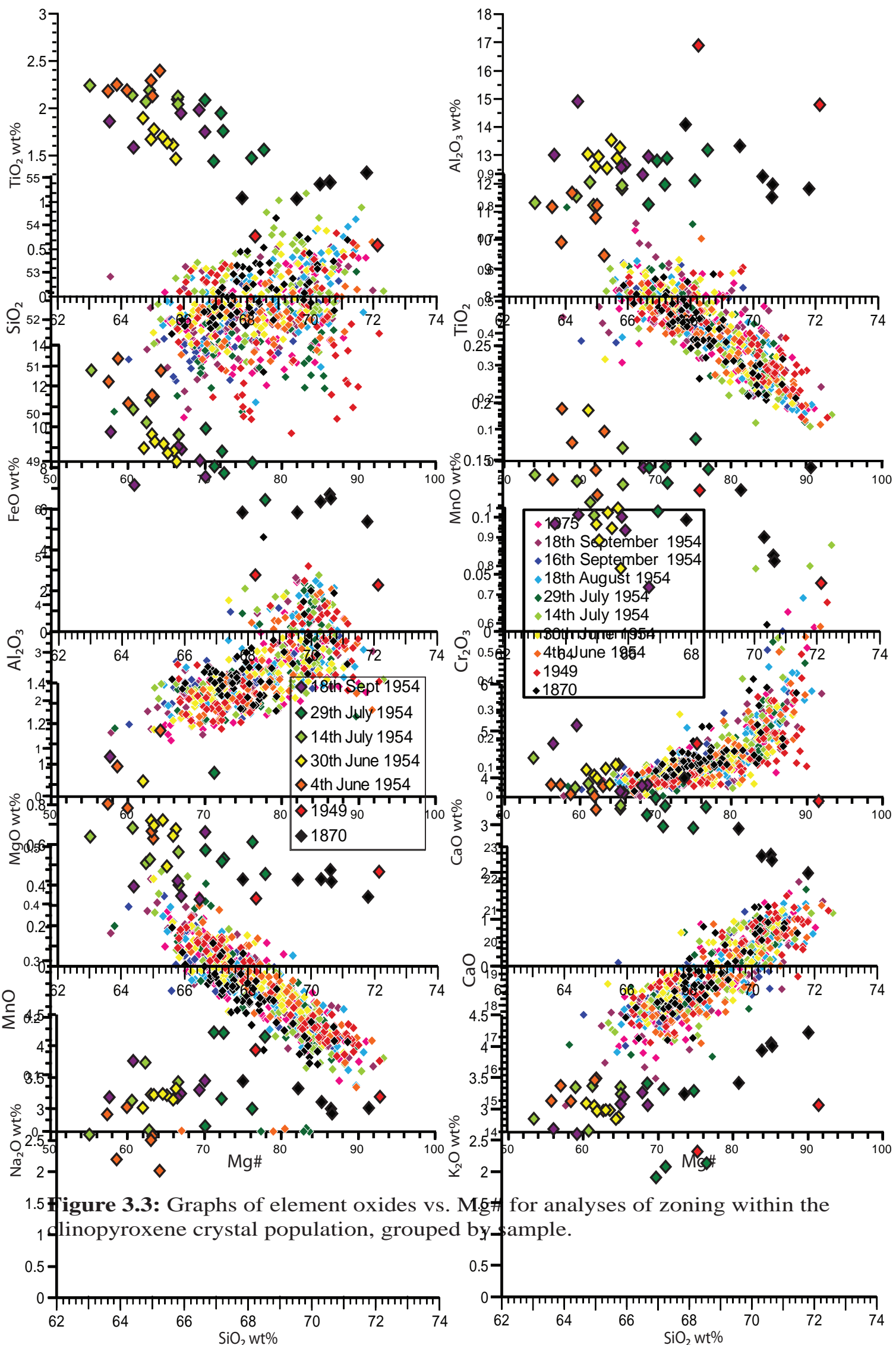

Figure 3.10: Graphs of element oxides vs. $\mathrm{SiO}_{2} \mathrm{wt} \%$ for groundmass glass, grouped by lava flow. 

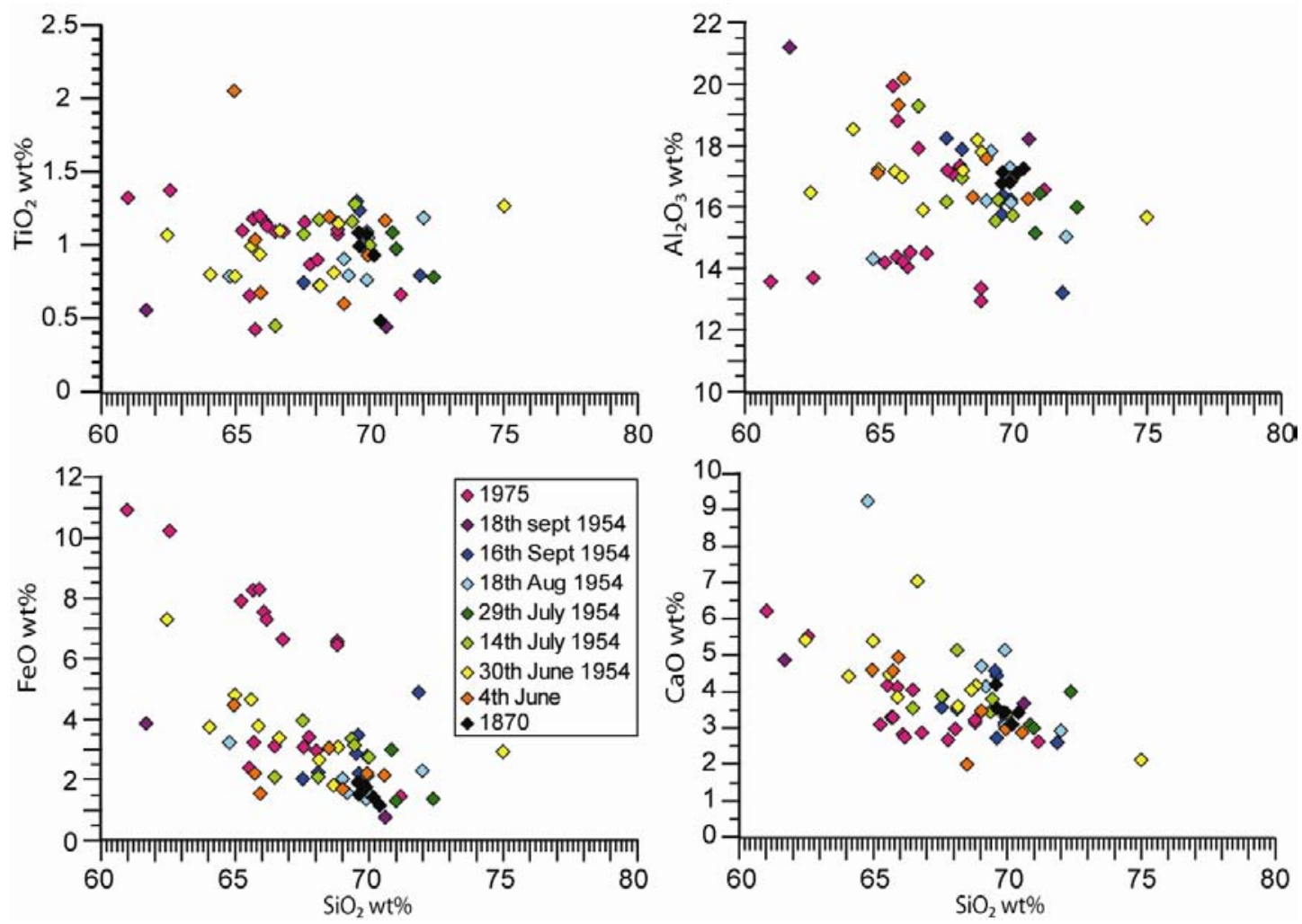

Figure 3.11: Graphs of element oxides versus $\mathrm{SiO}_{2}$ for clinopyroxene melt inclusions, grouped by lava flow. 


\subsection{Mineral minor and trace element chemistry}

\subsubsection{Clinopyroxene}

Clinopyroxene minor and trace element data are presented as ratios or individual elements against Ce and Mg\# in Figure 3.12, and as rare earth element (REE) plots in Figure 3.13. $\mathrm{Cr}$ and $\mathrm{Sr} / \mathrm{Nd}$ both show a curved decrease with decreasing Mg\#. Eu/Eu* (calculated using chondrite-normalised back-calculated melt values) and $\mathrm{Ni}$ also decrease with decreasing Mg\#. However, the trends do not appear to be curved, and for $\mathrm{Ni}$ the relationship with $\mathrm{Mg \#}$ is much more scattered. Highly incompatible elements such as Ta and Nb were not measurable. Moderately incompatible elements, such as V, Sc, Zr, Ti and Zn display a strong linear negative correlation with $\mathrm{Mg \# .} \mathrm{Zr/Y} \mathrm{increases}$ with increasing Ce up until about 5 ppm Ce, after which the ratio becomes flat. All samples show an increasingly negative Eu anomaly with increasing REE, but the 1870 sample has a smaller negative Eu anomaly than later lava flows. The 1975 lava flow has a slightly lower La/Ce than some of the other lava flows, in particular the 1949 flow. Generally, differences between the lava flows are minor, however.

The chondrite-normalised REE plots are all light rare earth element (LREE) depleted, with flat heavy rare earth element (HREE) profiles, as is expected for a clinopyroxene profile. REE plots have been presented as direct clinopyroxene analyses normalised to chondrite rather than back-calculated to melt compositions normalised to chondrite, as a suitable set of partition coefficients could not be found. However, when back-calculated, the general features that would be expected from a continental arc setting are present: moderate enrichment of LREE, and a flat HREE profile indicating a shallow (spinel lherzolite) rather than a deep mantle source. 

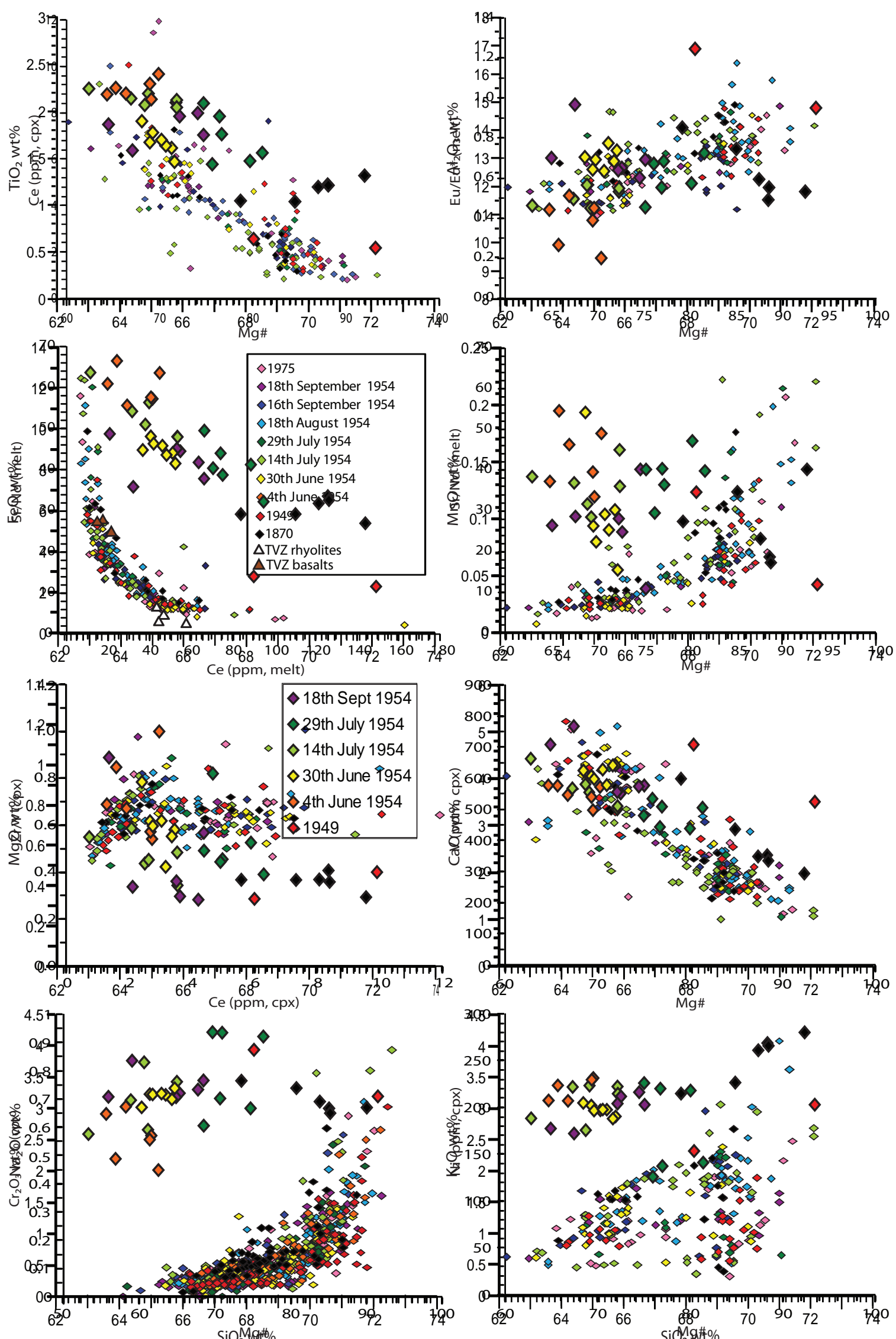

Figure 3.12: Clinopyroxene minor and trace element data, grouped by sample. The top four graphs use back-calculated melt compositions, calculated using partition coefficients from Zajacz and Halter (2007). The lower four graphs use the raw clinopyroxene concentrations. Some whole rock TVZ data have been included on the Sr/Nd vs Ce graph for comparison. Basalt data are the Kakuki, K-trig and Red crater basalts from Gamble et al. (1993), and rhyolite data are the Kawakawa, Potaka and Rotoehu Tephras from Allan (2008). Eu/Eu* $=\mathrm{Eu}_{\mathrm{N}}{ }^{2} /\left(\mathrm{Sm}_{\mathrm{N}} \cdot \mathrm{Gd}_{\mathrm{N}}\right)^{0.5}$, where $\mathrm{Eu}_{\mathrm{N}}, \mathrm{Sm}_{\mathrm{N}}$ and $\mathrm{Gd}_{\mathrm{N}}$ are the measured abundances back-calculated to melt compositions (Zajacz and Halter, 2007) and chondrite normalised using Sun and McDonough (1989). 

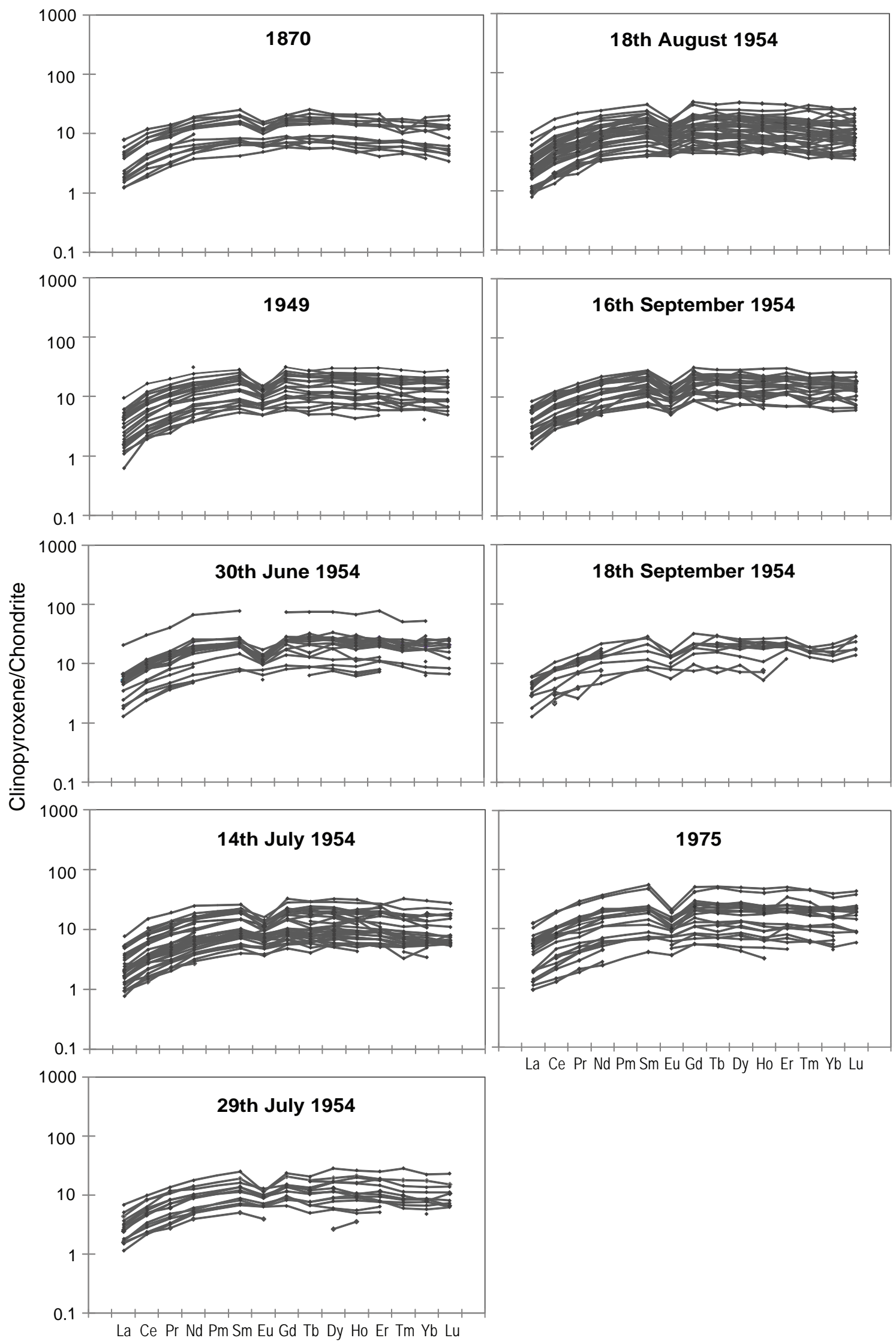

La Ce Pr Nd Pm Sm Eu Gd Tb Dy Ho Er Tm Yb Lu

Figure 3.13: Chondrite-normalised (Sun \& McDonough, 1989) rare earth element plots of clinopyroxene analyses, ordered by date of eruption. 


\subsubsection{Plagioclase}

Selected trace elements measured in plagioclase are presented in Figure 3.14. Rb/Sr, Y, $\mathrm{Ba}, \mathrm{Ce}$ and $\mathrm{Pb}$ all increase with decreasing An, with concentrations varying by at least a factor of three. The range in $\mathrm{Rb} / \mathrm{Sr}$ is considerably larger, varying by a factor of $>7$ (from 0.00025 to 0.0019 ). As with the clinopyroxene trace element data, any differences between the samples are minor: all lava flows plot within similar fields and exhibit the same trends. A Ba versus Sr plot using back-calculated melt values obtained using partition coefficients from Blundy and Wood (1991) appears to show two gaps in the Sr concentration, as indicated by the black arrows. The lower Sr side of the graph consists of rims and sodic cores. Tracing the paths of individual crystals where more than two zones (core/rim) were measured shows no clear trend: crystals may either increase or decrease in Sr or Ba before the final low-Sr rim. The 1949 lava flow has the lowest Sr concentrations.
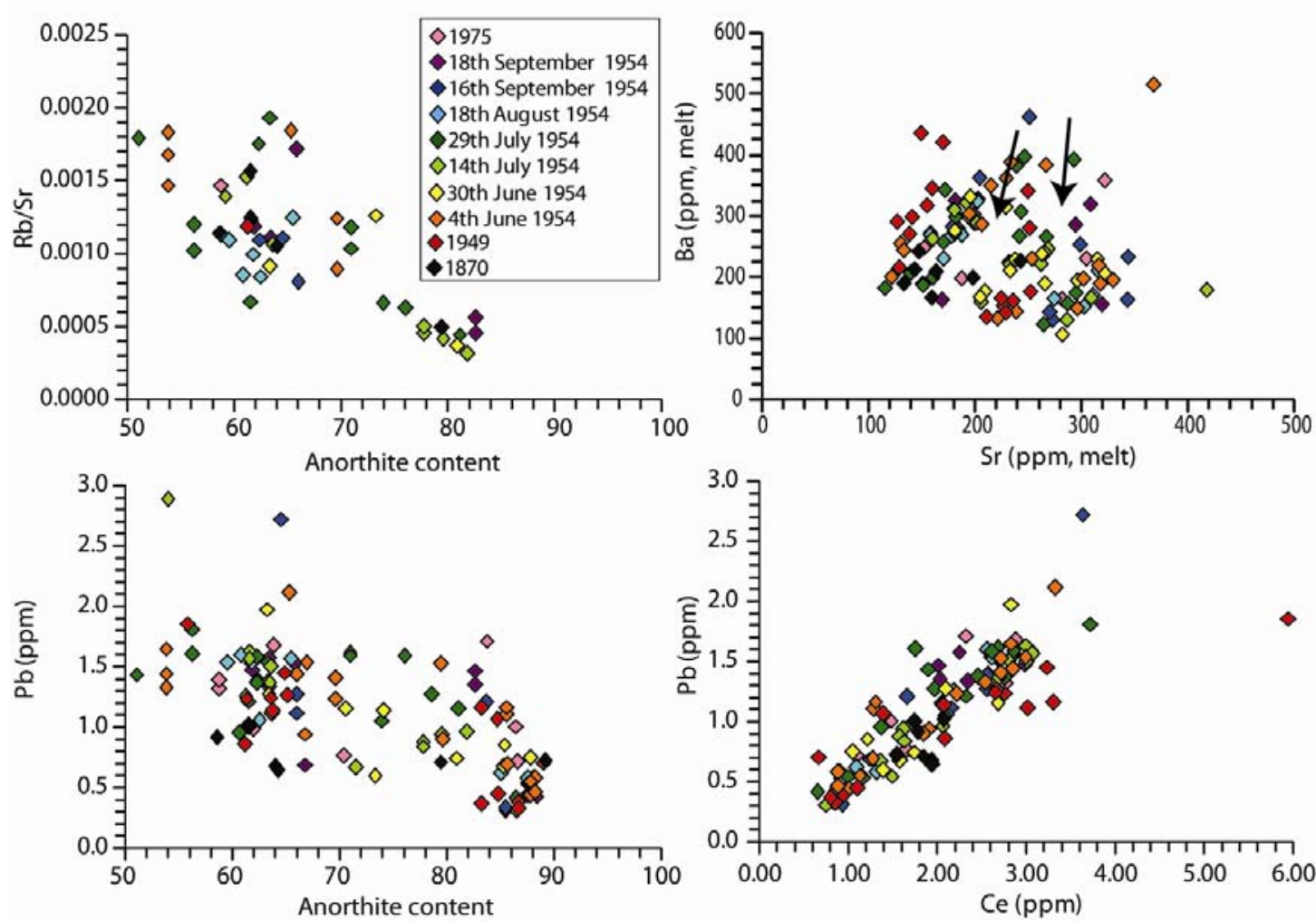

Figure 3.14: Graphs of selected trace elements measured in plagioclase crystals. All graphs use the concentrations of the elements measured in plagioclase with the exception of the Ba versus Sr plot, which uses back-calculated melt concentrations obtained using the equations of Blundy and Wood (1991). 


\subsection{Diffusion Modelling Results}

Probability density functions for timescales calculated on the outermost rims of the clinopyroxene population are given in Figure 3.15. These indicate the relative probability that the true age of the rim occurs at a given point. A broader curve suggests the true age is less well constrained from the given data than a pronounced peak - i.e. wider range of ages for individual rims will result in a broader overall curve. Two peaks of the main curve would indicate there may be two separate crystal populations. Temperature errors also affect the broadness of the curve. For these graphs, a temperature error of $\pm 56^{\circ} \mathrm{C}$ has been selected: this is the standard error of the estimate (SEE) for the thermometer given by Putirka (2008), but is larger than the 2 sd of the temperatures calculated for any of the lava flows, as shown in Appendix 4. Longer individual timescales always have a broader curve than shorter timescales as the temperature error produces a greater timescale error for long timescales than it does for short ones. All lava flows suggest that the outermost rim formed only weeks to months prior to eruption, with the peak in relative probability occurring at about $0.1 \mathrm{yr}$ for most samples. The $30^{\text {th }}$ June 1954 and the 1975 lava flows peak at slightly higher ages of 0.16-0.18 yr, but this may be due to a larger number of rims being modelled for these two samples resulting in a larger spread of data, rather than any true timescale difference.

A number of mafic clinopyroxene crystal cores were also modelled, and the results from this are presented in Figure 3.16. Crystal cores were more difficult to model as many of them have been affected by resorption or contain abundant melt inclusions, making it difficult to find a straight diffusion boundary suitable for modelling. The boundaries are also more diffuse and thus much wider, necessitating a larger area of the crystal to be completely free of any scratches or inclusions that affect the greyscale of images of the crystals. Due to the fewer number of ages obtained as a result of these issues, all samples have been grouped together to form the relative probability curves in Figure 3.16. There were no clear differences in the timescales obtained for cores between the different samples to suggest a problem with grouping them together, and as similar textures are observed throughout the historical eruptions, pooling the data together may 
aid observation of any recurring features. The large range in ages obtained (0.05-152 yr) made it necessary to plot the lower and higher age ranges on separate graphs. Half of the timescales obtained have therefore been plotted on the top graph and the remaining half (that giving longer timescales) have been plotted on the bottom graph of Figure 3.16. The middle graph encompasses the middle range of the data, i.e. it contains the longer timescales from the top graph and the shorter timescales from the bottom graph, in order to allow for some comparison between the shorter and longer timescales with the one main probability density function curve. Probability density function curves were calculated using a temperature error of $\pm 56^{\circ} \mathrm{C}$ as was used for the calculation of the rim density functions, and it is worth noting that timescales were also calculated using the same temperatures as the rims for each sample. The first and middle graphs clearly suggest that the shortest core timescales calculated (0.05-1.4 yr) are a distinct population from the longer timescales. Interpretation of the longer timescales is more difficult. There may be two further populations, one at $\sim 4-8 \mathrm{yr}$ and one at $\sim 20-30 \mathrm{yr}$, but a much smaller temperature error $\left( \pm 20^{\circ} \mathrm{C}\right)$ is required to produce two separate peaks in the overall probability density function curve at these timescales. As temperatures calculated using two-pyroxene thermometry of crystal rims have been applied to inner zoning, there is no justification for any reduction in temperature error, and the overall probability density function of the bottom graph merges the crystals into a single population with a peak probability at a timescale of $\sim 12$ yr (bottom graph of Figure 3.16). There is no evidence to suggest that the longest timescales calculated for mafic cores of 50-152 yr are real: only four timescales occur within this range, and the temperature effect at such timescales so large that reducing the temperature by only $30^{\circ} \mathrm{C}$ would drop the $152 \mathrm{yr}$ timescale to only $70 \mathrm{yr}$. They may instead be the result of poorly sectioned crystals that have not been bisected directly through the crystal core, making the boundaries appear more diffuse than they actually are and resulting in artificially longer timescales.

Only 11 crystal cores that were more felsic than adjacent zoning were modelled. These have not been presented in graph form due to the small number of boundaries modelled and the large range in timescales obtained. This range is broadly similar to the mafic 
crystal cores: five boundaries gave ages of $<1 \mathrm{yr}$, four had ages in the range 3-10 yr, one returned an age of $24 \mathrm{yr}$ and one returned a much longer age of $172 \mathrm{yr}$. 

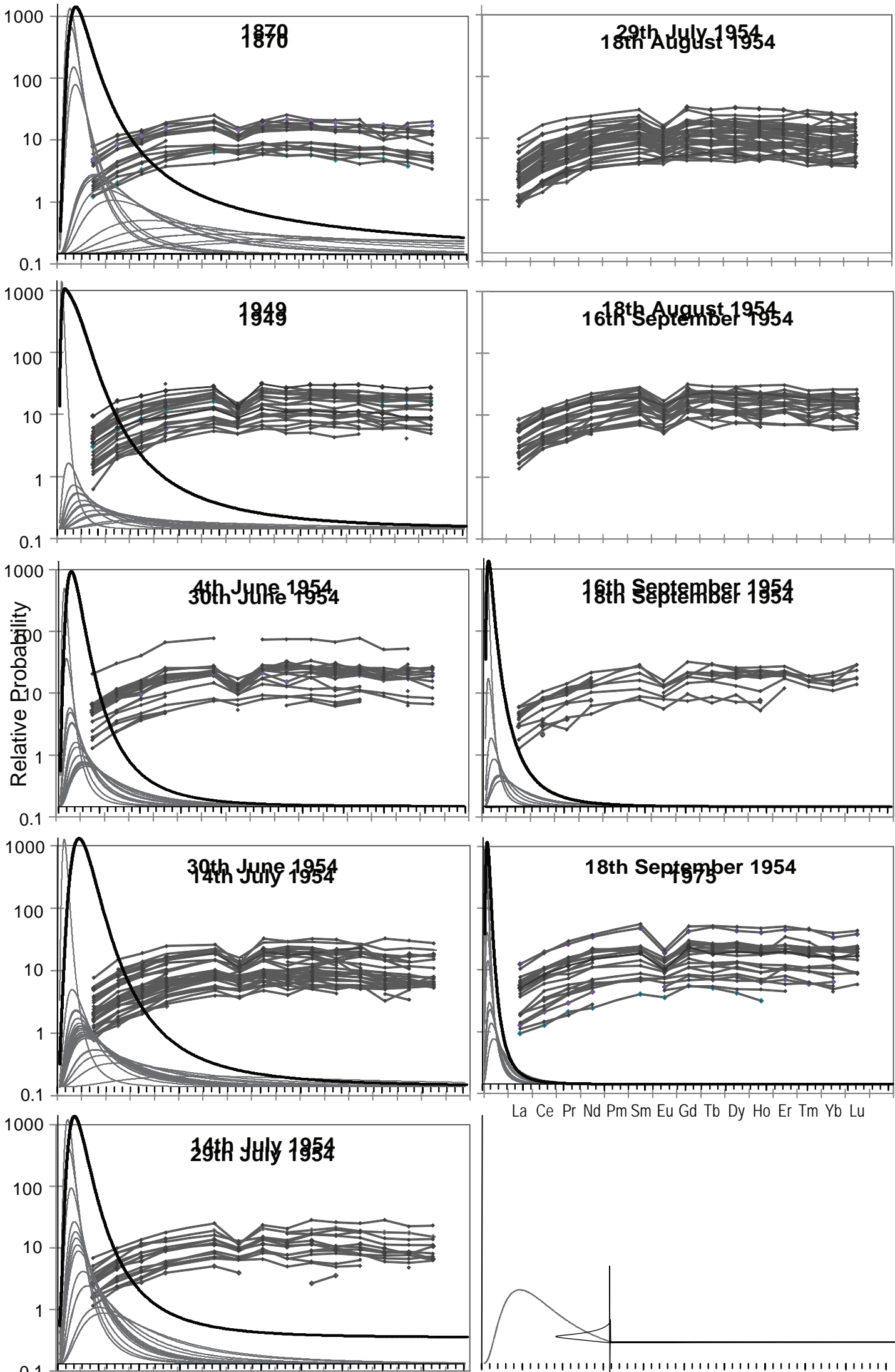

18th August 1954

18th September 1954

Figure 3.15: Probability density function curves for the ages obtained for the outermost rims of the clinopyroxene crystal population, with samples ordered chronologically by date of eruption. The thick black curve on each graph represents the probability density function for all the rim ages of the sample, while the thin grey curves are the probability density functions for individual crystals. The temperature errors used in the calculation of the curves are $\pm 56^{\circ} \mathrm{C}$. 

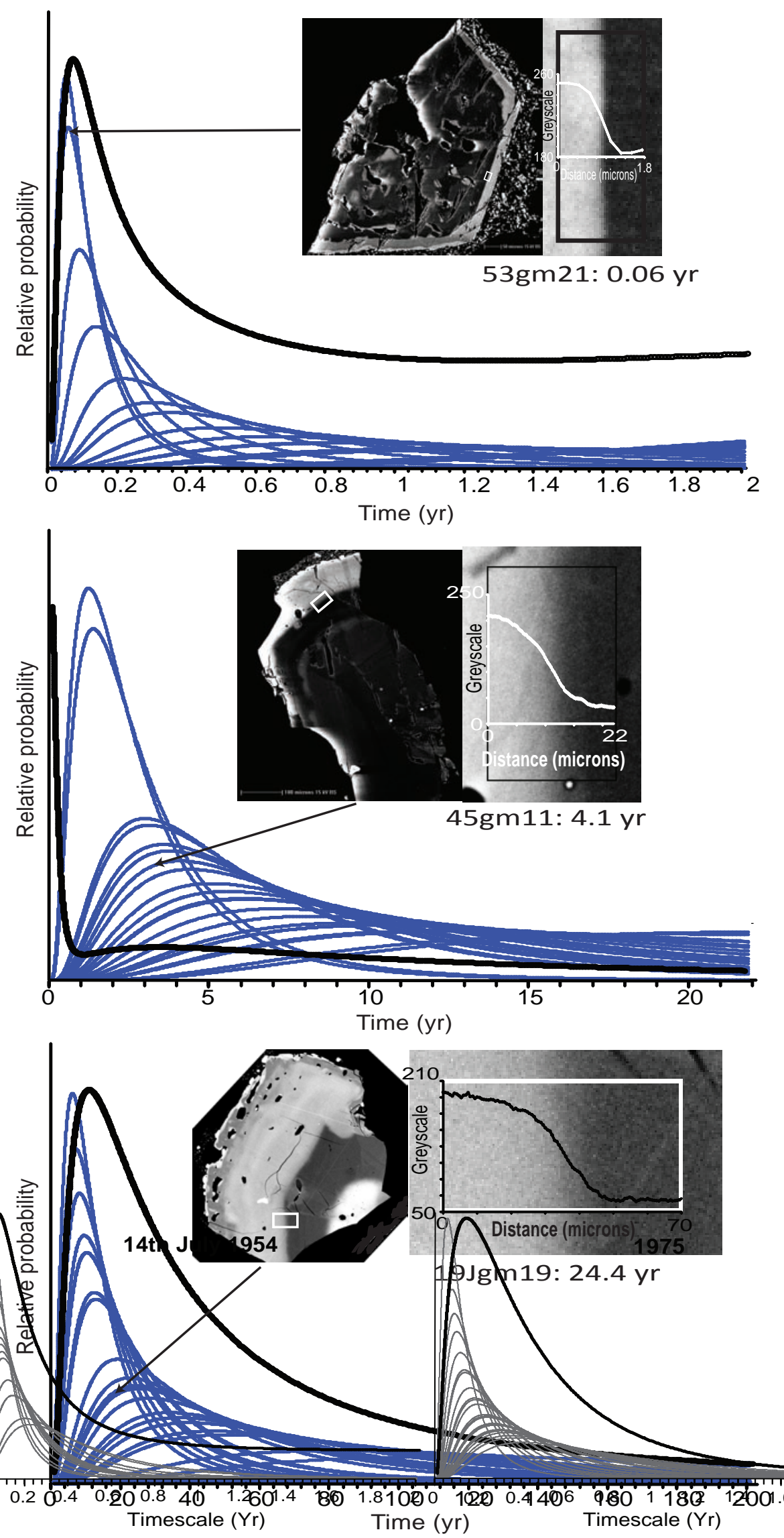

Figure 3.16: Probability density function curves for the ages obtained for mafic clinopyroxene cores. All lava flows have been grouped together as there were no obvious differences in ages calculated between the different flows, and the small number of cores able to be modelled for some samples necessitated the grouping of samples for comparison. Shorter timescales have been plotted on the top graph and longer timescales on the bottom graph, as the variation was too large to fit on one graph. The middle graph encompasses the middle range of data, to allow for easier comparison the shorter and longer timescales. 


\section{CHAPTER FOUR: \\ DISCUSSION}

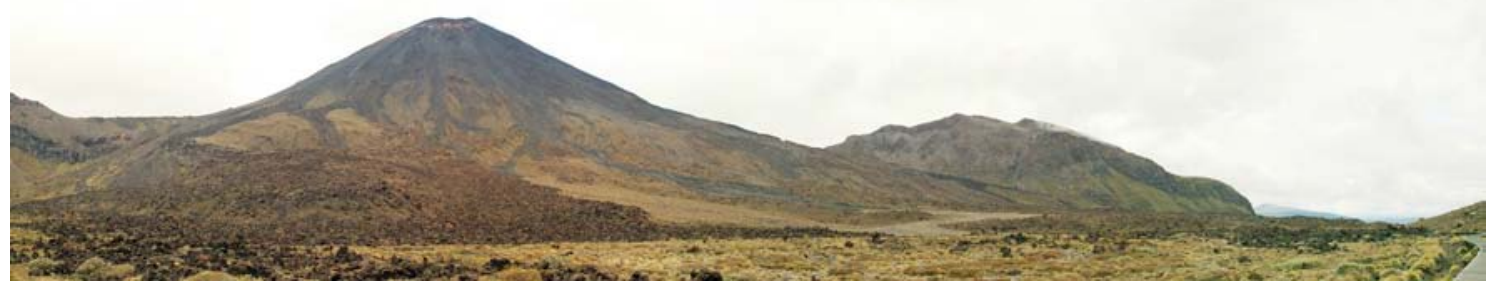

Plate 4: Panoramic view of Ngauruhoe from the Mangatepopo valley, the historically erupted lava flows (dark grey-black) clearly observable. Photograph by Marc-Alban Millet. 


\subsection{Nature of the melt}

Analyses of groundmass glass all plot in the dacite-rhyolite fields on a total alkalis silica plot, despite the fact that whole-rock analyses classify the lavas as basaltic andesites. The high silica glass contents are at odds with the evidence in the crystal population for mafic magma intrusion occurring shortly prior to eruption, such as the presence of Mgrich olivines in the 1975 lava flow that show no evidence of disequilibrium as well as the occurrence of thin Mg-rich rims on much of the clinopyroxene crystal population that give timescales from diffusion modelling of only weeks to months before eruption. However, the groundmass of the historical Ngauruhoe lava flows is particularly microlite-rich (Figure 2.3), and it is possible that crystallisation of these microlites during cooling after eruption may have shifted the composition of the groundmass glass to significantly more silicic compositions than the erupted melt. In order to assess how large an effect microlite crystallisation has had on the groundmass glass chemistry, mixing calculations were carried out to determine the expected whole-rock compositions that would occur assuming the glass chemistry is representative of the bulk groundmass composition. The abundance in weight percent of each major element in a crystal phase was averaged for all zoning in all crystals analysed of that phase in the sample. In this way, average compositions for each phase in each sample were obtained. These average compositions were then multiplied by the modal proportion of the phase in the lava flow, and added together to estimate the whole-rock composition, using the groundmass glass chemistry as the chemistry for groundmass. Whole-rock analyses used were taken from Hobden (1997). The modal proportions used for modelling of the 1870 lava flow were also taken from Hobden (1997), and were obtained by a pointcount that used a total of 1000 points on a thin section prepared from a sample of the eastern lobe of the 1870 lava flow (sample TG001). As no modal abundance data were available for the other lava flows, visual estimates made from the thin sections prepared for this thesis were used instead. Results of the modelling are presented in Table 4.1. 
Table 4.1: Mixing modelling calculations to determine the whole-rock compositions that would be expected if groundmass glass chemistry were representative of bulk groundmass chemistry. The lava flow is given in the top-left corner of each section. Whole-rock analyses were taken from Hobden (1997), so the sample numbers from that study have been given in brackets above the data, e.g. TG001. The 'Glass' column contains an averaged composition of groundmass glass analysed for the sample, but the modal proportion given beneath it is the proportion of groundmass. 'MIX' shows the calculation of the expected whole-rock chemistry. The 'Difference' column is the measured wholerock chemistry subtracted from the expected whole-rock chemistry.

\begin{tabular}{|c|c|c|c|c|c|c|c|c|}
\hline 1870 & $\begin{array}{c}\text { Whole-rock } \\
\text { (TG001) }\end{array}$ & Glass & Plag & Opx & Cpx & Olivine & MIX & Difference \\
\hline $\mathrm{SiO}_{2}$ & 55.44 & 70.12 & 49.62 & 52.62 & 52.12 & 37.79 & 62.29 & 6.85 \\
\hline $\mathrm{TiO}_{2}$ & 0.77 & 1.17 & 0.05 & 0.49 & 0.39 & & 0.82 & 0.05 \\
\hline $\mathrm{Al}_{2} \mathrm{O}_{3}$ & 16.48 & 12.50 & 31.46 & 2.13 & 2.67 & & 14.54 & -1.94 \\
\hline $\mathrm{FeO}$ & 9.12 & 6.10 & 0.79 & 17.90 & 9.52 & 24.56 & 6.34 & -2.78 \\
\hline $\mathrm{MnO}$ & 0.16 & 0.10 & 0.00 & 0.40 & 0.23 & 0.37 & 0.11 & -0.05 \\
\hline $\mathrm{MgO}$ & 5.52 & 0.42 & 0.11 & 24.07 & 15.98 & 37.12 & 3.60 & -1.92 \\
\hline $\mathrm{CaO}$ & 8.60 & 2.66 & 14.99 & 2.33 & 18.84 & 0.16 & 5.89 & -2.71 \\
\hline $\mathrm{Na}_{2} \mathrm{O}$ & 2.83 & 3.13 & 2.77 & 0.03 & 0.25 & & 2.55 & -0.28 \\
\hline $\mathrm{K}_{2} \mathrm{O}$ & 1.12 & 3.81 & 0.23 & & & & 2.45 & 1.33 \\
\hline Total & 100.04 & 100.00 & 100.00 & 100.00 & 100.00 & 100.00 & 98.60 & \\
\hline Modal prop. & & 0.63 & 0.20 & 0.10 & 0.05 & 0.00 & & \\
\hline 1949 & $\begin{array}{c}\text { Whole-rock } \\
\text { (TG019) }\end{array}$ & Glass & Plag & Opx & Cpx & Olivine & MIX & Difference \\
\hline $\mathrm{SiO}_{2}$ & 56.51 & 70.19 & 50.44 & 53.28 & 51.73 & & 63.09 & 6.58 \\
\hline $\mathrm{TiO}_{2}$ & 0.77 & 0.59 & 0.07 & 0.31 & 0.40 & & 0.44 & -0.33 \\
\hline $\mathrm{Al}_{2} \mathrm{O}_{3}$ & 16.97 & 15.83 & 30.85 & 1.92 & 2.69 & & 17.18 & 0.21 \\
\hline $\mathrm{FeO}$ & 8.42 & 2.52 & 0.87 & 17.15 & 9.47 & & 3.77 & -4.65 \\
\hline $\mathrm{MnO}$ & 0.14 & 0.08 & & 0.38 & 0.24 & & 0.10 & -0.04 \\
\hline $\mathrm{MgO}$ & 4.60 & 0.40 & 0.09 & 25.05 & 15.91 & & 3.34 & -1.26 \\
\hline $\mathrm{CaO}$ & 7.72 & 4.13 & 14.31 & 1.87 & 19.30 & & 7.39 & -0.33 \\
\hline $\mathrm{Na}_{2} \mathrm{O}$ & 2.88 & 3.56 & 3.08 & 0.04 & 0.25 & & 2.94 & 0.06 \\
\hline $\mathrm{K}_{2} \mathrm{O}$ & 1.25 & 2.69 & 0.28 & & & & 1.74 & 0.49 \\
\hline Total & 99.26 & 100.00 & 100.00 & 100.00 & 100.00 & & 100.00 & \\
\hline Modal prop. & & 0.63 & 0.23 & 0.08 & 0.08 & & & \\
\hline $\begin{array}{c}\text { 4th June } \\
1954 \\
\end{array}$ & $\begin{array}{c}\text { Whole-rock } \\
\text { (TG038) }\end{array}$ & Glass & Plag & Opx & Cpx & Olivine & MIX & Difference \\
\hline $\mathrm{SiO}_{2}$ & 55.94 & 64.48 & 49.17 & 52.96 & 51.95 & & 57.67 & 1.73 \\
\hline $\mathrm{TiO}_{2}$ & 0.76 & 2.24 & 0.04 & 0.45 & 0.37 & & 1.23 & 0.47 \\
\hline $\mathrm{Al}_{2} \mathrm{O}_{3}$ & 16.94 & 10.72 & 31.89 & 2.03 & 2.60 & & 13.89 & -3.05 \\
\hline $\mathrm{FeO}$ & 9.02 & 12.08 & 0.81 & 17.18 & 9.58 & & 9.78 & 0.76 \\
\hline $\mathrm{MnO}$ & 0.15 & 0.15 & & 0.37 & 0.24 & & 0.16 & 0.01 \\
\hline $\mathrm{MgO}$ & 5.38 & 0.84 & 0.09 & 24.71 & 16.27 & & 5.78 & 0.40 \\
\hline $\mathrm{CaO}$ & 8.33 & 3.70 & 15.21 & 2.26 & 18.72 & & 7.86 & -0.47 \\
\hline $\mathrm{Na}_{2} \mathrm{O}$ & 2.86 & 2.54 & 2.58 & 0.03 & 0.25 & & 1.94 & -0.92 \\
\hline $\mathrm{K}_{2} \mathrm{O}$ & 1.10 & 3.26 & 0.21 & & & & 1.68 & 0.58 \\
\hline Total & 100.48 & 100.00 & 100.00 & 100.00 & 100.00 & & 100.00 & \\
\hline Modal prop. & & 0.50 & 0.25 & 0.15 & 0.10 & & & \\
\hline
\end{tabular}




\begin{tabular}{|c|c|c|c|c|c|c|c|c|}
\hline $\begin{array}{c}\text { 30th June } \\
1954\end{array}$ & $\begin{array}{c}\text { Whole-rock } \\
\text { (TG023) }\end{array}$ & Glass & Plag & Opx & Cpx & Olivine & MIX & Difference \\
\hline $\mathrm{SiO}_{2}$ & 55.91 & 65.27 & 50.08 & 53.00 & 51.75 & & 60.73 & 4.82 \\
\hline $\mathrm{TiO}_{2}$ & 0.77 & 1.68 & 0.04 & 0.40 & 0.43 & & 1.20 & 0.43 \\
\hline $\mathrm{Al}_{2} \mathrm{O}_{3}$ & 17.04 & 12.98 & 31.30 & 1.57 & 2.41 & & 15.02 & -2.02 \\
\hline $\mathrm{FeO}$ & 8.89 & 8.98 & 0.75 & 18.61 & 10.48 & & 8.26 & -0.63 \\
\hline $\mathrm{MnO}$ & 0.14 & 0.10 & & 0.42 & 0.27 & & 0.12 & -0.02 \\
\hline $\mathrm{MgO}$ & 5.25 & 0.69 & 0.09 & 23.91 & 15.65 & & 3.18 & -2.07 \\
\hline $\mathrm{CaO}$ & 8.26 & 4.12 & 14.61 & 2.05 & 18.77 & & 6.68 & -1.58 \\
\hline $\mathrm{Na}_{2} \mathrm{O}$ & 2.85 & 3.20 & 2.91 & 0.03 & 0.25 & & 2.74 & -0.11 \\
\hline $\mathrm{K}_{2} \mathrm{O}$ & 1.10 & 2.97 & 0.22 & & & & 2.06 & 0.96 \\
\hline Total & 100.21 & 100.00 & 100.00 & 100.00 & 100.00 & & 100.00 & \\
\hline Modal prop. & & 0.68 & 0.19 & 0.08 & 0.05 & & & \\
\hline $\begin{array}{c}\text { 14th July } \\
1954\end{array}$ & $\begin{array}{c}\text { Whole-rock } \\
\text { (TG045) }\end{array}$ & Glass & Plag & Opx & Cpx & Olivine & MIX & Difference \\
\hline $\mathrm{SiO}_{2}$ & 55.77 & 64.78 & 49.66 & 52.95 & 52.20 & & 59.12 & 3.35 \\
\hline $\mathrm{TiO}_{2}$ & 0.70 & 2.13 & 0.04 & 0.43 & 0.35 & & 1.34 & 0.64 \\
\hline $\mathrm{Al}_{2} \mathrm{O}_{3}$ & 16.99 & 11.66 & 31.46 & 1.96 & 2.79 & & 15.79 & -1.20 \\
\hline $\mathrm{FeO}$ & 8.92 & 10.73 & 0.83 & 17.25 & 8.85 & & 8.40 & -0.52 \\
\hline $\mathrm{MnO}$ & 0.15 & 0.13 & & 0.40 & 0.23 & & 0.12 & -0.03 \\
\hline $\mathrm{MgO}$ & 5.34 & 0.56 & 0.10 & 24.59 & 16.31 & & 3.06 & -2.28 \\
\hline $\mathrm{CaO}$ & 8.39 & 3.77 & 14.91 & 2.39 & 19.02 & & 7.60 & -0.79 \\
\hline $\mathrm{Na}_{2} \mathrm{O}$ & 2.81 & 3.12 & 2.78 & 0.04 & 0.25 & & 2.64 & -0.17 \\
\hline $\mathrm{K}_{2} \mathrm{O}$ & 1.10 & 3.13 & 0.23 & & & & 1.94 & 0.84 \\
\hline Total & 100.17 & 100.00 & 100.00 & 100.00 & 100.00 & & 100.00 & \\
\hline Modal prop. & & 0.60 & 0.27 & 0.07 & 0.06 & & & \\
\hline $\begin{array}{c}\text { 29th July } \\
1954\end{array}$ & $\begin{array}{c}\text { Whole-rock } \\
\text { (TG042) }\end{array}$ & Glass & Plag & Opx & Cpx & Olivine & MIX & Difference \\
\hline $\mathrm{SiO}_{2}$ & 55.67 & 67.45 & 50.09 & 53.13 & 51.74 & & 62.09 & 6.42 \\
\hline $\mathrm{TiO}_{2}$ & 0.73 & 1.71 & 0.04 & 0.35 & 0.42 & & 1.21 & 0.48 \\
\hline $\mathrm{Al}_{2} \mathrm{O}_{3}$ & 16.79 & 12.38 & 31.14 & 1.71 & 2.81 & & 13.95 & -2.84 \\
\hline $\mathrm{FeO}$ & 8.73 & 8.20 & 0.88 & 17.35 & 9.57 & & 7.80 & -0.93 \\
\hline $\mathrm{MnO}$ & 0.15 & 0.14 & & 0.39 & 0.24 & & 0.14 & -0.01 \\
\hline $\mathrm{MgO}$ & 5.19 & 0.61 & 0.09 & 24.79 & 15.67 & & 3.66 & -1.53 \\
\hline $\mathrm{CaO}$ & 8.20 & 3.26 & 14.58 & 2.24 & 19.32 & & 6.39 & -1.81 \\
\hline $\mathrm{Na}_{2} \mathrm{O}$ & 2.88 & 3.58 & 2.93 & 0.03 & 0.24 & & 2.92 & 0.04 \\
\hline $\mathrm{K}_{2} \mathrm{O}$ & 1.12 & 2.68 & 0.26 & & & & 1.84 & 0.72 \\
\hline Total & 99.46 & 100.00 & 100.00 & 100.00 & 100.00 & & 100.00 & \\
\hline Modal prop. & & 0.67 & 0.17 & 0.08 & 0.08 & & & \\
\hline
\end{tabular}

The modelling in Table 4.1 indicates that microlite crystallisation has significantly affected the composition of the groundmass glass, as the whole-rock chemistry of the samples would be as much as $2-8 \%$ higher in $\mathrm{SiO}_{2}$ if groundmass glass were representative of the bulk groundmass composition. Further evidence for the strong control of groundmass glass chemistry by microlite crystallisation comes from the 
correlation of groundmass glass silica content with the abundance of microlites: the samples with the most silicic glass (the 1870 and 1949 lava flows) are those with the greatest microlite crystallisation (Figure 4.1). Estimating the original composition of the groundmass using the abundance and proportions of microlites results in the original groundmass being $\sim 53 \mathrm{wt} \% \mathrm{SiO}_{2}$ for the 1870 lava flow and $\sim 58 \mathrm{wt} \% \mathrm{SiO}_{2}$ for the $30^{\text {th }}$ June 1954 lava flow (Table 4.2). Groundmass analyses for a 1975 eruption sample from Hora (2003) obtained by rastering the EPMA beam over a small area (approximately 50 $\times 50 \mu \mathrm{m}$ ) give similar results ranging from 57-63 wt\% $\mathrm{SiO}_{2}$. This suggests that the erupted melt composition of the historical Ngauruhoe lava flows is in the basaltic andesite to high silica andesite range, a result that is in line with the observed evidence for mafic magma recharge shortly prior to eruption.

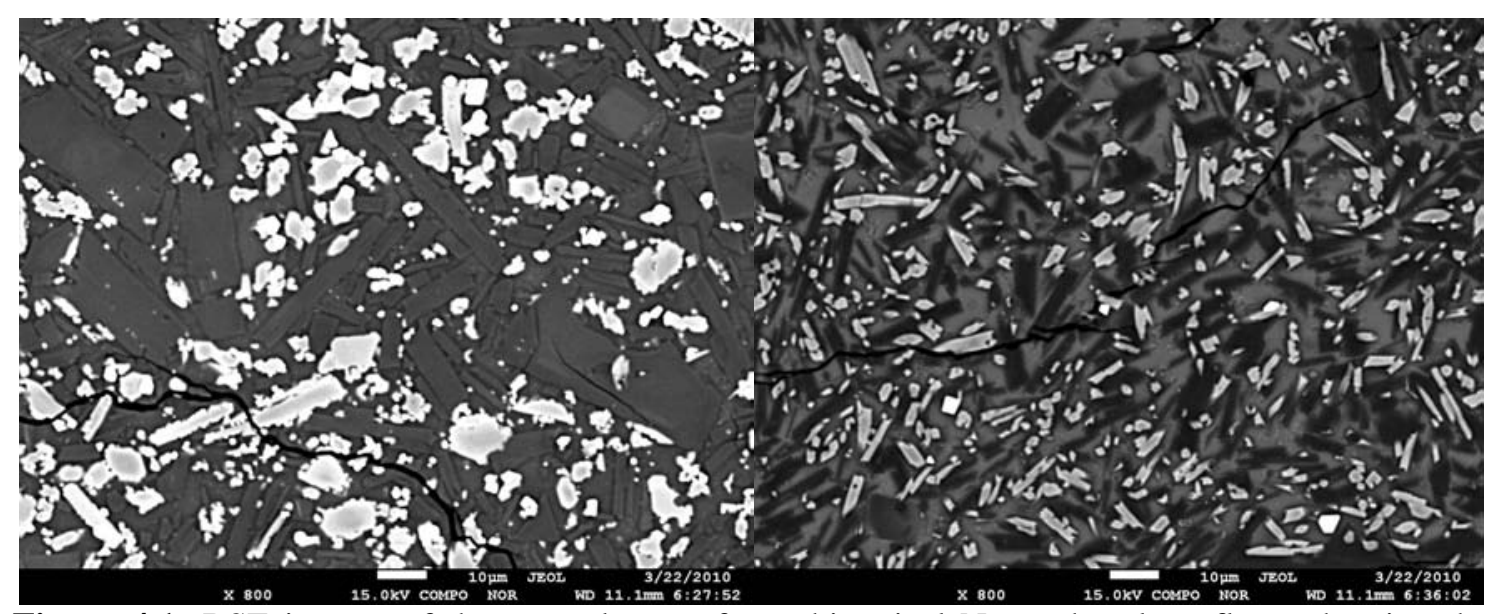

Figure 4.1: BSE images of the groundmass of two historical Ngauruhoe lava flows showing the extent of microlite crystallisation. Both images were taken at 800x magnification. The groundmass of the 1870 lava flow (left) is highly crystalline, consisting of predominantly plagioclase and lesser orthopyroxene, with minor titanomagnetite. Groundmass glass for the 1870 lava flow has $~ 70 \mathrm{wt} \%$ $\mathrm{SiO}_{2}$. The groundmass of the $30^{\text {th }}$ June 1954 lava flow (right), has only experienced $\sim 50 \%$ crystallisation of plagioclase and orthopyroxene microlites in subequal proportions, and thus the interstitial glass has a lower silica content than the 1870 lava flow ( $~ 65 \mathrm{wt} \% \mathrm{SiO}_{2}$ ). 
Table 4.2: Estimated composition of the erupted melt of the 1870 and $30^{\text {th }}$ June 1954 lava flows from mixing the components of the groundmass i.e., glass and microlites.

\begin{tabular}{|c|c|c|c|c|c|}
\hline 1870 & Glass & Plag & Opx & Magnetite & MIX \\
\hline $\mathrm{SiO}_{2}$ & 70.12 & 49.62 & 52.62 & 0.16 & 53.18 \\
\hline $\mathrm{TiO}_{2}$ & 1.17 & 0.05 & 0.49 & 13.26 & 0.60 \\
\hline $\mathrm{Al}_{2} \mathrm{O}_{3}$ & 12.50 & 31.46 & 2.13 & 2.66 & 22.69 \\
\hline $\mathrm{FeO}$ & 6.10 & 0.79 & 17.90 & 81.47 & 6.03 \\
\hline $\mathrm{MnO}$ & 0.10 & & 0.40 & 0.52 & 0.09 \\
\hline $\mathrm{MgO}$ & 0.42 & 0.11 & 24.07 & 1.87 & 3.80 \\
\hline $\mathrm{CaO}$ & 2.65 & 14.99 & 2.33 & 0.06 & 10.32 \\
\hline $\mathrm{Na}_{2} \mathrm{O}$ & 3.13 & 2.77 & 0.03 & & 2.37 \\
\hline $\mathrm{K}_{2} \mathrm{O}$ & 3.81 & 0.23 & & & 0.91 \\
\hline Total & 100.00 & 100.00 & 100.00 & 100.00 & 100.00 \\
\hline Modal prop & 0.20 & 0.63 & 0.15 & 0.02 & \\
\hline 30th June & Glass & Plag & Opx & Magnetite & MIX \\
\hline $\mathrm{SiO}_{2}$ & 65.27 & 49.62 & 52.62 & & 58.20 \\
\hline $\mathrm{TiO}_{2}$ & 1.68 & 0.05 & 0.49 & & 0.97 \\
\hline $\mathrm{Al}_{2} \mathrm{O}_{3}$ & 12.98 & 31.46 & 2.13 & & 14.89 \\
\hline $\mathrm{FeO}$ & 8.98 & 0.79 & 17.90 & & 9.16 \\
\hline $\mathrm{MnO}$ & 0.10 & & 0.40 & & 0.15 \\
\hline $\mathrm{MgO}$ & 0.69 & 0.11 & 24.07 & & 6.39 \\
\hline $\mathrm{CaO}$ & 4.12 & 14.99 & 2.33 & & 6.39 \\
\hline $\mathrm{Na}_{2} \mathrm{O}$ & 3.20 & 2.77 & 0.03 & & 2.30 \\
\hline $\mathrm{K}_{2} \mathrm{O}$ & 2.97 & 0.23 & & & 1.54 \\
\hline Total & 100.00 & 100.00 & 100.00 & & 100.00 \\
\hline Modal prop & 0.50 & 0.25 & 0.25 & & \\
\hline
\end{tabular}

Despite evidence for the historical Ngauruhoe lava flows having erupted glass/melt compositions that are basaltic to high silica andesite in composition, the clinopyroxene melt inclusions that were analysed have silica contents that place them almost exclusively in the dacitic to rhyolitic fields (Figure 3.9), which cannot be easily explained by microlite crystallisation. The main cluster of melt inclusion data lies in the range 65-73 wt\% $\mathrm{SiO}_{2}$. This range is slightly higher than that of the groundmass glass analyses which, with the exception of the 1870 lava flow, are generally in the range 63$69 \mathrm{wt} \% \mathrm{SiO}_{2}$. No basaltic and just four andesitic melt inclusions were identified, despite mineral chemistries that clearly indicate the involvement of basaltic magmas in the system. Similar observations of intermediate rocks containing only dacitic-rhyolitic inclusions have been widely recognised as shown in Figure 4.2. This observation requires explanation, as the interaction of a basaltic end-member melt with a melt of dacitic-rhyolitic composition would be expected to result in an andesitic melt if efficient mixing takes place. The Ngauruhoe lavas show evidence of repeated recharge that does not expel all melt from the system (discussed further in section 4.2), meaning that substantial mixing between mafic and felsic end-members must take place. 
Investigation of the petrology of rhyolitic flows from Medicine Lake Volcano by Grove and Donnelly-Nolan (1986) found that the final stage of crystallisation from high-silica andesite to rhyolite occurred at low pressure (1-2 kbar) along a cotectic that was nearly horizontal in temperature-composition space, resulting in a compositional gap between andesite and rhyolite. This led to the suggestion that similar processes may be responsible for the bimodality observed at other volcanoes. Further work by Reubi and Blundy (2009) using experimental liquid lines of descent at pressures ranging from 1-7 kbar found similarly shallower cotectics at andesitic compositions (Figure 4.3). The dacitic melt inclusions observed in the Ngauruhoe clinopyroxenes may therefore be explained by a system where following mafic recharge, the chemistry and physical conditions in the shallow magma chamber are such that the liquidus in temperaturecomposition space is shallow or near-horizontal, resulting in large amounts of fractional crystallisation over small decreases in temperature as the magma cools. This forces the composition of the remaining melt rapidly toward dacitic-rhyolitic chemistries rather than allowing it to remain at andesitic compositions for any substantial length of time. If this is the case, the magma that remains in the shallow plumbing system between successive recharge events is most likely of dacitic composition within the range exhibited by the clinopyroxene melt inclusions. Alternatively, there is the possibility that that the melt inclusions have been forced toward more silicic compositions due to post-entrapment crystallisation against the edges of the inclusion. Care was taken to avoid analysis of any melt inclusions that showed signs of post-entrapment crystallisation, but growth of the host crystal itself from the inclusion may be difficult to recognise. Also, given the prevalence of inclusions affected by post-entrapment titanomagnetite crystallisation, there is a possibility that some inclusions may have experienced titanomagnetite growth above or below the plane of the thin section that could not be identified. There is a strong evidence for bimodality in the crystal population, however, which lends support to a scarcity of intermediate melt in the system. The shallow cotectic model offers an explanation for this observed bimodality, which would be otherwise difficult to explain in conjunction with the evidence for frequent recharge and mixing of the end member melts. 


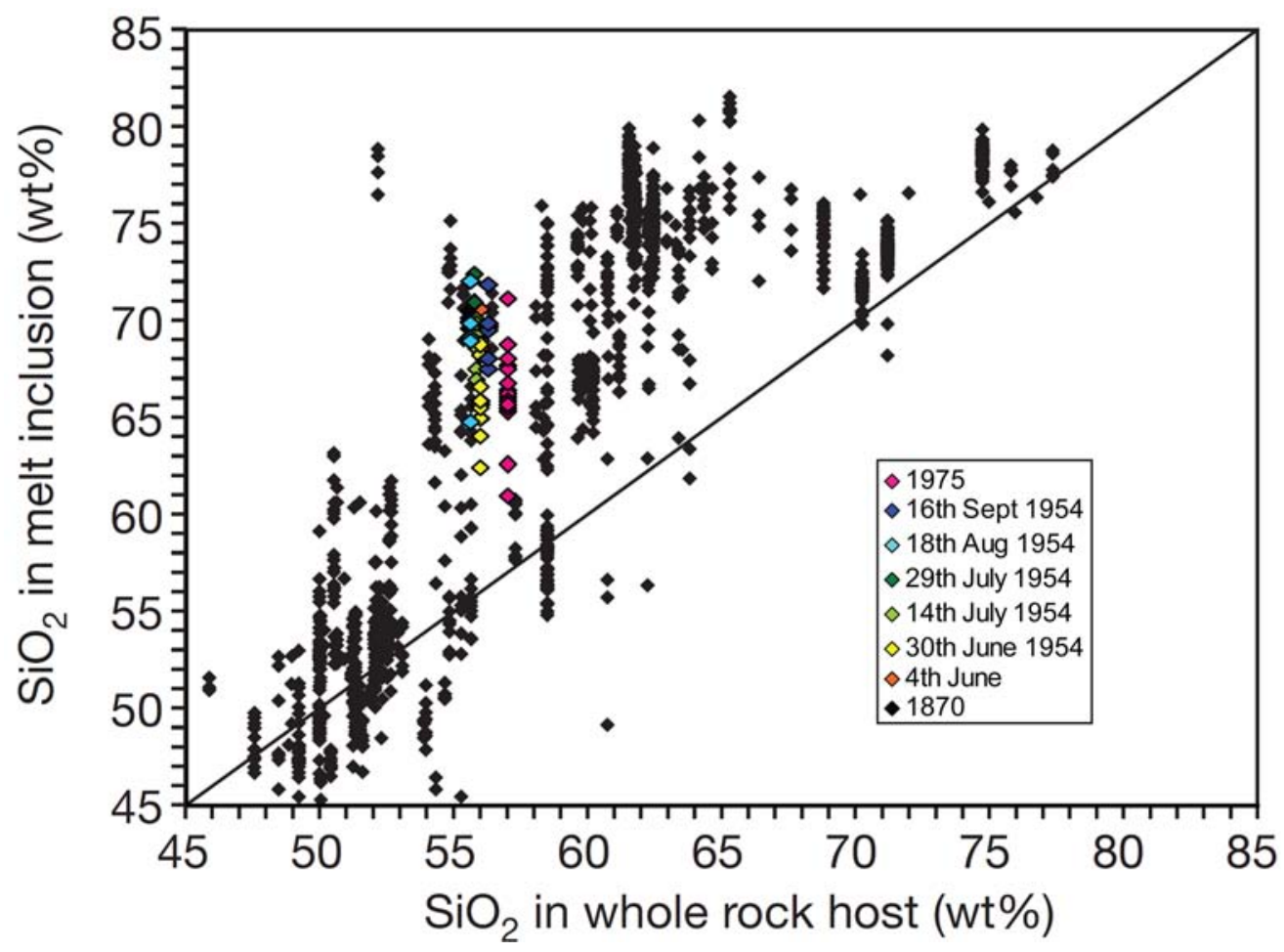

Figure 4.2: Diagram of melt inclusion $\mathrm{SiO}_{2}$ contents plotted versus whole-rock $\mathrm{SiO}_{2}$ from Reubi and Blundy (2009) showing that lavas of andesitic whole-rock composition commonly contain melt inclusions of dacitic to rhyolitic composition, lacking any andesitic or basaltic inclusions. The data are volcanic arc rock analyses from North, Central and South America, sourced from the GEOROC database. Ngauruhoe clinopyroxene melt inclusion data has been added to the diagram (coloured diamonds).

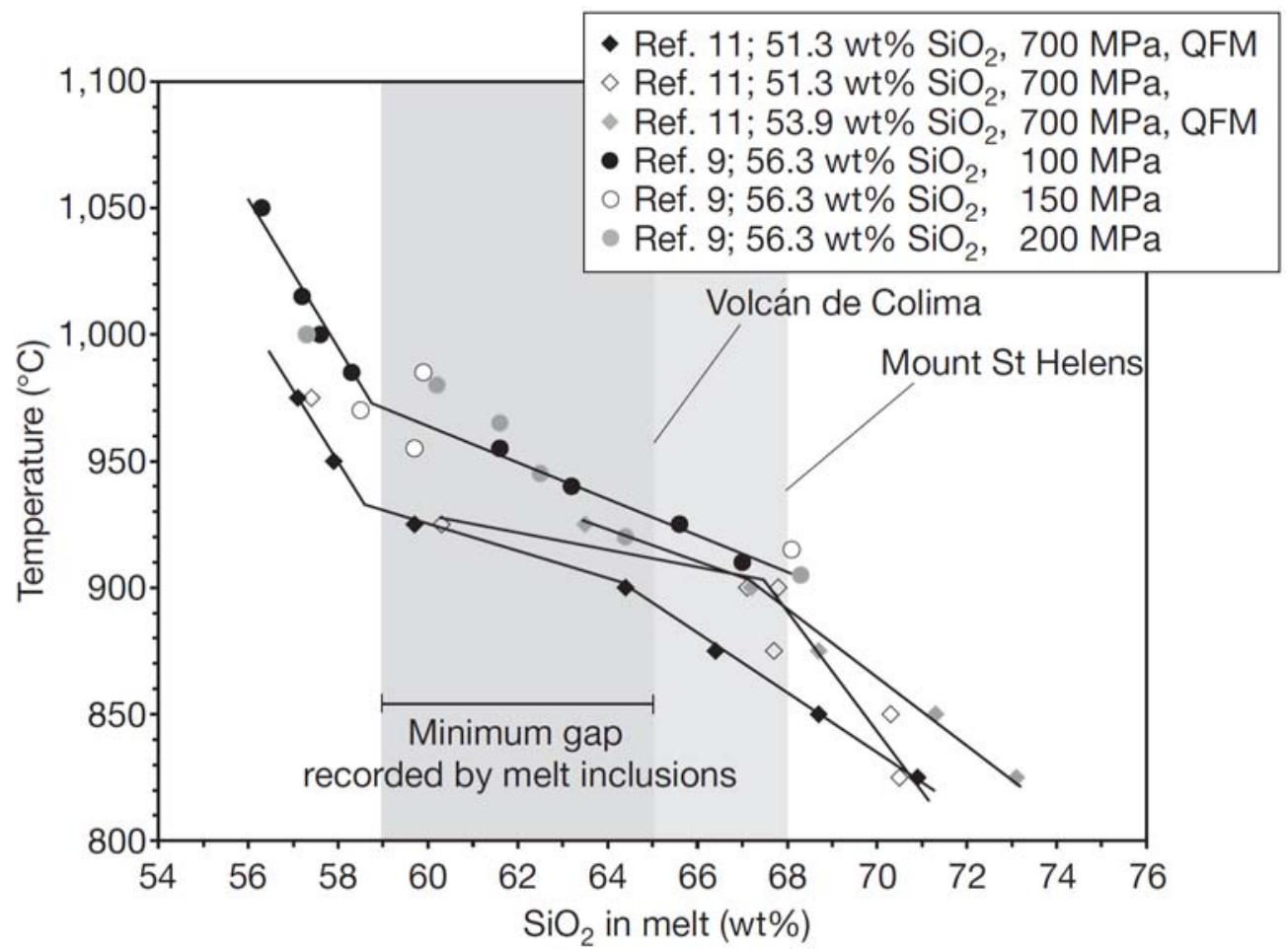

Figure 4.3: Graph showing experimental liquid lines of descent calculated for a range of pressures and starting compositions. The grey areas represent the compositional gap observed in the melt inclusion data, with Volcán de Colima marking the minimum extension of the gap, while Mount St Helens represents the common width of the gap at arc volcanoes. Figure taken from Reubi and Blundy (2009). 


\subsection{Origins of the crystal population}

\subsubsection{Interpretations based on mineral chemistry}

\section{Clinopyroxene}

Mg-rich clinopyroxene cores range from Mg\# 80-90. This is a slightly larger range than given in Gamble et al. (1990) for the Red Crater and K-trig basalts from the TVZ (Mg\# 83-88), but is consistent with a basaltic origin for the cores (Figure 4.4). There is some bimodality of Mg\# evident: a histogram of Mg\# for all zones in all samples shows two peaks, one at Mg\# 72-74 and one at Mg\# 82-86 (Figure 4.5). In addition, the $\Delta \mathrm{Mg} \#$ histogram (Figure 3.2) has a distinct peak that suggests most crystals contain a maximum difference in Mg\# of 11-16 between different zones of the crystals, a range consistent with the gap between the bimodal peaks of the Mg\# histogram (Figure 4.5). This indicates that the majority of crystals analysed have experienced a range in chemistry similar to the difference between the bimodal peaks, although a number of crystals have experienced a smaller range (i.e. have grown entirely in either the more mafic or more felsic end member). Other crystals have experienced a difference in Mg\# up to twice as large $(\Delta \mathrm{Mg} \#$ of 30$)$.

$\mathrm{Cr}$ in clinopyroxene shows a markedly curved trend of decreasing concentration with decreasing Mg\# and increasing Ce, suggesting fractional crystallisation is an important process in the magma system: mixing, whether with a lower Cr melt or with assimilated country rock, would result in a linear trend. It is possible to fit the Cr-Ce curve well by modelling the fractional crystallisation of phases in the system using a partition coefficient of 2.6 for $\mathrm{Cr}$ (Figure 4.6), but it would require $>90 \%$ fractional crystallisation to span the range in Cr concentrations. The partition coefficient used to back-calculate the melt concentrations of $\mathrm{Cr}$ from the Ngauruhoe clinopyroxene data needs to considerably higher than the 2.6 used to model the system in order to be realistic: partition coefficients smaller than $\sim 6$ would result in back-calculated melt compositions being more Cr-rich than a primitive basalt. However, if plagioclase crystallisation is occurring simultaneously with clinopyroxene crystallisation, then it is entirely plausible that the partition coefficient to model the decrease in $\mathrm{Cr}$ in the system would be considerably smaller than the partition coefficient for clinopyroxene alone, as 
Cr is highly incompatible in plagioclase. The model uses the highest $\mathrm{Cr}$ measured as a starting point for a parental composition. However, dropping the starting point as low as $600 \mathrm{ppm}$ to allow for the possibility that the highest $\mathrm{Cr}$ values measured may be erroneous would still require $>90 \%$ fractional crystallisation to encompass the range of data observed. A main drawback of the model is that it does not allow for the possibility of changing partition coefficients during the course of crystallisation, whether due to evolving chemistry or due to changes in the proportion of each phase that is crystallising, but the available partition coefficients for $\mathrm{Cr}$ are not sufficiently well constrained to take such factors into account. The evidence for control by fractional crystallisation given by the $\mathrm{Cr}$ data is in contrast to the wealth of textural evidence for magma mixing occurring in the system. However, below 600 ppm (back-calculated melt) $\mathrm{Cr}$ the curved relationship between $\mathrm{Cr}$ and Ce becomes considerably scattered, and it may be possible to link much of the data by straight mixing lines. It is possible then, that the $\mathrm{Cr}$ concentrations of the melt initially fall dramatically due to the crystallisation of phases in which $\mathrm{Cr}$ is compatible, such as clinopyroxene, orthopyroxene, olivine and Cr-spinel, and that mixing with more felsic melts does occur, but not until Cr concentrations have fallen considerably (this would be following $\sim 40 \%$ fractional crystallisation using a partition coefficient of 2.6 for the system). Alternatively it may be that mixing, when it does occur, either occurs between magmas that are not of vastly different chemistry or the amount of magma involved is very large or very small such that resulting chemistries that fall far off the Cr curve are not observed. The dominantly curved trend of the data that continues even below 600 ppm may indicate that fractional crystallisation continues to play an important role, alongside any possible mixing of different magmas. 

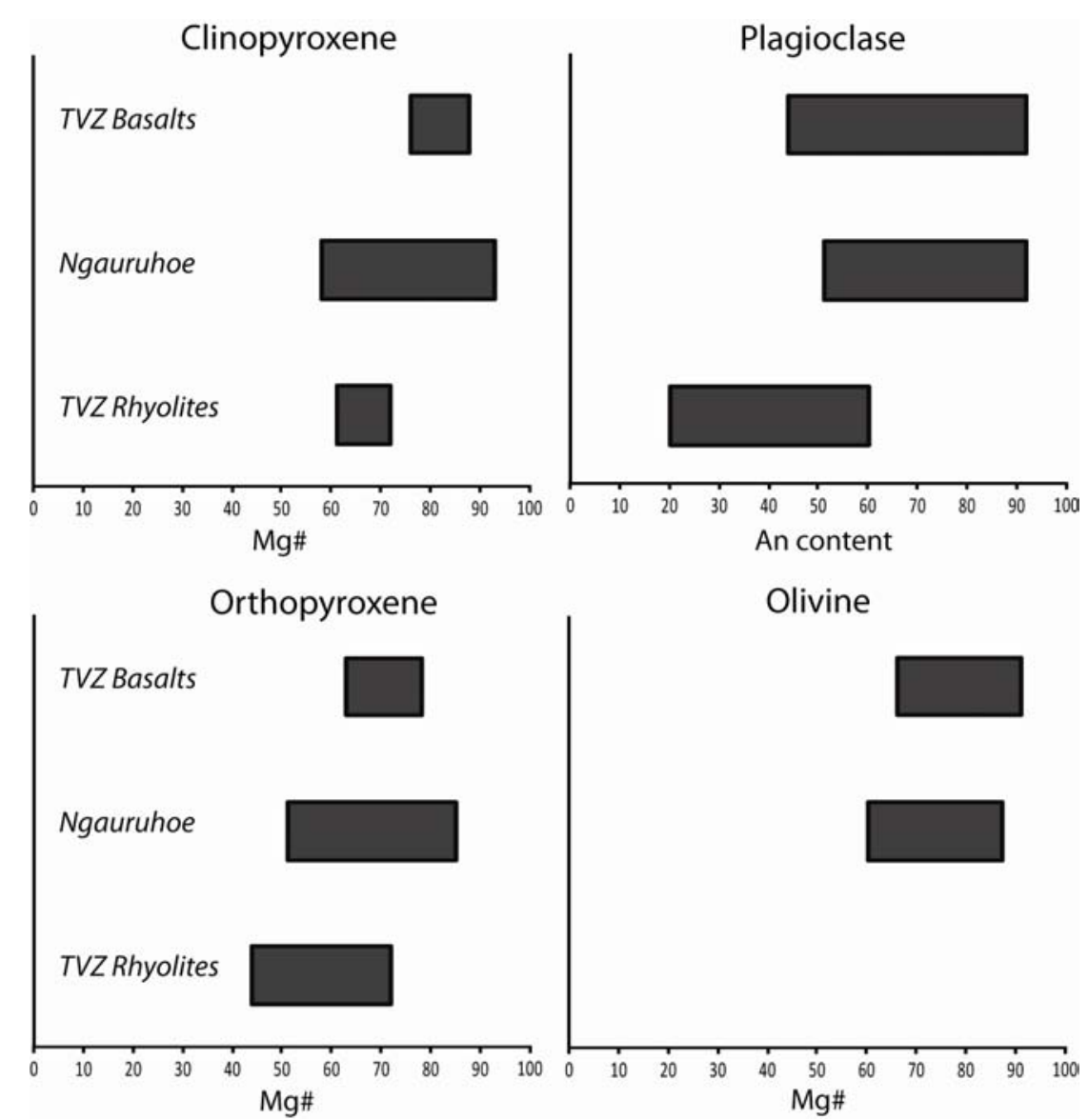

Figure 4.4: Diagram comparing the range in Mg\# and An of clinopyroxene, orthopyroxene, plagioclase and olivine observed in the zoning of the Ngauruhoe crystal population with measurements from the crystal populations of Taupo Volcanic Zone (TVZ) basalts and rhyolites. TVZ basalt data used are the Kakuki, Harry Johnson's, K-Trig, Red Crater, Waimarino and Ruapehu basalts from Gamble et al. (1990). Ranges for TVZ rhyolites include data for the Oruanui, Whakamaru, and Rotorua rhyolitic eruptions sourced from Brown et al. (1998), Sutton et al. (2000), Smith et al. (2004), Wilson et al. (2006), and Saunders et al. (2010).

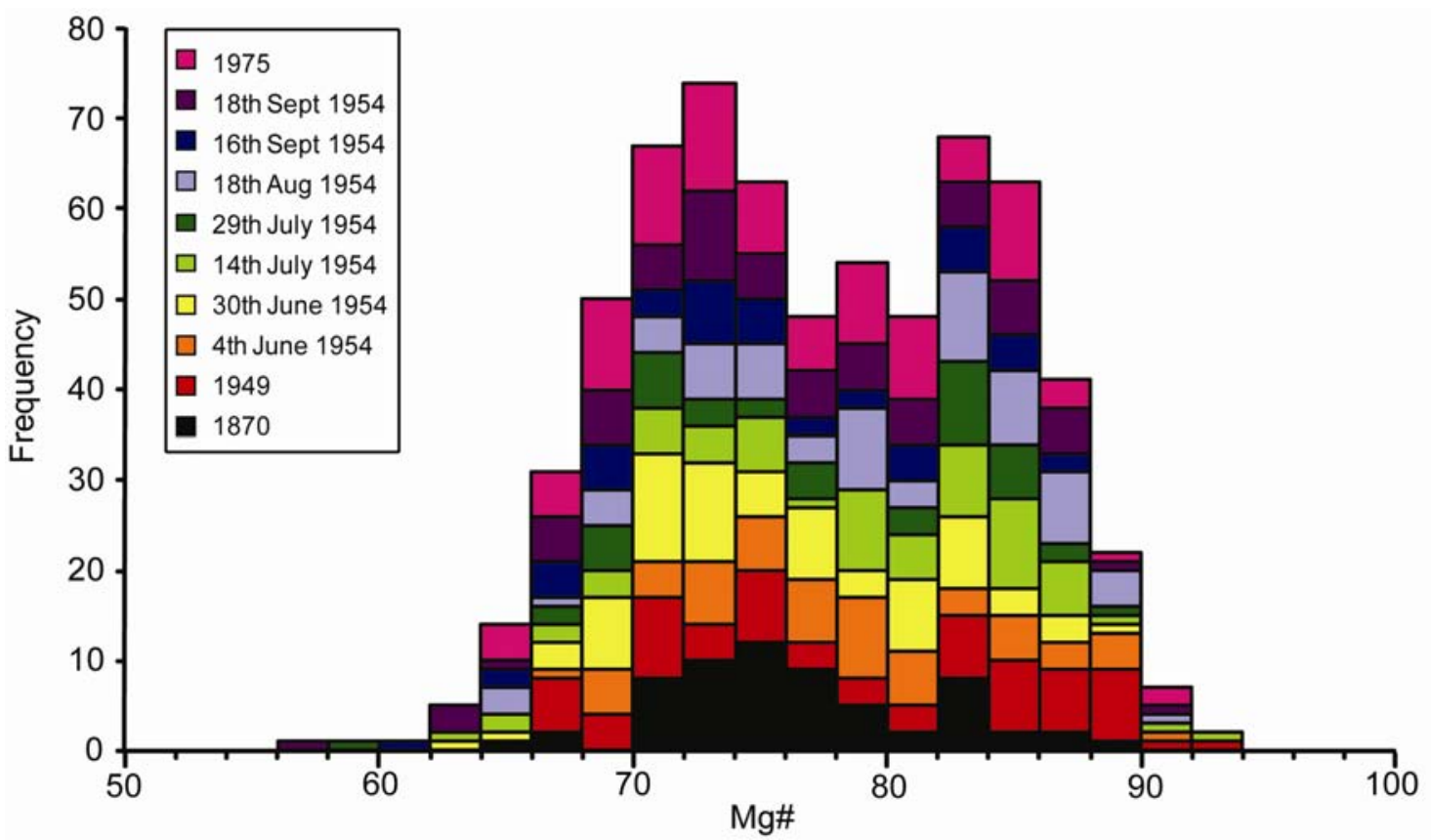

Figure 4.5: Histogram of clinopyroxene Mg\# of clinopyroxene analyses, with all samples on one graph to illustrate the overall bimodal nature of the data set. 

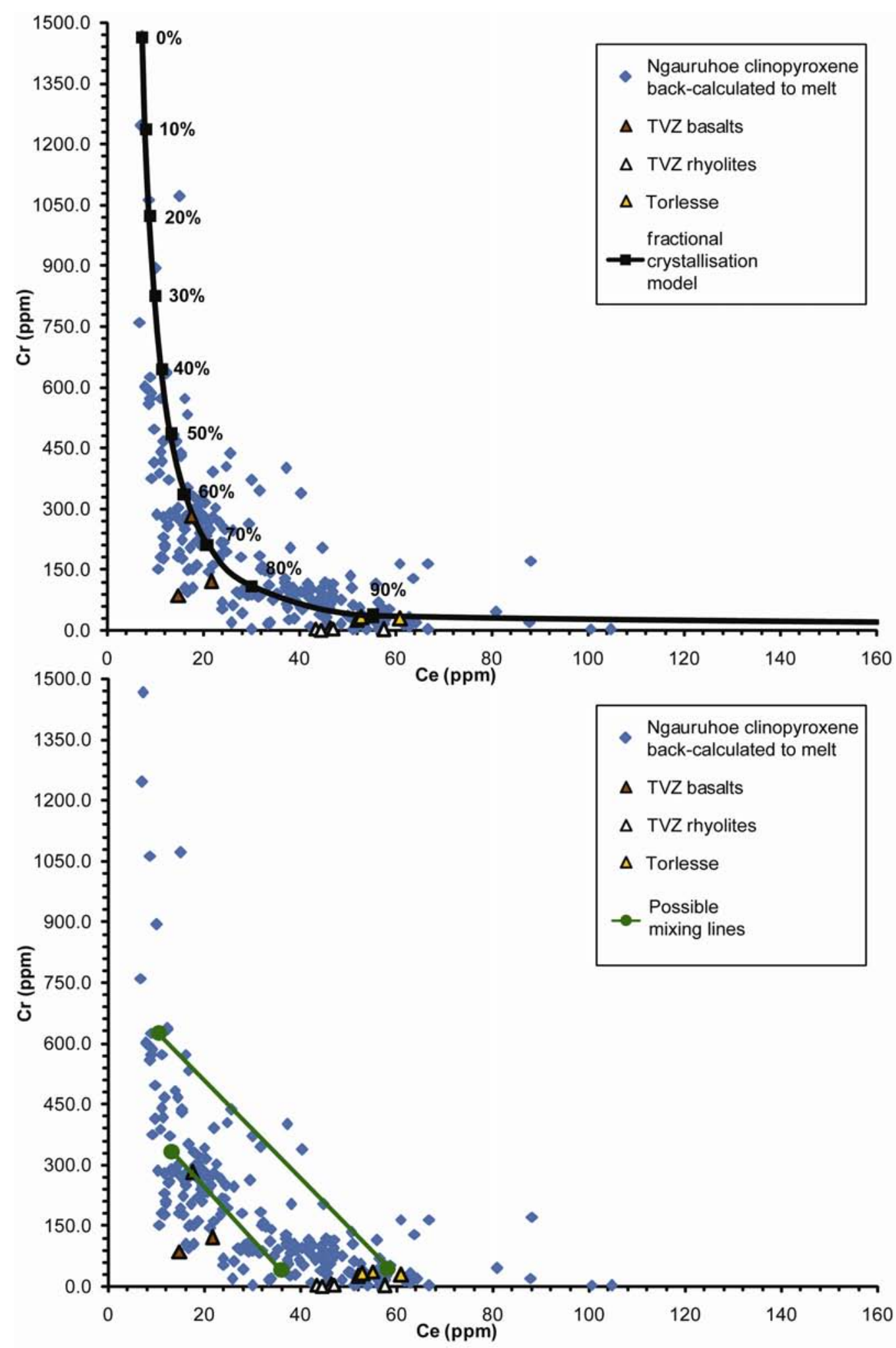

Figure 4.6: Top: Graph of back-calculated $\mathrm{Cr}$ melt (using a partition coefficient of 6) versus backcalculated Ce melt (using a partition coefficient of 0.114 from Zajacz and Halter (2007)) concentrations with whole-rock data plotted for TVZ basalts (Gamble et al., 1993), glass shard data for TVZ rhyolites (Allan, 2008) and whole-rock data for Torlesse greywacke of the Rakaia subterrane (Roser and Korsch, 1999). Fractional crystallisation modelling uses the highest $\mathrm{Cr}$ value as a starting point, and models the increase of $\mathrm{Cr}$ and $\mathrm{Ce}$ in the melt as fractional crystallisation progresses using the a partition coefficient of 2.6 for $\mathrm{Cr}$ and 0.114 for Ce. Bottom: graph illustrating schematically how linear mixing lines might also be able to explain much of the data, and account for the scatter of the data observed below $600 \mathrm{ppm}$ Cr. 
Despite also being compatible in both olivine and clinopyroxene, graphs of clinopyroxene Ni content look quite different from those of Cr (Figure 3.12). There is no clear fractional crystallisation curve to the Ni data; instead the data produce more of a triangular shape with decreasing Mg\#. Whilst some of the scatter may be due to analytical error, the upper spread of the data form a relatively straight line, particularly when plotted against Ce rather than Mg\#. Analytical error would not result in such a straight line, and it is likely that it therefore represents a mixing line between $\mathrm{Ni}$ rich melts and more evolved melts. The lack of a dominant trend in the Ni data may therefore lend support to the idea that combined mixing and fractional crystallisation processes are important in the Ngauruhoe magma system, as opposed to one process dominating. The drop in Ni content prior to mixing occurring does not appear to be as marked as it is for Cr. This may be caused by Ni not being as compatible in the crystallising phases as Cr. If this is the case, it may suggest that olivine crystallisation is less important than clinopyroxene crystallisation, if it occurs at all, as partition coefficients for $\mathrm{Ni}$ in olivine are generally higher than those for $\mathrm{Cr}$, and combined with clinopyroxene crystallisation should lower the Ni in the melt dramatically.

Although V and Sc are compatible in clinopyroxene, both of these elements increase linearly with decreasing Mg\# (Figure 3.12), indicating that the crystallisation of other phases in which these elements are incompatible takes place throughout the clinopyroxene crystallisation period. There are no kinks in the data to suggest the sudden arrest or onset of crystallisation of any phase with a greatly different partition coefficient for V or Sc. Y and Zr similarly increase with decreasing Mg\#. However, there are minor changes in the gradients of these graphs: the gradient of the $\mathrm{Y}$ versus Mg\# relationship increases from Mg\# 60-80 relative to Mg\# 80-90 (i.e. at Mg\# 60-80, Y increases more quickly with decreasing Mg\#) while the Zr gradient decreases slightly for the same Mg\# ranges. This change becomes more evident when $\mathrm{Zr} / \mathrm{Y}$ is plotted as a ratio (Figure 3.12). Interestingly, Mg\# 80, where the change in gradient takes place, corresponds to the midpoint between the two peaks in Mg\# on the clinopyroxene $\mathrm{Mg \#}$ histogram (Figure 4.5). 
Sr/Nd ratios back-calculated to melt compositions (using partition coefficients from Zajacz and Halter, 2007) were plotted against Ce as an indicator of plagioclase fractionation. As with $\mathrm{Cr}$, the resulting trend is curved, with $\mathrm{Sr} / \mathrm{Nd}$ decreasing as Ce increases as would be expected as $\mathrm{Sr}$ is removed from the melt into crystallising plagioclase, while $\mathrm{Nd}$ and Ce increase due to their incompatibility in the crystallising phases. Fractional crystallisation modelling was carried out using partition coefficients for plagioclase. A partition coefficient of 1.286 was used for Sr, calculated from Blundy \& Wood (1991) using $\mathrm{An}_{90}$ (as fractional crystallisation would commence from the most mafic conditions) and a temperature of $1050^{\circ} \mathrm{C}$ as this is close to the mean temperature of $1048^{\circ} \mathrm{C}$ calculated for all lava flows using the two-pyroxene geothermometer from Putirka (2008). Nd and Ce partition coefficients used in the model of 0.0835 and 0.0774, respectively, were calculated from Bindeman et al. (1998). The fractional crystallisation model fits the data well, but as with the modelling for Cr, would require $>90 \%$ fractional crystallisation to cover the range of all data points (Figure 4.7). Mixing modelling using the highest and lowest Sr/Nd of the backcalculated melt data as end member compositions produces a curve that is too shallow to fit the Ngauruhoe data. However, the model becomes a better fit when the high $\mathrm{Sr} / \mathrm{Nd}$ and high Ce tails of the curve are not included, i.e. when the mixing is modelled (not shown) between a melt with $\mathrm{Sr} / \mathrm{Nd}$ of 45 and one with Ce of $\sim 65 \mathrm{ppm}$ rather than using the full range of the data. Thus, as $\mathrm{Sr} / \mathrm{Nd}$ is a ratio rather than a single element, the mixing relationship is also curved rather than being a straight line as it would be on a bivariate plot, and mixing may in fact be able to explain much of the $\mathrm{Sr} / \mathrm{Nd}$ variation in the data. However, the inability of the mixing model to explain the full range of variation exhibited by the data also necessitates the involvement of substantial fractional crystallisation within the system. 


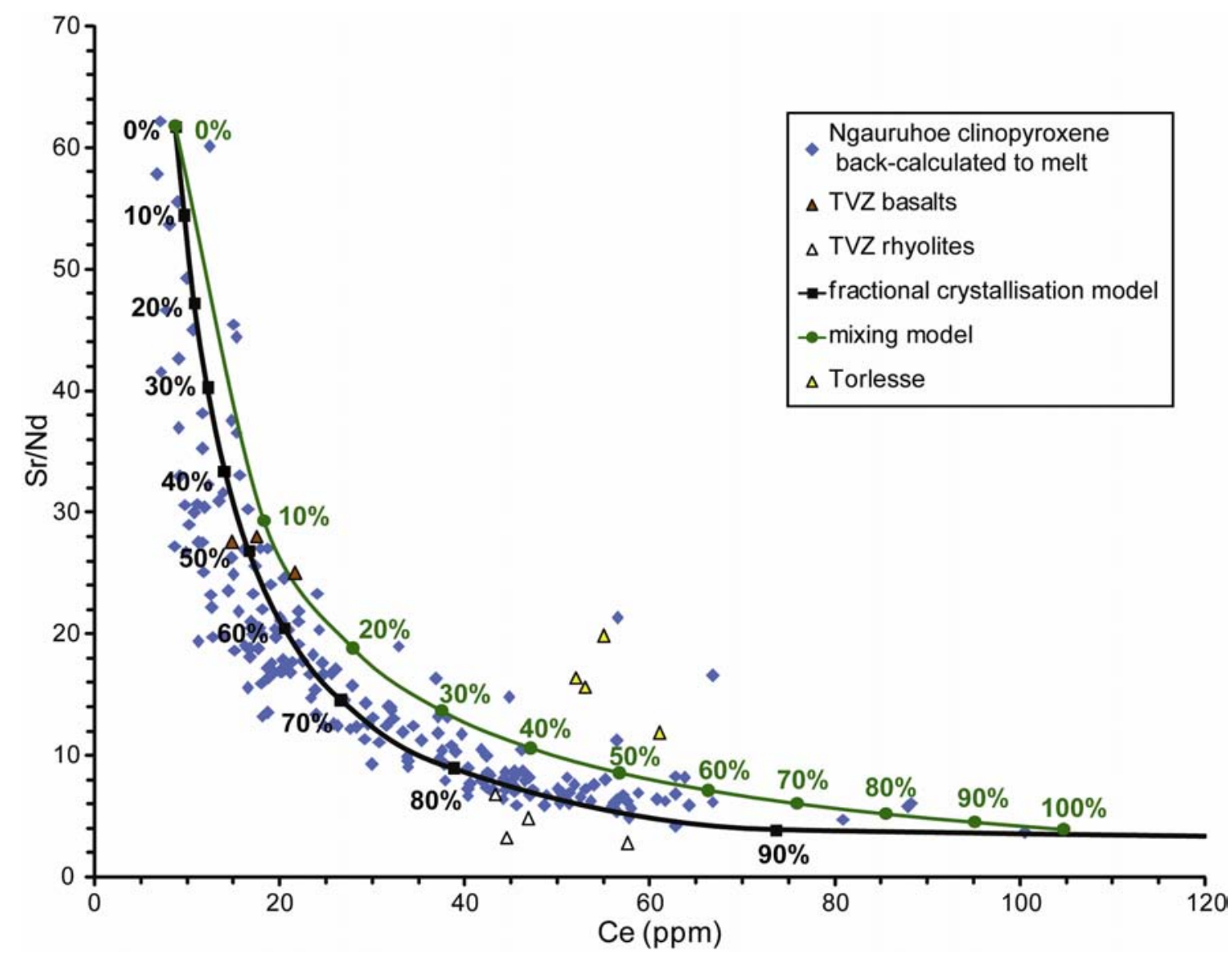

Figure 4.7: Graph of back-calculated melt Sr/Nd (using partition coefficients of $0.065 \mathrm{Sr}$ and 0.285 for $\mathrm{Nd}$ ) versus back-calculated melt Ce (using a partition coefficient of 0.114). These partition coefficients were taken from Zajacz and Halter (2007). Whole-rock data for TVZ basalts (Gamble et al., 1993), glass shard data for TVZ rhyolites (Allan, 2008) and whole-rock data for Torlesse greywacke of the Rakaia subterrane (Roser and Korsch, 1999) have also been plotted. Fractional crystallisation modelling uses a Ngauruhoe measurement as a starting point, and models the decrease of $\mathrm{Sr} / \mathrm{Nd}$ with increasing $\mathrm{Ce}$ in the melt as fractional crystallisation progresses. The fractional crystallisation model uses a partition coefficient of 1.286 for Sr (Blundy and Wood, 1991). Nd and Ce partition coefficients used in the model of 0.0835 and 0.0774 respectively were calculated from Bindeman et al. (1998).

Clinopyroxene mineral chemistry was also used for the calculation of temperatures and pressures of crystallisation for the Ngauruhoe magma system (Appendix 4), using the two-pyroxene geothermobarometers of Putirka (2008). Whilst the temperatures calculated using this method of $1032-1064^{\circ} \mathrm{C}$ are not unreasonable and are comparable to other temperature estimates for Ngauruhoe, the pressures calculated range from $\sim 0.3-$ 3.7 kbar. Assuming an average density of $2700 \mathrm{~kg} / \mathrm{m}^{3}$ for the rocks in the region, this would equate to depths ranging from $1-14 \mathrm{~km}$. This is a very large range, particularly given that only rim data were used, and is most likely predominantly a reflection of the errors associated with two-pyroxene barometry rather than an indication that rims 
crystallised at greatly different levels in the crust. Seismic tomography work by Rowlands et al. (2005) suggested that the presence of low velocity material occurring at 3-8 km depth beneath Mt Ngauruhoe is the result of a complex of hot or partially molten material left over from previous eruptions, potentially in the form of a network of interconnected conduits and small magma chambers in line with the geochemical interpretations of Hobden et al. (1999). The authors also acknowledge the possibility that a hydrothermal system or hydrothermal alteration of the rock during previous eruptive episodes contributes to the low velocity volume. While this provides some insight into the nature of the Ngauruhoe plumbing system, it does not aid the determination of where initial fractional crystallisation of the more mafic end member might take place and at what depths it interacts with more felsic components.

Trace element data measured in zoning in the historical Ngauruhoe clinopyroxene crystal populations all follow the same trends, not only within a single lava flow, but for all lava flows erupted in the $>100$ year window from 1870-1975. This suggests that, despite the abrupt changes in whole-rock major element and $\mathrm{Sr}$ isotopes between lava flows that were measured in previous studies (Hobden et al., 1999; Hora, 2003), the magma input and processes occurring in the plumbing system have remained relatively constant throughout the historical eruption period. Changes in whole-rock chemistry may simply relate to differences in the quantity and frequency of mafic recharge events, the extent to which fractional crystallisation and crustal assimilation have occurred in the upper regions of the magma system shortly prior to eruption, and the proportion and nature of the crystal cargo.

\section{Orthopyroxene}

Orthopyroxene cores have Mg contents up to Mg\# 85 - this is considerably higher than measurements made in the Red Crater basalt by Gamble et al. (1990) and Hobden (1997) which reach a maximum of only Mg\# 78. Orthopyroxene is not present in either the Kakuki or K-trig basalts (Gamble et al., 1990). Ngauruhoe orthopyroxene Cr contents reach a maximum of only $0.35 \mathrm{wt} \%$ in comparison to the $0.87 \mathrm{wt} \%$ measured in clinopyroxene, but only 11 clinopyroxene analyses lie in the range 0.35-0.87 wt\%, 
and orthopyroxene still exhibits a clear fractional crystallisation curve with analyses dropping rapidly from $0.35 \mathrm{wt} \%$ down to $0.2 \mathrm{wt} \%$ at almost the same Mg\#. It is therefore possible that the most Mg-rich cores crystallised at a similar time to the mafic olivine, clinopyroxene and plagioclase components, and were transported into more silicic melt alongside them. However, the proportion of orthopyroxene crystals with mafic cores is lower than for plagioclase and clinopyroxene, indicating that a larger portion of the orthopyroxene crystal population has crystallised in more evolved melt.

As discussed in Chapter 2, some orthopyroxene crystals have cores that are anomalously Fe-rich and low in CaO. These cores are not common, but occur in samples erupted 80 years apart, suggesting that while they do not play an important role in the magma system, the process that gives rise to them is an ongoing one. The Mg\# of these cores ranges from 45-55, as low as orthopyroxene of dacitic to rhyolitic origin, but the $\mathrm{CaO}$ contents of 0.2-0.7 fall below that measured in Taupo volcanic zone dacites and rhyolites (Brown et al., 1998; Cole et al., 2001; Smith et al., 2004). In addition, the cores exhibit opposite trends in $\mathrm{TiO}_{2}$ as compared to the rest of the Ngauruhoe orthopyroxene data. These orthopyroxene crystals are clearly xenocrystic to the Ngauruhoe system, indicating the influence of wall rock or other magmas, but their origin is difficult to explain. Basement beneath Mt Ngauruhoe is believed to consist of sandstones of the Torlesse terrane which are predominantly of quartzofeldspathic composition and not confirmed to contain any pyroxene.

\section{Plagioclase}

The range in anorthite content of calcic cores $\left(\mathrm{An}_{79-92}\right)$ from the historical Ngauruhoe plagioclase is consistent with the most calcic plagioclase measured in the Kakuki and K-trig basalts (Gamble et al., 1990). Back-calculated melt Sr values determined using the partition coefficient from Blundy and Wood (1991) cover the same range ( 120-420 ppm) as back-calculated clinopyroxene values (determined using the partition coefficient from Zajacz and Halter, 2007), suggesting that they have, at least for the most part, shared a common crystallisation history. Clinopyroxene cores reach slightly higher back-calculated Sr concentrations and plagioclase extends to slightly lower 
concentrations. However, this may be an effect of the partition coefficients not necessarily being the most accurate for this particular magmatic system, rather than an indication that clinopyroxene crystallisation commenced prior to that of plagioclase. Whilst investigation of the petrology of TVZ basalts indicates that plagioclase crystallisation may often commence prior to that of clinopyroxene (Gamble et al., 1990), this is not necessarily the case for Ngauruhoe. Trace element analyses of the Ngauruhoe clinopyroxenes show a steep drop in back-calculated $\mathrm{Sr} / \mathrm{Nd}$ with $\mathrm{Mg \#}$ observed in the most magnesian clinopyroxenes (Figure 3.12) indicating that $\mathrm{Sr}$ is already being removed from the melt, and the $\mathrm{Eu}$ anomaly becomes increasingly negative with decreasing Mg\#, once again from the clinopyroxene with highest $\mathrm{Mg \#}$ (Figure 3.12). However, the initially high Sr values, and Eu/Eu* 1 of $\mathrm{Mg}$-rich clinopyroxene cores suggests that plagioclase crystallisation commenced at a similar time to clinopyroxene. Had it commenced significantly earlier, Eu/Eu* anomalies would be expected to be markedly lower than one (a negative Eu anomaly) due to the incorporation of divalent Eu into the plagioclase crystal lattice.

As with the Mg\# of clinopyroxene analyses, the anorthite content of plagioclase analyses exhibits a marked bimodality (Figure 3.5). This bimodality is largely a reflection of the dominance of calcic cores mantled by sodic rims, but sodic cores are not uncommon and zoning that occurs between the cores and rims of crystals spans the entire range from the most calcic to most sodic compositions. However, rim chemistry does not approach the most calcic compositions. In some cases, crystals possess a very thin rim that has more calcic composition than adjacent inner zoning (Figure 4.8), but the anorthite of these rims does not reach values as high as the high-An peak on the histogram that corresponds to core composition. Such rims were too narrow for trace elements to be measured via LA-ICP-MS, making it difficult to ascertain whether the increase in anorthite is more likely the result of physical or chemical changes in the melt. However, similarly thin Mg-rich outermost rims on clinopyroxene crystals were found to have increased $\mathrm{Cr}$ content. As with plagioclase anorthite, the $\mathrm{Cr}$ content of these thin clinopyroxene rims does not reach concentrations as high as core material. This would indicate that significant changes in magma chemistry due to mafic recharge 
shortly prior to eruption occurred, and a chemical change may similarly be involved in the increased An seen in some plagioclase rims, but that such events are either not large enough to cause a return to the most mafic conditions or are of more evolved chemistry.

Whilst the histogram in Figure 3.5 clearly indicates that inner zoning of plagioclase often does overlap with core anorthite compositions, such zones are generally adjacent or close to the core and occur only as part of normal zoning. Regardless of the size of the zone and extent of disequilibrium textures, no calcic zone that occurs as reverse zoning against an inner sodic zone approaches anorthite contents similar to the first peak. At most, such reverse zones reach $\sim \mathrm{An}_{80-81}$. This suggests that following initial crystallisation of the most mafic cores, crystals are never again exposed to such conditions (mafic chemistry and/or high temperatures and pressures) despite multiple significant recharge events occurring. This may indicate that following core crystallisation the crystal cargo is moved into a new area of the plumbing system. If crystals remained in a lower crustal crystal mush environment, chemistries as primitive as the cores might be expected to be attained with subsequent recharge events, due to the processes and conditions being more similar to those of initial crystallisation and due to the lower proportion of melt relative to crystals meaning that recharge events would have a greater effect on melt chemistry than in a melt-dominated environment. Alternatively, while it is possible that crystals remain in one area of the plumbing system for mafic core crystallisation and subsequent growth of more evolved zoning, this would require that all crystals be expelled prior to any renewed mafic core crystallisation for future eruptions, i.e. that there is no crystal recycling. If there were recycling of crystal populations, chemistries as mafic as the cores would be found as zones on the recycled crystals. An alternative suggestion by Hora (2003) was that the cores may originate from an older basaltic system beneath Ngauruhoe, and throughout the volcano's more recent history these older basaltic cores have been repeatedly remobilised by a more felsic melt, leading to the observed bimodality of anorthite. This proposal is addressed in more depth in the discussion on plagioclase textures (section 4.2.2), but it is worth noting that for all trace and major elements measured, the mafic cores lie on the same trends as all other zoning. This would suggest that if there were 
any older basaltic system beneath Ngauruhoe which has given rise to these cores, it had precisely the same chemistry as current mafic recharge events, as these events force zoning back toward such chemistries. With this in mind, the simplest explanation for the origin of the cores would be that they are introduced into the more felsic melt as a component of these mafic recharge events; it seems entirely unnecessary to invoke the involvement of a separate magmatic system.

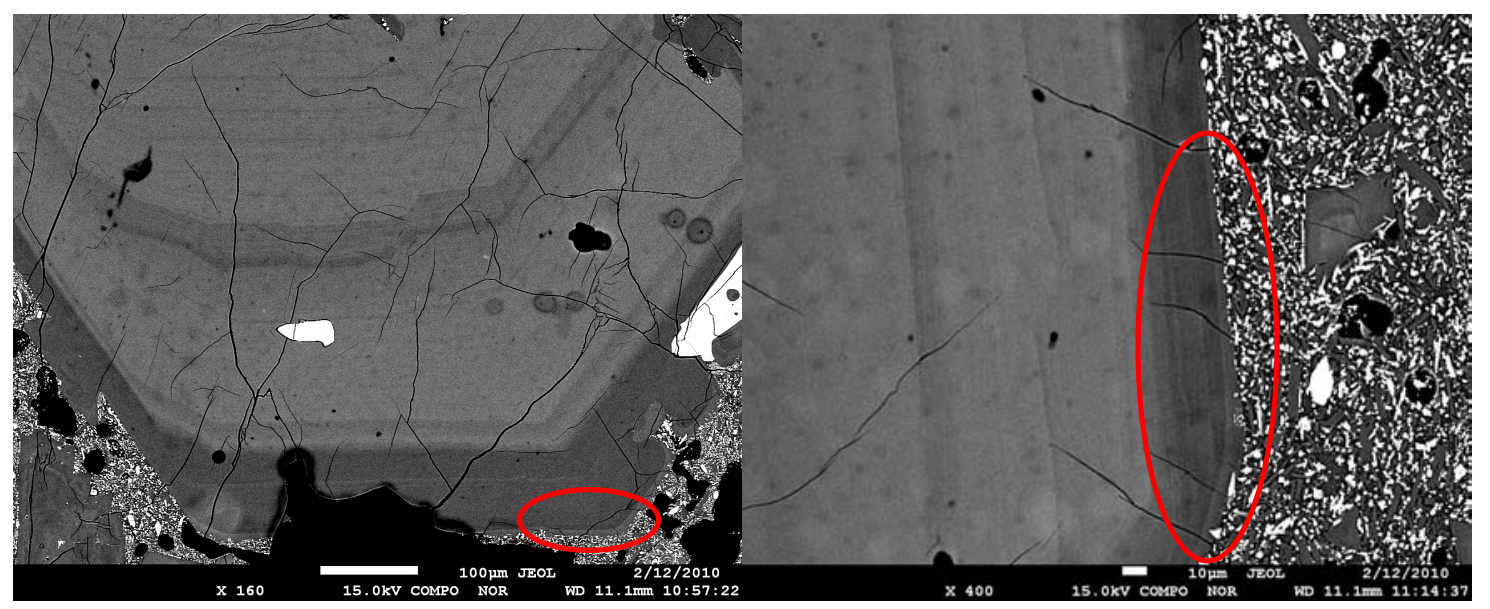

Figure 4.8: Images of plagioclase crystals from the 1949 lava flow that possess thin outermost rims that are more calcic than adjacent inner zoning. Red ellipses have been used to highlight these rims.

$\mathrm{Rb} / \mathrm{Sr}$ increases with decreasing anorthite (Figure 3.14), indicative of fractional crystallisation processes. However, there is considerable scatter of the data at higher $\mathrm{Rb} / \mathrm{Sr}$ (below $\sim \mathrm{An}_{72}$ ). This is opposite to what might be expected due to analytical error, as $\mathrm{Rb}$ is at higher concentrations and is easier to measure precisely. There is the possibility that the scatter may simply be due to there being more data at higher $\mathrm{Rb} / \mathrm{Sr}$. Alternatively, it may indicate the involvement of crustal assimilation processes alongside fractional crystallisation processes to produce the more evolved end-member below $\mathrm{An}_{72}$, as Torlesse greywacke generally has considerably lower $\mathrm{Rb} / \mathrm{Sr}$ than $\mathrm{TVZ}$ rhyolites. Torlesse whole-rock analyses from Roser and Korsch (1999) have Rb/Sr 0.180.38, whilst whole-rock TVZ rhyolite analyses from Sutton et al. (1995) have Rb/Sr 0.43-1.89, with the majority in the range 0.61-0.94. 


\section{Olivine}

The cores of olivine crystals in the historical Ngauruhoe lava flows have forsterite contents that largely overlap those measured in TVZ basalts, supporting a mafic origin for the crystals (Figure 4.4). However, they extend to considerably more Fe-rich values. The lowest forsterite content given in Gamble et al. (1990) for olivines from TVZ basalts is $\mathrm{Fo}_{66}$, for some of the olivine crystal population from the Kakuki basalt. A large portion of the Ngauruhoe olivine cores analysed in this study lie in the range $\mathrm{Fo}_{60}$ $\mathrm{Fo}_{66}$, suggesting they have experienced considerably more evolved conditions than those of the TVZ basalts, although it is possible that the crystals have been affected by diffusive re-equilibration rather than necessarily crystallising in a more Fe-rich melt.

Like clinopyroxene and plagioclase, olivine analyses also show evidence of bimodality (Figure 3.7). Two samples of the ten lava flows studied do not appear to be bimodal, however. A number of the olivine cores analysed in the $16^{\text {th }}$ September 1954 and in particular in the $18^{\text {th }}$ August 1954 lava flow have olivine cores with Mg\# 68-77: the range that represents a compositional gap for many of the other lava flows. It is interesting to note that the $18^{\text {th }}$ August 1954 lava flow also contains a number of clinopyroxene analyses with Mg\# that falls in the centre of the clinopyroxene 'compositional gap', i.e. between the bimodal peaks in Mg\# evident in the histogram of Figure 4.5.

\section{Fe-Ti Oxides}

Titanomagnetite that occurs as a separate crystal phase surrounded by groundmass is considerably more Ti-rich than that which occurs as inclusions within other mineral phases (Figure 3.8). However, the wt\% MgO of titanomagnetite that occurs as inclusions in plagioclase is distinctly lower than that of inclusions within the more Mgrich phases (olivine, clinopyroxene, and orthopyroxene). This may indicate that significant re-equilibration has occurred between mineral hosts and titanomagnetite inclusions, at least for some elements. Thus, whilst the chemistry of titanomagnetite that occurs in the groundmass may provide reasonably sound information about the conditions of the final melt and was found to correlate well with groundmass glass data, 
titanomagnetite that occurs as inclusions in the crystal phases cannot be relied upon to provide information about past melt conditions. The fact that titanomagnetite inclusions in the mineral phases have considerably lower X'Usp than those in the groundmass should not be taken to suggest that conditions as evolved as the final melt did not occur previously during the crystallisation period, particularly given the rapid rate of Fe-Ti interdiffusion in titanomagnetite (Freer and Hauptman, 1978) and the small size of the inclusions. 


\subsubsection{Interpretations based on mineral textures}

\section{Clinopyroxene}

Mafic clinopyroxene cores frequently contain abundant melt inclusions of more Fe-rich composition than the core material, and in many cases the core composition has been significantly altered to more Fe-rich chemistry by diffusive re-equilibration with these inclusions. In addition, Mg-rich clinopyroxene cores are generally rounded, wavy and embayed. The high $\mathrm{Cr}$ content of the cores (0.1-0.9 wt\%) in comparison with more Ferich regions (0-0.2 wt\%) suggests that the high $\mathrm{Mg \#}$ is due to growth in a more primitive melt as opposed to the core Mg\# being controlled by other factors. Thus, the dissolution of the cores prior to the growth of considerably more Fe-rich zoning and the lower $\mathrm{Cr}$ content of this zoning suggest movement of the crystals from a less evolved melt into a more evolved one. The abundance of these mafic cores may indicate that much of the clinopyroxene crystal nucleation occurs in a more primitive end member melt, a possibility that is supported by the absence of clinopyroxene microlites from the groundmass. Alternatively, there may be some re-assimilation of more Fe-rich cores during mafic recharge events.

Zoning of the clinopyroxene crystal population initially appears to be quite complex, as illustrated by the range of images provided in Chapter 2. Reverse zoning is common, and there is considerable variation in the number of zones in each crystal and in the widths of zones both within and between crystals. In some cases, mafic zones have partially resorbed inner felsic zones prior to crystallisation whereas in other cases no resorption is evident, and in some instances outer felsic zones have a wavy boundary against an inner more Mg-rich zone (e.g. Figure 2.14c). This complexity of zoning may provide some support for the model of small interconnected magma chambers suggested by Hobden et al. (1999), particularly given that a wide range in crystal zoning occurs even within a single eruption, making the identification of discrete crystal populations difficult. In general though, the major features of the clinopyroxene crystal population can be explained by a relatively simple model in which a mafic end member (clinopyroxene Mg\# 80-91) that has been subject to variable amounts of fractional crystallisation is repeatedly injected into a plumbing system containing more evolved 
melt (clinopyroxene Mg\# 65-76) with mixing and further fractional crystallisation allowing for the intermediate chemistries between the two end members. The abundance of reverse zoning (usually 1-3 events per crystal) indicates that mafic recharge events may occur frequently in the Ngauruhoe plumbing system. This observation is in line with the high levels of activity recorded at the volcano (Gregg, 1960).

The absence of clinopyroxene microlites from the groundmass, combined with the very thin rims of orthopyroxene that are sometimes observed on clinopyroxene crystals, indicates that the final melt prior to eruption has generally evolved to conditions not suitable for clinopyroxene crystallisation. This is at odds with the evidence for mafic recharge only weeks-months prior to eruption that is provided by the presence of thin Mg-rich rims on the clinopyroxene crystal population and the diffusion ages obtained from these boundaries.

\section{Orthopyroxene}

Mg-rich orthopyroxene cores are often diffuse and sometimes honeycombed, indicative of having experienced some resorption due to disequilibrium with the more Fe-rich melt that has formed adjacent zoning. The abundance of crystals with relatively simple zoning (Figure 2.15) may indicate that crystal recycling does not occur on a large scale as mafic crystals injected into more evolved material where they crystallise an Fe-rich zone, experience one more mafic recharge and are then erupted. Those crystals that are predominantly Mg-rich with only a very thin Fe-rich rim have most likely been introduced into the more felsic melt with most recent mafic injection prior to eruption, and formed only a thin Fe-rich rim as a result of this.

The dissolution texture observed towards the rims of a number of the orthopyroxene crystal population is not dissimilar to that described in Streck (2008) as having 'inverted stratigraphy’ (Figure 4.9). This ‘inverted stratigraphy’ (that the Fe-rich core grew after the more Mg rich material that surrounds it) is inferred from the superposition of patches and spots of more Fe-rich material across the more Mg-rich region, and from the zoning of other orthopyroxene crystals throughout the thin section. However, 
applying such an explanation to similar textures in the Ngauruhoe orthopyroxenes does not seem to fit: for some crystals that exhibit this texture, the Fe-rich area appears to have formed prior to that of the outer more Mg-rich material it forms the texture with, as it forms a zone around an even more Mg-rich core (Figure 4.9). In such cases, it appears the more Mg-rich material must have only caused partial dissolution of the Ferich zone, leaving small patches of Fe-rich material. 


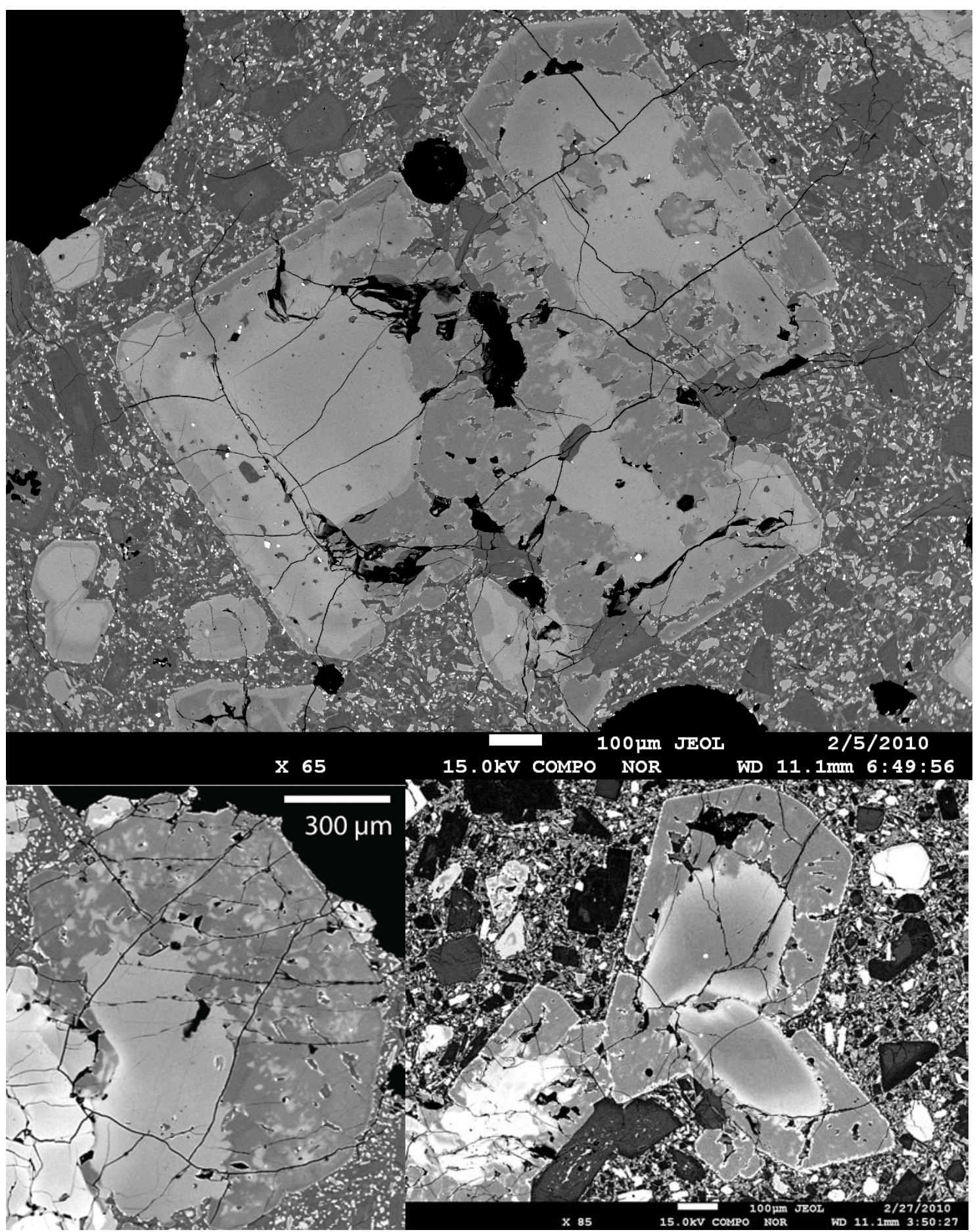

Figure 4.9: Comparison of the texture of a Ngauruhoe orthopyroxene from the $18^{\text {th }}$ August 1954 lava flow (top) with that of an orthopyroxene from Whaleback Volcano, California (bottom left). An orthopyroxene crystal from the $16^{\text {th }}$ September 1954 Ngauruhoe lava flow showing a similar texture (bottom right) clearly demonstrates the Fe-rich region to be a zone that has formed prior to the outermost region, indicating that the texture could not be an example of inverse stratigraphy and that such an interpretation does not apply to all Ngauruhoe orthopyroxenes exhibiting such a texture, if indeed it could be applied to any. The image of Whaleback Volcano crystal is taken from Streck (2008). 


\section{Plagioclase}

The plagioclase crystal population is dominated by calcic cores surrounded by more sodic zoning and rims, as described in section 2.3.3. Calcic cores frequently possess a patchy and/or sieved texture. Whilst sieve texturing is not limited to the cores, the sieve texturing that occurs in cores is generally of a coarser nature than that which occurs in other zoning. A number of authors differentiate between 'dusty' and 'honeycomb' textures (Kawamoto, 1992). A dusty texture consists of relatively fine melt inclusions, and is believed to be the result of the partial dissolution of Ab-rich plagioclase by melt that is in equilibrium with more An-rich plagioclase (Tsuchiyama, 1985). Honeycomb plagioclase has larger melt inclusions and there has been more debate over its origins, with suggestions as to its cause including magma mixing (Dungan and Rhodes, 1978), skeletal growth under supercooling conditions (Kuo and Kirkpatrick, 1982) and rapid decompression (Nelson \& Montana, 1992). The patchy texture of anorthite poor zones inside the calcic core is not dissimilar to those from the 1980 Mt St Helens eruptions that are described as 'boxy cellular' by Berlo et al. (2007). It has been suggested that a common cause for 'boxy cellular' textures may be skeletal growth, which is later infilled by lower anorthite melt that invades an open channel network in the pre-existing skeletal plagioclase (Berlo et al., 2007; Streck, 2008). However, Lofgren (1980) notes that skeletal growth is unlikely to be the cause in situations where the plagioclase in the cellular zones is rounded rather than squared, as rapid growth would favour crystallographic directions leading to straight edges. The patches in the Ngauruhoe plagioclase cores are generally irregular shapes and frequently rounded, suggesting dissolution as the cause of the cells rather than skeletal growth. Experiments on plagioclase dissolution and the formation of sieve-textures by Tsuchiyama (1985) found that calcic plagioclase grown in a more mafic melt will react very little when exposed to a more felsic melt due to mixing; significant dissolution is only seen in the sodic crystal population. In addition, the dissolution of sodic plagioclase in these experiments produced fine 'dusty’ sieve-texturing, rather than coarser honeycomb or patchy textures. This may lead toward decompression as the cause of the patchy and honeycombed cores in the Ngauruhoe plagioclase, although as noted by Nelson and Montana (1992) there is the possibility that further magma mixing experiments using a wider range of 
temperatures, pressures and compositions may be able to reproduce such textures, so mixing should not be ruled out entirely.

In water-undersaturated conditions, a decrease in pressure decreases the plagioclase liquidus, allowing resorption to take place (Vance, 1965). Conditions need to be waterundersaturated to form sieved or patchy textures in this way, as decompression of water saturated magmas would crystallise plagioclase as volatiles are exsolved rather than resorbing it (Blundy and Cashman, 2001). Viccaro et al. (2009) observe both patchy zoning and coarse sieve textures in the cores of plagioclase from Mt Etna. They interpret the patchy cores as arising from slow rates of decompression of a waterundersaturated melt, and coarse honeycomb sieving arising due to intermediate rates of decompression between that which results in patchy cores and that which would result in an entirely resorbed or dissolved core. However, isothermal decompression forces the liquid to more calcic compositions (Vance, 1965; Pearce et al. 1993). While this is what causes the resorption to occur, it also means that unless further physical or chemical changes take place, the plagioclase that begins to crystallise as the magma cools would still be relatively calcic. This has been used by some authors to explain unresorbed calcic regions surrounding sieved cores (Coombs et al., 2000), and while it does not pose a problem for explaining sieved textured cores, it does create an issue for explaining patchy cores as occurring by the same process. If a small amount of hot melt containing calcic cores is moved upward into a much more voluminous melt that is in equilibrium with more sodic plagioclase, then perhaps the more sodic chemistry would dominate and crystallise more albitic plagioclase into voids left by the decompressioninduced resorption. However, the zones directly outside the remnants of the calcic core would also be expected to be of more albitic composition. On the contrary, whilst a number of the Ngauruhoe plagioclase contain patches of more sodic material in an otherwise highly calcic core, the clear material surrounding the core which is unaffected by either sieving or patchy texturing is generally of the same or similar anorthite content to the core itself. Oscillatory rim material is of similar anorthite content to the sodic patches, but the rim material does not commence until after a clear calcic region (e.g. Figure 4.10). It may be that the width of such clear regions is largely a sectioning effect, 
and that open channels were nearer to the edge of the calcic area than they appear, allowing dissolution of the inner crystal to take place whilst leaving much of the outer edges intact. Some channels do occur even in what appear to be wide clear calcic regions, as marked in Figure 4.10. Of the options considered, the best explanation for the Ngauruhoe plagioclase cores seems to be the slow to intermediate decompression of a water-undersaturated melt and subsequent transferral into a melt that is in equilibrium with considerably more albitic plagioclase than the original core. 


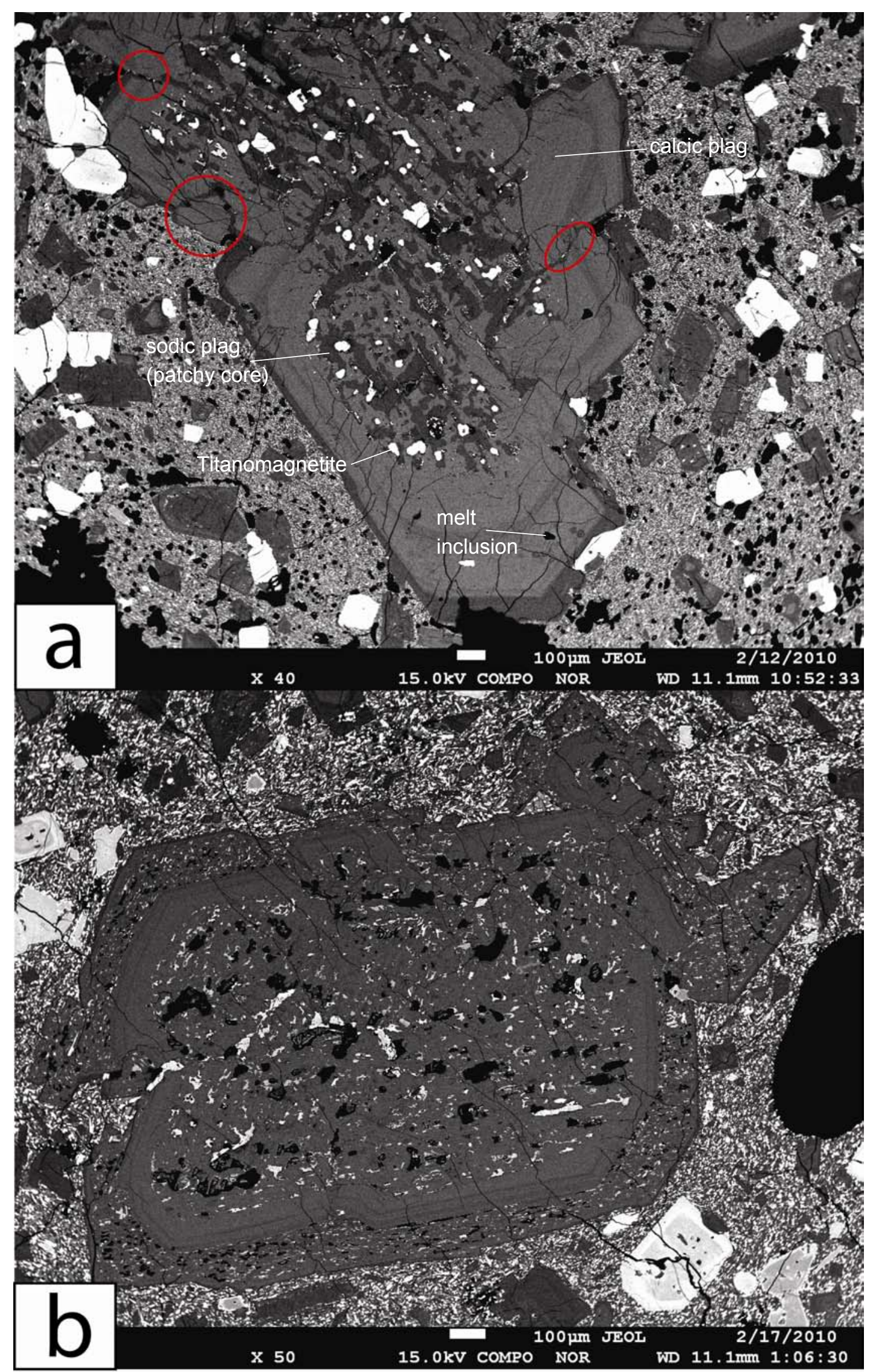

Figure 4.10: Images of plagioclase crystals to illustrate the textures discussed in the text. a: Plagioclase crystal from the 1949 lava flow with a patchy core. Red ellipses highlight 'channels' of sodic composition that link patchy zoning to sodic rim. b: Plagioclase crystal from the $4^{\text {th }}$ June 1954 lava flow showing the difference between coarse (core) versus less-coarse (rim) sieving. 
Sodic regions of plagioclase crystals are often strongly oscillatory zoned, although this varies from crystal-to-crystal (Figure 4.11). Oscillatory zoning can also be observed in a number of calcic cores, to varying degrees (Figure 4.12). Despite earlier suggestions that oscillatory zoning may form as a result of large scale processes such as magma chamber convection (e.g. Bowen, 1928), many current authors prefer explanations relating to crystal growth processes and conditions in the crystal-melt boundary layer (Shore and Fowler, 1996; Ginibre et al., 2002). An alternative suggestion by Blundy et al. (2006) is that oscillatory zoning can be caused by the interplay of decompression, which reduces An, and heating from adjacent crystallising batches of magma, which would increase An. Ginibre et al. (2002) differentiate between fine $(<1-3 \mu \mathrm{m})$, euhedral oscillatory zoning which is suggested to be controlled by kinetic factors, and larger oscillations $(5-10 \mu \mathrm{m})$ that have wavy dissolution surfaces and reflect changes in magma chamber dynamics. Many of the rims of the Ngauruhoe plagioclase are dominated by fine, euhedral, normal oscillatory zoning, but this zoning is periodically interrupted by a sudden return to more calcic chemistry. Where the abrupt change to more calcic zoning occurs, the texture is wavy and embayed (Figure 4.10), indicating that such changes are likely the result of mafic recharge or some other larger scale process. The width of these zones is highly variable. Where a calcic zone is particularly wide, sieving occurs, providing further evidence for large scale changes in magma chemistry or temperature. 


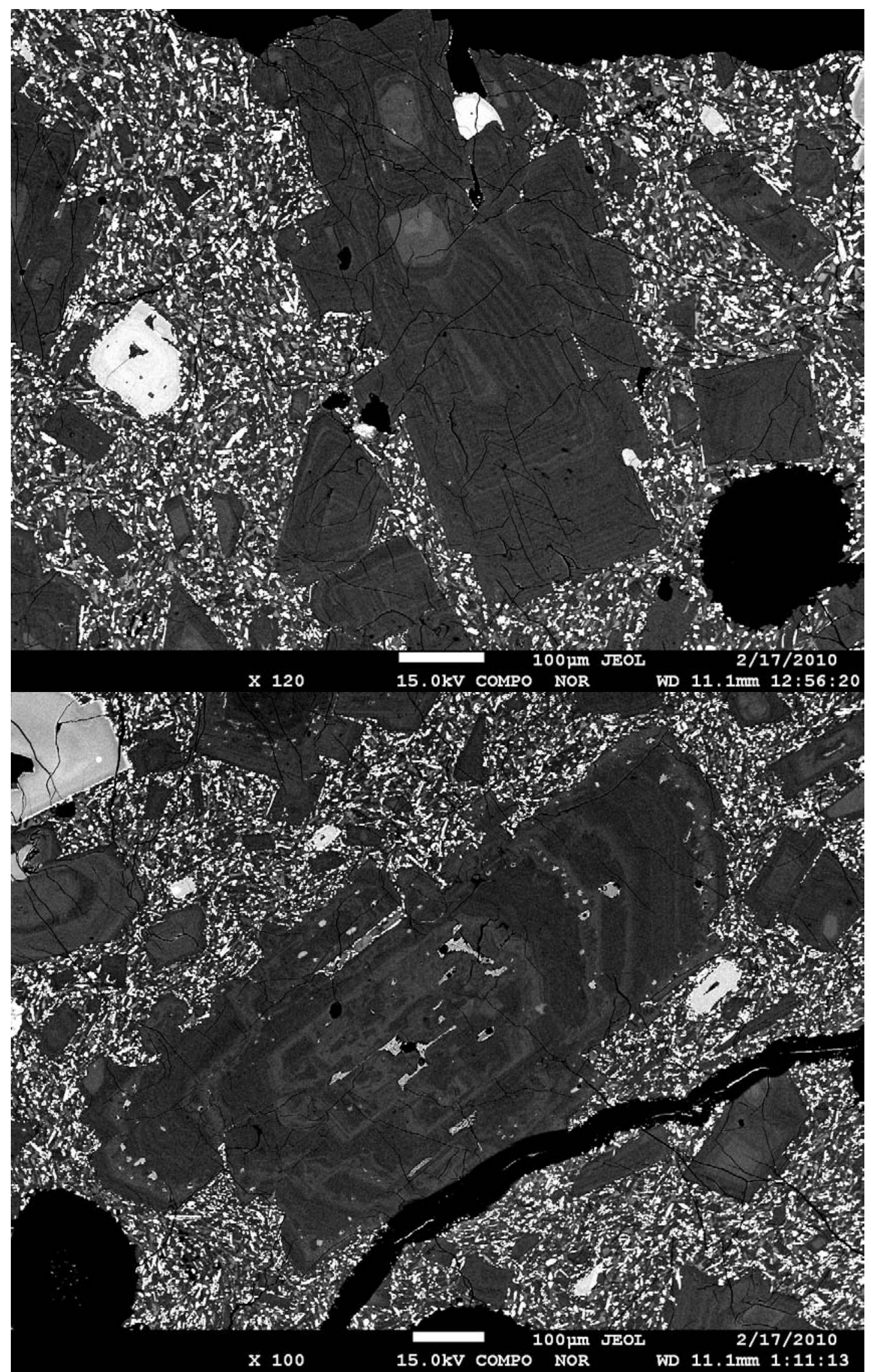

Figure 4.11: Back-scattered electron images showing oscillatory zoning of sodic regions of plagioclase crystals. Top: a plagioclase from the $4^{\text {th }}$ June 1954 lava flow showing abundant finescale oscillatory zoning. Bottom: a plagioclase from the $4^{\text {th }}$ June 1954 lava flow that in addition to some fine scale oscillatory zoning contains several much wider calcic zones, which are wavy and sometimes sieved. 


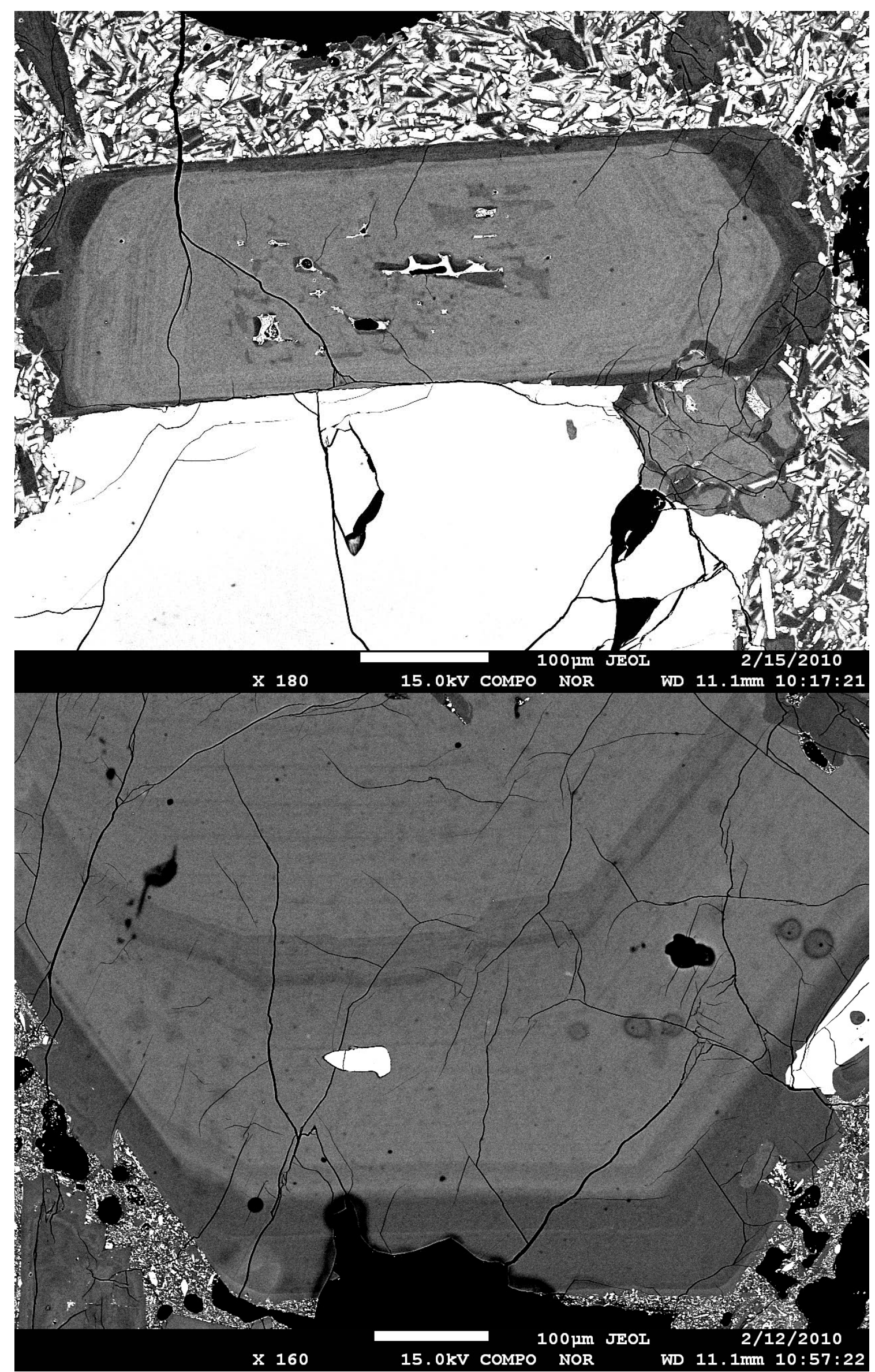

Figure 4.12: Back-scattered electron images of plagioclase crystals in which some oscillatory zoning of the calcic cores is evident. Top: a plagioclase crystal from the $14^{\text {th }}$ July 1954 lava flow. Bottom: an enlarged image of a plagioclase from the 1949 lava flow. 
For the Ngauruhoe plagioclase crystals, sieve-texturing that occurs in a calcic region outside a particularly sodic core or zone can almost always be described as a fine, 'dusty' texture. Such dusty textured regions are usually associated with embayment of the inner sodic region and often long trails of recrystallised calcic material can be seen behind melt inclusions that have developed deep into the sodic zone (e.g. Figure 2.20h). Paired with the evidence from wavy calcic zoning seen in the oscillatory rims of the plagioclase, these dusty regions suggest that the crystals have been repeatedly exposed to melts that are in equilibrium with anorthite rich plagioclase. There is a wide range in the thickness of calcic regions both within and between crystals, possibly suggesting large variations in the lengths of time that the crystals were exposed to higher anorthite conditions, and thus potentially the amount of new material introduced in any mafic recharge event. Dusty texturing also occasionally occurs adjacent to inner zoning that has comparable anorthite content, but where this occurs the inner zoning remains clear and euhedral, indicating that rather than this being the material the dusty zone is resorbing, in such cases the entirety of sodic zoning has been resorbed by more calcic material.

Interpretation of sieved plagioclase textures in this study differs slightly from those of Hobden (1997). Hobden interpreted almost all sieving of Tongariro plagioclase, including that of the cores, as being the result of magma mixing, and only employs the possibility of decompression for those crystals that lack any significant compositional difference between the sieved and unsieved regions. On the contrary, it is noted in the present study that many Ngauruhoe plagioclase crystal cores have a coarser sieving than that seen in other zoning, perhaps suggesting decompression as the cause of sieving for such cores. In addition, most sieving of zoning adjacent to unsieved regions of similar anorthite content is of a finer nature than that observed in crystal cores, and terminates abruptly against the euhedral unaffected inner zone. If resorption due to decompression were the cause, the abrupt termination of the resorption in such a manner is difficult to explain. In this study, such sieved regions have therefore been interpreted as an indication of magma mixing as opposed to decompression, with the sieved region being 
the remnants of a more sodic zone. Sieving has terminated at the more calcic inner zone due to the lack of any significant disequilibrium.

Hora (2003) suggests that the mafic cores may have been sourced from an older basaltic magma system beneath Ngauruhoe, which have later been remobilised by a more felsic melt sloughing these basaltic crystal cores from the wall rock. The evidence he provides for such an interpretation includes: a) calcic cores are generally unzoned, and tens of thousands of years might give time for very fine-scale oscillatory zoning of An-Ab to re-equilibrate, b) high ${ }^{87} \mathrm{Sr} /{ }^{86} \mathrm{Sr}$ ratios of groundmass indicating that the amount of basaltic liquid in any re-charge event must be small relative to the more felsic system, c) some multi-nuclei crystal aggregates and multi-core crystals indicate growth in a crystal-supported mush enivronment, and d) the bimodal nature of the plagioclase An content. The findings from the present study, however, do not necessitate such an origin for the cores, and instead provide some evidence against the idea. Calcic cores frequently $\underline{d o}$ exhibit oscillatory zoning (Figure 4.12), their unzoned appearance may, in many cases, be due to the very restricted range in anorthite content of the oscillations. In addition, the trace element chemistry of mafic cores lies perfectly on the same trends, whether linear or curved, of all other zoning, meaning that any older basaltic system has chemistry almost indistinguishable from later basaltic recharge events. The abundance of mafic cores in Ngauruhoe can be explained by repeated injections of basaltic melt that are then used as a nucleation point for further crystal growth in a shallower, more evolved plumbing system, rather than requiring that any single injection of mafic material is particularly large and would strongly affect the Sr isotopic composition of the felsic system. Evidence for repeated mafic recharge is found in the zoning of pyroxene and plagioclase crystals, and in the range in size and sometimes complete absence of reaction rims on olivine crystals. Rather than requiring a separate, older magmatic system, the bimodality of plagioclase anorthite can be explained by crystal cores from a mafic melt being moved into an already established shallower plumbing system containing melt that has experienced considerably more crystallisation and interaction with the crust, in small enough amounts such that felsic conditions are quickly restored. 


\section{Olivine}

Olivine is a minor but persistent phase in the historical Ngauruhoe lavas, and shows textural evidence of significant disequilibrium with the final melt. It is also the only crystal phase containing inclusions of Cr-spinel, supporting a primitive origin for the crystals. All olivines are anhedral and mantled by an orthopyroxene reaction rim, with the exception of the three most Mg-rich ( $\left.\mathrm{Fo}_{76-77}\right)$ crystals analysed in the 1975 lava flow, which are notable for their lack of any reaction rim or significant re-equilibration to more evolved conditions. A few crystals show evidence of chemical re-equilibration where the olivine has been altered to more Fe-rich chemistry adjacent to melt inclusions and at the crystal edges adjacent to the orthopyroxene reaction rim. This suggests disequilibrium between melt inclusions and the host olivine, and for those crystals that have partially re-equilibrated with surrounding orthopyroxene it indicates that Fe-Mg interdiffusion was not outpaced by olivine dissolution (Coombs and Gardner, 2004). About $40 \%$ of olivines also exhibit vermicular titanomagnetite growth at the crystal edges, forming part of the reaction rim with orthopyroxene. This vermicular titanomagnetite is generally finer adjacent to the olivine and coarser further from the crystal edge. The cores of olivines which contain vermicular titanomagnetite in the reaction rim always have lower $\mathrm{Mg \#}$ than other olivines from the same sample that have a reaction rim of orthopyroxene only. Suggestions as to the cause of orthopyroxene and titanomagnetite symplectitic reaction rims on olivine include oxidation (Goode, 1974; Johnston and Stout, 1984) or the reaction of olivine with a late stage magmatic fluid phase (Carstens, 1957; Gardner and Robins, 1974; Amber and Ashley 1977).

Nitsan (1974) suggested that oxidation of olivine may occur when the crystal is subjected to higher oxygen fugacity, higher temperatures, or lower pressures without the commensurate changes in the other two variables that would be necessary to remain within the stability field of the olivine. So, while the titanomagnetite and orthopyroxene symplectitic textures exhibited by the olivines may indicate a shift to higher oxygen fugacity, they may also or alternatively be the result of heating at lower pressures (e.g. due to mafic recharge at the base), or rapid ascent of the magma whilst still at high temperatures. Thus, although it is not necessarily the cause, there is the possibility that 
the growth of vermicular Fe-Ti oxides from the olivines is the result of the same decompression of a hot mafic melt that may have caused patchy zoning and honeycomb textures in the plagioclase cores. Oxidation of the olivine crystals would produce orthopyroxene that is more Mg rich than the original olivine (Goode, 1974; Johnston and Stout, 1984) as some of the $\mathrm{Fe}^{2+}$ from the olivine is converted into $\mathrm{Fe}^{3+}$ and removed into the titanomagnetite. Unfortunately, the orthopyroxene reaction rims that were measured in this study did not have significant Fe-Ti oxide formation so were unable to provide support for this.

The size and presence of the symplectitic reaction rim and any diffusive re-equilibration varies largely, even within samples. This indicates that the olivines have either had different histories until shortly prior to eruption, or have been introduced to more felsic or oxidising conditions at different times. In about a third of the olivine population examined in this study, the orthopyroxene reaction rim has grown large equant orthopyroxene crystals, and appears to also have acted as a nucleation point for plagioclase crystallisation, giving the appearance of a crystal clot. While it is possible that these could be actual crystal clots that have at some point formed part of a crystal framework against the walls of the shallow magma plumbing system it is highly unlikely: the anhedral olivines are always in the centre and always surrounded by a reaction rim of orthopyroxene, with further plagioclase and orthopyroxene growing out from this. No clinopyroxene is present in the reaction rim, despite being a mafic phase that commences crystallisation at a similar time to plagioclase (discussed in section 4.2.1). Similar textures of orthopyroxene and plagioclase on olivine crystals have been identified at other arc volcanoes, such as Tungurahua Volcano in Ecuador (Samaniego et al., 2011), and are interpreted as being reaction rims. However, there is little explanation as to what causes plagioclase to form part of the reaction rim. 


\subsection{Temporal variability in the magma system}

\subsubsection{Temporal changes in magma chemistry}

Despite changes in whole-rock chemistry that suggest substantial variability throughout the historical eruptions (Hobden et al., 1999, 2002), mineral major and trace element data for the lava flows shows little variability and for most elements samples are indistinguishable from one another. The overall plumbing system and chemistry of the melts involved has therefore remained much the same throughout eruption of the historical lava flows. This suggests that most of the variation in whole-rock chemistry must arise from factors such as the amount of crustal assimilation and/or mafic recharge affecting the final melt just prior to eruption, or the proportion of crystals relative to groundmass, rather than there being any substantial differences in the crystal population. Nevertheless, some differences between the lava flows can be noted. Whilst the 1870 lava flow appears to have interacted with a particularly silicic melt based on clinopyroxene melt inclusions, the modelled groundmass composition presented in Table 4.2 alongside whole-rock $\mathrm{SiO}_{2}, \mathrm{MgO}$ and ${ }^{87} \mathrm{Sr} /{ }^{86} \mathrm{Sr}$ data from Hobden et al (1999, 2002), and groundmass ${ }^{87} \mathrm{Sr} /{ }^{86} \mathrm{Sr}$ data from Hora (2003) all suggest that the final melt may have been the least evolved of the historical eruptions. Conversely, the 1949 lava flow appears to have had the most silicic final melt chemistry; the Mg-rich rims on clinopyroxene crystals are particularly thin, perhaps indicating that mafic recharge prior to eruption was small, and olivine crystals have particularly large reaction rims compared with those observed in the other historical lava flows (Figure 4.13). As with the 1870 lava flows, these observations are reflected in whole-rock major element and isotopic data from Hobden et al. (1999, 2002). There may have been fewer recharge events, more fractional crystallisation and/or more crustal interaction occurring in the final magma chamber prior to eruption of the 1949 lava flow compared with the other historical lava flows. The $14^{\text {th }}$ July 1954 lava flow has a distinct texture towards the rim of some clinopyroxene crystals that is not observed in the lava flows that erupted prior to it (Figure 2.9 e-f). The mafic areas of crystals showing this texture approach core compositions, with Mg\# 85-87. Such high Mg\# zoning that occurs after Fe-rich zoning is not commonly observed in the Ngauruhoe clinopyroxenes. The $14^{\text {th }}$ July- $18^{\text {th }}$ September 1954 lava flows also differ from earlier flows with the presence of crystals 
that are almost entirely of mafic compositions (Mg\# > 80), indicating they may have been brought up in the most recent influx of mafic melt prior to eruption.

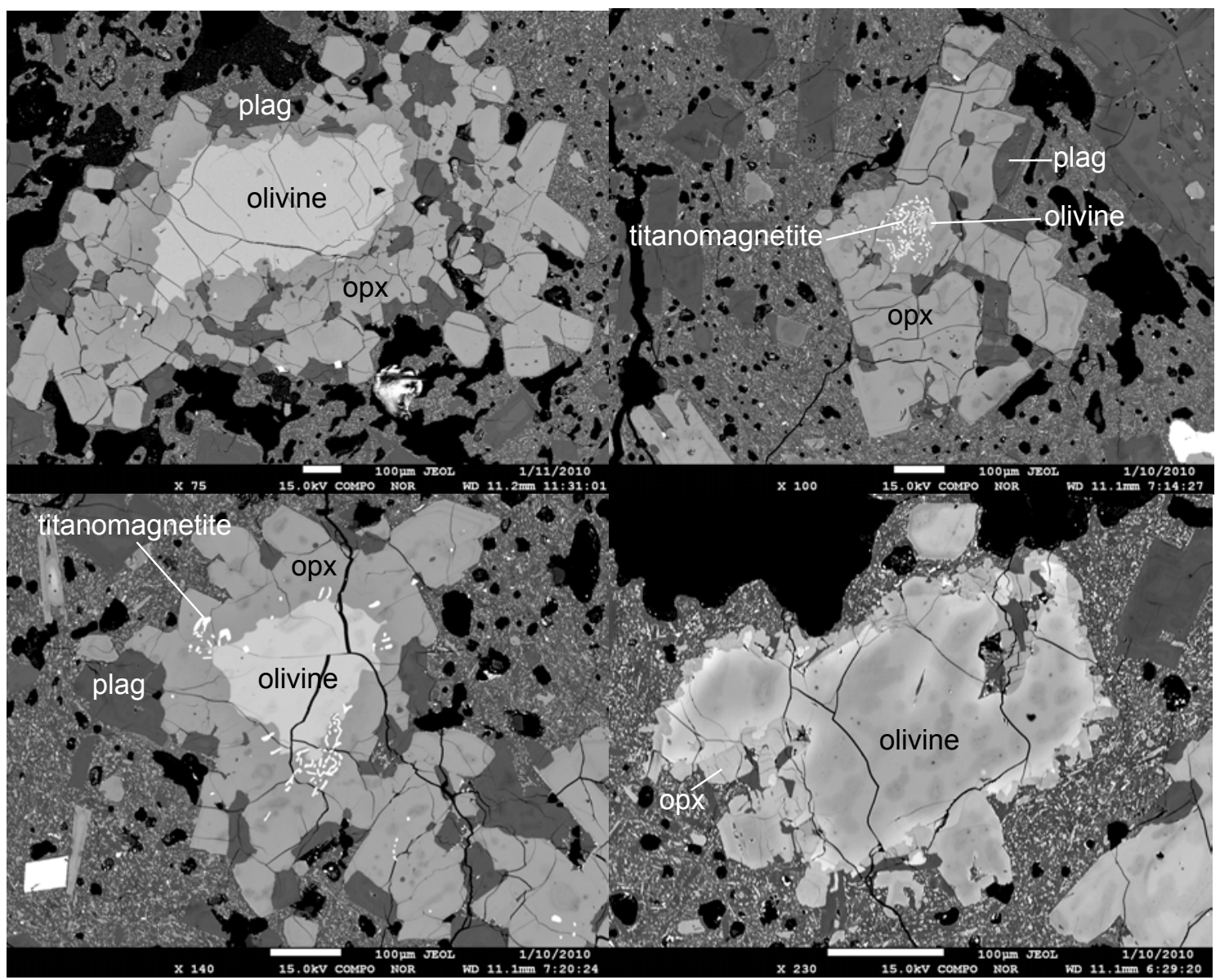

Figure 4.13: BSE images of olivine crystals from the 1949 lava flow showing the presence of particularly large reaction rims. The crystal in the bottom right is the only of the eight crystals in the polished section to have a thin reaction rim, and was also the most Mg-rich crystal (Mg\# 76).

\subsubsection{Temporal information from diffusion modelling}

Almost all clinopyroxene crystals from all samples possess a thin Mg-rich rim that, when modelled, returned timescales suggesting formation only weeks to months prior to eruption (Figure 4.14). Given that both temperature errors and sectioning effects would bias these ages towards longer timescales, it is likely that this represents a maximum timescale, unless oxygen fugacities in the system are significantly lower than that used (e.g. $10^{-15}$ as opposed to $10^{-12.5}$ ), in which case timescales may be up to a factor of $\sim 4$ longer. Where the Mg-rich rims were wide enough to analyse by EPMA they also had increased Cr contents, indicating a change in melt chemistry to more mafic conditions. This would suggest that, regardless of the length of time spent in the plumbing system 
prior to eruption, all historical Ngauruhoe eruptions have been triggered by mafic recharge that probably occurred no more than 1-2 months prior to eruption. Such timescales are similar to other diffusion modelling results obtained for the timing of mafic recharge events at arc volcanoes. For example Martin et al. (2008) suggest a timescale of about a month prior to eruption for the injection of basaltic andesite into dacite at Santorini, Greece, based on olivine diffusion modelling. Morgan et al. (2004) obtained timescales from zero residence (no rim) up 9 yr for Fe-Mg inter-diffusion modelling of clinopyroxene crystals from the Vesuvius 1944 eruption. Both of these studies differ from the present one in that the boundary modelled in those studies was between a more mafic core and more felsic rim.

The Ngauruhoe clinopyroxene crystal populations are dominated by mafic cores. Timescales obtained by diffusion modelling of these mafic cores were found to vary greatly, from $<1$ yr up to $150 \mathrm{yr}$. This may indicate that throughout the historical eruptive period the system has experienced frequent recharge of small amounts of mafic magma, introducing only a few cores to the system during each event. Such a model is consistent with the high frequency (every 2.5 years on average) of ash eruptions observed at Ngauruhoe (Gregg, 1960), and with the textural features of the crystal populations; clinopyroxene rim timescales that suggest a recharge event about a month prior to each eruption, mafic inner zones that indicate further interaction with mafic melt occurring without eruption, and variations in the size of olivine reaction rims within single lava flows. However, the possibility that discrete recharge events are being obscured by the errors associated with diffusion modelling cannot be discounted. Off-centre crystal sections would give artificially longer timescales, and the further offcentre the section is, the longer the timescale obtained from the boundary would be. As such, poorly sectioned crystals might generate a similar continuum of 'timescales'.

Regardless of the frequency of input, 41 of the 45 clinopyroxene core ages obtained are $<50 \mathrm{yr}$, indicating short residence times for magma batches in the crust. Core ages of $<50$ yr would mean that, whilst they may have originated from the same mafic melt that was already stored somewhere in the crust, none of the modelled mafic cores expelled 
in subsequent eruptions were already residing in felsic parts of the plumbing system at the time of the 1870 eruption, nor were they introduced to more felsic melt as part of the recharge that triggered that eruption. If the dacitic melt in which the crystal cores reside following injection into the more evolved chamber is considerably cooler than the final melt temperatures calculated from two-pyroxene geothermometry (Appendix 4), then there is the possibility that core ages may be somewhat longer, but significant cooling seems unlikely given the high levels of magmatic activity that were maintained at Ngauruhoe throughout the entire historical eruption period. However, as mentioned in the case of diffusion modelling ages for the rims and discussed further in Appendix 5, a significantly lower oxygen fugacity than that used for modelling would have the potential to increase the timescales by a factor of $\sim 4$. This effect is more important for the cores than for the rims, as rather than extending ages by 1-2 months it would increase the upper range of core ages from $~ 50$ yr to $200 \mathrm{yr}$. However, even if this were the case, $75 \%$ of the modelled core ages would still be $<100 \mathrm{yr}$ and $65 \%<50 \mathrm{yr}$, meaning that throughout the historical eruptions at Ngauruhoe the majority of crystals have been moved through the system rapidly. 


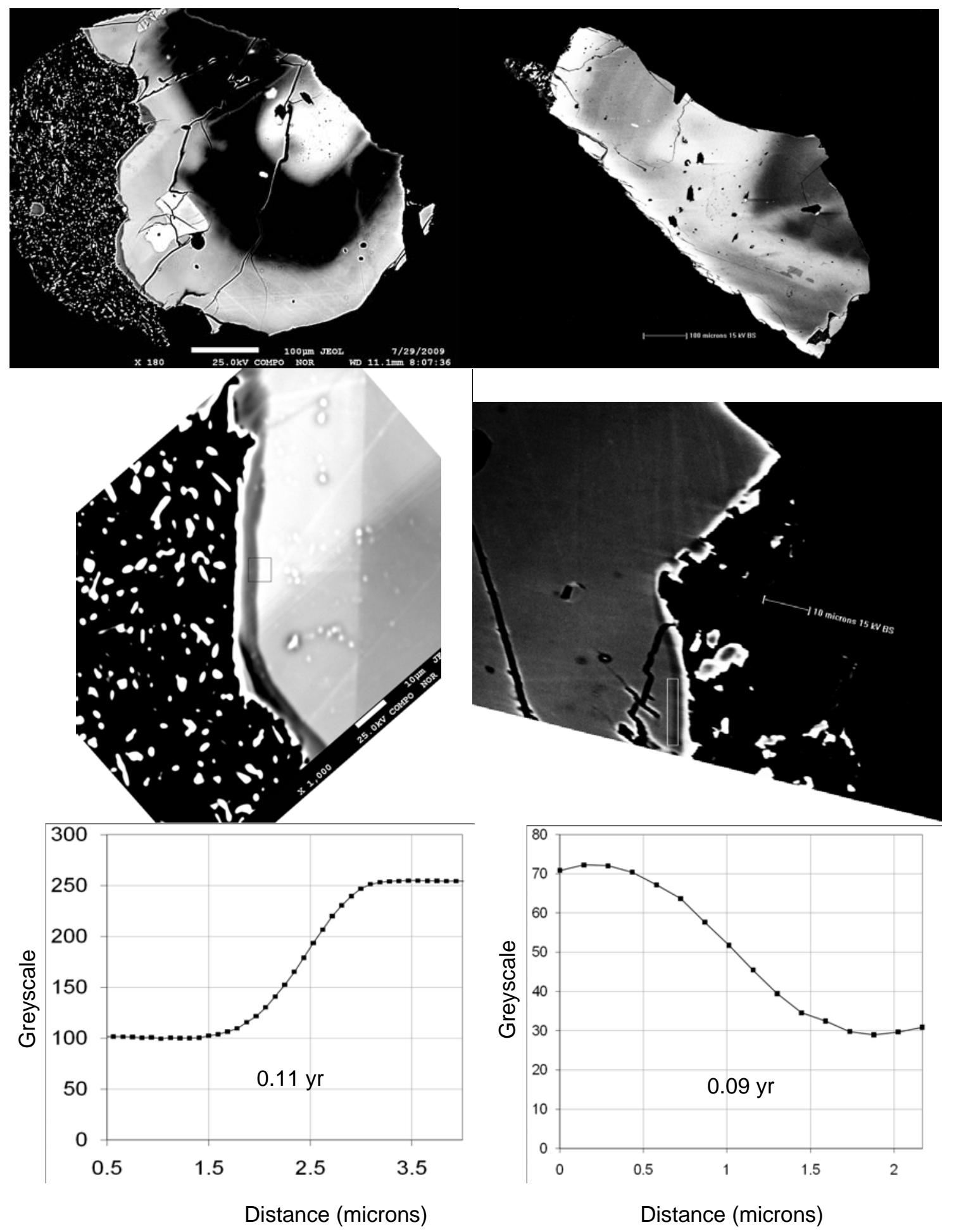

Figure 4.14: BSE images of crystals with thin Mg-rich rims from the $30^{\text {th }}$ June 1954 (left) and 1870 (right) lava flows. Enlarged images showing the rims are given below each crystal, and at the bottom of the figure the diffusion profile from the greyscale across the boundaries is shown, along with the timescale calculated. 


\section{CHAPTER FIVE: CONCLUSIONS}

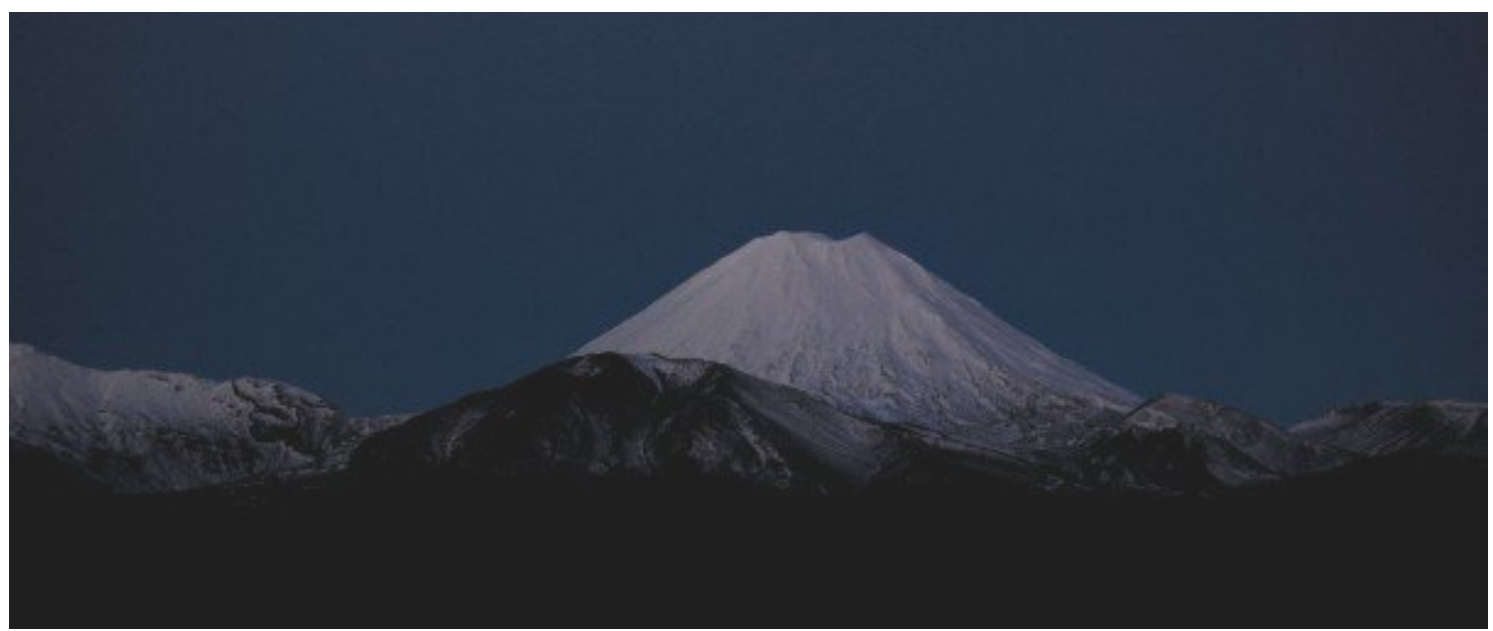

Plate 5: Ngauruhoe at night. Photograph by Rebecca Gordon. 


\subsection{Conclusions}

This thesis has presented a detailed account of the petrology and crystal specific geochemistry of ten historically erupted lava flows from Ngauruhoe volcano, New Zealand. The main conclusions that can be drawn from the study are:

1. The Ngauruhoe magma system is characterised by the repeated recharge of an evolved shallow plumbing system by a mafic magma. Clinopyroxene melt inclusion data suggest that the felsic end member melt in the evolved system is most likely high silica andesite to dacite in composition, which is not in equilibrium with either olivine or quartz. The mafic recharge magma contains olivine, clinopyroxene and plagioclase cores that indicate it was originally basaltic in composition, but it undergoes variable amounts of fractional crystallisation prior to any interaction with the evolved melt.

2. Turnover of the melt in the evolved system is relatively fast with diffusion modelling of mafic clinopyroxene cores suggesting that they reside in the more evolved system for $<50-100 \mathrm{yr}$, and most are in there for considerably shorter times.

3. Compositional bimodality of melts is maintained despite the high frequency of magma recharge/mixing, as evidenced by the bimodality of the clinopyroxene Mg\# and plagioclase anorthite compositions of the mineral population.

4. Both fractional crystallisation and mixing processes are important in generating the diversity of the Ngauruhoe mineral population, with fractional crystallisation occurring in both the mafic and felsic parts of the plumbing system, and mixing between the mafic and felsic end members being a frequent occurrence.

5. Eruptions of lava flows at Ngauruhoe over the historical eruption period have been triggered by repeated mafic magma recharge events that take place weeks to months prior to eruption at most. 


\subsection{Suggestions for future work}

A number of possibilities for future have become evident during the course of this study that are listed below:

1. The use of electron back-scatter diffraction and U-stage (3-dimensional) petrography to establish and correct for crystallographic orientation, enabling modelling of inner crystal zones that are poorly oriented due to the broken nature of crystals returned from the rock-crusher. Further clinopyroxene diffusion modelling work would better constrain the ages of the cores. This might enable the identification of discrete recharge events; for example is it possible to identify cores that were injected in to the system as part of the 1954 eruption recharge later being erupted in the 1975 eruption?

2. Many of the olivine crystals exhibit diffusional re-equilibration with the surrounding orthopyroxene. The diffusion modelling method described in Martin et al. (2008) allows modelling of such crystals, despite the boundary across which diffusion is taking place being one that is between different minerals (orthopyroxene and olivine), and is wavy due to resorption. Modelling of the olivine crystals to determine the length of time they have resided in the new melt would provide an interesting comparison to clinopyroxene crystal core ages.

3. Diffusion modelling of plagioclase and orthopyroxene crystals to compare with results obtained from clinopyroxenes. Does modelling of different crystal phases and different elements in those phases return consistent timescales? If not, what information can this provide on the accuracy and applications of diffusion modelling, the nature of the Ngauruhoe plumbing system, and/or differences in the magmatic processes and events that are recorded by different crystal phases?

4. A companion and comparative study of the pre-historical flows to assess if they exhibit differences in magmatic processes and timescales, potentially related to the larger eruptive volumes and higher crystallinities of the pre-historical flows. 


\section{REFERENCES}

Abramoff, M.D., Magelhaes, P.J., Ram, S.J. (2004). Image Processing with ImageJ. Biophotonics International, 11(7), 36-42

Allan, A.S.R. (2008). An elementary and isotopic investigation of Quaternary Silicic Taupo Zone tephras from ODP Site 1123: chronostratigraphic and petrogenetic applications. MSc thesis, Victoria University of Wellington, Wellington, New Zealand.

Amber E.P. \& Ashley P.M. (1977). Vernicular orthopyroxene-magnetite symplectites from the Wateranga layered mafic intrusion, Queensland, Australia. Lithos, 10, 163-172

Andersen, D.J. \& Lindsley, D.H., 1988. Internally consistent solution models for FeMg-Mn-Ti oxides: Fe-Ti oxides. American Mineralogist, 73(7-8), 714-726

Annen, C., Blundy, J.D. \& Sparks, R.S.J. (2006). The Genesis of Intermediate and Silicic Magmas in Deep Crustal Hot Zones. Journal of Petrology, 47(3), 505539

Azough, F. \& Freer, R. (2000). Iron Diffusion in Single-Crystal Diopside. Physics and Chemistry of Minerals, 27, 732-740

Battey, M.H. (1949). The Recent Eruption of Ngauruhoe. Records of the Auckland Institute and Museum, 3, 387-395

Beattie, P. (1993). Olivine-melt and orthopyroxene-melt equilibria. Contributions to Mineralogy and Petrology, 115, 103-111

Beckinsale R.D. \& Mitchell A.H.G. (1981). Ore deposits associated with subduction: in Tarling, D.H. (ed.)(1981): Economic geology and geotectonics. Blackwell Scientific Pubications, Oxford pp.213

van Bergen, M.J. \& Barton, M. (1984). Complex interaction of aluminous metasedimentary xenoliths and siliceous magma; an example from Mt. Amiata (Central Italy). Contributions to Mineralogy and Petrology, 86, 374-385

Berlo, K., Blundy, J., Turner, S., Hawkesworth, C. (2007). Textural and chemical variation in plagioclase phenocrysts from the 1980 eruptions of Mount St. Helens, USA. Contributions to Mineralogy and Petrology, 154, 291-308

Bindeman, I.N., Davis, A.M \& Drake, M.J. (1998). Ion microprobe study of plagioclase-basalt partition experiments at natural concentration levels of trace elements. Geochimica et Cosmochimica Acta, 62(7), 1175-1193

Blundy, J. \& Cashman, K. V. (2001). Magma ascent and crystallisation at Mount St Helens, 1980-1986. Contributions to Mineralogy and Petrology 140, 631-650.

Blundy, J. \& Wood, B. (1991). Predictions of crystal-melt partition coefficients from elastic moduli. Nature, 372, pp. 452-454 
Blundy, J., Cashman, K. \& Humphreys, M. (2006). Magma heating by decompressiondriven crystallization beneath andesite volcanoes. Nature, 443, 76-80

Bowen, N.L., (1928). The evolution of the igneous rocks. Princeton, New Jersey, Princeton University Press,

Brey, G.P. \& Köhler, T. (1990). Geothermobarometry in four-phase lherzolites II. New thermobarometers, and practical assessment of existing thermobarometers. Journal of Petrolology, 31, 1353-1378

Brown, S.J.A., Wilson, C.J.N., Cole J.W., Wooden, J. (1998). The Whakamaru group ignimbrites, Taupo Volcanic Zone, NewZealand: evidence for reverse tapping of a zoned silicic magmatic system. Journal of Volcanology and Geothermal Research, 84, 1-37

Browne, P.R.L., Graham, I.J., Parker, R.J., \& Wood, C.P. (1992). Subsurface andesite lavas and plutonic rocks in the Rotokawa and Ngatamariki geothermal systems, Taupo Volcanic Zone, New Zealand. Journal of Volcanology and Geothermal Research, 51, 199-215

Carmichael, I.S.E., Turner, F.J. \& Verhoogen, J. (1974). Igneous Petrology. McGrawHill Inc., US

Carstens, H. (1957). Investigations of titaniferous iron ore deposits. Part I. Gabbros and associated titaniferous iron ore in the west-Norwegian gneisses. Kongelige Norske Videnskabers Selskab Skrifter, 3, 1-67

Chakraborty, S. (1997). Rates and mechanisms of Fe-Mg interdiffusion in olivine at $980^{\circ} \mathrm{C}-1300^{\circ} \mathrm{C}$. Journal of Geophysical Research, 102, 12317-12331

Chakraborty, S. (2008). Diffusion in Solid Silicates: A Tool to Track Timescales of Processes Comes of Age. Annual Review of Earth and Planetary Sciences, 36, 153-190

Cloud, P.E. (1951). The 1949 Eruption of Ngauruhoe. The Scientific Monthly, 72(4), 241-251

Cole, J.W. (1978). Andesites of the Tongariro Volcanic Centre, North Island, New Zealand. Journal of Volcanology and Geothermal Research, 3, 121-153

Cole, J.W. (1990). Structural control and origin of volcanism in the Taupo volcanic zone, New Zealand. Bulletin of Volcanology, 52, 445-459

Cole, J.W., Graham I.J., Hackett W.R., Houghton B.F. (1986) Volcanology and petrology of the Quaternary composite volcanoes of Tongariro volcanic centre, Taupo volcanic zone. In: Smith IEM (ed) Late Cenozoic Volcanism in New Zealand. Royal Society of New Zealand Bulletin, 23, pp. 224-250 
Cole, J.W., Gamble, J.A., Burt, R.M., Carroll, L.D. and Shelley, D. (2001). Mixing and mingling in the evolution of andesite-dacite magmas; evidence from comagmatic plutonic enclaves, Taupo Volcanic Zone, New Zealand. Lithos, 59, 25-46

Costa, F., Dohmen, R., \& Chakraborty, S. (2008). Time Scales of Magmatic Processes from Modeling the Zoning Patterns of Crystals. Reviews in Mineralogy and Geochemistry, 69, 545-594

Costa F. \& Morgan D. (2010). Time Constraints from Chemical Equilibration in Magmatic Crystals. In: Dossetto, A., Turner, S. \& Van-Orman, J. (eds.). Timescales of Magmatic Processes. Blackwell Publishing Ltd., Sussex, pp. 125159

Condomines, M., Gauthier, P-J., \& Sigmarsson, O. (2003). Timescales of Magma Chamber Processes and Dating of Young Volcanic Rocks. Reviews in Mineralogy and Geochemistry, 52, 125-174

Coombs, M.L. \& Gardner, J.E. (2004). Reaction rim growth on olivine in silicic melts: Implications for magma mixing. American Minerologist, 89, 748-759

Coombs, M.L., Eichelberger, J.C., Rutherford, M.J. (2000). Magma storage and mixing conditions for the 1953-1974 eruptions of Southwest Trident volcano, Katmai National Park, Alaska. Contributions to Mineralogy and Petrology,140, 99-118

Crank, J. (1975). The Mathematics of Diffusion, 2nd ed. Clarendon Press, Oxford.

Davidson, P.M. \& Lindsley, D.H. (1989). Thermodynamic analysis of pyroxene-olivine-quartz equilibria in the system $\mathrm{CaO}-\mathrm{MgO}-\mathrm{FeO}-\mathrm{SiO}$. American Mineralogist, 74, 18-30

Davidson, J., Tepley III, F., Palacz, Z. \& Meffan-Main, S. (2001). Magma recharge, contamination and residence times revealed by in situ laser ablation isotopic analysis of feldspar in volcanic rocks. Earth and Planetary Science Letters, 184, 427-442

Dimanov, A. \& Sautter, V. (2000). “Average” interdiffusion of (Fe,Mn)-Mg in natural diopside. European Journal of Mineralogy, 12, 749-760

Dimanov, A., Jaoul, O., \& Sautter, V. (1996). Calcium self-diffusion in natural diopside single crystals. Geochimica et Cosmochimica Acta, 60(21), 4095- 4106

Dimanov, A. \& Wiedenbeck, W. (2006). (Fe,Mn)-Mg interdiffusion in natural diopside: effect of pO2. European Journal of Mineralology, 18, 705-718

Dohmen, R., Becker, H-W., \& Chakraborty, S. (2007). Fe-Mg diffusion in olivine I: experimental determination between 700 and $1,200^{\circ} \mathrm{C}$ as a function of composition, crystal orientation and oxygen fugacity. Physics and Chemistry of Minerals, 34, 389-407 
Donoghue, S.L., Neall, V.E., \& Palmer, A.S. (1995). Stratigraphy and chronology of late Quaternary andesitic tephra deposits, Tongariro Volcanic Centre, New Zealand. Journal of The Royal Society of New Zealand, 25(2), 115-206

Dungan, M.A. \& Rhodes, J.M. (1978). Residual Glasses and Melt Inclusions in Basalts from DSDP Legs 45 and 46: Evidence for Magma Mixing. Contributions to Mineralogy and Petrology, 67, 417-431

Eggins, S.M., Kinsley, L.P.J., \& Shelley, J.M.G. (1998). Deposition and element fractionation processes during atmospheric pressure laser sampling for analysis by ICP-MS. Applied Surface Science, 127-129, 278-286

England, P., Engdahl, R. \& Thatcher, W. (2004). Systematic variation in the depths of slabs beneath arc volcanoes. Geophysical Journal International, 156, 377- 408

Fergusson, G.J. \& Rafter, T.A. (1959). New Zealand ${ }^{14} \mathrm{C}$ age measurements. New Zealand Journal of Geology and Geophysics, 2, 208-241

Freer, R. and Hauptman, Z. (1978). An experimental study of magnetitetitanomagnetite interdiffusion. Physics othe Earth and Planetary Interiors, 16 223-23 1

Gamble J.A., Smith, I.E.M., Graham, I.J., Kokelaar, B.P., Cole, J.W., Houghton B.F. and Wilson, C.J.N. (1990). The petrology, phase relations and tectonic setting of basalts from the Taupo Volcanic Zone, New Zealand and the Kermadec Island Arc - Havre Trough, SW Pacific. Journal of Volcanology and Geothermal Research, 43, 235-270

Gamble, J.A., Smith, I.E.M., McCulloch, M.T., Graham, I.J., \& Kokelaar, B.P. (1993). The geochemistry and petrogenesis of basalts from the Taupo Volcanic Zone and Kermadec Island Arc, S.W. Pacific. Journal of Volcanology and Geothermal Research, 54, 265-290

Gardner P.M., Robins B. (1974). The olivine-plagioclase reaction: Evidence from the Seiland petrographic province, northern Norway. Contributions to Mineralogy and Petrology 44, 149-156

Giletti, B.J. \& Shanahan, T.M. (1997). Alkali diffusion in plagioclase feldspar. Chemical Geology, 139, 3-20

Gill, J.B. (1981). Orogenic Andesites and Plate Tectonics. Springer Verlag, Berlin.

Ginibre, C, Kronz, A \& Wörner, G. (2002). High-resolution quantitative imaging of plagioclase composition using accumulated backscattered electron images: new constraints on oscillatory zoning. Contributions to Mineralogy and Petrology, 142, 436-448

Ginibre, C., Wörner, G., \& Kronz, A. (2007). Crystal Zoning as an Archive for Magma Evolution. Elements, 3, 261-266

Goode, A.D.T. (1974) Oxidation of natural olivines. Nature, 248, 500-501 
Graham, I.J., Cole, J.W., Gamble, J.A., Briggs, R.M., \& Smith, I.E.M. (1995). Petrology and petrogenesis of volcanic rocks from the Taupo Volcanic Zone: A Review. Journal of Volcanology and Geothermal Research, 68, 59-88

Gregg, D.R, (1956). Eruption of Ngauruhoe 1954-1955. New Zealand Journal of Science and Technology, B37, 675-688

Gregg, D.R, (1960). The Geology of Tongariro Subdivision. New Zealand Geological Survey Bulletin 40.

Grove, T.L. \& Donnelly-Nolan, J.M. (1986). The evolution of young silicic lavas at Medicine Lake Volcano, California: Implications for the origin of compositional gaps in calc-alkaline series lavas. Contributions to Mineralogy and Petrology, 92, 281-302

Günther, D. \& Heinrich, C.A. (1999). Enhanced sensitivity in laser ablation-ICP mass spectrometry using helium-argon mixtures as aerosol carrier. Journal of Analytical Atomic Spectrometry, 14, 1363-1368

Harrison, A.J. \& White, R.S. (2004). Crustal structure of the Taupo Volcanic Zone, New Zealand: Stretching and igneous intrusion. Geophysical Research Letters, 31, L13615, doi:10.1029/2004GL019885

Harrison, A.J. \& White, R.S. (2006). Lithospheric structure of an active backarc basin: the Taupo Volcanic Zone, New Zealand. Geophysical Journal International, 167, 968-990

Hector, J.D. (1870). Eruption of the volcano Tongariro, New Zealand. Nature, 2, 477479

Heilprin, A. (1903). Mont Pelée and the Tragedy of Martinique. J.R. Lippincott, Philadelphia

Hobden, B.J. (1997). Modelling magmatic trends in time and space: eruptive and magmatic history of Tongariro volcanic complex, New Zealand. PhD thesis, University of Canterbury, Christchurch, New Zealand

Hobden, B.J., Houghton, B.F., Lanphere, M.A., \& Nairn, I.A. (1996). Growth of the Tongariro volcanic complex: new evidence from K-Ar age determinations. New Zealand Journal of Geology and Geophysics, 39, 151-154

Hobden, B.J., Houghton, B.F., Davidson, J.P. \& Weaver, S.D. (1999). Small and shortlived magma batches at composite volcanoes: time windows at Tongariro volcano, New Zealand.

Hobden, B.J., Houghton, B.F. \& Nairn, I.A. (2002). Growth of a young, frequently active composite cone: Ngauruhoe volcano, New Zealand. Bulletin of Volcanology, 64, 392-409

Hora J.M. (2003). Magmatic Differentiation Processes at Ngauruhoe Volcano, New Zealand: Constraints from Chemical, Isotopic and Textural Analysis of 
Plagioclase Crystal Zoning. MSc thesis, University of California, Los Angeles, USA.

Houghton, B.F., Wilson, C.J.N., McWilliams, M.O., Lanphere, M.A., Weaver, S.D., Briggs, R.M. \& Pringle, M.S. (1995). Chronology and dynamics of a large silicic magmatic system: Central Taupo Volcanic Zone, New Zealand. Geology, 23(1), 13-16

Jaoul \& Raterron (1994). High-temperature deformation of diopside crystal: 3, Influence of $\mathrm{pO}_{2}$ and $\mathrm{SiO}_{2}$ precipitation. Journal of Geophysical Research, 99(5), 9423

Jarosewich, E., Nelen, J.A., Norberg, J.A., 1979. Electron microprobe reference samples for mineral analysis. Smithsonian Contributions to the Earth Sciences 22, 68-72.

Jerram, D.A. \& Martin, V.M. (2008). Understanding crystal populations and their significance through the magma plumbing system. Geological Society, London, Special Publications, 304, 133-148

Johnston, A.D. and Stout, J.H., (1984). Development of orthopyroxene-Fe/Mg ferrite symplectites by continuous olivine oxidation, Contributions to Mineralogy and Petrology, 88, 196-202

Kawamoto, T. (1992). Dusty and honeycomb plagioclase: indicators of processes in the Uchino stratified magma chamber, Izu Peninsula, Japan. Journal of Volcanology and Geothermal Research, 49, 191-208

Kerrick, D.M. \& Connolly, J.A.D (2001). Metamorphic devolatilization of subducted oceanic metabasalts: implications for seismicity, arc magmatism and volatile recycling. Earth and Planetary Science Letters, 189, 19-29

Kuo L.C. \& Kirkpatrick R.J. (1982). Pre-eruption history of phyric basalts from DSDP Legs 45 and 46: evidence from morphology and zoning patterns in plagioclase, Contributions to Mineralogy. Petrology, 79, pp. 13-27.

Longerich, H.P., Jackson, S.E., Günther, D. (1996). Laser Ablation Inductively Coupled Plasma Mass Spectrometric Transient Signal Data Acquisition and Analyte Concentration Calculation. Journal of Analytical Atomic Spectrometry, 11, pp. 899-904

Lofgren, G.E. (1980). Experimental studies on the dynamic crystallization of silicate melts. In: R.B. Hargraves, (ed.), Physics of Magmatic Processes, Princeton Univ. Press, pp. 487-551.

Lowenstern, J.B. (2003). Melt Inclusions Come of Age: Volatiles, Volcanoes, and Sorby's Legacy. In: B. De Vivo and R.J. Bodnar (eds.). Melt Inclusions in Volcanic Systems: Methods, Applications and Problems. Developments in Volcanology 5, Elsevier Press, Amsterdam, pp. 1-22

Lube,G., Cronin, S.J., Platz, T., Freundt, A., Procter, J.N., Henderson, C., \& Sheridan, M.F. (2007). Flow and deposition of pyroclastic granular flows: A type example 
from the 1975 Ngauruhoe eruption, New Zealand. Journal of Volcanology and Geothermal Research, 161, 165-186

Martin,V.M., Morgan, D.J., Jerram, D.A., Caddick, M.J., Prior, D.J. \& Davidson, J.P. (2008). Bang! Month-scale eruption triggering at Santorini Volcano. Science, 321,1178

McCulloch, M.T. and Gamble, J.A. (1991). Geochemical and geodynamical constraints on subduction zone magmatism. Earth and Planetary Science Letters, 102, 358374

Mercier, J-C.C., Benoit, V. \& Girardeau, J. (1984). Equilibrium state of diopsidebearing harzburgites from ophiolites: geobarometric and geodynamic implications. Contributions to Mineralogy and Petrology, 85, 391-403

Miyashiro, A. (1974). Volcanic rock series in island arcs and active continental margins. American Journal of Science, 274, 321-355

Möbis, A., Cronin, S.J., Lube, G., Neall, V.E., \& Németh, K. (2008). Fingerprinting of volcanic glasses reveals the volcanic history of Ngauruhoe Volcano, New Zealand. Geological Society of New Zealand Miscellaneous Publication 124A, 202

Morgan, D.J. \& Blake, S. (2006). Magmatic residence times of zoned phenocrysts: introduction and application of the binary element diffusion modelling (BEDM) technique. Contributions to Mineralogy and Petrology, 151, 58-70

Morgan, D.J., Blake, S., Rogers, N.W., DeVivo, B., Roland, G., MacDonald, R., \& Hawkesworth, C.J. (2004). Time scales of crystal residence and magma chamber volume from modelling of diffusion profiles in phenocrysts: Vesuvius 1944. Earth and Planetary Science Letters, 222, 933- 946

Mortimer, N. (1994). Origin of the Torlesse Terrane and Coeval Rocks, North Island, New Zealand. International Geology Review, 36, 891-910

Murphy, J.B. (2007). Arc Magmatism II: Geochemical and Isotopic Characteristics. Geoscience Canada, 34(1), 7-35

Nairn, I.A. \& Self, S. (1978). Explosive eruptions and pyroclastic avalanches from Ngauruhoe in February 1975. Journal of Volcanology and Geothermal Research, 3, 39-60

Nelson, S.T. \& Montana, A. (1992). Sieve-textured plagioclase in volcanic rocks produced by rapid decompression. American Mineralogist, 77, 1242-1249

Nickel, K.G. (1989). Garnet-pyroxene equilibria in the system SMACCR $\left(\mathrm{SiO}_{2}-\mathrm{MgO}-\right.$ $\left.\mathrm{Al}_{2} \mathrm{O}_{3}-\mathrm{CaO}-\mathrm{Cr}_{2} \mathrm{O}_{3}\right)$ : the Cr-geobarometer. In: Kimberlites and Related Rocks. Proceedings of the Fourth International Kimberlite Conference, Volume 2, Their Mantle/Crust Setting, Diamond and Diamond Exploration. Geological Society of Australia Special Publication, 14, 901-912 
Nickel, K.G. \& Brey, G.P. (1984). Subsolidus orthopyroxene-clinopyroxene systematics in the system $\mathrm{CaO}-\mathrm{MgO}-\mathrm{SiO}_{2}$ to $60 \mathrm{~kb}$ : a reevaluation of the regular solution model. Contributions to Mineralogy and Petrology, 87, 35-42

Nickel, K.G., Brey, G.P., \& Kogarko, L. (1985). Orthopyroxene-clinopyroxene equilibria in the system $\mathrm{CaO}-\mathrm{MgO}-\mathrm{A}_{2} \mathrm{O}_{3}-\mathrm{SiO}_{2}$ (CMAS): new experimental results and implications for two-pyroxene thermometry. Contributions to Mineralogy and Petrology, 91, 44-53

Nicol, A. \& Wallace, L.M. (2007). Temporal stability of deformation rates: Comparison of geological and geodetic observations, Hikurangi subduction margin, New Zealand. Earth and Planetary Science Letters, 258, 397-413

Nimis, P. \& Taylor, W.R. (2000). Single clinopyroxene thermobarometry for garnet peridotites. Part 1 Calibration and testing of a Cr-in-cpx barometer and an enstatite-in-cpx thermometer. Contributions to Mineralogy and Petrology, 139, 541-554

Nitsan U. (1974). Stability of olivine with respect to oxidation and reduction. Journal of Geophysical Research, 79, 706-711

Onsager, L. (1945). Theories and problems of liquid diffusion. Annals of the New York Academy of Sciences, 46, 241-265

Pearce, T. H. (1993). Recent work on oscillatory zoning in plagioclase. In: Parsons, I. (ed.) Feldspars and their Reactions. Dordrecht: Kluwer Academic, pp. 313-349.

Pearce, N.J.G., Westgate, J.A., \& Perkins, W.T. (1996). Developments in the analysis of volcanic glass shards by laser ablation ICP-MS: Quantitative and single internal standard-multi-element methods. Quaternary International 34-36, 213-227.

Philpotts, A.R. (1990). Principles of Igneous and Metamorphic Petrology. Prentice Hall, New Jersey.

Portnyagin, M., Almeev, R., Matveev, S. \& Holtz, F. (2008). Experimental evidence for rapid water exchange between melt inclusions in olivine and host magma. Earth and Planetary Science Letters, 272, 541-552

Putirka, K. (2005). Igneous thermometers and barometers based on plagioclase + liquid equilibria: tests of some existing models and new calibrations. American Mineralologist, 90, 336-346

Putirka, K.D. (2008). Thermometers and Barometers for Volcanic Systems. Reviews in Mineralogy and Geochemistry, 69, 61-120

Putirka, K., Johnson, M., Kinzler, R., Longhi, J., \& Walker, D. (1996). Thermobarometry of mafic igneous rocks based on clinopyroxene-liquid equilibria, 0-30 kbar. Contributions to Mineralogy and Petrology, 123, 92-108

Putirka, K.D., Mikaelian, H., Ryerson, F., \& Shaw, H. (2003). New clinopyroxeneliquid thermobarometers for mafic, evolved, and volatile-bearing lava 
compositions, with applications to lavas from Tibet and the Snake River Plain, Idaho. American Mineralogist, 88, 1542-1554

Reubi, O. \& Blundy, J. (2009). A dearth of intermediate melts at subduction zone volcanoes and the petrogenesis of arc andesites. Nature, 461, 1269-1273

Roser B. P. and Korsch, R. J. (1999). Geochemical characterization, evolution and source of a Mesozoic accretionary wedge: the Torlesse terrane, New Zealand. Geological Magazine, 136 (5), 493-512

Rowland, J.V. \& Sibson, R.H. (2001). Extensional fault kinematics within the Taupo Volcanic Zone, New Zealand: soft-linked segmentation of a continental rift system. New Zealand Journal of Geology and Geophysics, 44, 271-283

Rowlands, D.P, White, R.S. \& Haines, A.J. (2005). Seismic tomography of the Tongariro Volcanic Centre, New Zealand. Geophysical Journal International 163, 1180-1194

Ruprecht \& Wörner, G. (2007). Variable regimes in magma systems documented in plagioclase zoning patterns: El Misti stratovolcano and Andahua monogenetic cones. Journal of Volcanology and Geothermal Research, 165, 142-162

Samaniego, P., Le Pennec, J., Robin, C., Hidalgo, S. (2011). Petrological analysis of the pre-eruptive magmatic process prior to the 2006 explosive eruptions at Tungurahua volcano (Ecuador). Journal of Volcanology and Geothermal Research, 199, 69-84

Saunders, K. E., Morgan, D. J., Baker J. A., and Wysoczanski, R. J. (2010). The Magmatic Evolution of the Whakamaru Supereruption, New Zealand, Constrained by a Microanalytical Study of Plagioclase and Quartz. Journal of Petrology, 51(12), 2465-2488

Schmidt, M.W. \& Poli, S. (1998). Experimentally based water budgets for dehydrating slabs and consequences for arc magma generation. Earth and Planetary Science Letters, 163, 361-379

Sen, G. (1985). Experimental determination of pyroxene compositions in the system CaO-MgO- $\mathrm{Al}_{2} \mathrm{O}_{3}-\mathrm{SiO}_{2}$ at $900-1200^{\circ} \mathrm{C}$ and $10-15$ kbar using $\mathrm{PbO}$ and $\mathrm{H}_{2} \mathrm{O}$ fluxes. American Mineralogist, 70, 678-695

Shore, M. \& Fowler, A.D. (1996). Oscillatory zoning in minerals: a common phenomenon. The Canadian Mineralogist, 34, 1111-1126

Sibson, R.H. \& Rowland, J.V. (2003). Stress, fluid pressure and structural permeability in seismogenic crust, North Island, New Zealand. Geophysical Journal International, 154, 584-594

Smith, V.C., Shane, P. and Nairn, I.A. (2004). Reactivation of a rhyolitic magma body by new rhyolitic intrusion before the 15.8 ka Rotorua eruptive episode: implications for magma storage in the Okataina Volcanic Centre, New Zealand. Journal of the Geological Society, London, 161, 757-772 
Sneeringer, M., Hart, S.R., \& Shimizu, N. (1984). Strontium and samarium diffusion in diopside. Geochimica et Cosmochimica Acta, 48, 1589-1608

Spinks, K.D., Acocella, V., Cole, J.W., \& Bassett, K.N. (2005). Structural control of volcanism and caldera development in the transtensional Taupo Volcanic Zone, New Zealand. Journal of Volcanology and Geothermal Research, 144, 7- 22

Steiner, A. (1958). Petrogenetic implications of the 1954 Ngauruhoe lava and its xenoliths. New Zealand Journal of Geology and Geophysics, 1, 325-363

Stormer, J.C. (1983). The effects of recalculation on estimates of temperature and oxygen fugacity from analyses of multicomponent iron-titanium oxides. American Mineralogist, 68, pp. 586-594

Stratford WR, Stern TA (2004) Strong seismic reflections and melts in the mantle of a continental back-arc basin. Geophysical Research Letters, 31, L06622

Stratford, W.R. \& Stern, T.A. (2006). Crust and upper mantle structure of a continental backarc: central North Island, New Zealand. Geophysical Journal International, $166,469-484$

Streck, M.J. (2008). Mineral textures and Zoning as evidence for Open System Processes. Reviews in Mineralogy \& Geochemistry, 69, 595-622

Sun, S.-s. \& McDonough, W.F. (1989). Chemical and isotopic systematics of oceanic basalts: implications for mantle composition and processes. Geological Society, London, Special Publications, 42, pp. 313-345

Sutton, A.N., Blake, S. and Wilson, C.J.N. (1995). An outline geochemistry of rhyolite eruptives from Taupo volcanic centre, New Zealand. Journal of Volcanology and Geothermal Research, 68,153-175

Sutton, A.N., Blake, S., Wilson, C.J.N. and Charlier, B.L.A. (2000). Late Quaternary evolution of a hyperactive rhyolite magmatic system: Taupo volcanic centre, New Zealand. Journal of the Geological Society, London, 157, 537-552

Syracuse, E.M. \& Abers, G.A. (2006). Global compilation of variations in slab depth beneath arc volcanoes and implications. Geochemistry Geophysics Geosystems, 7(5), Q05017

Symons, G.J. (1888). The Eruption of Krakatoa and Subsequent Phenomena. Report of the Krakatoa Committee of the Royal Society. Trubner and Co., London.

Tatsumi, Y. (1986). Formation of the volcanic front in subduction zones. Geophysical Research Letters, 13(8), 717-720

Tatsumi, Y., Sakuyama, H., Fukuyama, H., Kushiro, I. (1983).Generation of arc basalt and thermal structure of the mantle wedge in subduction zones. Journal of Geophysical Research, 88, pp. 5815-5825.

Taylor, S.R. (1967). The origin and growth of continents. Tectonophysics, 4(1), 17-34 
Topping, W.W. (1973). Tephrostratigraphy and Chronology of Late Quaternary eruptives from Tongariro Volcanic Centre, New Zealand. New Zealand Journal of Geology and Geophysics, 16(3), 397-423

Turner, S.P., George, R.M.M., Evans, P.J., Hawkesworth, C.J. \& Zellmer, G.F. (2000). Time-scales of magma formation, ascent and storage beneath subduction-zone volcanoes. Philosophical Transactions of the Royal Society of London, 358, 1443-1464

Tsuchiyama, A. (1985). Dissolution kinetics of plagioclase in the melt of the system diopside-albite-anorthite, and origin of dusty plagioclase in andesites. Contributions to Mineralogy and Petrology, 89, 1-16

Vance, J.A., (1965). Zoning in Igneous Plagioclase: Patchy Zoning. The Journal of Geology, Vol. 73(4), pp. 636-651

Viccarro, M., Giacomoni, P.P., Ferlito, C., Cristofolini, R. (2009). Dynamics of magma supply at Mt. Etna volcano (Southern Italy) as revealed by textural and compositional features of plagioclase phenocrysts. Lithos, 116, 77-91

Watson, E.B. \& Baxter, E.F. (2007). Diffusion in solid-Earth systems. Earth and Planetary Science Letters, 253, 307-327

Wilson, M. (1989). Igneous Petrogenesis. Unwin Hyman, London.

Wilson, C.J.N., Houghton, B.F., McWilliams, M.O., Lanphere, M.A., Weaver, S.D. \& Briggs, R.M. (1995). Volcanic and structural evolution of Taupo Volcanic Zone, New Zealand: a review. Journal of Volcanology and Geothermal Research, 68, $1-28$

Wilson, C. J. N., Blake, S. Charlier, B. L. A. and Sutton, A. N. (2006). The 26.5 ka Oruanui Eruption, Taupo Volcano, New Zealand: Development, Characteristics and Evacuation of a Large Rhyolitic Magma Body. Journal Of Petrology, 47(1) 35-69

Zajacz, Z. \& Halter, W. (2007). LA-ICPMS analyses of silicate melt inclusions in coprecipitated minerals: Quantification, data analysis and mineral $/$ melt partitioning. Geochimica et Cosmochimica Acta, 71, pp. 1021-1040

Zellmer, G.F., Blake, S., Vance, D., Hawkesworth, C. \& Turner, S. (1999). Plagioclase residence times at two island arc volcanoes (Kameni Islands, Santorini, and Soufriere, St. Vincent) determined by Sr diffusion systematics. Contributions to Mineralogy and Petrology, 136, 345-357 